Florida International University FIU Digital Commons

FIU Electronic Theses and Dissertations

University Graduate School

7-8-2016

\title{
Medicinal Plants of Trinidad and Tobago: Selection of Antidiabetic Remedies
}

Angelle L. Bullard-Roberts

Florida International University, abullo05@fiu.edu

DOI: $10.25148 /$ etd.FIDC000775

Follow this and additional works at: https://digitalcommons.fiu.edu/etd

Part of the Alternative and Complementary Medicine Commons, Biology Commons, Botany Commons, and the Nutritional and Metabolic Diseases Commons

\section{Recommended Citation}

Bullard-Roberts, Angelle L., "Medicinal Plants of Trinidad and Tobago: Selection of Antidiabetic Remedies" (2016). FIU Electronic Theses and Dissertations. 2546.

https://digitalcommons.fiu.edu/etd/2546

This work is brought to you for free and open access by the University Graduate School at FIU Digital Commons. It has been accepted for inclusion in FIU Electronic Theses and Dissertations by an authorized administrator of FIU Digital Commons. For more information, please contact dcc@fiu.edu. 


\section{FLORIDA INTERNATIONAL UNIVERSITY}

Miami, Florida

\section{MEDICINAL PLANTS OF TRINIDAD AND TOBAGO: SELECTION OF ANTIDIABETIC REMEDIES}

A dissertation submitted in partial fulfillment of the requirements for the degree of DOCTOR OF PHILOSOPHY

in

\section{BIOLOGY}

by

Angelle L. Bullard-Roberts 
To: Dean Michael R. Heithaus

College of Arts, Sciences and Education

This dissertation, written by Angelle L. Bullard-Roberts and entitled Medicinal Plants of Trinidad and Tobago: Selection of Antidiabetic Remedies, having been approved in respect to style and intellectual content, is referred to you for judgment.

We have read this dissertation and recommend that it be approved.

Suzanne Koptur

Jennifer Richards

J. Martin Quirke

Maria Fadiman

Bradley C. Bennett, Major Professor

Date of Defense: July 8, 2016

The dissertation of Angelle L. Bullard-Roberts is approved.

Dean Michael R. Heithaus

College of Arts, Sciences and Education

Andrés G. Gil

Vice President for Research and Economic Development and Dean of the University Graduate School

Florida International University, 2016 
(C) Copyright 2016 by Angelle L. Bullard-Roberts

All rights reserved. 


\section{DEDICATION}

I dedicate this dissertation to my mother, Arline B. Andrews-Bullard (28 04»1945 16 07 2015) who introduced me to Ethnobotany without even knowing it! Visits to family and friends became plant collection field trips that produced a veritable Garden of Eden in our backyard. Episodes of accident or illness among her five offspring became testing grounds for many natural remedies which she had read about in her health and recipe book collection. Then in her role as manager of our family-owned health-food store, that knowledge that she had gathered from field and literature was imparted to anyone who would listen. Though I did not inherit Mommy's gifts of fecundity, I earnestly hope to leave an indelible mark in the lives of T\&T's people with my medicinal plant research. 


\section{ACKNOWLEDGMENTS}

So many to thank, so few pages...

Thanks be to God, for life and a measure of health and mental fortitude to finally see this moment.

Thanks to my major professor, Dr. Bradley C. Bennett for sticking with me to the last word and to my committee members, Dr. Koptur, Dr. Richards, Dr. Quirke and Dr. Fadiman who were always gracious, helpful, and hopeful (sometimes more so than I) to get me to this point.

Thanks to the funding agencies that supported my field and lab work: the FIU Graduate School - DEA Fellowship; the Garden Club of America - Anne Chatham Medicinal Botany Fellowship; the Kelly Foundation Scholarship Fund for Tropical Botany and the South Florida Chapter of the Explorer's Club.

Thanks to my Ethnobotany sisters, Cassy Quave and Janna Rose, for making the path smoother and to the Koptur lab for adopting me when I had no lab family left.

Thanks to Sasha, Asha and Xtina from the Jaffe and Berry Labs at BBC for sharing their space, equipment and expertise.

Thanks to James and Kate at the Quave Lab at Emory University for helping me to navigate through failed trials and strange calculations.

Thanks to my Biology colleagues and fellow TAs through the years, who gave books or reagents, switched teaching sections, shared life stories and generally made me feel more human through the process: Adriana, Alberto, Alina, Amy, Anya, Beyte, Boris, Evonne, Danielle, Ian, Jose, Kristie, Lilly, Lorenzo, Marby, Marcy, Monica, Nicole, Nikeisha, Roberto, Roxaneh, Sylvia, Tanya, Vanessa, Vivian, \& Yadira. 
Thanks to the FIU Trini Bio crew who went before, Bryan, Liz and Nicole - It's about time! Ent?!

Thanks to the FIU Biology staff—-the friendliest office on campus! To: Helen, Eliana, Alex, Wilma, (also Erin, Ileana and Tony from the Bio Grad office), for helping make light of paperwork requirements.

Thanks to colleagues and students of the Biology Department at the University of the Southern Caribbean for treating me as if I'd never left and for bending over backward to make my research in T\&T a success: Cams, Dav, Denise, Clairene, Dr. Scobie, Dr. Antwi, Mr. Lawrence, Camille \& the Lab Techs. Special thanks to Mr. Anthony Brumble for his enthusiasm and interest in helping me with my first round of fieldwork. Thanks also to the faculty, staff and administration of USC for access to facilities and space.

Thanks to each Trinbagonian—-from Charlotteville to Signal Hill, Scarborough to Roxborough, Bon Accord to Delaford, Paramin to Point Fortin, Moruga to Cumana, Sangre Grande to Petit Valley, Toco to Sando and everywhere in between-who spent even 1 minute telling me what you know about T\&T plants. Special thanks to herbalists, Clarence Charles and Francis Morean for the personal interest they took in my project and for going with me on remote plant collection trips.

Thanks to my friends and extended family in T\&T who opened their homes and hearts, gave up their bed, kept me fed, helped me find tanties and grannies, translated Trini interviews, and even went "on D road" with me! To: Angie \& Calvin, Bebe \& Selwyn, Cams \& Mom Nunes, Candy \& Eldon, Candy B, Aunty Carol, Cassy B, Cheryl \& Anthony, Cleo \&Vishnu, Clinton P., Daddy \& Joan, Dav \& Moms, Uncle George, 
Heather \& Chad, Jerome and Donna, Judymae \& Mom, Kami \& Calvin, Kathy, Uncle Kenneth, Kevon, Louis, Manda-Panda \& Andre, and anyone I may have missed, a million THANK YOUS!

Thanks to my church families, who succored me through many stresses, with their prayers and tears, room and board, packing and moving, calling and texting, soups and smoothies and so much more! Special thanks to my church siblings, (you know who you are), who stayed in touch through overnight Miami to Tally trips, held my hand through emergency hospitalizations and surgeries and loved me through the loss of my Mom...you gave more than I could ever ask for, more than I could ever repay.

To my sisters, Leanie, Vernie and Av and my niece, Ariselle: thanks for always being positive and for reminding me of where I've come from, where I'm going and why this matters.

To my brother, Al: thanks for blindly throwing your means behind me so I could focus on finishing. I have no idea why you kept on believing that I could do it, but I'm surely glad you did.

To my husband, Ronnie, fellow dissertator, best (and worst) critic, pillow-talk buddy, bouncer-offer-of-ideas: I cannot imagine how I would have gotten to this point without you to listen to my fears, be my voice of reason, AND to do all the shopping! I'm so glad for your patience and empathy even when you did not understand! This achievement is as much yours as it is mine!

Finally, again, THANKS BE TO GOD, with whom NOTHING shall be IMPOSSIBLE! Luke 1:37 


\title{
ABSTRACT OF THE DISSERTATION \\ MEDICINAL PLANTS OF TRINIDAD AND TOBAGO: \\ SELECTION OF ANTIDIABETIC REMEDIES
}

\author{
by
}

Angelle L. Bullard-Roberts

Florida International University, 2016

Miami, Florida

\section{Professor Bradley C. Bennett, Major Professor}

Diabetes mellitus (DM) is a group of non-infectious diseases that cause hyperglycemia. DM symptoms were first clinically described by ancient Greek physicians whose prescriptions included plant-based remedies. Today, DM affects $>400$ million people globally and prevalence rates are rapidly increasing in developing countries where basic healthcare relies on local knowledge of botanical remedies. Many developing countries are home to diverse peoples and plants_-providing fodder for varied plant-selection strategies and unique botanical pharmacopoeias.

I addressed the plant-selection strategies used in a multi-ethnic, developing country, Trinidad and Tobago (T\&T), to ascertain their role in shaping the local antidiabetic pharmacopoeia and to assess their benefits and risks in identifying safe and useful remedies. Using literature reviews, field surveys, and laboratory bioassays, I completed three categories of analysis.

Ethnobotanical analyses showed that T\&T's antidiabetic pharmacopoeia is primarily of recent origin as $>50 \%$ of the 48 historical DM remedies were Neotropical natives, including congenerics of well-known medicinal Paleotropical genera. 
Nevertheless, conservative knowledge transmission was also evident as several Paleotropical species of T\&T's pharmacopoeia, including Momordica charantia and Catharanthus roseus were also used in Africa, India and across the Caribbean.

Paleotropical natives with a long history of use are likely to be safer remedies. Ethno-medicinal analyses of the pre- and post-2000 DM remedies of T\&T, totaling 99 species, suggest that the centuries-old hot/cold folk disease-model was the model predominantly used in plant-selection. Parallels found between T\&T folk concepts and biomedical mechanisms of DM provide probable bases for efficacy but the chronic use of purgatives and bitter-tasting plants is likely to be risky.

Phytochemical analyses revealed that $69 \%$ of the tested plant extracts contained phenolic compounds, with more than half producing $>80 \%$ alpha-glucosidase inhibition. Phenolic content and alpha-glucosidase inhibition were strongly correlated among food plants used as medicines, suggesting higher probability of selection as a result of nontarget effects. The medicinal use of food plants may provide the best margins of safety and efficacy in identifying antidiabetic remedies.

Together, these analyses showed how culture-specific plant-selection strategies can identify safe, useful remedies for developing countries to address their increasing DM prevalence in a cost-effective and sustainable manner. 


\section{TABLE OF CONTENTS}

CHAPTER

PAGE

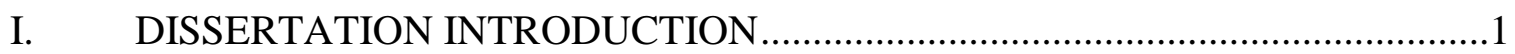

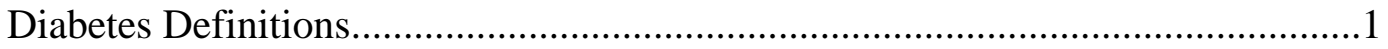

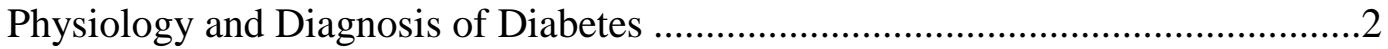

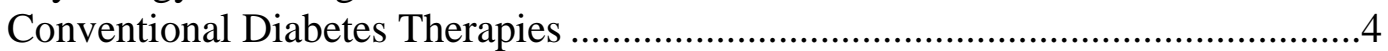

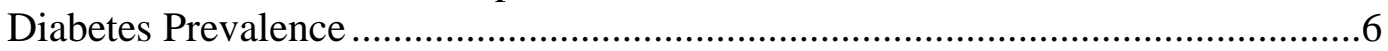

Diabetes Mellitus and Botanical Remedies ..........................................................

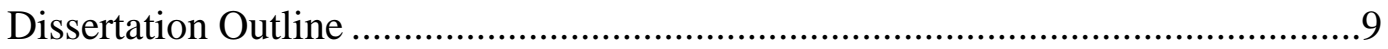

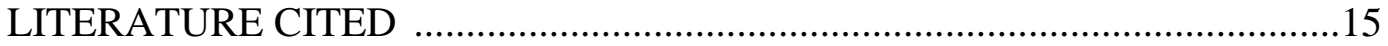

II. HISTORICAL ETHNOBOTANY AND KNOWLEDGE TRANSMISSION

OF DIABETES REMEDIES IN A MULTI-ETHNIC SOCIETY ……................18

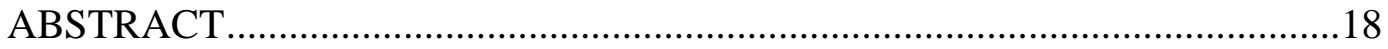

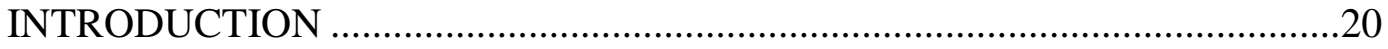

Historical Overview of Diabetes Mellitus ...............................................20

Diabetes Mellitus and Botanical Remedies .............................................21

Background - Country Profile .................................................................22

Background - Plant Selection Theory ………………………………...26

Knowledge Transmission............................................................26

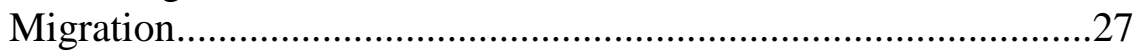

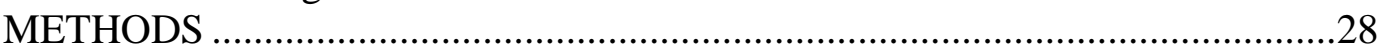

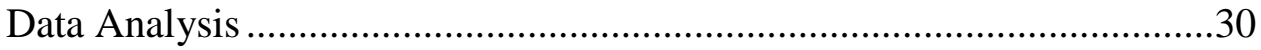

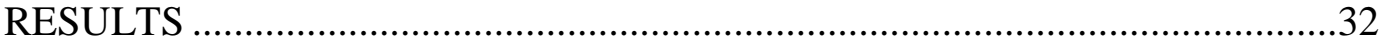

Trinidad and Tobago's Antidiabetic Plants ...............................................32

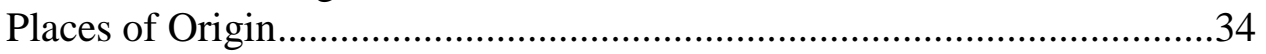

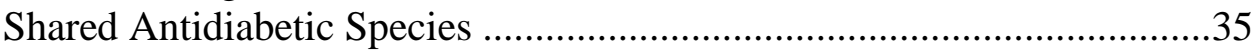

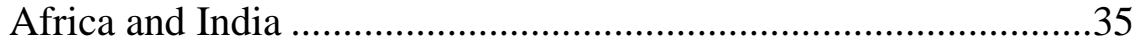

Caribbean Basin .......................................................................36

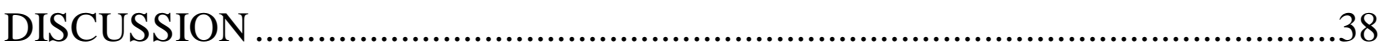

Trinidad and Tobago's Antidiabetic Plants ..............................................38

Knowledge Transmission...........................................................................

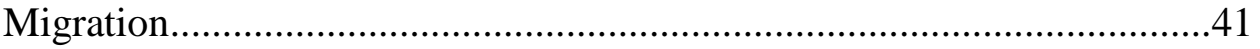

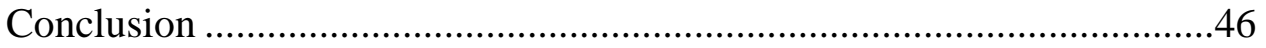

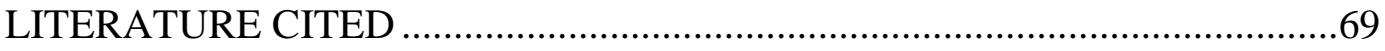

III. THE FOLK DISEASE CONCEPTION OF DIABETES MELLITUS

AND ITS REMEDIES IN TRINIDAD AND TOBAGO ……...........................78

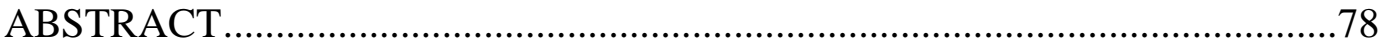

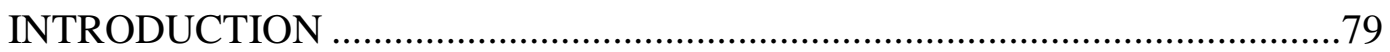

Background - Folk Disease Concepts ....................................................81

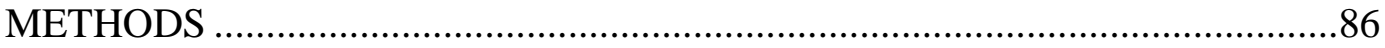




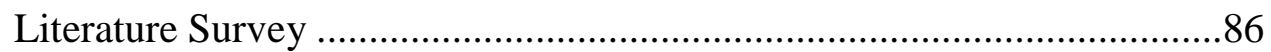

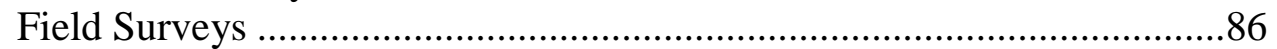

Antidiabetic Remedies ........................................................................ 88

Folk Disease Concepts in Field and Literature Analysis ............................89

Social Network Analysis..................................................................90

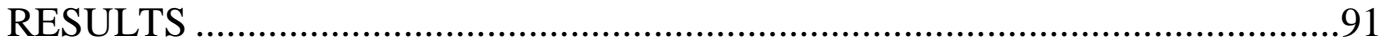

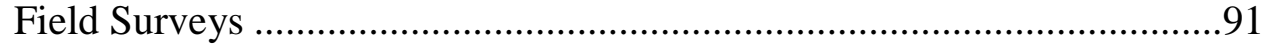

Antidiabetic Remedies .........................................................................92

Folk Disease Concepts in Field and Literature Analysis ............................93

Emerging Disease Concepts ................................................................94

Opposite Disease Concepts..................................................................96

Social Network Analysis....................................................................97

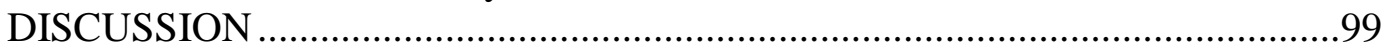

Trinidad and Tobago's Antidiabetic Remedies .......................................99

Folk Disease Concepts ........................................................................101

Prevailing Disease Concepts......................................................101

Emerging Disease Concepts ......................................................102

Opposite Disease Concepts.........................................................103

Parallels in Folk Disease Concepts and Biomedical Mechanisms

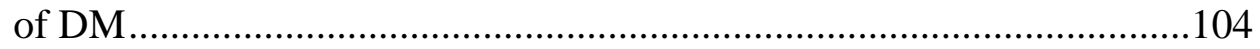

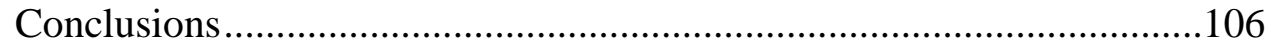

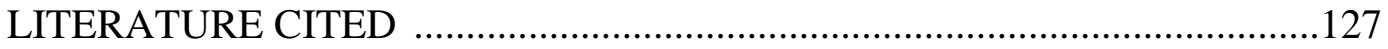

IV. A PHYTOCHEMICAL BASIS FOR ANTIDIABETIC PLANT

SELECTION IN TRINIDAD AND TOBAGO .............................................133

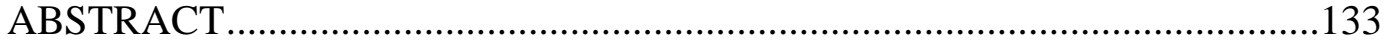

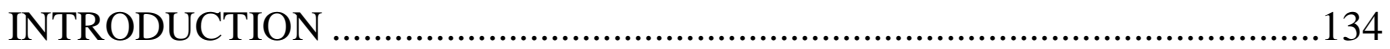

Plant Phenolic Compounds ....................................................................135

Digestive Enzyme Inhibition as Antidiabetic Action ...............................137

Non-Target Antidiabetic Effects of Medicinal Food Plants ....................139

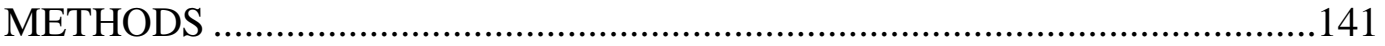

Selected Plants and Plant Preparation.....................................................141

Total Phenolic Content .......................................................................142

Alpha-Glucosidase Inhibition Assay ......................................................143

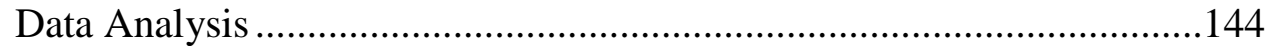

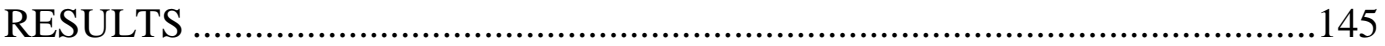

Plant Categories, Characteristics and Yields ...........................................145

Total Phenolic Content and Percentage Enzyme Inhibition ......................146

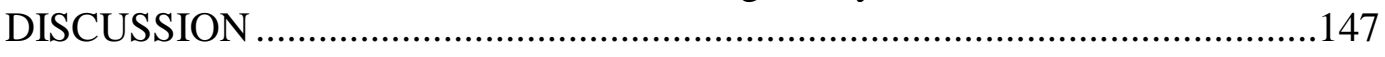

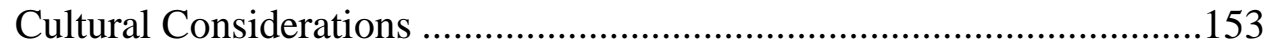

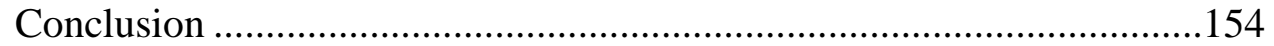

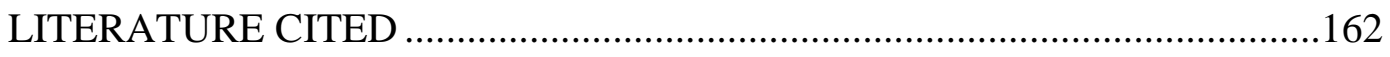

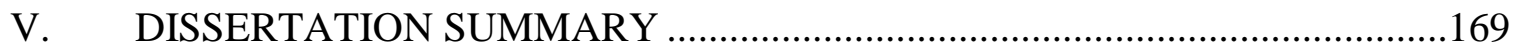

Summative Argument ..................................................................................169 
Chapter Summaries \& Risk-Benefit Analysis ................................................170

Historical/Cultural Knowledge ......................................................171

Folk Disease Concepts ......................................................................173

Medicinal Use of Food Plants (Non-Target Effects) ...........................175

Study Limitations and Future Work ...........................................................176

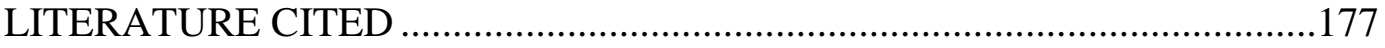

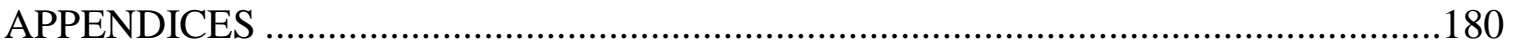

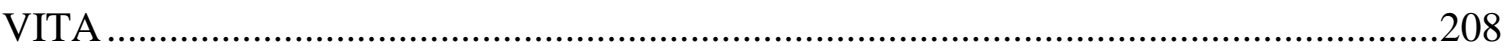




\section{LIST OF TABLES}

TABLE

PAGE

\section{CHAPTER II}

Table 1 Plants historically used as antidiabetics in Trinidad and Tobago

Table 2 Countries or Regions on African continent from which slaves arrived in Trinidad and Tobago with corresponding list of current names.

Table 3 Regions of the Indian sub-continent from which indentured laborers

were sourced with corresponding list of recent (1981) names .58

Table 4 Trinidad and Tobago antidiabetics shared with western Africa

Table 5 Trinidad and Tobago antidiabetics shared with India

Table 6 Trinidad and Tobago antidiabetic species/genera shared with Caribbean Basin countries/regions

Table 7 Antidiabetic Species Similarity Indices for Caribbean Basin

locations in relation to Trinidad and Tobago

\section{CHAPTER III}

Table 1 List of 99 plants indicated as diabetes remedies in Trinidad and Tobago from literature and field surveys

Table 2 Most commonly cited antidiabetic plants of Trinidad and Tobago from post-2000 literature and field surveys

\section{CHAPTER IV}

Table 1 Plant extraction method and percentage yield of 16 antidiabetic plants from Trinidad and Tobago

Table 2 Correlation coefficients ( $\mathrm{r}^{2}$ values) of Alpha-glucosidase inhibition (AGI) and Total Phenolic content (TPC) for tested plant extracts by subgroup. .161 


\section{LIST OF FIGURES}

FIGURE

PAGE

\section{CHAPTER I}

Figure 1 The Main Types and Stages of Diabetes as recognized by the American Diabetes Association (CADA 2014)

Figure 2 Main categories of oral Type 2 DM drugs and their effects on organ sites involved in glucose metabolism (c) CMAJ 2005

Figure 3 Comparison of global estimates of Diabetes incidence among adults from low- (LIC), lower-middle- (LMIC), upper-middle (UMIC) and high income countries (HIC) for 2011 (lower level) and 2030 (upper level). Elsevier (C 2011 DOI: (10.1016/j.diabres.2011.10.029) ...13

\section{CHAPTER II}

Figure 1 Map of the Caribbean Basin showing Trinidad and Tobago (in red box)

Figure 2 Modern political map of African continent showing West African countries (in red) from which slaves were conscripted and sent to Trinidad and Tobago.

Figure $3 \quad$ Map of India showing location of countries, states and cities of interest with dated (1981) names

Figure 4 Social Network Analysis (SNA) graph of shared antidiabetic genera of the Caribbean Basin.

Figure 5 Social Network Analysis (SNA) graph of shared antidiabetic genera of the Caribbean Basin showing language groupings.

Figure 6 Social Network Analysis (SNA) graph of shared antidiabetic genera of the Caribbean Basin showing locality groupings. .68

\section{CHAPTER III}

Figure 1 Model of relationship between four bodily humors and the primary qualities of matter as represented in the Hippocratic writing - "On the nature of Man"

Figure 2 Social Network Analysis (SNA) graph showing connectivity between three disease concepts and antidiabetic plants (Pre-2000 Literature). 
Figure 3 Social Network Analysis (SNA) graph showing connectivity between three disease concepts and plants (Post -2000

Literature \& Field Data).

Figure 4 Social Network Analysis (SNA) graph showing connectivity between five disease concepts and antidiabetic plants (Pre-2000 Literature)

Figure 5 Social Network Analysis (SNA) graph showing connectivity between five disease concepts and antidiabetic plants (Post-2000 Literature \& Field Data).

Figure 6 Social Network Analysis (SNA) graph showing connectivity between contrasting hot vs cold concepts and antidiabetic plants (Pre-2000 Literature)

Figure $7 \quad$ Social Network Analysis (SNA) graph showing connectivity between contrasting hot vs cold concepts and antidiabetic plants (Post-2000 Literature \& Field Surveys)

\section{CHAPTER IV}

Figure 1 Structural models of polyhydroxy compounds: a disaccharide (maltose) and a phenolic compound (quercetin), showing presence of ringed structure and $-\mathrm{OH}$ groups 156

Figure 2 Total Phenolic Content and Alpha-glucosidase inhibition of 16 antidiabetic plant extracts from Trinidad and Tobago.

Figure 3 Relationship between Total Phenolic Content (TPC) and Alphaglucosidase inhibitory (AGI) activity of 16 selected plants from Trinidad and Tobago

Figure 4 Relationship between Total Phenolic Content (TPC) and Alphaglucosidase inhibitory (AGI) activity of selected food plants of Trinidad and Tobago (T\&T)

Figure 5 Relationship between Total Phenolic Content (TPC) and Alphaglucosidase inhibitory (AGI) activity of selected non-food plants of Trinidad and Tobago (T\&T) 


\section{CHAPTER I}

\section{DISSERTATION INTRODUCTION}

One in every eleven adults on planet Earth has Diabetes mellitus (International Diabetes Federation [IDF] 2015). There are different manifestations of the disease and numerous therapeutic drugs used to treat them. However, prevalence rates are rapidly increasing - especially in developing countries where access to modern healthcare is limited and people still rely on botanical remedies (IDF 2015; World Health Organization [WHO] 2002).

The research for this dissertation centered around the traditional botanical remedies used to treat symptoms of diabetes mellitus (DM) in a developing country, Trinidad and Tobago (T\&T). My objectives were to identify the plant selection strategies used to generate the local antidiabetic pharmacopeia and to highlight the risks and benefits of each selection strategy. In developing countries where botanical medicine is an important means of healthcare, the increasing prevalence of DM warrants efforts to identify safe and reliable remedies that are also culturally relevant.

\section{Diabetes Definitions}

Diabetes mellitus (DM) is a group of chronic, non-communicable diseases characterized by high blood glucose levels (hyperglycemia) with common symptoms including polydipsia (excessive thirst) and polyuria (frequent urination), and, in some cases, blurred vision and polyphagia (frequent hunger) (American Diabetes Association [ADA] 2014; Baynes 2006; Centers for Disease Prevention and Control [CDC] 2014). If 
left untreated, the diabetic individual may die from dehydration or (keto) acidosis (Bennett and Knowler 2005). Poor blood glucose control can also have serious chronic consequences, including, kidney failure, limb amputation, blindness, and increased risk of stroke or heart attack (American Diabetes Association [ADA] 2014; Baynes 2006; Bennett and Knowler 2005; Centers for Disease Prevention and Control [CDC] 2014).

Although there are many manifestations of DM, three main categories are generally recognized: Type I, in which hyperglycemia results from deficient production of insulin (the hormone responsible for controlling blood glucose levels); Type II, in which hyperglycemia is associated with insulin resistance - the reduced ability of target cells (e.g., muscle and fat cells) to respond to insulin signaling - and Gestational Diabetes which is characterized by the onset of hyperglycemia during pregnancy (ADA 2014, CDC 2014; WHO 2006).

Physiology and Diagnosis of Diabetes

The control of glucose in the blood is an important homeostatic function that is maintained by the action of two hormones produced in the islets of Langerhans of the human pancreas: (a) insulin, produced by the beta cells; and (b) glucagon produced by the alpha cells. Insulin is responsible for ensuring that the glucose obtained from food is transported to the cells for storage or immediate use, while glucagon is responsible for accessing and releasing glucose stored in the liver in times of increased demand or low food availability (Baynes 2006).

Normo-glycemic individuals have tight feedback loops by which insulin responds to increasing blood glucose levels, triggering cellular signal cascades that cause receptor 
proteins in target cells—such as liver, muscle, and fat cells (adipocytes) — to uptake glucose from the bloodstream. Individuals with impaired glucose metabolism either do not produce sufficient insulin or have malfunctions in their signaling pathway so that, even when insulin is produced, the target cells do not receive signals to uptake the glucose from the blood (Baynes 2006).

As for glucagon, in normo-glycemic individuals, the fasting state or increased physical activity that draws down glucose concentration in the blood triggers glucagon release from the pancreas. Glucagon then stimulates either liver cells to convert stored glycogen into glucose (glycogenolysis) or fat and muscle cells to convert stored fats or proteins into glucose (gluconeogenesis). Under these circumstances, insulin also plays a role in ensuring that the concentration of glucose in the blood does not become too high by triggering signal cascades that can stop glycogenolysis in the liver. For the diabetic individual, one cause of hyperglycemia is a lack of control by insulin. The lack of control may occur in the absence of food intake or with food consumption and is referred to as impaired fasting glucose — a measure used in diagnosing diabetes (Baynes 2006).

Diabetes can be diagnosed using different laboratory measures including: glycated hemoglobin levels (HbA1c), fasting plasma glucose (FPG), and 2-hour plasma glucose (2-h PG) test. Of these three, the World Health Organization and the International Diabetes Federation do not recommend the use of the HbA1c for diagnosis but the American Diabetes Association does. Nevertheless, there are recognized standards for the ranges of plasma glucose levels used to diagnose diabetes and prediabetes (ADA 2014; International Diabetes Federation [IDF] 2015; WHO 2006). 
Individuals with diabetes or who are at-risk for developing diabetes are often unaware of their condition. Diagnosis may result from the observation of abnormal blood glucose levels in routine blood tests or the recognition of several risk factors during hospital admissions for unrelated conditions. Such persons are recommended for followup tests such as an oral glucose tolerance test (OGTT) to provide the 2-hour plasma glucose measure. If the levels of hyperglycemia are above normal but do not reach the levels required for a diabetic diagnosis, then those individuals are said to be pre-diabetic, which describes either of two stages: Impaired Fasting Glucose (IFG) or Impaired Glucose Tolerance (Figure 1) (ADA 2014; IDF 2015; WHO 2006).

Distinguishing Type 1 and Type II diabetes is often dependent on the age and body mass index (BMI) of the individual. Tests for antibodies in the pancreas can indicate the possibility of an autoimmune disease process and the likelihood (usually in children and adolescents) that the manifestation of diabetes is Type I. Adults (over 21) and individuals presenting with obesity are most often diagnosed as Type II diabetics (ADA 2014, Bennett and Knowler, 2005).

\section{Conventional Diabetes Therapies}

There are several diabetic therapies that are currently in use to address different aspects of metabolic function. Therapies also vary depending on the type of diabetes with which an individual has been diagnosed.

For Type I diabetes, the primary treatment is the administration of insulin because, in most cases, the beta cells in the individual's pancreas were destroyed by autoimmune disease processes and, therefore, are incapable of producing sufficient insulin 
quantities (Baynes 2006, Seino et al. 2010). Other therapies for Type I DM have included whole organ (pancreas) transplants since 1966 or more recently pancreatic islet transplants (Girman and Saudek 2011 and Qi 2014).

Type II diabetes mellitus (T2DM) is more complex because the disease etiology is often unclear, though most diagnosed cases are associated with insulin resistance (Lebovitz 1999). As it is also associated with a range of related symptoms, including cardiovascular disease and obesity, T2DM had been considered to be early manifestation of Syndrome X—now called Metabolic Syndrome — that is characterized by various aspects of cardiovascular disease (Sadikot and Misra 2007; Zimmet, et al. 2001). Nevertheless, most national and international bodies now recognize T2DM as a separate, though related, condition (Halcox and Misra 2015).

Patients with T2DM usually do not require insulin supplementation, as their pancreatic beta cells are still functional (Baynes 2006). Advances in unravelling the physiological mechanisms of glucose metabolism from the 1950s to the 1990s have identified oral antidiabetic drugs that can target the various organs of the body which are involved in maintaining glucose homeostasis (Figure 2) (Barnett and Krall 2005). The modes of action of these drugs involve, inter alia: reducing gluconeogenesis in the liver (e.g., biguanides); reducing lipolysis in adipose tissue (e.g., thiazolidinediones); increasing glycogenesis in muscle cells (e.g., thiazolidinediones and biguanides); reducing the rate of glucose digestion in the intestines (e.g., alpha-glucosidase inhibitors); or increasing the rate of insulin secretion from the pancreas (e.g., sulfonylureas) (Baynes 2006; Cheng and Fantus 2005). 
Since the turn of the 21 st century, some newer antidiabetic drugs have been designed to specifically target key molecules involved in glucose metabolism. Examples include: the incretin agonist, exenatide, that promotes the transcription of glucagon-like peptide -1 (GLP-1), which triggers insulin secretion in the presence of high glucose concentrations; and the dipeptidyl-peptidase IV (DPP-IV) enzyme inhibitor, sitagliptin, that prevents DPP-IV from deactivating incretins like GLP-1, thereby sustaining insulin secretion over longer periods (Gallwitz in Schwanstecher 2011; Matthaei, et al. 2009).

Although individuals with diabetes, especially Type I diabetes, are likely to live longer today as a result of the many available therapies, their overall life expectancy is still lower than the general population by as many as 15 years (Lasker et al. 2010). Also, diabetes patients' quality of life is reduced by the number of hospital visits and stays relating to kidney disease, limb amputations and vision loss, and their out-of-pocket costs for medications and supplies, which averaged around \$4000 in 2012 (ADA 2013).

In the US in 2012, 246,000 people died as a result of diabetes or its comorbidities. Furthermore, $55 \%$ of all deaths from renal failure, $28 \%$ of all cerebrovascular-associated deaths (stroke), and 16\% of all cardiovascular associated deaths occurred in individuals with diabetes (ADA 2013). The number of persons diagnosed with diabetes in 2012 was 22.3 million or about $7 \%$ of the US population (ADA 2013). That number is expected to reach 29.6 million by 2030 (Whiting et al. 2011).

Diabetes Prevalence

On a global scale, diabetes prevalence — estimated at 151 million adults (age 2079) in 2000 - increased to 415 million in 2015 and is projected to reach 642 million in 
2040 (IDF 2000, IDF 2015). Though the countries with the largest numbers of individuals with DM are still high-income, industrialized societies, four of the top ten countries for number of people with diabetes in 2015, were middle income countries: Mexico, Egypt, Indonesia, and Bangladesh. Also, the per capita rates of prevalence of DM in developing countries, e.g., Mauritius (24.3\%), are ranked among the highest globally (IDF 2015). In the Americas, the two countries with the highest estimated DM prevalence rates are the developing countries Barbados (17.0\%) and Martinique (17.6\%) (IDF 2015). At currently predicted rates, low and middle income countries will experience the highest increases by 2030 (Whiting et al. 2011) (Figure 3).

Many low and middle income countries lack the capital, technology, and infrastructure to provide diabetes treatment options similar to those available in the US or Europe. In the face of limited resources and an already heavy demand for treating infectious diseases, that pose a more imminent threat,( e.g., HIV/AIDS), many developing countries are forced to allocate reduced funds toward the treatment of chronic conditions (IDF 2015). The primary healthcare options for $60-90 \%$ of the population in many low and middle-income countries have been traditional systems of care that use alternative remedies such as botanical medicines (WHO 2002). Research into traditional botanical remedies may therefore provide a means of addressing the increasing DM prevalence.

Diabetes Mellitus and Botanical Remedies

The notion of finding effective diabetes treatments from botanical sources is not new - at least one contemporary diabetes treatment was originally derived from a plant. 
The oral antidiabetic drug, metformin (dimethyl guanidine), functions as an insulin sensitizer, to increase the rate at which insulin binds to its receptors, thereby reducing insulin resistance. That drug is designed from the the alkaloid galegine, which was originally discovered in goat's rue, Galega officinalis L., an antidiabetic botanical remedy that was used prior to the discovery of insulin (Bailey and Day 2004).

Another group of oral antidiabetic medicines includes miglitol, voglibose, and acarbose that function as antidiabetics by reducing digestive enzyme activity in the gut. Though all three are synthesized from chemicals first discovered in bacteria, miglitol is designed from nojirimycin, a compound also produced in the root bark of the white mulberry, Morus alba L. (Ghani 2015).

Furthermore, review articles over the last two decades highlight the fact that hundreds of plant extracts and plant-based chemicals have been shown to have antidiabetic activity in both in vitro (bioassay) and in vivo (animal) diabetes experimental models (Alarcon-Aguilara et al. 1998; Bailey and Day 1989; Bnouham et al. 2006; Dham et al. 2006; Handa et al. 1989; Ivorra et al. 1989; Marles and Farnsworth 1995; Rahman and Zaman 1989; Zareba et al. 2005). Nevertheless, these findings have limited direct utility to the people in developing countries who rely on plant remedies, as these studies are primarily aimed at drug development, the cost of which is out of the reach of many of these societies. What is needed to bridge the divide between the field and the laboratory is inquiry that is focused on elucidating safety and efficacy of what Waller (1993:190) called "ethnomedical preparations". Yet, two decades hence, that prospect is still a difficult one, because there are no feasible, low-cost alternatives to the drug development 
process, with its series of rounds of laboratory testing and ultimate gold standard of the double-blind clinical trial.

Meanwhile, in developing countries, where the pace of urbanization and modernization result in behavioral and environmental changes that introduce new diseases faster than solutions can be found (Zimmet et al. 2001), botanical experimentation and native plant selection processes continue. I posit that one pathway forward is to build on the intrinsic knowledge-base that is inherent in these plant selection processes to identify the most useful, cost-effective strategy that provides reasonable measures of safety and efficacy.

\section{Dissertation Outline}

Chapter I (this chapter) provided an overview of the physiology and epidemiology of diabetes mellitus and the challenges posed by its increasing prevalence in the developing world where access to modern healthcare is limited. To meet these challenges, I suggested the potential use of local botanical remedies. In the remaining chapters, I will identify and assess the plant selection strategies used to develop the botanical antidiabetic pharmacopoeia of Trinidad and Tobago, a developing country with a high prevalence of diabetes mellitus.

In Chapter II-Historical Ethnobotany and Knowledge Transmission of Diabetes Remedies in a Multi-ethnic Society-I compared the historical remedies used for DM in Trinidad and Tobago with those from western Africa, India and the Caribbean Basin countries. As knowledge of diabetes preceded the formation of New World 
societies, this exercise was a means of elucidating the cultural and historical precedents for DM plants used in T\&T.

In Chapter III-The Folk Disease Conception of Diabetes Mellitus and its

Remedies in Trinidad and Tobago - I examined both literature and field data in search of evidence of a prevailing folk disease concept of DM, to determine its role (if any) in the selection of the most popular antidiabetic remedies in T\&T. I also compared the prevailing folk disease concepts to biomedical mechanisms of DM to identify possible parallels that might explain the popularity (and supposed efficacy) of the commonly cited remedies. DM prevalence is increasing in developing countries and may have driven people to apply long-used remedies in new ways. As such, these analyses were intended to chronicle the cultural paradigms that undergird local disease and plant classification systems.

\section{In Chapter IV—A Phytochemical Basis for Antidiabetic Plant Selection in}

Trinidad and Tobago - I investigated the potential role of non-target effects of plant phytochemicals in the selection of antidiabetic remedies using in vitro biochemical assays and correlational analyses. As cultivated food plants tend to be selectively bred for color, flavor, and scent which are often imparted by phenolic compounds, the phenolic content of a cross-section of $\mathrm{T} \& \mathrm{~T}$ antidiabetics was assessed and compared to the antidiabetic property of digestive enzyme inhibition.

The final summary chapter (V) highlights connections among the three chapters, reiterates the findings in the context of the benefits, risks and challenges of each plant selection strategy, and presents the limitations of this study. I also included suggestions of future work that can be done to address the limitations and build on the study findings. 
Figure 1 - The Main Types and Stages of Diabetes as recognized by the American Diabetes Association (C ADA 2014)

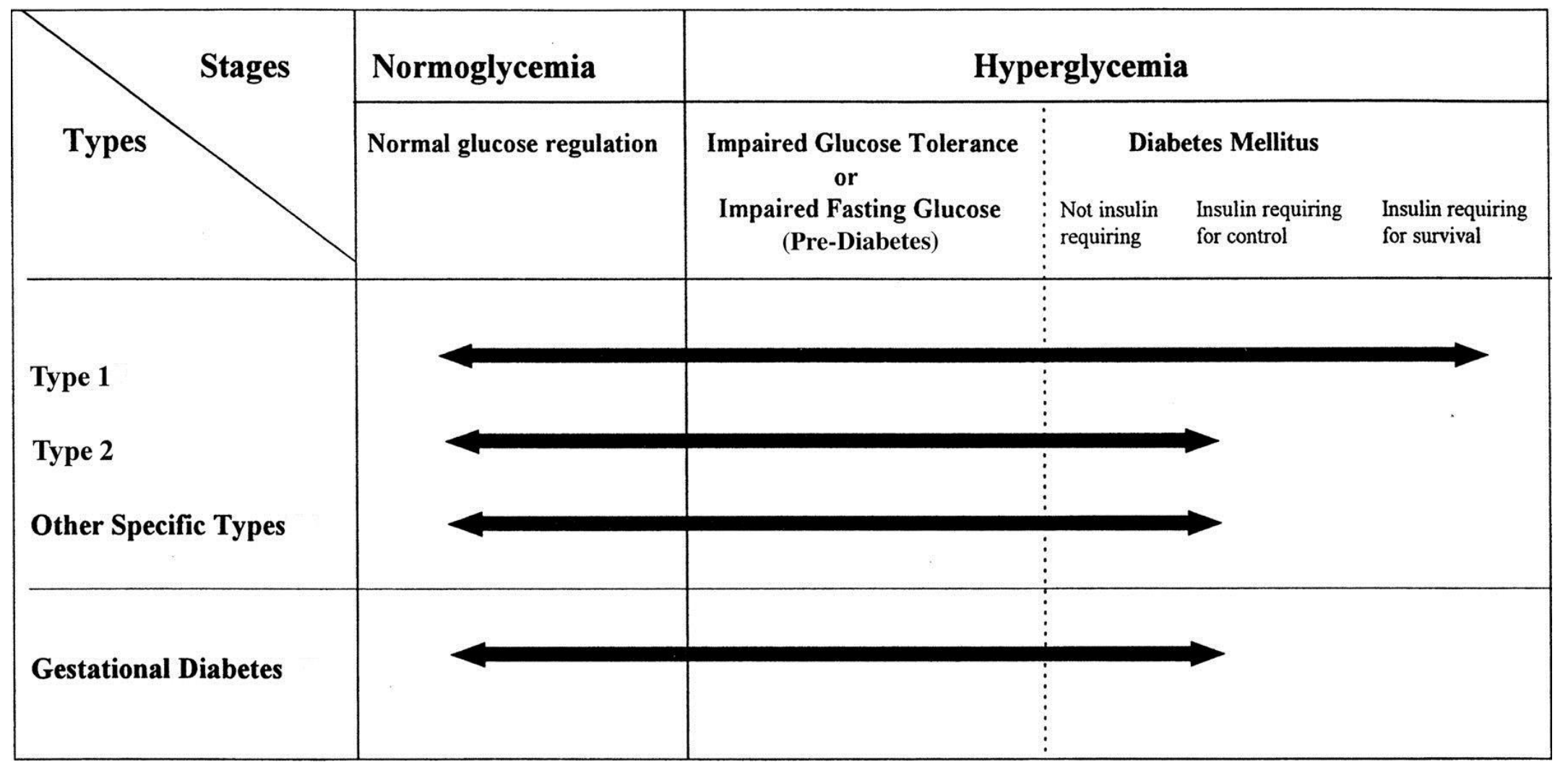

Note: Arrowheads in figure indicate the extent of the range of stages that individuals with each type of diabetes progress through.

Figure 1- Image taken from Diagnosis and Classification of Diabetes Mellitus

by American Diabetes Association, 2014, Diabetes Care Vol. 37/ Supplement 1, S81-S90. 
Figure 2 - Main categories of oral Type 2 DM drugs and their effects on organ sites involved in glucose metabolism ( 2005 CMAJ.
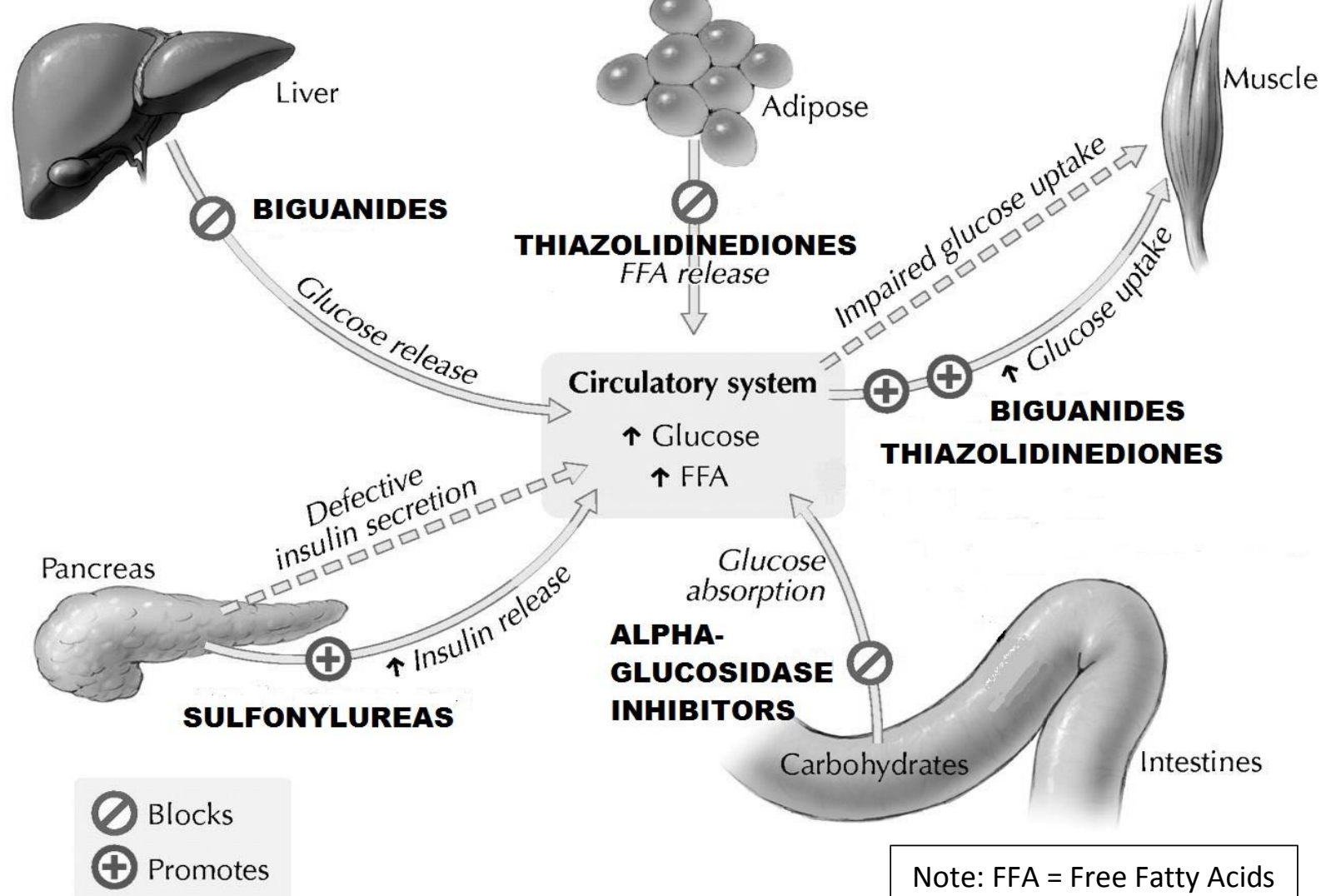

Figure 2. Adapted from "Oral antihyperglycemic therapy for type 2 diabetes mellitus" by Cheng, A.Y.Y. and I.G. Fantus, 2005, Canadian Medical Association Journal, 172/2, 213-226, (C) 2005 CMAJ. Adapted with permission from CMA. 
Figure 3 - Comparison of global estimates of Diabetes incidence among adults from low- (LIC), lower-middle- (LMIC), upper-middle (UMIC) and high income countries (HIC) for 2011 (lower level) and 2030 (upper level). Elsevier (C 2011 DOI: (10.1016/j.diabres.2011.10.029)

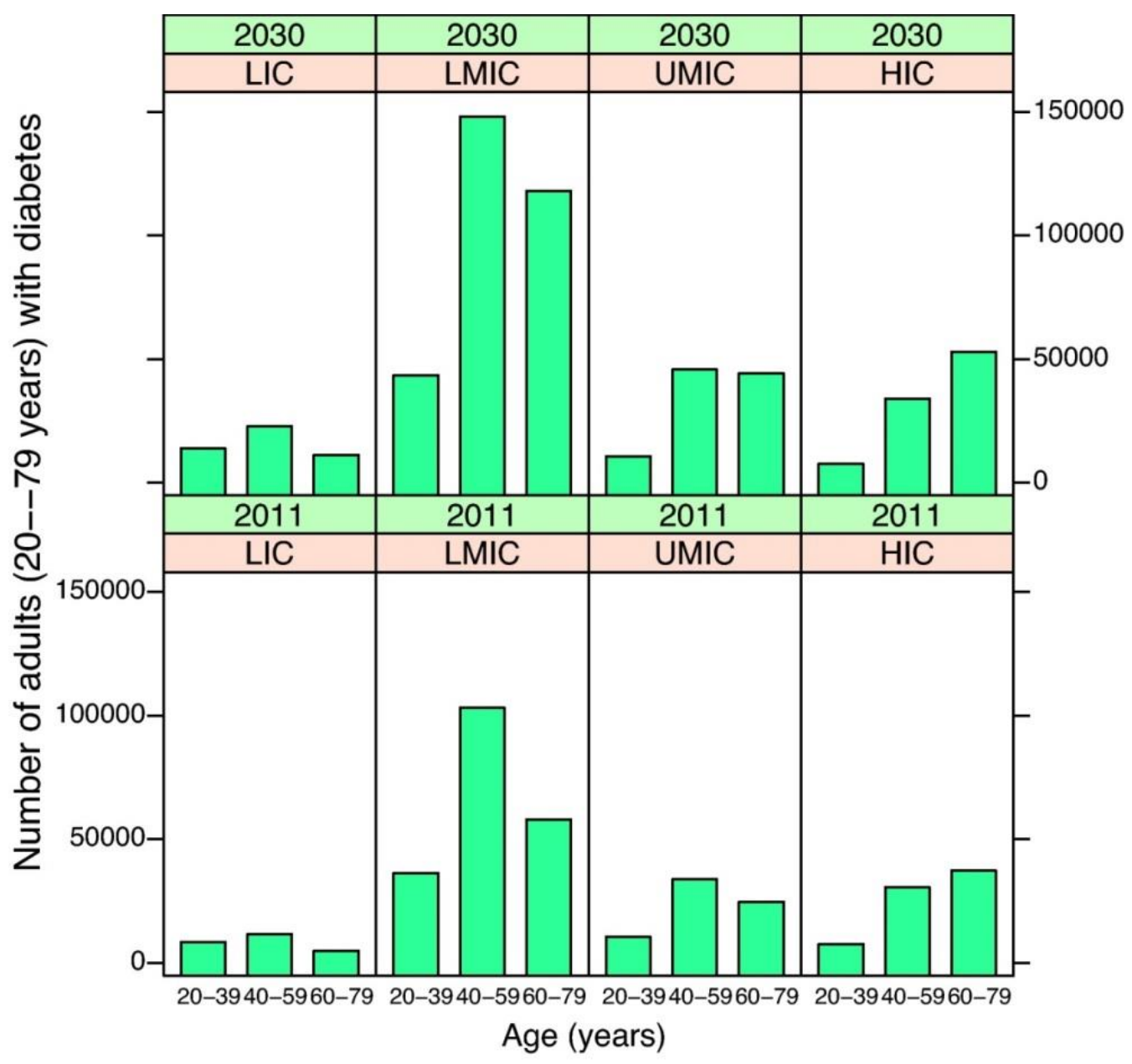

Figure 3 Reprinted from Diabetes Research and Clinical Practice, Vol 94/issue 3, David R. Whiting, Leonor Guariguata, Clara Weil, Jonathan Shaw, IDF Diabetes Atlas: Global estimates of the prevalence of diabetes for 2011 and 2030, Pages 311-321, Copyright (2011), with permission from Elsevier (See Permissions document on next page) 


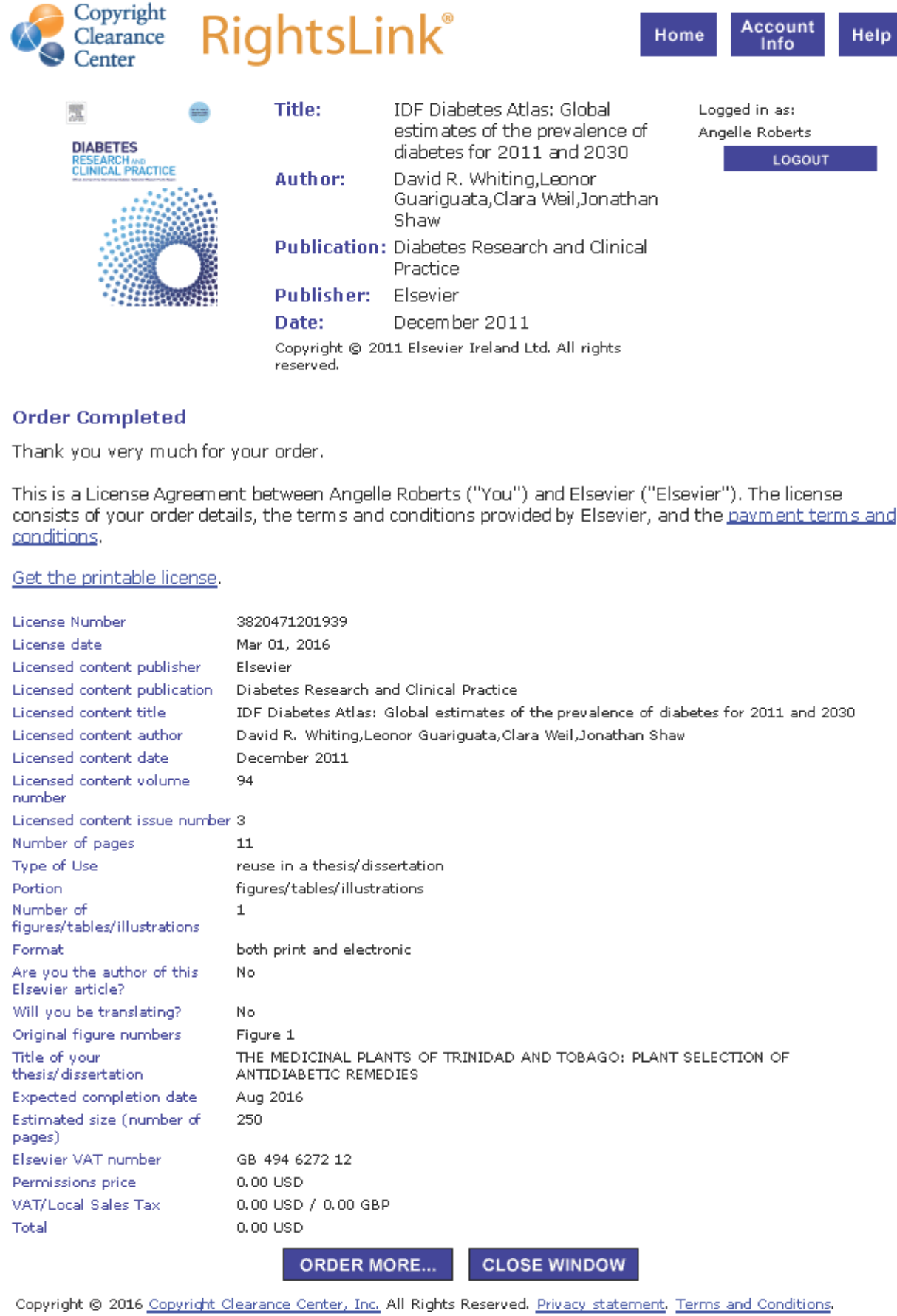

Title:

Author:

IDF Diabetes Atlas: Global estimates of the prevalence of diabetes for 2011 and 2030 Guariguata,Clara Weil,Jonathan Shaw

Publication: Diabetes Research and Clinica Practice

Publisher: Elsevier

Date: December 2011

Copyright (9) 2011 Elsevier Ireland Ltd. All rights reserved.

Logged in as:

Angelle Roberts

LOGOUT

Order Completed

Thank you very much for your order.

This is a License Agreement between Angelle Roberts ("You") and Elsevier ("Elsevier"). The license consists of your order details, the terms and conditions provided by Elsevier, and the navment terms and conditions.

Get the printable license.

License Number

3820471201939

License date Mar 01, 2016

Licensed content publisher

Licensed content publication

Licensed content title

Elsevier

Licensed content author

Licensed content date

IDF Diabetes Atlas: Global estimates of the prevalence of diabetes for 2011 and 2030

Licensed content volume David R. Whiting, Leonor Guariguata, Clara Weil,Jonathan Shaw December 2011

number

Licensed content issue number 3

Number of pages

11

Type of Use

Portion

Number of

figures/tables/illustration

Format

reuse in a thesis/dissertation

figures/tables/illustrations

Are you the author of this

Elsevier article?

Will you be translating?

Original figure numbers

Title of your

thesis/dissertation

Expected completion date

Estimated size (number of

pages)

Elsevier VAT number $\quad$ GB 494627212

Permissions price

both print and electronic

No

No

Figure 1

THE MEDICINAL PLANTS OF TRINIDAD AND TOBAGO: PLANT SELECTION OF ANTIDIABETIC REMEDIES

Aug 2016

250

0.00 USD

0.00 USD / $0.00 \mathrm{GBP}$

0.00 USD

\section{\begin{tabular}{l|l} 
ORDER MORE... & CLOSE WINDOW \\
\hline
\end{tabular}}

Copyright (9) 2016 Copyridht Clearance Center, Inc. All Rights Reserved. Privacy statement. Terms and Conditions, 


\section{LITERATURE CITED}

Alarcon-Aguilara, F.., R. Roman-Ramos, S. Perez-Gutierrez, Aguilar-Contreras, C.. Contreras-Weber, and J. Flores-Saenz. 1998. Study of the anti-hyperglycemic effect of plants used as antidiabetics. Journal of Ethnopharmacology 61:101-110.

American Diabetes Association (ADA). 2013. Economic costs of diabetes in the U.S. in 2012. Diabetes Care 36:1033-1046.

American Diabetes Association (ADA). 2014. Diagnosis and Classification of Diabetes mellitus. Diabetes Care 37:S81-S90

Bailey, C.J., and C. Day. 1989. Traditional plant medicines as treatments for diabetes. Diabetes Care 12:553-564.

Bailey, C.J., and C. Day. 2004. Metformin: Its botanical background. Practical Diabetes International 21:115-117.

Barnett, D.M and L.P. Krall. 2005. The History of Diabetes. Pages 1-17 in C. R. Kahn, G.C Weir, G.L, King, A.L. Jacobson, A.C Moses, and R.J. Smith, eds., Joslin's Diabetes Mellitus. Lippincott, Williams and Wilkins, Philadelphia, PA.

Baynes, K.C.R. 2006. Introduction to Diabetes Mellitus. Pages 1-18 in A. Soumyanath, ed., Traditional Medicines for Modern Times. CRC Press, Taylor \& Francis Group, Boca Raton, FL.

Bennett, P.H., and W.C. Knowler. 2005. Definition, Diagnosis, and Classification of Diabetes Mellitus and Glucose Homeostasis. Pages 331-339 in C. R. Kahn, G.C Weir, G.L, King, A.L. Jacobson, A.C Moses, and R.J. Smith, eds., Joslin's Diabetes Mellitus. Lippincott, Williams and Wilkins, Philadelphia, PA.

Bnouham, M., A. Ziyyat, H. Mekhfi, A. Tahri, and A. Legssyer. 2006. Medicinal plants with potential antidiabetic activity - A review of ten years of herbal medicine research (1990-2000). Int J Diabetes \& Metabolism 14:1-25.

Centers for Disease Control and Prevention (CDC). 2014. National Diabetes Statistics Report: Estimates of Diabetes and Its Burden in the United States, 2014. US Department of Health and Human Services, Atlanta GA.

Cheng, A.Y.Y., and I.G. Fantus. 2005. Oral antihyperglycemic therapy for type 2 diabetes mellitus. Canadian Medical Association Journal 172:213-226.

Dham, S., V. Shah, S. Hirsch, and M.A. Banerji. 2006. The role of complementary and alternative medicine in diabetes. Current Diabetes Reports 6:251-258. 
Gallwitz, B. 2011. GLP-1 Agonists and Dipeptidyl-Peptidase IV Inhibitors. Pages 53-74 in M. Schwanstecher ed., Diabetes - Perspectives in Drug Therapy, Springer-Verlag, Heidelberg, Germany.

Ghani, U. 2015. Re-exploring promising $\alpha$-glucosidase inhibitors for potential development into oral anti-diabetic drugs: Finding needle in the haystack. European Journal of Medicinal Chemistry 103:133-162.

Girman, P., and F. Saudek. 2011. The IKEM pancreas and islet transplant program as part of healthcare for type 1 diabetes patients: Retrospective analysis of outcome from 1983 to 2010. Review of Diabetic Studies 8:35-43.

Gulliford, M.C., D. Mahabir, and B. Rocke. 2003. Food insecurity, food choices, and body mass index in adults: Nutrition transition in Trinidad and Tobago. International Journal of Epidemiology 32:508-516.

Halcox, J., and A. Misra. 2015. Type 2 Diabetes Mellitus, Metabolic Syndrome, and Mixed Dyslipidemia: How Similar, How Different, and How to Treat? Metabolic Syndrome and Related Disorders 13:1-21.

Handa, S.S., A.S. Chawla, and Maninder. 1989. Hypoglycemic plants - A review. Fitoterapia 60:195-224.

International Diabetes Federation (IDF). 2000. IDF Diabetes Atlas, 1st edition. International Diabetes Federation, Brussels, Belgium.

International Diabetes Federation (IDF). 2015. IDF Diabetes Atlas, 7th edition. International Diabetes Federation, Brussels, Belgium.

Ivorra, M.D., M. Payá, and A. Villar. 1989. A review of natural products and plants as potential antidiabetic drugs. Journal of Ethnopharmacology 27:243-275.

Lasker, S.P., C.S. McLachlan, L. Wang, S.M.K. Ali, and H.F. Jelinek. 2010. Discovery, treatment and management of diabetes. Journal of Diabetology 1:1.

Lebovitz, H.E. 1999. Type 2 diabetes: an overview. Clinical Chemistry 45:1339-1345.

Marles, R.J., and N.R. Farnsworth. 1995. Antidiabetic plants and their active constituents. Phytomedicine 2:137-189.

Matthaei, S., R. Bierwirth, A. Fritsche, B. Gallwitz, H.U. Häring, H.G. Joost, and M. Kellerer. 2009. Medical antihyperglycaemic treatment of type 2 diabetes mellitus: Update of the evidence-based guideline of the German diabetes association. Experimental and Clinical Endocrinology and Diabetes 117:522-557.

Qi, M. 2014. Transplantation of Encapsulated Pancreatic Islets as a Treatment for Patients with Type 1 Diabetes Mellitus. Advances in medicine 2014:429710. 
Rahman, A.-U., and K. Zaman. 1989. Medicinal Plants with Hypoglycemic Activity. Journal of Ethnopharmacology 26:1-55.

Sadikot, S.M., and A. Misra. 2007. The metabolic syndrome: An exercise in utility or futility? Diabetes and Metabolic Syndrome: Clinical Research and Reviews 1:3-21.

Waller, D. 1993. Methods in Ethnopharmacology. Journal of Ethnopharmacology 38:189-195.

Whiting, D.R., L. Guariguata, C. Weil, and J. Shaw. 2011. IDF Diabetes Atlas: Global estimates of the prevalence of diabetes for 2011 and 2030. Diabetes Research and Clinical Practice 94:311-321.

World Health Organization (WHO) 2002. WHO Traditional Medicine Strategy 20022005. World Health Organization, Geneva, Switzerland.

World Health Organization (WHO). 2006. Definition and Diagnosis of Diabetes Mellitus and Intermediate Hyperglycemia: report of a WHO/IDF Consultation. World Health Organization, Geneva, Switzerland.

Zareba, G., N. Serradell, R. Castaner, S.L. Davies, J. Prous, and N. Mealy. 2005. Phytotherapies for Diabetes. Drugs of the Future 30:1253-1282.

Zimmet, P., K.G.M.M. Alberti, and J. Shaw. 2001. Global and Societal Implications of the Diabetes Epidemic. Nature 414:782-787. 


\title{
CHAPTER II
}

\section{HISTORICAL ETHNOBOTANY AND KNOWLEDGE TRANSMISSION OF DIABETES REMEDIES IN A MULTI-ETHNIC SOCIETY}

\begin{abstract}
Diabetes mellitus is an old disease that is affecting new populations. This formerly rare ailment is now common across the globe, with prevalence rates in the world's most populous regions nearing or exceeding 10\%. Many low- and middleincome countries, with the highest future projected rates of prevalence, still rely on traditional medical systems that existed even before the disease was first described. Investigating the history of the ethnobotanical knowledge in these countries provides insight into the fidelity of knowledge transmission processes and the potential risks and benefits of plant selection based on such processes.

Trinidad and Tobago (T\&T) is a multi-ethnic country in the Caribbean with a high incidence of diabetes. My literature reviews found that almost 50 plant species have been used in treating diabetes symptoms in T\&T pre-2000. Though $40 \%$ of these species originated from the Paleotropics, where the ancestors of T\&T's predominantly Afro- and Indo-Trinidadian ethnic groups lived, $56 \%$ of the species were Neotropical natives. Twenty-three percent of the species were common, weedy Neotropical species of disturbed habitats.
\end{abstract}

Using literature reviews of ethnographic publications, the traditional remedies reportedly used to treat diabetes in $\mathrm{T} \& \mathrm{~T}$ were compared to those used in India, western 
Africa, and former European colonies of the Caribbean. Higher levels of similarity were found between antidiabetic remedies used in T\&T and India (20\%) when compared to those remedies common to T\&T and western Africa (8\%).

In the Caribbean Basin, the highest species similarity indices were found for antidiabetic remedies shared between T\&T and three countries: Martinique, Guyana and Jamaica. Social network analyses suggested that across the region, shared colonial heritage and language may have played key roles in ethnobotanical knowledge transmission. As such, Hispanophone nations in Central America, along with other former island colonies of Spain, showed a relatively greater tendency toward withingroup homophily. The numerous citations in publications from Africa, India and across the Caribbean of the two Paleotropical species, Catharanthus roseus and Momordica charantia, suggest the existence of means of diffusion of conserved traditional knowledge, as well as plant material, across the region. Simultaneously, references across the region to species of Aristolochia, Phyllanthus and Senna, suggest innovative use of well- known, pantropical genera.

The combined evidence indicates that Trinidad and Tobago's local antidiabetic pharmacopoeia is primarily of recent innovation and warrants further research to identify the cultural, cognitive, ecological and phytochemical factors that may be involved in novel plant selection processes. It is also evident that Paleotropical species with a long history of use provide safer options for treating DM symptoms. 


\section{INTRODUCTION}

Historical Overview of Diabetes Mellitus

Diabetes mellitus has been a known disease for centuries. A condition that manifested "the passing of too much urine" (Major 1932:186) was described in the Ebers Papyrus of Egypt, written between 1553 and 1550 BC (Bryan 1930). The most comprehensive description of the disease is found in the writings of the $2^{\text {nd }}$ century (A.D.) Greek physician Aretaeus. He used the term "diabetes"- signifying a siphon- to describe the way that copious amounts of water drunk by diabetic patients seemed to pass straight through their bodies and the apparent wasting away that resulted in emaciation in the patients (Major 1932:186). The occurrence of diabetes was infrequent (Major 1932), and one of its symptoms, excessive thirst or "dipsakos," was similar to the more common “hydrops" (dropsy). Nonetheless, Greek physicians, including Galen (129-199 A.D.), were able to distinguish between the two diseases, perhaps because dropsy, unlike diabetes, resulted in water retention (Schadewaldt in von Englehardt 1989:46).

Though the Greeks clearly identified many symptoms of diabetes, the characteristic of sweet-tasting urine is said to have first been described in Indian medical writings dated between 300 B.C. and 600 A.D. These writings referred to an illness characterized by "honey urine" which was termed "madhumeha" (Schadewaldt in von Englehardt 1989:48), and referenced the idea that the sweetness of the urine might attract ants or insects. Thus, the second part of the currently recognized disease name (mellitus), which was coined by Johann Peter Frank in 1794 as “diabetes mellitus seu verus", describes the characteristic sweet taste of the urine of "true" diabetics. He distinguished 
these patients from those having "diabetes insipidus seu spurius", in which the urine is said to be tasteless (Schadewaldt in von Englehardt 1989:53).

Diabetes Mellitus and Botanical Remedies

Despite the advancing knowledge of diabetes, it was not until 1921 that insulin, the current conventional therapy of choice, was discovered by Canadian researchers (Schadewaldt in von Englehardt 1989). Prior to the discovery of insulin, diabetes treatments over the centuries ranged from the plant and mineral-based recipes in Ebers Papyrus (Major 1932) to "purgation, mild diet and steam baths" of Aretaeus (von Engelhardt 1989:3) to dietary therapy prescribed by Karl Petren in the early 1900s (Wilder in von Engelhardt 1989).

One plant remedy, Galega officinalis L. (Fabaceae), commonly called goat's rue or French lilac, was reputedly used for its hypoglycemic action since medieval times in Europe (Bailey and Day 1989). Today, the drug metformin (di-methyl biguanide)--a modified form of the chemical galegine, first identified in G. officinalis - is classified by the World Health Organization as an essential medicine for use in treating Type 2 diabetes (Bailey and Day 2004, WHO 2013).

In the era just preceding the discovery of insulin, one botanical remedy that was used by Europeans was the exotic plant, Syzygium cumini (L.) Skeels (Myrtaceae), a native of the Indian subcontinent (Helmsta“dter 2007). In Japan, just around the time of the discovery of insulin, scientists were testing Panax ginseng C.A. Mey, (Araliaceae) for its ability to reduce blood glucose levels. Panax ginseng is a traditional Chinese 
medicine that was known in ancient Chinese literature for its ability to "quench thirst" (Xie et al. 2005).

In addition to attesting to historic plant use to treat diabetes, the two latter scenarios highlight the movement of knowledge of botanical remedies across culturesan idea supported by other authors who mention the recommendation of Indian "peperi" for gynecological concerns by Hippocrates (Touwaide and Appetiti 2013:367); the influence of Egyptian medicine on the Greek materia medica (Stannard 1982); and the bartering of herbals among Anglo-Saxon and other European clerics in the Middle Ages (Voigts 1979).

Presumably, botanical exchanges occurred from antiquity through to modernity as groups of people migrated between, traded with and conquered other such groups. I suggest further that those knowledge transmission processes were occurring during the 400-year period of mass migrations and cultural reorganizations associated with the European colonization of the Americas.

This chapter addresses the extent to which knowledge transmission influenced the formation of local ethnobotanical pharmacopoeias in a New World setting, given the admixture between several Old and New World cultures that occurred during colonial history. My analysis will specifically focus on those plants used to treat symptoms of Diabetes mellitus.

Currently, the New World countries with the highest rates of Diabetes mellitus (DM) are developing countries, and DM is projected to continue to have its highest rates of prevalence in developing countries by 2040 (IDF 2015). Additionally, the World Health Organization reported that $60 \%$ - $90 \%$ of persons living in developing countries 
still rely on traditional medicines for their primary healthcare needs (WHO 2002). Thus, elucidating the origins of local antidiabetic pharmacopoeias may provide insights into the benefits and risks of traditional medicines to the well-being of their users. Centuries-long use of botanical remedies provides probable evidence for their safety, if not efficacy.

Such use warrants further scrutiny to provide definitive evidence of their safety and efficacy, especially for cultures with limited access to modern systems of healthcare.

The study site selected for this investigation, Trinidad and Tobago (T\&T), is a developing country in the New World with a high prevalence of diabetes (14.5\%) (IDF 2015), where botanical remedies have historically been used to treat many ailments (Williams and Williams 1951). In addition, the country's ethnic and biological diversity provide a basis for significant sources of traditional botanical knowledge.

This chapter addresses the following questions:

(1) What local plant-based antidiabetic remedies were historically known in Trinidad and Tobago?

(2) Is there an ethnobotanical basis for the selection of plants used to treat symptoms of diabetes mellitus in Trinidad and Tobago?

(3) If ethnobotanical evidence exists, is it indicative of conservative or innovative knowledge transmission processes as being instrumental in the formation of the local antidiabetic pharmacopoeia in Trinidad and Tobago?

\section{Background - Country Profile}

Trinidad and Tobago is a twin-island republic with a multiethnic society located in the southern Caribbean, 12 kilometers northeast of Venezuela (Figure 1). Its native 
biodiversity is continental because of its proximity to South America and despite atotal area of $5128 \mathrm{~km}^{2}$, approximately 2,000 native and naturalized plant species have been recorded in T\&T (Kenny 2000). Ethnobotanical and ethnographic studies have identified about three hundred of these plant species that are used medicinally (Clement et al. 2015; Lans 2001; Mahabir 1991; Seaforth et al. 1986; Seaforth et al. 1998; Simpson 1962; Wong 1976). Some naturalized species were likely to have been deliberately introduced by immigrants for medical use (LaGuerre 1987; Mahabir 1991).

The wave of migration that marks the start of the recorded T\&T history occurred in the time of Christopher Columbus in 1498, when he is said to have sighted the threepeaked hilltop on the southeastern end of Trinidad and named the island "La Trinidad" (Anthony 1975). At that time, indigenous peoples inhabited the islands and recent anthropological findings suggest that they had migrated to the islands from the South American mainland (Boomert 2002). European powers (including the Spanish, Dutch, French and British) colonized the islands over the next four centuries (Anthony 1975; Fraser 1891; Ottley 1973).

During that time, there were also forced migrations and enslavement of Africans and the subsequent indentureship of East Indians and Chinese (Anthony 1975). The islands of Trinidad and Tobago (T\&T) were merged as a single entity under British rule in 1889 (Ottley 1973) and were granted independence in 1962 (Anthony 1975). The processes of colonization and migration contributed to T\&T's multiethnic society and, it can be posited, the knowledge that comprises the local botanical pharmacopoeia.

The identity of Trinidad and Tobago's original inhabitants is not definitive. Sources mention the presence of differently named tribal groups such as the Aruacas, 
Chaymas, Tamanacos, and Cumanagotes in Trinidad (Fraser 1891) as well as Arawak, Guayano, Nepoyo Tivitive and Siawani in settlements on the nearby Orinoco delta (Heinen and Garcia-Castro 2000). Recent archaeological and genetic analyses indicate that there were a series of pre-Columbian migrations of indigenous groups from South America throughout the Caribbean archipelago (Hofman et al. 2007; Lalueza-Fox et al. 2001). European explorers recorded both peaceful and hostile interactions with these indigenous peoples in the early to mid- $16^{\text {th }}$ century (Boomert 2002; Heinen and GarciaCastro 2000) and created the general classification of these tribes as "Arawaks" (peaceful) and "Caribs" (hostile), which persisted in the historical record for centuries (Anthony 1975; Boomert 2002). Many groups of indigenous descendants across the Caribbean —in Dominica, Guatemala, Guyana and a remnant in Trinidad—still selfidentify as Caribs (Anthony 1975; Giron et al. 1991; Hodge and Taylor 1957; van Andel, 2000).

Currently, the population of T\&T comprises people of East Indian descent (35.4\%), African descent (34.2\%), and Mixed-African/Indian (7.8\%). Minority groups include Caucasian (0.59\%), Chinese (0.30\%), Syrian/Lebanese (0.08\%), Portuguese (0.06\%), and persons of Mixed Indigenous heritage (a.k.a., Carib) (0.11\%) (GORTT Central Statistical Office 2011). Since most of T\&T's inhabitants have an African or Indian ancestry, this chapter addresses the historical/cultural influence of the migrants from Africa and India on the botanical remedies used by the people of T\&T. The influence of European colonizers and native peoples is also addressed by comparing botanical remedies across former colonies in the Caribbean Basin. 


\section{Background -Plant Selection Theory}

\section{$\underline{\text { Knowledge Transmission }}$}

The selection of plants for a local botanical pharmacopoeia is delimited by the local ecology and cultural and cognitive/linguistic facets of the society (Laguerre 1987; Leonti 2011). These elements can be useful aids in understanding the process of knowledge transmission in a situation where several migrant cultures converge. The ecological conditions delimit plant choices; the cultural aspects dictate the people-groups or individuals who will be the purveyors of the knowledge and, the cognitive aspects underpin how knowledge is recalled, recorded, and shared within and between groups.

Specific consideration of the cultural and cognitive aspects of knowledge transmission highlights three categories: (1) vertical, (2) horizontal,l and (3) oblique. When knowledge transmission occurs from one generation to another (usually as a result of homage to cultural traditions) it is described as vertical knowledge transmission. When knowledge is transmitted between members of the same generation within a cultural group, it is termed horizontal knowledge transmission. Lastly, oblique knowledge transmission occurs across several generations, and is also taken to include knowledge that is transferred across cultures in both written and oral formats (ReyesGarcia et al. 2009; Leonti 2011).

Knowledge transmission can be either conservative or innovative. When knowledge transmission occurs within cultures, especially vertically from parents to offspring, it is expected to be more conservative of traditional practices (Reyes-Garcia et al. 2009). On the other hand, horizontal knowledge transmission across cultures where language barriers exist, such as among slaves of different tribes or between slaves and 
indigenous people, would favor a syncretic type of innovation (Laguerre 1987). Finally, it is to be expected that in comparison to oral systems of transmission, knowledge that is transmitted in a written form will aid in conserving medicinal knowledge traditions within a culture (Leonti 2011).

To examine the historical record of known antidiabetic plants for evidence in support of knowledge transmission, one would look for the parallel use of medicinals of the same species by geographically dislocated but historically-related cultures (McClure 1982). Relatedly, knowledge transmission may also be evidenced by shared names (or cognates) and uses such as wais (Shuar) and guayusa (Quichua) for Ilex guayusa (Aquifoliaceae) (Bennett et al. 2002). Other supporting evidence might be the parallel use of non-native plants across people groups that share a common adopted language. However, where the greater proportion of a local pharmacopoeia is comprised of nonnative species, especially food plants, this may suggest innovation (Bennett and Prance 2000).

\section{Migration}

When groups of people migrate to a new environment, two key opposing processes are at work: acculturation and resilience. Through acculturation, migrants adapt their cultural identity by replacing or modifying elements of their cultural norms. With resilience, migrants retain their cultural identity by maintaining elements of their cultural norms (Pieroni and Vandebroek 2007).

Some key factors that determine the extent to which acculturation or resilience processes occur in the selection of local botanical pharmacopoeia by a migrant group of people may include the following (as outlined in de Medeiros et al. 2012): 
(1) the degree of floristic and environmental similarity between home and host country

(2) variation in the prevalence of health conditions between home and host country

(3) the degree of contact with local populations in the host country,

(4) the involvement of social networks and the degree of contact between migrants and their homeland and

(5) the ability to and ease of acquiring plants via importation

The greater the similarity between migrants' original and adopted environments, the greater the likelihood that migrants will find similar plants and retain traditional knowledge of familiar disease treatments (resilience). Greater contact and interaction between migrants and the native people will increase botanical knowledge exchange (acculturation). Conversely, the greater the contact or accessibility that migrants have to their place of origin, the higher the likelihood of migrants retaining their cultural practices using familiar remedies (resilience).

\section{METHODS}

To generate a list of the traditional botanical remedies of Trinidad and Tobago (T\&T) used to treat symptoms of diabetes, I searched T\&T's ethnobotanical or ethnographic publications and compiled a database of medicinal plants. Accepted scientific names, family classifications and places of origin or natural range of the species were derived from Tropicos (2016), GRIN (2016), Stevens’ Angiosperm Phylogeny 
Group (2001) and The Plant List (2013). For current scientific names, preference was given to the information cited in The Plant List. Since vouchered specimens were not always cited, scientific names reflect the most likely species given the information provided.

Subsequently, I consulted accounts of the history of T\&T to identify the countries or regions in Africa and India from which slaves and indentured laborers were conscripted. Texts (Eltis and Richardson 2010; Roopnarine 2007; Weller 1968) and an online database (Voyages Database 2016) that referenced primary historical documents, such as ship registries and other related documents were then selected for use.

Additionally, I chose a third region for comparison of plant use-referred to herein as the Caribbean Basin. It includes the Bahamas, the Yucatan Peninsula, the islands of the Greater and Lesser Antilles, Central America, and northern South America (Santiago-Valentin and Olmstead 2004). These are regions bordering the Caribbean Sea that have had any combination of the following historical features that are similar to those of T\&T: European colonization, enslaved African labor migration, indentured East Indian labor migration, or remnant populations of indigenous tribes.

Finally, I searched through ethnobotanical publications to find species used as antidiabetics for all of the geographical areas of interest. I used Google Scholar, as well as the databases Web of Science, and PubMed, with search terms "ethnobotanical study/survey/inventory" (or "medicinal plants"/ "medicinal flora"/ "traditional medicine"/ "folk medicine") + "Africa/India/Latin America/Caribbean" + "diabetes/ antidiabetic/ hypoglycemic". I also searched for similar Spanish and French terms. 
Articles and books found in these searches were scoured for information on plants used to treat diabetes. I also used the reference lists of these sources to find additional source material on that area's ethnobotanical remedies. To reduce the likely impact of external influences (such as the internet) on the local traditional knowledge recorded in these sources, I delimited the date range to those studies that were completed before 1999, except in cases where the group being studied was said to be tribal or indigenous (and, therefore, assumed to be fairly isolated from technology). The resulting lists of shared medicinal plants were compiled by region, namely Africa, India and Caribbean.

Data Analysis

To estimate the degree of similarity between Trinidad and Tobago's ethnobotanical remedies and those of the selected regions, I used two species similarity measures: the percentage similarity $\left(\mathrm{P}_{\mathrm{s}}\right)$ and Jaccard's index of similarity $(\mathrm{JI})$ (Junsongduang et al. 2014). For a given locale, percentage similarity was calculated as: $\mathrm{P}_{\mathrm{s}}=(\mathrm{c} / \mathrm{B}) * 100$, where $\mathrm{c}=$ number of antidiabetic species common to both that locale and Trinidad and Tobago, and $\mathrm{B}=$ number of antidiabetic species recorded for Trinidad and Tobago. Jaccard's index of similarity for a given locale was calculated as: $\mathrm{JI}=[\mathrm{c} /$ $(\mathrm{a}+\mathrm{b}+\mathrm{c})]^{*} 100$ where $\mathrm{a}=$ number of unique antidiabetic plant species of that locale, $\mathrm{b}=$ number of unique antidiabetic plant species of Trinidad and Tobago, and $\mathrm{c}=$ the number of common antidiabetic plant species between both locations. The percentage similarity emphasizes shared species, while the Jaccard index tends to highlight unique species.

A Social Network Analysis (SNA) was completed using the data on the antidiabetic genera of the Caribbean Basin as a proxy for the flow of shared knowledge 
across the region (Borgatti 2005). The data set was narrowed to include only those antidiabetic genera that were shared by two or more countries. The list was converted into a bimodal, binary matrix using MS Excel to indicate the presence (1) or absence (0) of each genus among the antidiabetic genera for each country/region. The matrix was then entered into the SNA software UCINET® and then converted to visual graphs using the corresponding visual software package NetDraw® (Borgatti, et al. 2002). In the visual graphs, the proximity of country nodes to each other is based on their geodesic distance which is defined as the length of the shortest path between two nodes (Borgatti and Everett 1997) and is a function of the number of shared ties (genera).

As part of the SNA, further analyses involved measuring homophily for the different countries or regions grouped according to the attributes of location and language. Homophily describes the tendency for nodes with a shared attribute (e.g., language) to have more ties to each other than to nodes with non-shared attributes. One way that UCINET ${ }^{\circledR}$ determines homophily of a network is by using the E-I index, which is calculated as

$$
\text { E-I Index }=(e-i) /(e+i)
$$

where $e$ represents the number of external ties and $i$ represents the number of internal ties for each identified subgroup. Thus the value of the E-I Index can range from -1 , which is indicative of complete homophily, where nodes within each subgroup are only tied to each other, to +1 , which is indicative of complete heterophily where nodes are only tied to nodes outside of the subgroup (Everett and Borgatti 2012).

The purpose of the SNA was to determine whether the antidiabetic genera were more similar among countries in close proximity or among those with shared language so 
as to identify the most probable means by which knowledge transmission may have occurred across the region.

\section{RESULTS}

Trinidad and Tobago's Antidiabetic Plants

The ethnographic studies that I sought information on the historically-used antidiabetic plant species of Trinidad and Tobago were conducted between 1959 and 1999 and published as either journal articles or books (Lans 2006; Mahabir 1991; Mahabir and Gulliford 1997; Seaforth et al. 1986; Seaforth et al. 1998; Simpson 1962; Wong 1976). Only one of these studies (viz., Mahabir and Gulliford 1997) specifically set out to chronicle plants used for diabetes; the other studies either recorded plant use among a specific ethnic group (Mahabir 1991), within a specific community (Simpson 1962; Wong 1976), or broadly across the country (Seaforth, et al. 1986; Seaforth, et al. 1998; and Lans 2006). Altogether, these sources chronicle the knowledge of 48 putative antidiabetic plant species that belong to 45 genera within 38 families (Table 1). Fabaceae and Asteraceae are represented by four species each, while Aristolochiaceae, Cucurbitaceae, Moraceae, and Phyllanthaceae are represented by two species each.

Among the 48 species, only one plant (Laportea aestuans (L.) Chew) is recorded as having a native pantropical range. Twenty-seven species (56\%) are Neotropical natives, with a subgroup of 18 native to Trinidad and Tobago or the Caribbean region. Another sixteen (33\%) of the antidiabetic species are Paleotropic natives-three originated in or near the African continent, eight originated in or near the Indian 
subcontinent, and four species have a native range that includes both Africa and India; the remaining Paleotropic native, Artocarpus altilis (Parkinson ex F.A. Zorn) Fosberg (Moraceae), is a widely cultivated staple that is native to Melanesia and Polynesia. As for the final four of the 48 putative antidiabetic remedies, their place of origin is extratropical. Aloe vera (L.) Burm. f.( Xanthorrhoeaceae) originated in North Africa and the Canary Islands, Cannabis sativa L. (Cannabaceae) originated in Central Asia, while the two edible fruits, Morus alba L. (Moraceae) and Citrus x aurantium L. (Rutaceae), originated in temperate China. All four species are now widely cultivated across the tropics (GRIN 2016).

The habit or life forms of the 48 species include trees (14), shrubs (9), herbs (16), and vines (9). As for the plant parts used, leaves (21) were the most common, then roots (5), fruits (3), and seeds (3). In other cases, the entire plant was used or no plant part was specified.

The habitats and uses of Trinidad and Tobago's recorded antidiabetic plant species (Table 1) are various. Several (33\%) are common, volunteer or pioneer species of disturbed habitats, including 11 of Neotropical origin, e.g., Ageratum conyzoides L., Bidens pilosa L., Cordia curassavica (Jacq.) Roem. \& Schult., Phyllanthus amarus Schumach. \& Thonn., Ruellia tuberosa L. and Spermacoce verticillata L. Several species are cultivars used either as food (e.g., Artocarpus altilis, Cajanus cajan (L.) Millsp. and Persea americana Mill.), or as seasonings (e.g., Bixa orellana L., Eryngium foetidum L. and Cymbopogon citratus (DC.) Stapf), or as popular medicines (e.g., Aloe vera (L.) Burm. f.and Senna italica Mill.). Yet other specially cultivated species are used as ornamentals (e.g., Antigonon leptopus Hook. \& Arn., Catharanthus roseus (L.) G. Don 
and Gomphrena globosa L.), and in religious rituals or ceremonies (e.g., Azadirachta indica A. Juss., Cannabis sativa, and Cola nitida (Vent.) Schott \& Endl.). Only two species (Aristolochia rugosa L. and Spiranthes acaulis (Sm.) Cogn) are rare, less accessible species of intact forest or savanna ecosystems.

Though most plants in the local pharmacopoeia have English common names, the local names of some plants include creolized French (e.g., zebapique and pataçon), Hindi (e.g., ganja and kharmi bhaji) and Spanish (e.g., coralita and granadilla).

\section{Places of Origin}

Slaves in T\&T came from many parts of Africa (Eltis and Richardson 2010, Table 2). As the names for these countries and regions have changed over time, I compared the maps provided in the online database (Voyages Database 2016) to historical maps of the African continent (Barraclough 1978 \& 1988) to identify the corresponding country names. These place names were then inserted into a map of West Africa (Figure 2) and were also used to facilitate searches for ethnobotanical surveys. The map (Figure 2) displays only West African countries with a coastline (and hence a port) on the Atlantic Ocean. Slaves might have originated from diverse areas within West Africa; however, shipping registries generally only recorded the ports from which slaves embarked (Eltis and Richardson 2010).

Indentured Indian laborers in Trinidad also came from multiple areas of the subcontinent; there are no historical records that indicate their arrival in Tobago (Weller 1968 and Roopnarine 2007). Places cited in Table 3 reflect historical names and provinces as listed in Muthiah (1987), as these most closely match the names and 
provinces referred to in the historical sources I used for information on Indian ethnobotany.

Shared Antidiabetic Species

\section{$\underline{\text { Africa and India }}$}

The lists of local antidiabetic remedies that Trinidad and Tobago share with Africa (Table 4) and India (Table 5) indicate shared species and genera. When available, the plant part used and the region where such use was recorded were also indicated.

Eleven genera and ten families of antidiabetic western African species were shared with T\&T (Table 4). Cucurbitaceae is the only family represented by more than one genus. Four species_Carica papaya, Catharanthus roseus, Ipomoea aquatica, and Scoparia dulcis — were shared and of these four, two are of Neotropical origin. Information on the plant parts used and the specific countries or regions of use was lacking in most cases. For the comparison of T\&T's and western Africa's antidiabetic species, the percentage similarity was $8.3 \%$ but the Jaccard similarity index (which includes non-shared species in its calculation) was lower at $4.9 \%$ as there were 33 nonshared antidiabetic species.

Eighteen genera and ten plant species were shared by India and T\&T (Table 5). All told, these plants represent 16 families, of which Cucurbitaceae and Fabaceae are represented by two species each. Two genera, Coccinia in Curcurbitaceae and Senna in Fabaceae, were cited by several sources. Azadirachta indica showed the broadest application, with uses indicated in eight sources from five provinces/regions and all of its parts being used. Notably, of the ten shared species, four (Carica papaya, Cissampelos 
pareira, Phyllanthus amarus, and Scoparia dulcis) are Neotropical natives. For T\&T and India, the percentage similarity of species was $20.8 \%$. However, the Jaccard similarity index was much lower (6.4\%), likely because there were 108 non-shared antidiabetic species recorded for India. When looked at sub-regionally, two states had significant numbers of unique antidiabetics, West Bengal (54) and Tamil Nadu (30), with 4 and 6 species (respectively) shared with T\&T.

\section{$\underline{\text { Caribbean Basin }}$}

Twenty-three countries and one region (Yucatan peninsula) in the Caribbean Basin have recorded antidiabetic plant remedies representing 151 different genera. Apart from Trinidad and Tobago, five locations-Martinique (25), Venezuela (24), Yucatan Peninsula (24), Dominican Republic (23) and Jamaica (21) — had twenty or more antidiabetic genera.

The antidiabetics of Trinidad and Tobago that were shared with other Caribbean Basin locations represented 30 species/genera within 26 families (Table 6). Asteraceae was represented by three genera, while Fabaceae and Moraceae were represented by two genera each. Popular medicinals of Aloe and Senna, along with common weedy species, Bidens and Phyllanthus, were all cited in five or more locales. Certain fruit/food plants, Artocarpus altilis, Cocos nucifera, Persea americana, and Citrus species, were also cited by at least three sources. Catharanthus roseus and Momordica charantia seemed to enjoy broad usage across the Caribbean region with use indications from nine and sixteen locations, respectively. Across all species/genera, the plant parts most typically used were the leaves; flowers and seeds were least typical. 
The three countries in the Caribbean Basin that had the highest number of antidiabetic species in common with T\&T were Martinique, Guyana, and Jamaica (Table 7). The values for percentage similarity $(25.0 \%, 22.9 \%$, and $20.8 \%$ respectively) were similar to their Jaccard indices of similarity $(19.4 \%, 18.6 \%$ and $16.9 \%$ respectively), indicating that these three countries had similar ratios of shared and unique species.

Besides Curacao and Guadeloupe, which had no shared antidiabetic remedies with T\&T, the least similar countries based on similarity indices (Table 7) were the Bahamas, Cuba, the Commonwealth of Dominica, and Turks and Caicos, which all had similarity values of $2 \%$ or less.

The social network analysis graphs (Figures 4, 5 and 6) display the nodes of primary interest (countries) in proximity to each other, using the geodesic distances between nodes, as well as color coded attributes. The resulting images show one, somewhat distinct, large group of countries connected by the most commonly cited genera in the middle, with five countries on the periphery: Guadeloupe and Curacao on the left, Cuba on the lowest right and Turks and Caicos and Dominica on the upper right.

Within the large group the sub-group on the upper left that was comprised mainly of Central American Spanish-speaking countries, showed no distinct attribute alignments. There were some apparent sub-groupings on the lower right of the graphs. The three apparent subgroups comprised Honduras, Haiti, and the Dominican Republic; Jamaica, Martinique, and Puerto Rico, and Trinidad and Tobago, Guyana, and Suriname.

The low attribute alignment evident on the graphs is reflected in the values of the E-I indices for the entire group. On a scale where $-1=$ greatest homophily (greater proportion of internal group ties) and $+1=$ lowest homophily (greater proportion of 
external group ties), the E-I index for language was 0.253 and for location was 0.566 . Nevertheless, within the Spanish language subgroup, the E-I index was notably lower (0.037), suggesting greater homophily than the English (0.257), French (0.805) or Dutch (1.00). As for E-I indices for location, only one subgroup (Central American) displayed a lower value (0.402) than the overall E-I index value for location. The remaining subgroups had E-I indices of 0.529 (Greater Antilles), 0.577 (South American), 0.782 (Lesser Antilles), and 1.000 (North Caribbean), reflecting an increasing heterophily as seen in the graphs.

\section{DISCUSSION}

Trinidad and Tobago's Antidiabetic Plants

The group of botanical remedies of Trinidad and Tobago (T\&T) recorded for use in the treatment of diabetes symptoms displays features described in other studies and pharmacopoeias, such as greater representation from the speciose Asteraceae and Fabaceae (van Andel 2000, Clement et al. 2015), higher usage of leaves than any other plant part, and the inclusion of several weedy species of disturbed habitats (Wong 1976, Voeks 2004). Notably, though, there were no Mediterranean or European species among the selected remedies, even though some such species (e.g., Artemisia absinthium L. and Taraxacum campylodes G.E. Haglund [syn. Taraxacum officinale F.H. Wigg]) were included among the antidiabetics of other Caribbean Basin countries. 
Knowledge Transmission

As regards vertical knowledge transmission, Indo-Trinidadians have maintained many aspects of their family structures throughout the indentureship process (Weller 1968). Furthermore, in the context of oblique knowledge transmission, IndoTrinidadians retained their use of written medical traditions based on Ayurveda and Unani systems of medicine (Mahabir 1991). Both of these elements would tend toward greater conservatism in Indo-Trinidadians' ethnobotanical applications.

Thus, the finding that the local antidiabetic pharmacopoeia in Trinidad and Tobago has greater similarity to that of India than to Africa, as indicated by both the percentage similarity (Indian - 20\% versus African 8\%) and Jaccard similarity indices (6.4\% versus $4.9 \%)$, falls in line with the expected differences in conservatism. In general, there are fewer historical records of the botanical remedies of western Africa (Lantum 1980) than of India. Hence, the lower conservatism observed for the African species may actually be an artifact of incomplete record-keeping, limited access to original source material, or a paucity of research.

Another element in support of ethnobotanical conservatism relates to the common names used for the local remedies. Among these names, only obie seed = "obi" (Cola nitida) reflects a name of African heritage, specifically southern Nigeria, (Ayensu 1978), although there is no historical record of its use as an antidiabetic in western Africa. On the other hand, the following five plants have common names originating in or modified from those used in India: neem = nim (Azadirachta indica); ganja = ganja $($ Cannabis sativa $)$, kharmi bhaji = kalmishak $($ Ipomoea aquatica $)$; caraaili = karela $($ Momordica charantia $)$; and saijan = sainjna $($ Moringa oleifera $)($ Jain and de Filipps1991). As such, 
the argument for vertical knowledge transmission resulting in greater conservatism between Trinidad and Tobago's and India's plants is supported.

A potential case of innovation among Indo-Trinidadian remedies is noted here. The Neotropical Eryngium foetidum, which is known among Indo-Trinidadians as bandhaniya, is likely named from a composite of the expression ban (meaning wild or common) and the name dhaniya, the Hindi name for cilantro (Coriandrum sativum L.), an Indian seasoning that has a similar flavor profile to bandhaniya (Jain and de Filipps 1991). How Indo-Trinidadians came to know this Neotropical plant and use it as a substitute for cilantro may possibly be the result of oblique knowledge transmission from indigenous peoples via other people groups (perhaps Europeans). A possible parallel case is the naming of the same plant in Puerto Rico and among the Caribs of Guatemala, where no East Indian indentured laborers were recruited. In Puerto Rico, Eryngium foetidum is called el culantro del monte (Benedetti 2000), while in Guatemala it is called culantro de culebra (Giron et al. 1991), an adaptation of the common Spanish name, cilantro. Admittedly though, there is the possibility of independent discovery, as this plant is a common, volunteer species with a markedly distinct aroma.

The results of the social network analyses (Figure 4) suggest that both language and locality have played a role in the transmission of knowledge of botanical remedies in the Caribbean. The grouping of the countries of Latin-speaking Central America on one side of the graph indicates the role of shared language. Yet their separation from the Latin-speaking islands of the Greater Antilles indicates the possibility that locality is also a contributory factor. As for T\&T, its positioning on Figure 4 in relation to Jamaica and Guyana (as compared to Cuba and Venezuela), as well as its high similarity indices with 
these two countries supports the idea that their common language (English) was the greater factor in knowledge transmission than locality. Nevertheless, other historical factors such as migration events between countries with shared colonial heritage may also be considered.

Migration

The impact of migration on the plant selection process, as indicated in the introduction, was linked to five factors, which included the similarity between the floristic and environmental features, as well as health conditions, of the former and current location; the degree of contact of migrants with people in the new location; and the extent to which contact with people and access to plants is maintained between the old and new locations

For the two major migrant groups of East Indians and Africans who came to T\&T, the similar nature of the tropical climates of their homeland and their new environment may have meant a greater likelihood of encountering similar infectious agents, parasites and pests and their associated health conditions. At the same time, a shared tropical environment meant that many familiar genera and even species were available to treat these health concerns and potentially that migrants may have been able to cultivate those familiar food/medicinal plants.

As previously indicated, only $35 \%$ of T\&T's recorded antidiabetic remedies are of Paleotropic origin; nevertheless, it must be recognized that some of the Neotropical species belong to genera that are widely distributed in the Paleotropics, (e.g., Senna and Aristolochia). As such, their generic similarity may have allowed migrants to apply 
previously known uses to the Neotropical species of the same genus. Among descendants of West African slaves in Suriname and in Brazil, there are many congenerics that were given the same name as their African counterparts and, in some instances, those plants were also used in similar fashions (Voeks 1990; van Andel et al. 2014). Such occurrences reveal simultaneous elements of conservatism and innovation.

In Trinidad and Tobago, contact between the indigenous tribes and the migrant groups is more likely to have occurred for the African slaves, as they are first recorded in Trinidad in 1610. In contrast, by the time the East Indians were brought to Trinidad, beginning in 1845 , there were very few indigenous people remaining - their population being estimated at around 1,100 in a population of over 18,000 at the start of British rule in 1797 (Anthony 1975).

Evidence of indigenous (i.e. Carib) influences includes common names and similar plant use. In the case of Bixa orellana, the local name, ruku or roucou is likely a cognate of the indigenous name "surúkuli" that was used by indigenous Caribs in the Commonwealth of Dominica to describe the preparation of the seeds of B. orellana in oil for application to the body (Hodge and Taylor, 1957:587). In Brazil, a similar name, "urucum", is said to be the name used by indigenous Amazon people for B.orellana, which was also similarly applied to the body (Ferreira et al. 2012). In the Caribbean, the common name, "roucou", is also recorded in Haiti (Brutus and Pierre-Noel, 1960). For Persea americana, the common name " $z$ 'baca" that is recorded among the Caribs in Montserrat is similar to the common name, zaboca used in T\&T (Brussell 1997). The Caribs' use of the Neotropical species Spondias mombin (hog plum) and Stachytarpheta 
jamaicensis (vervine) as a tea for women after giving birth, is similarly recorded among persons of African descent in T\&T (Berry 2005; Lans 2001),

The extent to which migrants maintained contact with or access to their homeland and its plants was greater for Indian indentured laborers than African slaves. Many indentured laborers were repatriated to India after a period of either 5 or 10 years of service. In some instances, they subsequently re-emigrated to Trinidad (Weller 1968). There is no record of a system of repatriation for slaves to Africa. Relatedly, there were stricter requirements for the recruitment, shipment and tenure of Indian indentured laborers than existed for the African slaves, including the provision of culturally familiar food rations, with plant-based seasonings (e.g., turmeric [Curcuma longa L.] and coriander seeds [Coriandrum sativum L.]) (Weller 1968). This degree of contact with the familiar may have allowed for the strengthening of cultural identity (resilience) among the Indian immigrants. Nevertheless, Laguerre (1987) does suggest that peanuts (Arachis hypogaea L.) and pigeon peas (a.k.a. Congo peas, Cajanus cajan) were used to feed slaves on the voyage from the African continent; but it is not certain how many other culturally familiar foods were provided to them.

Evidence of the impact of the degree of contact on the botanical selections of Indo- vs Afro-Trinidadians is substantiated by the many introduced food plant species that form part of the antidiabetic remedies used by both Indians and Indo-Trinidadians (e.g., Moringa oleifera) (Mahabir 1991). Conversely, though Cajanus cajan is still an important cultural food for Afro-Trinidadians, its use as an antidiabetic is not shared with Africa. 
More evidence that may be looked at is the similarity of the plant parts used. For the African-T\&T comparison (Table 4), Catharanthus roseus leaves and Momordica spp. fruit are used in both locations. For the Indian-T\&T comparison, Azadirachta indica leaves, the whole plant of Catharanthus roseus, Cocos nucifera flowers, and Momordica charantia fruit are used in both locations.

Thirdly, in terms of the proportion of T\&T's shared antidiabetics of Paleotropic origin, there were two species and three genera shared with Africa, namely, Catharanthus roseus, Ipomoea aquatica, Coccinia spp., Momordica spp., and Senna spp. (Table 4). The Paleotropic plants shared between Trinidad and Tobago and India (Table 5) include the five species/genera mentioned above and five additional species/genera: Abrus precatorius, Aloe spp., Azadirachta indica, Cocos nucifera, and Moringa oleifera. This difference in the number of shared species/genera suggests the possibly that a greater level of contact produced greater commonality between India and Trinidad and Tobago's pharmacopoeia.

Looking at the Caribbean Basin again, the combined elements of multiple migration/colonization events can be expected to produce varied cultural milieus within these countries, which could in turn affect plant selection. One example of such migration occurred when French plantation owners and their slaves left from Haiti, Martinique and other French-run colonies for Trinidad, in response to that Spanish colony's 1783 cedula which sought to lure Roman Catholic settlers by offers of low taxes and land for settlement according to the number of slaves that plantation owners possessed (Fraser 1891). Its occurrence may be responsible for the significant similarities between T\&T and Martinique' plant remedies (Table 7 and Figure 4), though 
Trinidad was never ruled by the French. The common names of many of the local plants (e.g., Zebapique $=z^{\prime}$ herbe à pic for Neurolaena lobata ) in Trinidad reflect this French influence. This inter-island, intra-regional migration event is probably not the only such event and highlights the significant opportunities for oblique knowledge transmission to have occurred within the Caribbean Basin.

Another possible example of the influence of different colonization/migration events is seen in the different composition of the populations of two islands of the Netherlands Antilles, Aruba and Curacao. Though located less than 50 miles apart, and having a shared Dutch colonial heritage, in Curacao the population was comprised predominantly of African descendants, while in Aruba the populace was mainly of Amerindian descent. The Aruban local pharmacopoeia was found to include fewer plants and plant uses (Morton 1968).

Oblique knowledge transmission within the Caribbean Basin may potentially be responsible for the common pattern of using Neotropical native species from the pantropical Aristolochia, Phyllanthus and Senna genera to treat diabetes symptoms-all three are known for having distinctly identifiable reproductive features, such as the flowers of Aristolochia that are shaped like a smoker's pipe. Conversely, perhaps those groups that had used congeneric Paleotropic species in their place of origin adopted the new-found species of Aristolochia, and maintained knowledge of their use through vertical transmission. However, for diabetes remedies, the former scenario of oblique transmission between groups facilitated by interregional movement seems more likely.

The two most regularly cited antidiabetic remedies of T\&T actually originated in the Paleotropics. Momordica charantia and Catharanthus roseus are used as antidiabetics 
in Africa and India, and throughout the Caribbean, including countries that did not have Indian indentured laborers. As oblique knowledge transmission through oral means is not typically conservative in its outcome, this fact is a cause for curiosity and warrants further investigation - perhaps this pattern of usage may reflect the influence of written oblique transmission, the source of which it would be important to identify.

For Momordica charantia, some linguistic cues suggest Indian influence in the Lesser Antilles where the weedy species has become naturalized and is locally called pomme coolie or koukouli (Berry 2005; Quinlan 2004). The first name might be coarsely translated as a French-based vernacular for "Indian apple," as Indians were often derogatively referred to as "Coolies." However, this name is suggestive of the use of the plant as food more so than medicine, which may be the original basis for its spread across the Caribbean.

\section{Conclusion}

European colonization of the Americas strongly influenced Caribbean pharmacopoeias. This 400-year period of exploration and colonization was the precipitant for some of the largest human migration events in the world. The resulting cultural milieus of the New World are testament to the fundamental processes of acculturation and resilience that shape any migrant-based society, and, as was the focus of this chapter, influence local botanical pharmacopoeias.

In Trinidad and Tobago, the local antidiabetic pharmacopoeia comprised of 48 plant species evidences more innovation than conservatism, with a higher proportion of New World species that are similar to those used in several countries across the 
Caribbean Basin. Shared language appears to be more important than close proximity in the transmission of botanical knowledge of plant remedies among countries in the Caribbean region. Inter-regional migration is more likely to occur between locations with a common language and historical (colonial) trading relationships.

A notable exception to the use of New World species is among the plants primarily used by Indo-Trinidadians, where a greater amount of conservatism is evident. This can be attributed in part to the preservation of familial and cultural knowledge systems during and following the migration process, in addition to the comparatively recent (mid-nineteenth century) arrival of East Indians to the region.

The combined evidence indicates that Trinidad and Tobago's local antidiabetic pharmacopoeia is primarily of recent innovation and warrants further research to identify the cultural, cognitive, ecological and phytochemical factors that may be involved in novel plant-selection processes. 
Figure 1 - Map of the Caribbean Basin showing Trinidad and Tobago (in red box)

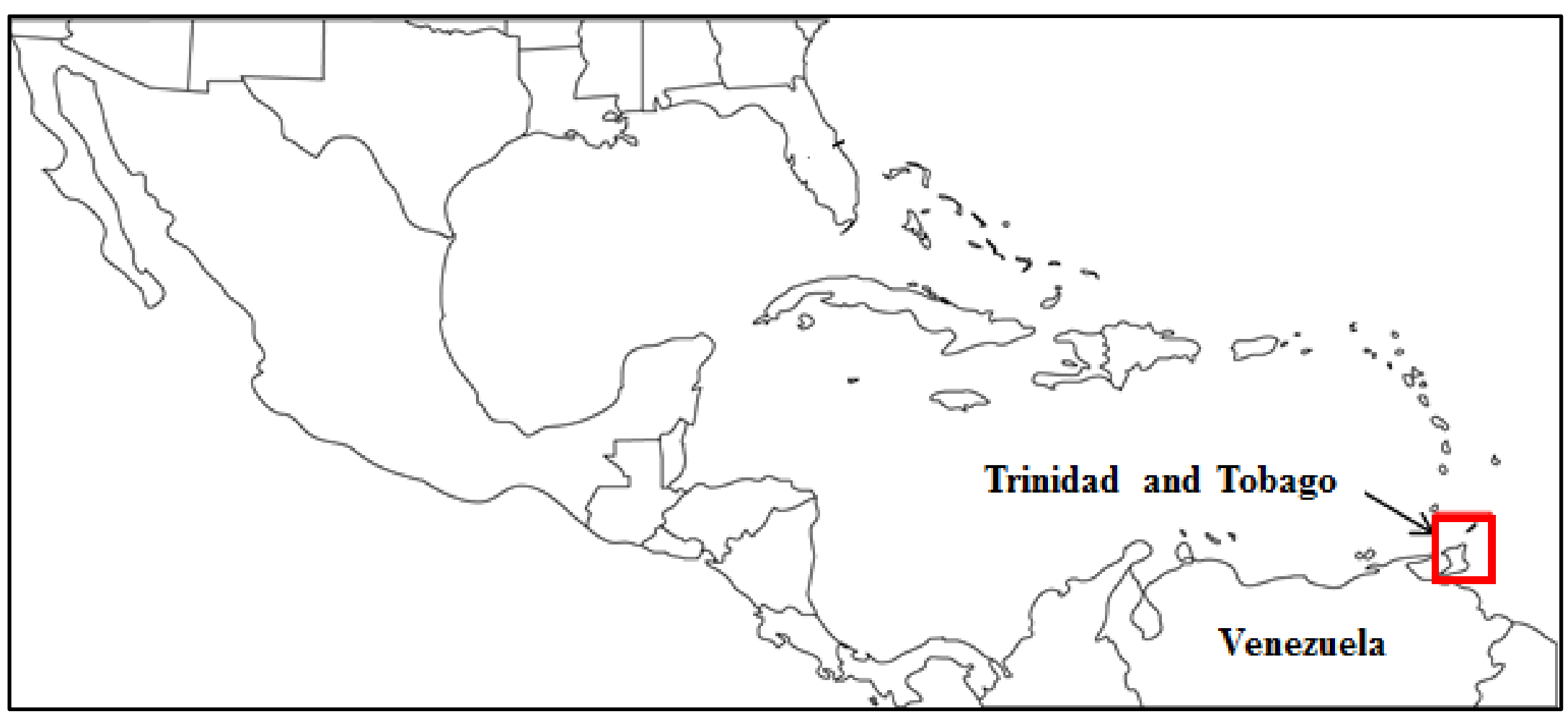


Table 1 - Plants historically used as antidiabetics in Trinidad and Tobago

\begin{tabular}{|c|c|c|c|c|}
\hline Scientific Name & Family $^{1}$ & Local Name(s) & Plant Part & Distribution / Native Range $^{2}$ \\
\hline Abrus precatorius L. & Fabaceae & $\begin{array}{l}\text { crab eye/ licorice/ } \\
\text { jumbie bead }\end{array}$ & aerial parts & $\begin{array}{l}\text { Native to Africa, temperate and } \\
\text { tropical Asia, Australia \& the Pacific; } \\
\text { naturalized in the neotropics. }\end{array}$ \\
\hline Ageratum conyzoides (L.) L. & Asteraceae & zeb-a-fam & root & $\begin{array}{l}\text { Native to South America and the } \\
\text { Caribbean; naturalized and/or } \\
\text { cultivated globally }\end{array}$ \\
\hline Aloe vera (L.) Burm. f. & Xanthorrhoeaceae & aloes & not specified & $\begin{array}{l}\text { Native to Canary Islands and North } \\
\text { Africa; widely cultivated and } \\
\text { naturalized }\end{array}$ \\
\hline Annona muricata $\mathrm{L}$. & Annonaceae & soursop & not specified & $\begin{array}{l}\text { Neotropical origin - West Indies; } \\
\text { naturalized across the tropics; widely } \\
\text { cultivated }\end{array}$ \\
\hline $\begin{array}{l}\text { Antigonon leptopus Hook. \& } \\
\quad \text { Arn. }\end{array}$ & Polygonaceae & coralita & vine & $\begin{array}{l}\text { Native to Mexico \& Central America; } \\
\text { naturalized and cultivated elsewhere }\end{array}$ \\
\hline Aristolochia rugosa Lam. & Aristolochiaceae & matroot & whole plant & $\begin{array}{l}\text { Native to South America and the } \\
\text { Caribbean }\end{array}$ \\
\hline Aristolochia trilobata $\mathrm{L}$. & Aristolochiaceae & twef or tref & leaves & $\begin{array}{l}\text { Native to South America and the } \\
\text { Caribbean; often cultivated }\end{array}$ \\
\hline $\begin{array}{l}\text { Artocarpus altilis (Parkinson } \\
\quad \text { ex F.A.Zorn) Fosberg }\end{array}$ & Moraceae & breadfruit & $\begin{array}{l}\text { yellowing } \\
\text { leaves }\end{array}$ & $\begin{array}{l}\text { Native to tropical Asia--Melanesia } \\
\text { and Polynesia; naturalized in the } \\
\text { Pacific; cultivated throughout the } \\
\text { tropics }\end{array}$ \\
\hline Azadirachta indica A. Juss & Meliaceae & neem/nim or neeb & leaves & $\begin{array}{l}\text { Native to tropical Asia; naturalized } \\
\text { and cultivated elsewhere }\end{array}$ \\
\hline
\end{tabular}


Table 1 - (continued)

\begin{tabular}{|c|c|c|c|c|}
\hline Scientific Name & Family ${ }^{1}$ & Local Name(s) & Plant Part & Distribution / Native Range $^{2}$ \\
\hline Bidens pilosa $\mathrm{L}$. & Asteraceae & $\begin{array}{l}\text { needle grass/ } \\
\text { railway daisy }\end{array}$ & leaves & $\begin{array}{l}\text { Exact native range obscure-includes } \\
\text { North, Central and South America as } \\
\text { well as the Caribbean; naturalized } \\
\text { widely }\end{array}$ \\
\hline Bixa orellana $\mathrm{L}$. & Bixaceae & roucou/ruku & leaves, root & $\begin{array}{l}\text { Native to American tropics; excl. } \\
\text { Caribbean; cultivated and naturalized } \\
\text { elsewhere in tropics }\end{array}$ \\
\hline Bontia daphnoides L. & Scrophulariaceae & olive bush & leaves & $\begin{array}{l}\text { Native to the Caribbean and } \\
\text { Venezuela }\end{array}$ \\
\hline Cajanus cajan (L.) Millsp. & Fabaceae & pigeon peas & $\begin{array}{l}\text { leaves and } \\
\text { stems }\end{array}$ & $\begin{array}{l}\text { Widely cultivated in the tropics; } \\
\text { originated in India }\end{array}$ \\
\hline Cannabis sativa $\mathrm{L}$. & Cannabaceae & ganja/marijuana & $\begin{array}{l}\text { leaves, shoots } \\
\text { and seeds }\end{array}$ & $\begin{array}{l}\text { Probable origin - Central Asia; now } \\
\text { widely naturalized and cultivated } \\
\text { globally }\end{array}$ \\
\hline Carica papaya L. & Caricaceae & paw-paw & green fruit & $\begin{array}{l}\text { Native to S. Mexico and Central } \\
\text { America; naturalized in the Caribbean } \\
\text { \& African tropics; cultivated } \\
\text { elsewhere }\end{array}$ \\
\hline $\begin{array}{l}\text { Catharanthus roseus (L.) G. } \\
\text { Don }\end{array}$ & Apocynaceae & periwinkle & $\begin{array}{l}\text { whole herb } \\
\text { (flowers, } \\
\text { leaves, root) }\end{array}$ & $\begin{array}{l}\text { Native to Madagascar; naturalized } \\
\text { and cultivated in tropics and } \\
\text { subtropics }\end{array}$ \\
\hline $\begin{array}{l}\text { Chromolaena odorata (L.) } \\
\text { R.M. King \& H. Rob. }\end{array}$ & Asteraceae & Christmas bush & flowers & $\begin{array}{l}\text { Native in neotropics, incl. } \\
\text { Caribbean; naturalized and } \\
\text { cultivated in tropics worldwide }\end{array}$ \\
\hline
\end{tabular}


Table 1 - (continued)

\begin{tabular}{|c|c|c|c|c|}
\hline Scientific Name & Family $^{1}$ & Local Name(s) & Plant Part & Distribution / Native Range $^{2}$ \\
\hline Cissampelos pareira $\mathrm{L}$. & Menispermaceae & pataçon & root & $\begin{array}{l}\text { Native range from Mexico to } \\
\text { Argentina and incl. Caribbean }\end{array}$ \\
\hline Citrus x aurantium L. & Rutaceae & sour orange & fruit peel & $\begin{array}{l}\text { Widely cultivated in tropics and } \\
\text { subtropics; hybrid }(C \text {. reticulata } \mathrm{x} C \text {. } \\
\text { maxima })^{3} \text { originating in China }\end{array}$ \\
\hline Coccinia grandis (L.) Voigt. & Cucurbitaceae & $\begin{array}{l}\text { parwar/ wild } \\
\text { cucumber/ ivy } \\
\text { gourd }\end{array}$ & leaf juice & $\begin{array}{l}\text { Native to Asia, African tropics and } \\
\text { Australia; naturalized in Fiji; } \\
\text { cultivated elsewhere }\end{array}$ \\
\hline Cocos nucifera $\mathrm{L}$. & Arecaceae & coconut & shell, flower & $\begin{array}{l}\text { Native to parts of tropical Asia } \\
\text { (including South East Asian islands } \\
\text { and South margin of India), Pacific } \\
\text { and Australia; widely naturalized and } \\
\text { cultivated }\end{array}$ \\
\hline $\begin{array}{l}\text { Cola nitida (Vent.) Schott \& } \\
\text { Endl. }\end{array}$ & Malvaceae & obie seed & seed & $\begin{array}{l}\text { Native to West African tropics; } \\
\text { cultivated elsewhere }\end{array}$ \\
\hline $\begin{array}{l}\text { Colubrina arborescens (Mill.) } \\
\text { Sarg. }\end{array}$ & Rhamnaceae & mauby & bark & $\begin{array}{l}\text { Native to Central and North America } \\
\text { (N.B. localized to south Florida), and } \\
\text { the Caribbean }\end{array}$ \\
\hline $\begin{array}{l}\text { Cordia curassavica (Jacq.) } \\
\text { Roem. \& Schult. }\end{array}$ & Boraginaceae & black sage & not specified & $\begin{array}{l}\text { Native range from Mexico to } \\
\text { Argentina and incl. Caribbean }\end{array}$ \\
\hline $\begin{array}{l}\text { Cymbopogon citratus (DC.) } \\
\text { Stapf }\end{array}$ & Poaceae & fever grass & not specified & $\begin{array}{l}\text { Originated in SE Asia; naturalized in } \\
\text { Argentina and Chile; cultivated } \\
\text { elsewhere. }\end{array}$ \\
\hline
\end{tabular}


Table 1 - (continued)

\begin{tabular}{|c|c|c|c|c|}
\hline Scientific Name & Family ${ }^{1}$ & Local Name(s) & Plant Part & Distribution / Native Range $^{2}$ \\
\hline Eryngium foetidum $\mathrm{L}$. & Apiaceae & $\begin{array}{l}\text { bandhaniya/ fit } \\
\text { weed/shado beni }\end{array}$ & leaves, roots & $\begin{array}{l}\text { Native to Central and South America } \\
\& \text { the Caribbean; naturalized } \\
\text { elsewhere including N. America } \\
\text { (Dade county, Florida) }\end{array}$ \\
\hline Gomphrena globosa L. & Amaranthaceae & bachelor button & leaves & $\begin{array}{l}\text { Widely cultivated \& naturalized, } \\
\text { exact native range obscure; probable } \\
\text { origin -Neotropics }\end{array}$ \\
\hline Ipomoea aquatica Forssk. & Convolvulaceae & kharmi bhaji & $\begin{array}{l}\text { leaves and } \\
\text { tender stems }\end{array}$ & $\begin{array}{l}\text { Native to S.E. Asia (Austin 2007) } \\
\text { naturalized elsewhere including the } \\
\text { Americas and the Pacific; widely } \\
\text { cultivated }\end{array}$ \\
\hline Laportea aestuans (L.) Chew & Urticaceae & stinging nettle & leaves & $\begin{array}{l}\text { Native to tropics in Africa and } \\
\text { America, incl. Caribbean; } \\
\text { naturalized elsewhere }\end{array}$ \\
\hline $\begin{array}{l}\text { Leonotis nepetifolia (L.) R. } \\
\quad \mathrm{Br} .\end{array}$ & Lamiaceae & shandilay & not specified & $\begin{array}{l}\text { Originated in tropical Africa; } \\
\text { naturalized across pantropics }\end{array}$ \\
\hline Momordica charantia $\mathrm{L}$. & Cucurbitaceae & coraillee/ caraaili & leaves, fruit & $\begin{array}{l}\text { Native to Africa, Asia and Australia; } \\
\text { naturalized in American tropics; } \\
\text { widely cultivated }\end{array}$ \\
\hline
\end{tabular}


Table 1 - (continued)

\begin{tabular}{|c|c|c|c|c|}
\hline Scientific Name & Family $^{1}$ & Local Name(s) & Plant Part & Distribution / Native Range ${ }^{2}$ \\
\hline Moringa oleifera Lam. & Moringaceae & saijan & leaves & $\begin{array}{l}\text { Native to Indian subcontinent; } \\
\text { cultivated elsewhere }\end{array}$ \\
\hline Morus alba $\mathrm{L}$. & Moraceae & pawi bush & not specified & $\begin{array}{l}\text { Native to temperate Asia; widely } \\
\text { naturalized and cultivated in } \\
\text { temperate and tropical areas }\end{array}$ \\
\hline Musa $\mathrm{x}$ paradisiaca $\mathrm{L}$. & Musaceae & silk fig & leaves & $\begin{array}{l}\text { Indo/Malaysian origin; widely } \\
\text { cultivated }\end{array}$ \\
\hline $\begin{array}{l}\text { Neurolaena lobata (L.) R.Br. } \\
\quad \text { ex Cass. }\end{array}$ & Asteraceae & $\begin{array}{l}\text { zeb-a-pik/ } \\
\text { zebapique }\end{array}$ & leaves & $\begin{array}{l}\text { Native to American tropics, incl. } \\
\text { Caribbean }\end{array}$ \\
\hline Passiflora quadrangularis L. & Passifloraceae & $\begin{array}{l}\text { barbadine/ } \\
\text { granadilla }\end{array}$ & leaves & $\begin{array}{l}\text { Originated in neotropics; widely } \\
\text { cultivated in the tropics }\end{array}$ \\
\hline Persea americana Mill. & Lauraceae & zaboca/avocado & seed & $\begin{array}{l}\text { Originated in Central America - } \\
\text { Mexico \& Guatemala; naturalized in } \\
\text { Pacific. }\end{array}$ \\
\hline $\begin{array}{l}\text { Phyllanthus amarus } \\
\text { Schumach. \& Thonn. }\end{array}$ & Phyllanthaceae & seed-under-leaf & not specified & $\begin{array}{l}\text { Native to tropical America, incl. } \\
\text { Caribbean; naturalized in } \\
\text { paleotropics }\end{array}$ \\
\hline
\end{tabular}


Table 1 - (continued)

\begin{tabular}{|c|c|c|c|c|}
\hline Scientific Name & Family $^{1}$ & Local Name(s) & Plant Part & Distribution / Native Range $^{2}$ \\
\hline Phyllanthus urinaria L. & Phyllanthaceae & seed-under-leaf & not specified & $\begin{array}{l}\text { Native to temperate and tropical } \\
\text { regions in Asia as well as the western } \\
\text { Pacific; naturalized elsewhere in the } \\
\text { tropics }\end{array}$ \\
\hline $\begin{array}{l}\text { Pityrogramma calomelanos } \\
\text { (L.) Link }\end{array}$ & Pteridaceae & stamp fern & whole plant & $\begin{array}{l}\text { Native to neotropics, incl. } \\
\text { Caribbean; naturalized in } \\
\text { paleotropics }\end{array}$ \\
\hline Ruellia tuberosa L. & Acanthaceae & minny root & root, leaves & $\begin{array}{l}\text { Native to Central America; } \\
\text { naturalized in South America \& } \\
\text { Caribbean and across paleotropics }\end{array}$ \\
\hline Scoparia dulcis L. & Plantaginaceae & sweet broom & whole herb & $\begin{array}{l}\text { Neotropical origin; widely naturalized } \\
\text { in tropics and subtropics }\end{array}$ \\
\hline $\begin{array}{l}{ }^{5} \text { Senna fruticosa (Mill.) H.S. } \\
\text { Irwin \& Barneby }\end{array}$ & Fabaceae & christmas bush & flowers & $\begin{array}{l}\text { Native to Mexico and Central } \\
\text { America, excl. Caribbean }\end{array}$ \\
\hline${ }^{5}$ Senna italica Mill. & Fabaceae & senna & not specified & $\begin{array}{l}\text { Native to Africa, tropical and } \\
\text { temperate regions in Asia; naturalized } \\
\text { in Venezuela }\end{array}$ \\
\hline
\end{tabular}


Table $1-$ (continued)

\begin{tabular}{|c|c|c|c|c|}
\hline Scientific Name & Family ${ }^{1}$ & Local Name(s) & Plant Part & Distribution / Native Range $^{2}$ \\
\hline Spermacoce verticillata $\mathrm{L}$. & Rubiaceae & white head broom & whole herb & $\begin{array}{l}\text { Native in neotropics from Mexico to } \\
\text { Paraguay; incl. the Caribbean; } \\
\text { naturalized elsewhere }\end{array}$ \\
\hline $\begin{array}{l}\text { Spiranthes acaulis (Sm.) } \\
\text { Cogn. }\end{array}$ & Orchidaceae & lapsogen & not specified & $\begin{array}{l}\text { Native in Central to South America } \\
\text { and Trinidad and Tobago }\end{array}$ \\
\hline Spondias mombin L. & Anacardiaceae & hog plum & leaves & $\begin{array}{l}\text { Native to tropical America; obscure } \\
\text { native range in West Indies; widely } \\
\text { cultivated in paleotropics }\end{array}$ \\
\hline $\begin{array}{l}\text { Stachytarpheta jamaicensis } \\
\text { (L.) Vahl }\end{array}$ & Verbenaceae & vervine/ vervain & not specified & $\begin{array}{l}\text { Native to American tropics, incl. } \\
\text { Caribbean; widely naturalized in } \\
\text { paleotropics \& Polynesia }\end{array}$ \\
\hline
\end{tabular}

1. Listing of Family names based on information from Stevens (2001) and The Plant List (2013)

2. Unless indicated otherwise, places of origin / distribution ranges were sourced from GRIN (2016) and Tropicos (2016)

3. IPNI (2012) entry for Citrus aurantium L. indicates probable hybrid of C. maxima x C. reticulata

4. Austin 2007, states that Ipomoea aquatica originated in S.E. Asia (includes China \& India) but was introduced elsewhere.

5. Originally listed as Cassia spp, these species have been assigned to the genus Senna based on shared floral morphology as described in Irwin and Barneby 1982. 
Figure 2 - Modern political map of African continent showing West African countries (in red) from which slaves were conscripted and sent to Trinidad and Tobago. (Map of Africa inset with corresponding regions shaded)

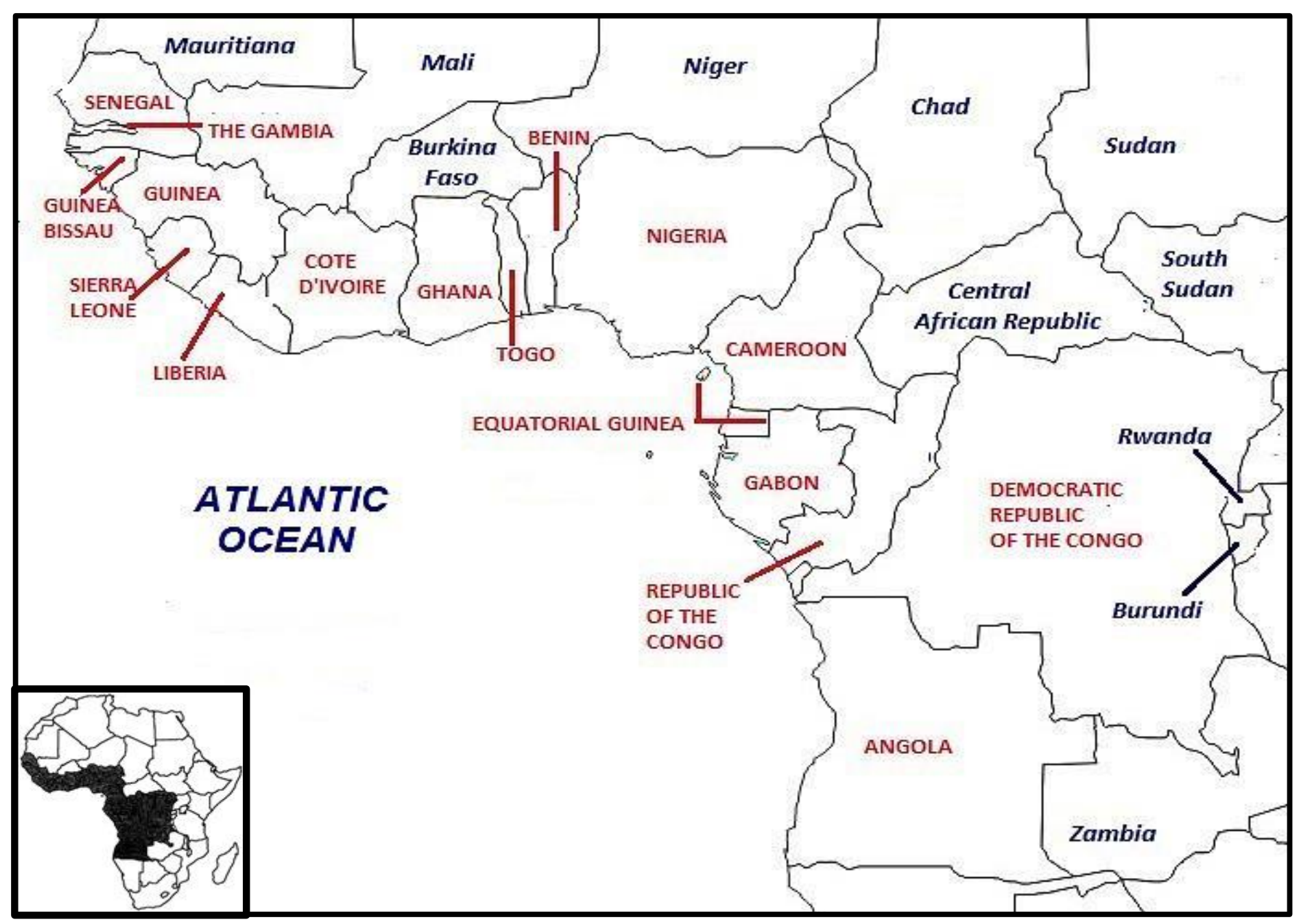


Figure 3 - Map of India showing location of countries, states and cities of interest with dated (1981) names

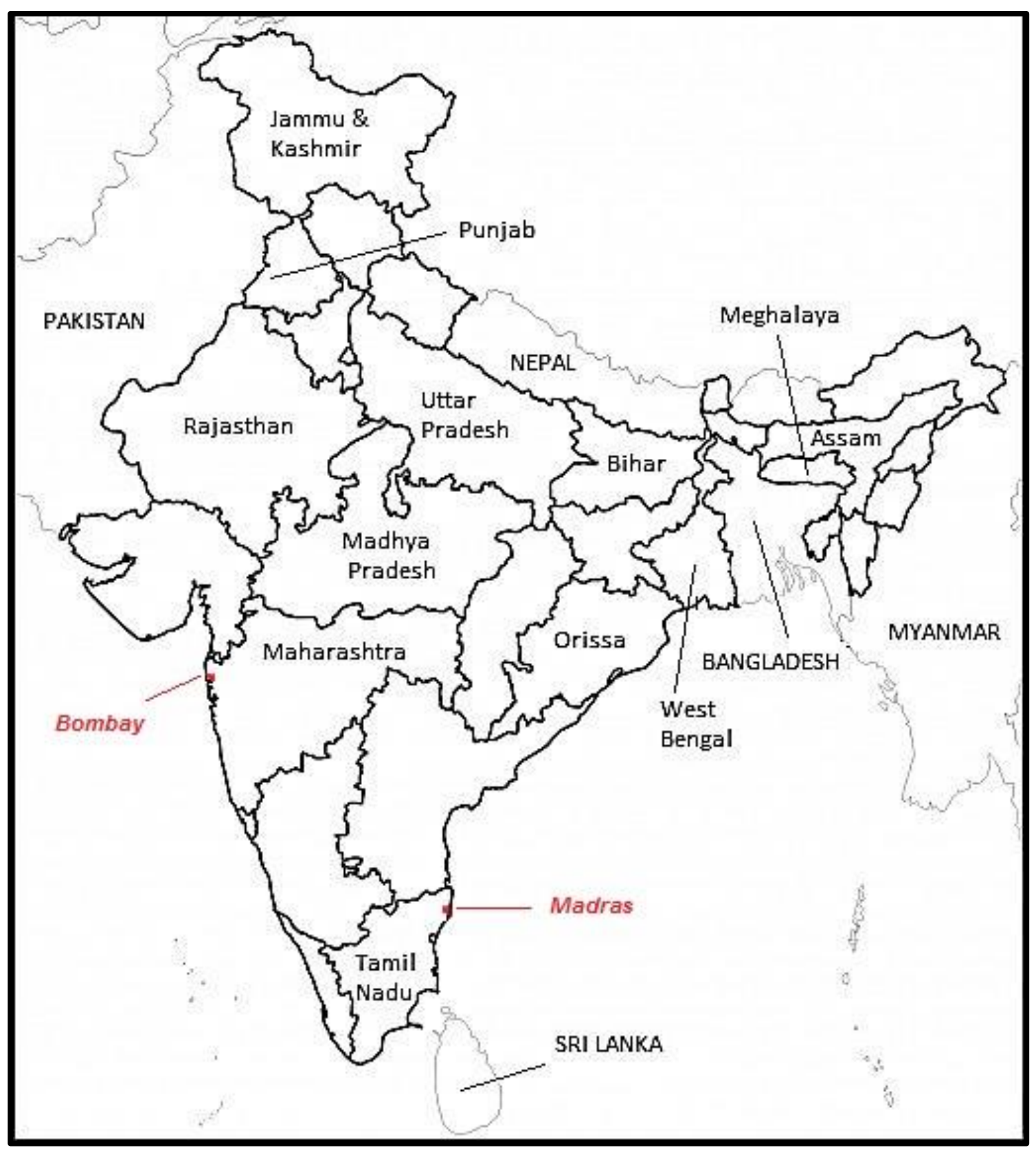


Table 2 - Countries or Regions on African continent from which slaves arrived in Trinidad and Tobago with corresponding list of current names. (Eltis and Richardson 2010).

\begin{tabular}{|ll|}
\hline Historic Name of Country/Region & Current Name(s) of Country/Region \\
\hline Bight of Benin & Togo, Benin and Nigeria \\
Bight of Biafra & Nigeria, Cameroon, Equatorial Guinea and \\
& Gabon \\
Gold Coast & Ghana \\
Senegambia & Senegal, The Gambia, Guinea-Bissau \\
Sierra Leone & Guinea and Sierra Leone \\
West Central Africa & Republic of Congo and Angola \\
Windward Coast & Liberia and Cote D'Ivoire \\
\hline
\end{tabular}

Table 3 - Regions of the Indian sub-continent from which indentured laborers were sourced (Weller 1968, p. 125), with corresponding list of recent (1981) names.

\begin{tabular}{|ll|}
\hline Historic Name of Region & Recent Name(s) of Cities/States/COUNTRIES \\
\hline Bengal & West Bengal and Bihar \\
Bihar & Bihar \\
United Provinces of Agra and Oudh & Uttar Pradesh \\
Central Provinces and Central India & Madhya Pradesh \\
Punjab & Punjab and Pakistan \\
Bombay and Madras & Bombay (Maharashtra) \& Madras (Tamil Nadu) \\
North-West Frontier Provinces & PAKISTAN \\
East Bengal and Assam & BANGLADESH, Meghalaya and Assam \\
Nepal & NEPAL \\
Rajputana & Rajasthan \\
\hline
\end{tabular}


Table 4 - Trinidad and Tobago antidiabetics shared with western Africa

\begin{tabular}{|lllll|}
\hline Scientific Name & Family & Plant Part & Country/Sub region & Reference \\
\hline $\begin{array}{l}\text { Aristolochia } \text { sp. } \\
\text { Carica papaya } \text { L. }\end{array}$ & Aristolochiaceae & Not specified & Not specified & 2 \\
$\begin{array}{l}\text { Catharanthus roseus } \text { (L.) } \\
\text { G. Don }\end{array}$ & Caricaceae & Not specified & Nigeria & 3 \\
$\begin{array}{l}\text { Coccinia } \text { sp. } \\
\text { Ipomoea aquatica } \text { Forskk. }\end{array}$ & Convulvulaceae & Not specified & Not specified & 2,4 \\
Momordica spp. & Cucurbitaceae & Fruit & Not specified & 2 \\
Morus spp. & Moraceae & Leaves & Not specified & $1,2,4$ \\
Musa sp. & Musaceae & Fruit, Flowers & Not specified & 2,4 \\
Phyllanthus sp. & Phyllanthaceae & Leaves & Not specified & 1,4 \\
Scoparia dulcis L. & Plantaginaceae & Whole Plant & Not specified & 4 \\
Senna sp. & Fabaceae & Not specified & Not specified & 4 \\
\hline
\end{tabular}

List of References by numbers indicated in Table 4:

(1) Ayensu 1978; (2) Iwu 1993; (3) Iwu 1994; (4) Oliver-Bever 1986. 
Table 5 - Trinidad and Tobago antidiabetics shared with India

\begin{tabular}{|c|c|c|c|c|}
\hline Scientific Name & Family & Plant Part & Country/Sub region & Reference \\
\hline Abrus precatorius L. & Fabaceae & Leaves (Juice) & Tamilnadu & 1 \\
\hline Aloe sp. & Xanthorrhoeaceae & Leaves & West Bengal & 3 \\
\hline Annona sp. & Annonaceae & Leaves & Tamilnadu, West Bengal & 1,3 \\
\hline Aristolochia sp. & Aristolochiaceae & Leaves & Tamilnadu & 1 \\
\hline $\begin{array}{l}\text { Azadirachta indica A. } \\
\text { Juss. }\end{array}$ & Meliaceae & $\begin{array}{l}\text { Buds, Flowers, Bark, } \\
\text { Leaves, Fruits, Seeds, } \\
\text { Stem/Bark juice, Leaf } \\
\text { paste }\end{array}$ & $\begin{array}{l}\text { Tamilnadu, Orissa, Bihar, } \\
\text { West Bengal, Punjab \& } \\
\text { other unspecified regions }\end{array}$ & $\begin{array}{l}1,2,3,5,7,9,11, \\
12 .\end{array}$ \\
\hline Carica papaya L. & Caricaceae & Green Fruit & Tamilnadu & 1 \\
\hline $\begin{array}{l}\text { Catharanthus roseus (L.) } \\
\text { G. Don }\end{array}$ & Apocynaceae & $\begin{array}{l}\text { Leaves, Flowers, } \\
\text { Roots, Whole Plant }\end{array}$ & $\begin{array}{l}\text { West Bengal \& other } \\
\text { unspecified regions }\end{array}$ & $3,4,9$ \\
\hline Cissampelos pareira $\mathrm{L}$. & Menispermaceae & Root powder & Not specified & 9 \\
\hline Citrus sp. & Rutaceae & Fruit juice & West Bengal & 3 \\
\hline Coccinia spp. & Cucurbitaceae & $\begin{array}{l}\text { Fruits, Leaf Juice, } \\
\text { Roots, Mucilage of } \\
\text { young fruit, Whole } \\
\text { Plant }\end{array}$ & $\begin{array}{l}\text { West Bengal, Tamilnadu \& } \\
\text { other unspecified regions }\end{array}$ & $1,3,4,9,12$ \\
\hline Cocos nucifera L. & Arecaceae & Male Flower & Tamilnadu & 1 \\
\hline Ipomoea sp. & Convolvulaceae & Root paste & Orissa & 10 \\
\hline Momordica charantia L. & Cucurbitaceae & Whole Plant, Fruit & $\begin{array}{l}\text { West Bengal \& other } \\
\text { unspecified regions }\end{array}$ & $3,9,12$ \\
\hline
\end{tabular}


Table 5 (continued)

\begin{tabular}{|lllll|}
\hline Scientific Name & Family & Plant Part & Country/Sub region & Reference \\
\hline Moringa oleifera Lam. & Moringaceae & Fruit & Tamilnadu & 1 \\
Musa spp. & Musaceae & Flowers, Fruit & $\begin{array}{l}\text { West Bengal \& unspecified } \\
\text { region }\end{array}$ & 3,4 \\
$\begin{array}{l}\text { Phyllanthus amarus } \\
\text { Schumach. \& Thonn. }\end{array}$ & Phyllanthaceae & Whole Plant & Not Specified & 12 \\
$\begin{array}{l}\text { Scoparia dulcis L. } \\
\text { Plantaginaceae }\end{array}$ & Leaves, Whole Plant & $\begin{array}{l}\text { West Bengal \& unspecified } \\
\text { region }\end{array}$ & 3,4 \\
${ }^{1}$ Senna spp. & Fabaceae & Flowers, Buds & West Bengal, Tamilnadu, & $1,3,4,6,8,9,12$ \\
& & $\begin{array}{l}\text { Stem/Bark, Leaves } \\
\text { Fruit pulp, Seeds } \\
\text { (ground) }\end{array}$ & $\begin{array}{l}\text { Sind, Bihar \& other } \\
\text { unspecified regions }\end{array}$ \\
& & &
\end{tabular}

1. Originally listed as Cassia, these species have been assigned to the genus Senna based on shared floral morphology as described in Irwin and Barneby 1982.

List of references by numbers indicated in Table 5: (1) Balu et al. 1999; (2) Dash and Misra 1999; (3) Ghosh and Das 1999; (4) Jain and de Filipps 1991; (5) Kumar and Goel in Maheshwari 2000; (6) Murray 1989; (7) Panda and Das in Maheshwari 2000; (8) Paul 1977; (9) Rana et al. 1999; (10) Saxena et al. 1981; (11) Shah 1982; (12) Sivarajan and Balachandran 1994. 
Table 6 - Trinidad and Tobago (T\&T) antidiabetic species/genera shared with Caribbean Basin countries/regions

\begin{tabular}{|c|c|c|c|c|}
\hline Scientific Name & Family & Plant Part & Country/Region & Reference \\
\hline Aloe spp. & Xanthorrhoeaceae & leaf & $\begin{array}{l}\text { Dominican Republic, } \\
\text { Guatemala, Jamaica, Martinique, } \\
\text { Montserrat, Yucatan }\end{array}$ & $\begin{array}{l}4,10,7,12,20 \\
27,28\end{array}$ \\
\hline Annona muricata $\mathrm{L}$. & Annonaceae & leaf & Honduras, Yucatan & 4,14 \\
\hline Aristolochia spp. & Aristolochiaceae & leaf & Jamaica, Venezuela, Yucatan & $4,23,27$ \\
\hline $\begin{array}{l}\text { Artocarpus altilis (Parkinson } \\
\text { ex F.A.Zorn) Fosberg }\end{array}$ & Moraceae & leaf, fruit & Guyana, Jamaica, Martinique, & $18,20,27$ \\
\hline Azadirachta indica A. Juss & Meliaceae & leaf & Guyana, Suriname & 18,21 \\
\hline Bidens spp. & Asteraceae & whole plant & $\begin{array}{l}\text { Colombia, Guyana, Martinique, } \\
\text { Venezuela, Yucatan }\end{array}$ & $14,18,20,30,31$ \\
\hline Bixa orellana $\mathrm{L}$. & Bixaceae & root & Guatemala, Jamaica & 12,22 \\
\hline Bontia daphnoides $L$. & Scrophulariaceae & leaf & Martinique & 20 \\
\hline Cajanus cajun (L.) Millsp. & Fabaceae & leaf and flower & Guyana, Puerto Rico & 6,18 \\
\hline Cannabis sativa $\mathrm{L}$. & Cannabaceae & not specified & Jamaica & 22 \\
\hline Carica papaya L. & Caricaceae & young fruit & Guyana & 18 \\
\hline $\begin{array}{l}\text { Catharanthus roseus (L.) G. } \\
\text { Don (syn. Vinca rosea L.) }\end{array}$ & Apocynaceae & $\begin{array}{l}\text { leafy stem, leaf, } \\
\text { whole plant, } \\
\text { flower }\end{array}$ & $\begin{array}{l}\text { Belize, Dominica (Comm.), } \\
\text { Guyana, Jamaica, Montserrat, } \\
\text { Martinique, Suriname, Turks \& } \\
\text { Caicos, Yucatan }\end{array}$ & $\begin{array}{l}2,3,4,11,16,18 \\
20,21,27,31\end{array}$ \\
\hline Chromolaena odorata L. & Asteraceae & root & Jamaica, Yucatan & 1,27 \\
\hline
\end{tabular}


Table 6 (continued)

\begin{tabular}{|c|c|c|c|c|}
\hline Scientific Name & Family & Plant Part & Country/Region & Reference \\
\hline Citrus spp. & Rutaceae & $\begin{array}{l}\text { fruit peel, raw } \\
\text { fruit, fruit juice }\end{array}$ & $\begin{array}{l}\text { Dominican Republic, Haiti, } \\
\text { Martinique, Venezuela }\end{array}$ & $10,20,23,27$ \\
\hline Cocos nucifera L. & Arecaceae & $\begin{array}{l}\text { kernel or } \\
\text { endosperm, fruit, } \\
\text { shell }\end{array}$ & $\begin{array}{l}\text { Belize, Jamaica, Martinique, } \\
\text { Nicaragua }\end{array}$ & $2,5,20,22$ \\
\hline $\begin{array}{l}\text { Cymbopogon citratus (DC.) } \\
\text { Stapf }\end{array}$ & Poaceae & leaves & Puerto Rico & 6 \\
\hline Eryngium foetidum $L$. & Apiaceae & leaves & Honduras, Jamaica, Puerto Rico & $6,14,28$ \\
\hline Leonotis nepetifolia (L.) R. Br. & Lamiaceae & leaf & Martinique & 20 \\
\hline Momordica charantia $\mathrm{L}$. & Cucurbitaceae & $\begin{array}{l}\text { leafy vine, stem, } \\
\text { leaf, fruit, root, } \\
\text { whole plant }\end{array}$ & $\begin{array}{l}\text { Bahamas, Belize, Colombia, } \\
\text { Costa Rica, Dominican } \\
\text { Republic, Guatemala, Guyana, } \\
\text { Honduras, Jamaica, Martinique, } \\
\text { Montserrat, Nicaragua, Panama, } \\
\text { Puerto Rico, Suriname, } \\
\text { Venezuela }\end{array}$ & $\begin{array}{l}2,5,6,7,12,13, \\
14,15,17,18,20 \\
21,25,26,28,29 \\
31\end{array}$ \\
\hline Morus spp. & Moraceae & leaf & Puerto Rico & 6,26 \\
\hline Musa spp. & Musaceae & not specified & Dominican Republic & 10 \\
\hline $\begin{array}{l}\text { Neurolaena lobata (L.) R.Br. } \\
\text { ex Cass. }\end{array}$ & Asteraceae & leaf & $\begin{array}{l}\text { Cost Rica, Guatemala, } \\
\text { Nicaragua, Panama }\end{array}$ & $5,12,14$ \\
\hline Passiflora quadrangularis L. & Passifloraceae & leaf & Dominican Republic, Martinique & 10,20 \\
\hline
\end{tabular}


Table 6 (continued)

\begin{tabular}{|c|c|c|c|c|}
\hline Scientific Name & Family & Plant Part & Country/Region & Reference \\
\hline Persea americana Mill. & Lauraceae & leaf & $\begin{array}{l}\text { Dominican Republic, Haiti, } \\
\text { Martinique, Yucatan }\end{array}$ & $4,8,10,19,20$ \\
\hline Phyllanthus spp. & Phyllanthaceae & $\begin{array}{l}\text { leaf, seed, root, } \\
\text { whole plant }\end{array}$ & $\begin{array}{l}\text { Cuba, Guyana, Haiti, Jamaica, } \\
\text { Martinique, Puerto Rico, } \\
\text { Suriname }\end{array}$ & $\begin{array}{l}3,18,19,20,21 \\
26,30\end{array}$ \\
\hline Ruellia tuberosa L. & Acanthaceae & roots & Suriname & 21 \\
\hline Scoparia dulcis L. & Plantaginaceae & whole plant & Guyana & 18 \\
\hline Senna spp. & Fabaceae & $\begin{array}{l}\text { leaf, whole plant, } \\
\text { seeds, root }\end{array}$ & $\begin{array}{l}\text { Belize, Cuba, Guatemala, } \\
\text { Guyana, Jamaica }\end{array}$ & $2,12,18,22,30$ \\
\hline Spondias spp. & Anacardiaceae & fruit & Jamaica, Suriname & 21,22 \\
\hline $\begin{array}{l}\text { Stachytarpheta jamaicensis } \\
\text { (L.) Vahl. }\end{array}$ & Verbenaceae & whole plant & Guyana, Suriname & $11,18,21$ \\
\hline
\end{tabular}

List of references by numbers indicated in Table 6

(1) Ankli, et al. 1999; (2) Arvigo \& Balick 1993; (3) Asprey \& Thornton 1953; (4) Balam Pereira 1992; (5) Barrett 1994; (6) Benedetti 2000; (7) Brussell 1997; (8) Brutus \& Pierre-Noel 1960; (9) Comerford 1996; (10) Estevex \& Baez 1998; (11) Feng, 1956; (12) Giron, et al. 1991; (13) Gupta, et al. 1979; (14) Gupta 1995; (15) Halberstein \& Saunders 1978; (16) Hodge \& Taylor, 1957; (17) House, et al. 1990; (18) Lachman-White, et al. 1992; (19) Leon 1959; (20) Longuefosse \& Nossin 1996; (21) Mans 2012; (22) Morrison \& West 1982; (23) Morton 1975; (24) Morton 1977; (25) Nunez Melendez 1978; (26) Nunez Melendez 1982; (27) Paul \& Cox 1995; (28) Payne-Jackson \& Alleyne 2004; (29) Rodriguez Martinez 1999; (30) Roig 1945; (31) Roth \& Lindorf 2002; (32) van Andel 2000. 
Table 7 - Antidiabetic Species Similarity Indices for Caribbean Basin locations in relation to Trinidad and Tobago (T\&T)

\begin{tabular}{|c|c|c|c|c|}
\hline Country or Region & $\begin{array}{l}\text { Number of Shared } \\
\text { Antidiabetic Species }\end{array}$ & $\begin{array}{l}\text { Number of Unique } \\
\text { Antidiabetic Species }\end{array}$ & $\begin{array}{l}\text { Percentage } \\
\text { Similarity }\end{array}$ & $\begin{array}{c}\text { Jaccard } \\
\text { Index of } \\
\text { Similarity }\end{array}$ \\
\hline Bahamas & 1 & 0 & $2.1 \%$ & $2.1 \%$ \\
\hline Belize & 3 & 6 & $6.3 \%$ & $5.6 \%$ \\
\hline Colombia & 2 & 4 & $4.2 \%$ & $3.8 \%$ \\
\hline Costa Rica & 2 & 5 & $4.2 \%$ & $3.8 \%$ \\
\hline Cuba & 1 & 8 & $2.1 \%$ & $1.8 \%$ \\
\hline Curacao & 0 & 3 & 0 & 0 \\
\hline Dominica (Commonwealth of) & 1 & 0 & $2.1 \%$ & $2.1 \%$ \\
\hline Dominican Republic & 5 & 19 & $10.4 \%$ & $7.5 \%$ \\
\hline Guadeloupe & 0 & 3 & 0 & 0 \\
\hline Guatemala & 4 & 7 & $8.3 \%$ & $7.3 \%$ \\
\hline Guyana & 11 & 11 & $22.9 \%$ & $18.6 \%$ \\
\hline Haiti & 2 & 15 & $4.2 \%$ & $3.2 \%$ \\
\hline Honduras & 3 & 1 & $6.3 \%$ & $6.1 \%$ \\
\hline Jamaica & 10 & 11 & $20.8 \%$ & $16.9 \%$ \\
\hline Montserrat & 3 & 4 & $6.3 \%$ & $5.8 \%$ \\
\hline Martinique & 12 & 14 & $25 \%$ & $19.4 \%$ \\
\hline Nicaragua & 3 & 1 & $6.3 \%$ & $6.1 \%$ \\
\hline Panama & 2 & 4 & $4.2 \%$ & $3.8 \%$ \\
\hline Puerto Rico & 4 & 9 & $8.3 \%$ & $7.0 \%$ \\
\hline Suriname & 5 & 10 & $10.4 \%$ & $8.6 \%$ \\
\hline Turks \& Caicos & 1 & 0 & $2.1 \%$ & $2.1 \%$ \\
\hline Venezuela & 2 & 25 & $4.2 \%$ & $2.7 \%$ \\
\hline Yucatan & 6 & 18 & $12.5 \%$ & $9.1 \%$ \\
\hline
\end{tabular}


Figure 4 - Social Network Analysis (SNA) graph of shared antidiabetic genera of the Caribbean Basin. (Squares - Countries; Circles - genera)

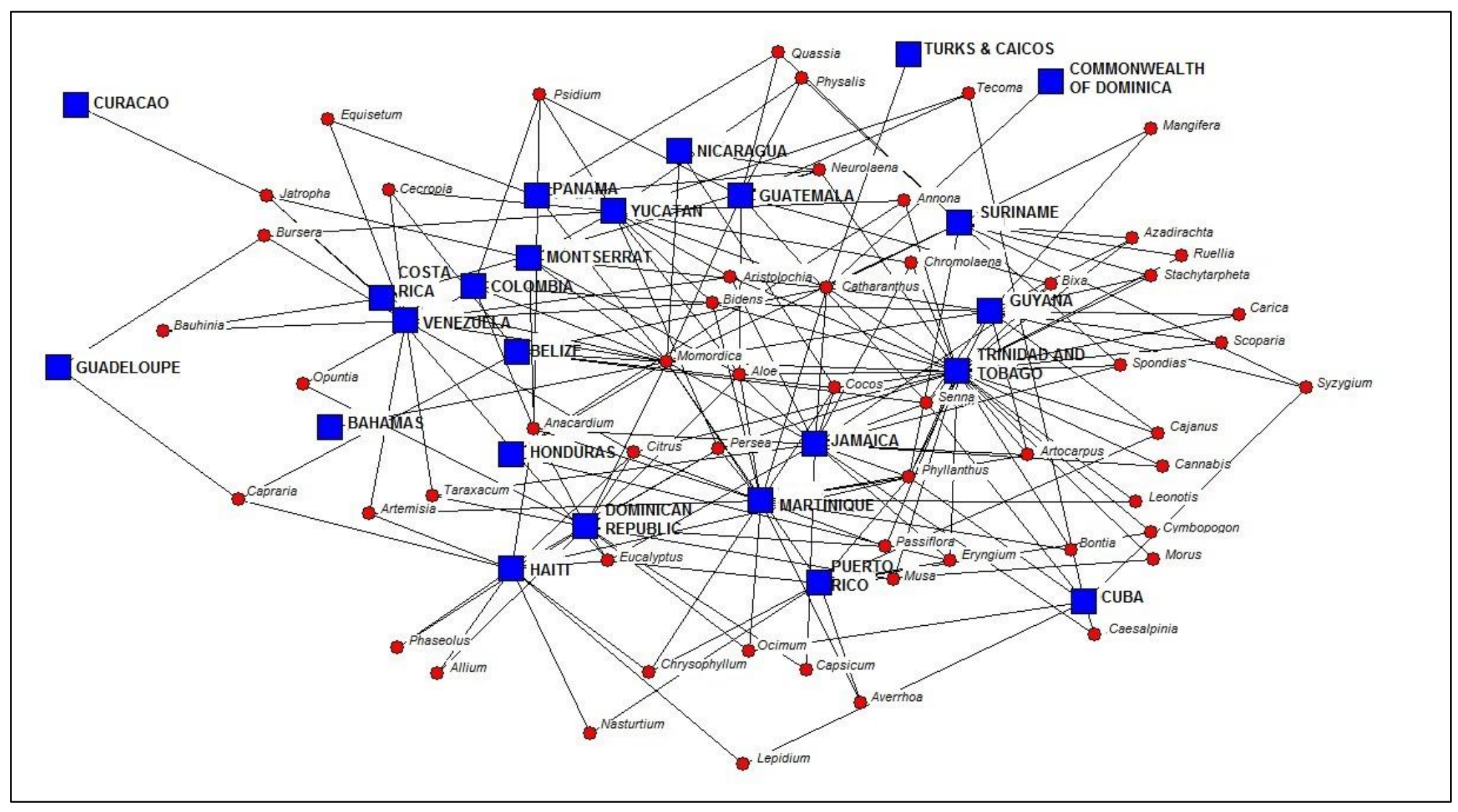


Figure 5 - Social Network Analysis (SNA) graph of shared antidiabetic genera of the Caribbean Basin showing language groupings. (Squares - Countries; Circles - genera)

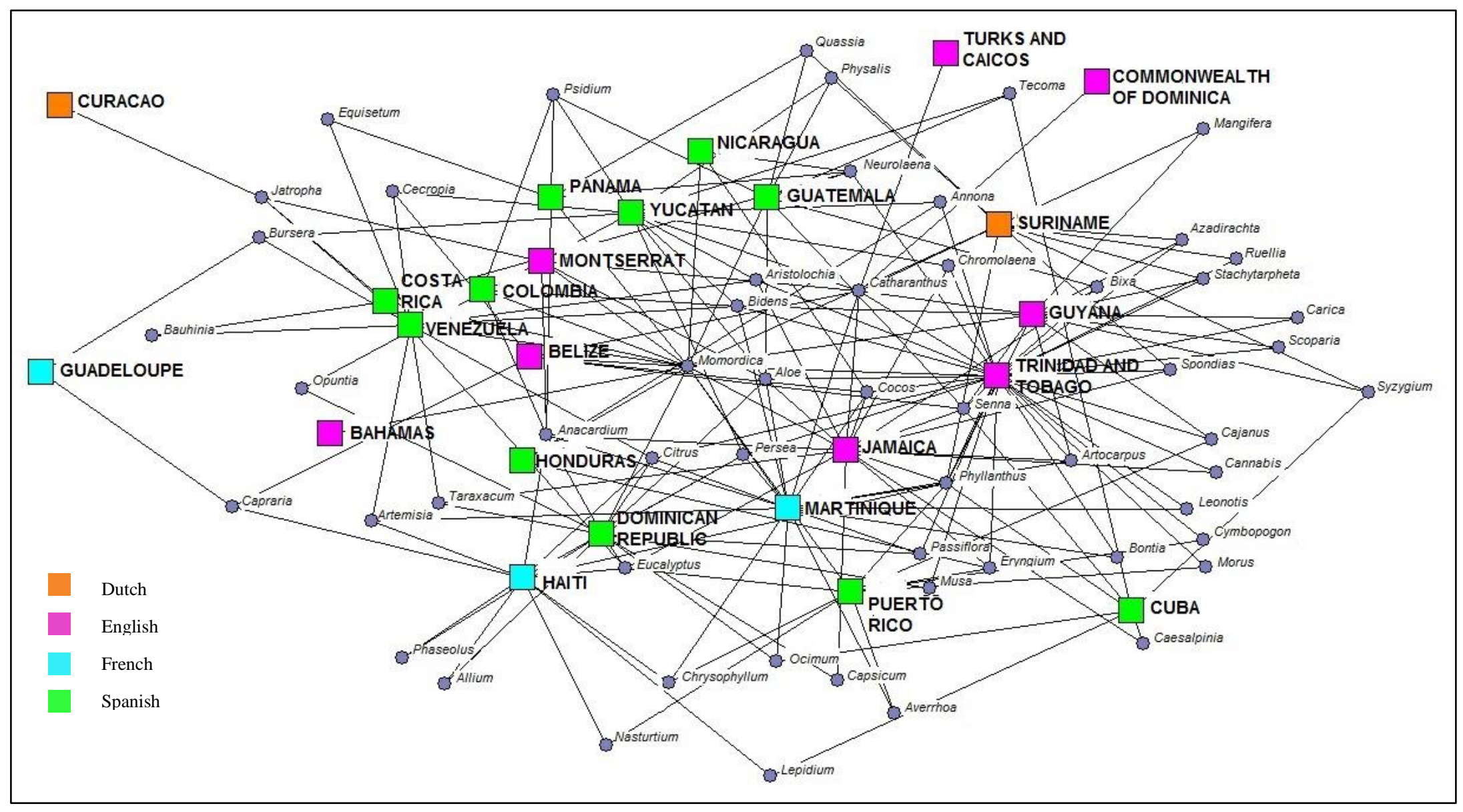


Figure 6 - Social Network Analysis (SNA) graph of shared antidiabetic genera of the Caribbean Basin showing locality groupings. (Squares - Countries; Circles - genera)

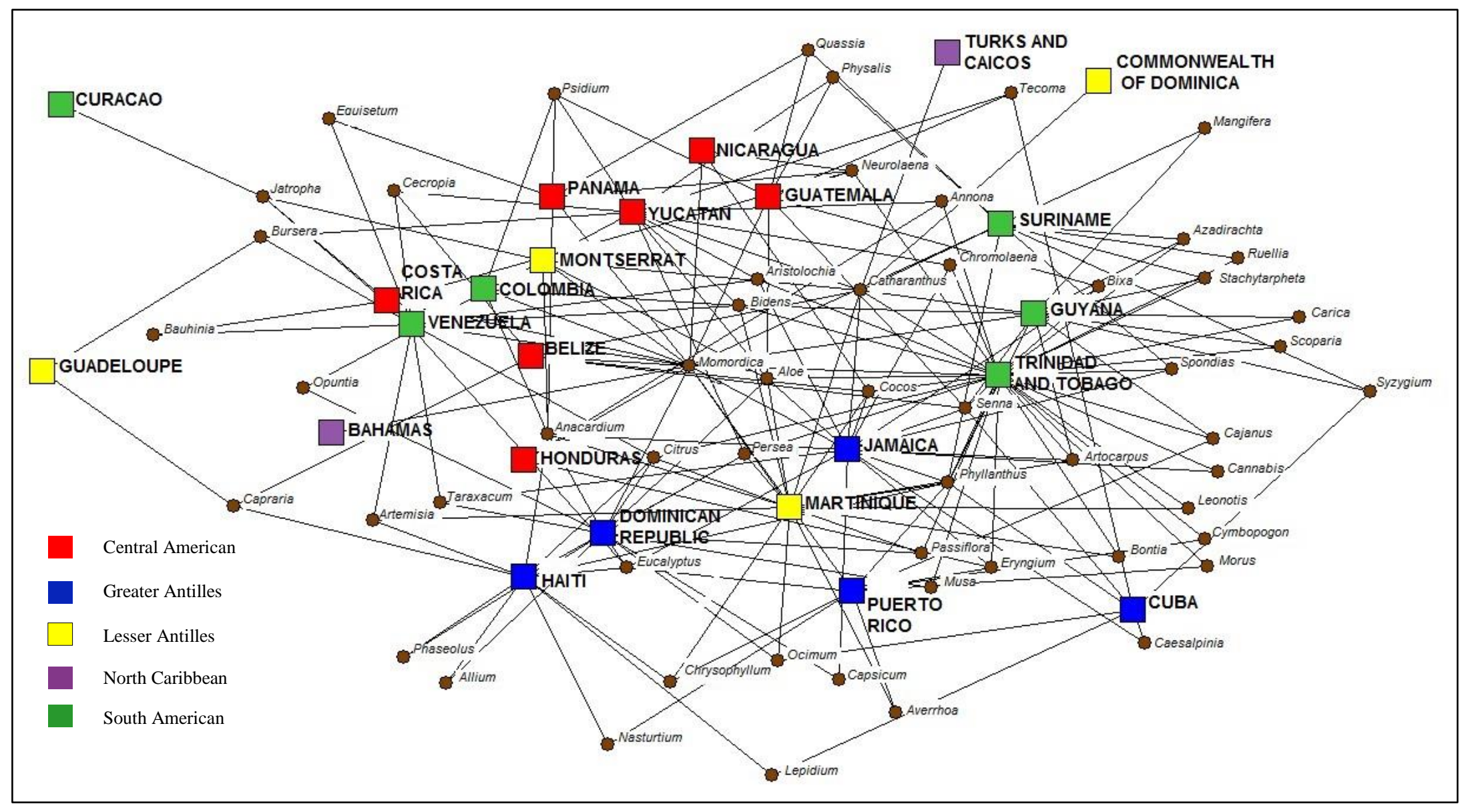




\section{LITERATURE CITED}

Ankli, A., Sticher, O., and M. Heinrich. 1999. Medical ethnobotany of the Yucatec Maya: Healers' consensus as a quantitative criterion. Economic Botany 53(2):144-160.

Anthony, M. 1975. Profile Trinidad: A Historical Survey from the Discovery to 1900. Macmillan Publishers, Hong Kong.

Arvigo, R. and M. Balick. 1993. Rainforest Remedies: One Hundred Healing Herbs of Belize. Lotus Press, Twin Lakes, WI.

Asprey, G. F. and P. Thornton. 1953. Medicinal Plants of Jamaica. Part I. West Indian Medical Journal 4:233-252.

Austin, D.F. 2007. Water spinach (Ipomoea aquatica, Convolvulaceae) a food gone wild. Ethnobotany Research and Applications 5:123-146.

Ayensu, E.S. 1978. Medicinal Plants of West Africa. Reference Publications, Algonac, MI.

Bailey, C.J. and C. Day. 1989. Traditional plant medicines as treatments for diabetes. Diabetes Care 12:553-564.

Bailey, C.J. and C. Day. 2004. Metformin: Its botanical background. Practical Diabetes International 21:115-117.

Balam Pereira, G. 1992. Cosmogonía Y Uso Actual de las Plantas Medicinales de Yucatán. Ediciones de la Universidad Autónoma de Yucatán, Mérida, Yucatan, México.

Balu, S., Alagesaboopathi, C. and S. Madhavan. 1999. Botanical Remedies for Diabetes from the Cauvery Delta of Tamil Nadu. Journal of Economic and Taxonomic Botany $23: 359-362$.

Barraclough, G. (ed.). 1978. The Times Atlas of world history. Hammond, Maplewood, NJ.

Barraclough, G. (ed.). 1988. The Times concise atlas of world history. Hammond, Maplewood, NJ.

Barrett, B. 1994. Medicinal plants of Nicaragua's Atlantic coast. Economic Botany 48(1):8-20.

Benedetti, M. D. H. 2000. Earth and spirit: Medicinal plants and healing lore from Puerto Rico. Verde Luz, Orocovis, P.R. 
Bennett, B. C., and G. T. Prance. 2000. Introduced Plants in the Indigenous

Pharmacopoeia of Northern South America. Economic Botany 54:90-102.

Bennett, B.C., Baker, M.A. and P.G. Andrade. 2002. Ethnobotany of the Shuar of Eastern Ecuador. Bronx: New York Botanical Garden Press.

Berry, M.V. 2005. Exploring the Potential Contributions of Amerindians to West Indian Folk Medicine. Southeastern Geographer 45:239-250.

Boomert, A. 2002. Amerindian-European Encounters on and around Tobago (1498-ca. 1810). Antropológica 97(98):71-207.

Borgatti, S.P. 2005. Centrality and network flow. Social Networks 27:55-71.

Borgatti, S.P., and M.G. Everett. 1997. Network analysis of 2-mode data. Social Networks 19:243-269.

Borgatti, S.P., Everett, M.G. and L.C. Freeman. 2002. UCINET for Windows: Software for social network analysis. Version 6.178. Harvard, MA: Analytic Technologies.

Brussell, D. E. 1997. Potions, poisons, and panaceas: An ethnobotanical study of Montserrat. Southern Illinois University Press, Carbondale, IL.

Brutus, T. C., and A.V. Pierre-Noel. 1960. Les Plantes et les Legumes d'Haiti qui Guerissent: mille et une recettes pratiques. Imprimerie de l'État, Puerto-Principis, Haiti.

Bryan, C. P. 1930. The Papyrus Ebers: translated from the German version. Garden City Press, Letchworth, Herts.

Clement, Y.N., Baksh-Comeau, Y.S. and C.E. Seaforth. 2015. An ethnobotanical survey of medicinal plants in Trinidad. Journal of Ethnobiology and Ethnomedicine 11(1):1.

Comerford, S. C. 1996. Medicinal Plants of Two Mayan Healers from San Andrés, Petén, Guatemala. Economic Botany 50(3):327-336.

Dash, S. S. and M.K. Misra. 1999. Taxonomic Survey \& Systematic Census of Economic Plants of Narayanapatna Hills of Koraput District, Orissa. Journal of Economic and Taxonomic Botany 23:473-498.

de Medeiros, P. M., Soldati, G. T., Alencar, N. L., Vandebroek, I., Pieroni, A., Hanazaki, N., and U.P. de Albuquerque. 2012. The use of medicinal plants by migrant people: adaptation, maintenance, and replacement. Evidence-based Complementary and Alternative Medicine, eCAM 2012:807452.

Eltis, D. and D. Richardson. 2010. Atlas of the Transatlantic Slave Trade. Yale University Press, New Haven, CT. 
Estévez M.A. and F. Báez. 1998. Plantas curativas: usos populares y cientificos. Caribe Soy, Santo Domingo.

Everett, M.G., and S.P. Borgatti. 2012. Categorical attribute based centrality: E-I and G-F centrality. Social Networks 34:562-569.

Feng, P.C. 1956. A preliminary survey of the medicinal plants of British Guiana. West Indian Medical Journal 5:265-270.

Ferreira, J.M., Sousa, D.F., Dantas, M.B., Fonseca, S.G.C., Menezes, D.B., Martins, A.M.C., and M.G.R. De Queiroz. 2012. Effects of Bixa orellana L. seeds on hyperlipidemia. Phytotherapy Research 27:144-147.

Fraser, L. M. 1891. History of Trinidad Volume 1 - 1781-1813. (Authorized Facsimile 1980) Government Printing Office, Port-of-Spain, Trinidad.

Ghosh, R.B. and D. Das. 1999. A Preliminary Census and Systematic Survey of Antidiabetic Plants of Midnapore District, West Bengal, India. Journal of Economic and Taxonomic Botany 23:535-538

Girón, L.M., Freire, V., Alonzo, A. and A. Cáceres. 1991. Ethnobotanical Survey of the Medicinal Flora used by the Caribs of Guatemala. Journal of Ethnopharmacology 34:173187.

Government of the Republic of Trinidad and Tobago (GORTT), Central Statistical Office. 2011. 2011 Population and Housing Census Demographic Report. Ministry of Planning and Sustainable Development, Central Statistical Office, Port of Spain, Trinidad.

GRIN Taxonomy for Plants. 2016. USDA, ARS, National Genetic Resources Program. Germplasm Resources Information Network. National Germplasm Resources Laboratory, Beltsville, Maryland. http://www.ars-grin.gov/ sbmljw/cgibin/paper.pl?language $=$ en $($ September 2015).

Gupta, M. P., Arias, T. D., Correa, M., and S.S. Lamba. 1979. Ethnopharmacognostic Observations on Panamanian Medicinal Plants. Part I. Quarterly Journal of Crude Drug Research 17(3-4):115-130.

Gupta, M.P. (Ed.). 1995. 270 Plantas Medicinales Iberoamericanas, Programa Iberoamericano de Ciencia y Tecnología para el Desarrollo 1st ed. Subprograma de Química Fina Farmacéutica, Santafe de Bogotá, Colombia.

Halberstein, R. A., and A. B. Saunders. 1978. Traditional Medical Practice and Medicinal Plant Usage on a Bahamian Island. Culture, Medicine and Psychiatry 2:177-203.

Heinen, H. D., and A. García-Castro. 2000. The multiethnic network of the lower Orinoco in early colonial times. Ethnohistory 47(3-4):561-579. 
Helmsta“dter A. 2007 Antidiabetic drugs used in Europe prior to the discovery of insulin. Pharmazie 62:717-720.

Hodge, W. H. and D. Taylor. 1957. The Ethnobotany of the Island Caribs of Dominica. Webbia 12:513-644.

Hofman, C. L., Bright, A. J., Boomert, A., and S. Knippenberg. 2007. Island rhythms: the web of social relationships and interaction networks in the Lesser Antillean archipelago between 400 BC and AD 1492. Latin American Antiquity 18(3):243-268.

House, P., Lagos-Witte S. and C.Torres. 1990. Manual Popular de 50 Plantas Medicinales de Honduras. Comité Nacional de Salud de Honduras, Tegucigalpa, Honduras.

International Diabetes Federation. 2013. IDF Diabetes Atlas, 6th ed. International Diabetes Federation, Brussels, Belgium.

International Plant Names Index (IPNI) (2012). Published on the Internet http://www.ipni.org [accessed 1 June 2016].

Irwin, H. S. and R. C. Barneby. 1982. The American Cassiinae. Memoirs of the New York Botanical Garden 35:1-918

Iwu, M. M. 1993. Handbook of African Medicinal Plants. CRC Press, Boca Raton, FL.

Iwu, M. M. 1994. African Medicinal Plants in the Search for New Drugs based on Ethnobotanical Leads. Pages 116-129 in G.T. Prance, D.J. Chadwich and J. Marsh, eds., Ethnobotany and the Search for New Drugs. Wiley \& Sons, Chichester, England.

Jain, S. K., and R.A. de Filipps. 1991. Vol 1 and 2. Medicinal plants of India. Reference Publications, Algonac, MI.

Junsongduang, A., Balslev, H., Inta, A., Jampeetong, A., and P. Wangpakapattanawong. 2014. Karen and Lawa medicinal plant use: Uniformity or ethnic divergence? Journal of Ethnopharmacology 151:517-527.

Kenny, J. S. 2000. Views from the ridge: Exploring the Natural History of Trinidad and Tobago. Prospect Press, Port of Spain, Trinidad.

Kumar, K. and A.K. Goel. 2000. Frequently used Ethno-medicinal Plants of Bihar. Pages 645-649 in J.K. Maheshwari, Ethnobotany and medicinal plants of the Indian subcontinent, Scientific Publishers, Jodhpur, India.

Lachman-White, D. A., Adams, C. D., and U.O.D. Trotz. 1992. A Guide to the Medicinal Plants of Coastal Guyana (Vol. 8). Commonwealth Science Council, Commonwealth Secretariat, London. 
Laguerre, M.S. 1987. Afro-Caribbean folk medicine. Bergin-Garvey, South Hadley, MA.

Lalueza-Fox, C., Calderon, F., Calafell, F., Morera, B., and J. Bertranpetit. 2001. MtDNA from extinct Tainos and the peopling of the Caribbean. Annals of Human Genetics 65(2): $137-151$.

Lans, C. 2001. Creole remedies: case studies of ethnoveterinary medicine in Trinidad and Tobago. Wageningen Universiteit, Ph.D. Thesis Publication.

Lans, C.A. 2006 Ethnomedicines used in Trinidad and Tobago for urinary problems and diabetes mellitus. Journal of Ethnobiology and Ethnomedicine 2:45

Lantum, D. N. 1980. The Knowledge of Medicinal Plants in Africa Today. Journal of Ethnopharmacology 2:9-17.

Leon, R. 1959. Phytothérapie haïtienne, nos simples. Imprimerie de l'État, PuertoPrincipis, Haiti

Leonti, M. 2011. The future is written: Impact of scripts on the cognition, selection, knowledge and transmission of medicinal plant use and its implications for Ethnobotany and Ethnopharmacology. Journal of Ethnopharmacology 134:542-555.

Longuefosse, J. and E. Nossin. 1996. Medical ethnobotany survey in Martinique. Journal of Ethnopharmacology 53:117-142.

Mahabir D., and M.C. Gulliford. 1997. Use of medicinal plants for diabetes in Trinidad and Tobago. Revista panamericana de salud publica $=$ Pan American Journal of Public Health 1:174-179

Mahabir N.K. 1991. Medicinal and edible plants used by East Indians of Trinidad and Tobago. Chakra Publishing House, Trinidad W.I.

Major, R.H. II. 1932 ( $1^{\text {st }}$ ed., $5^{\text {th }}$ printing). Classic descriptions of disease with biographical sketches of the authors. Charles C. Thomas Publishers Springfield, IL

Mans, D.R.A. 2012. Efficacy of Surinamese plants in the therapy of diabetes mellitus analysis of literature. Academic Journal of Suriname 3:276-283

McClure, S. A. 1982. Parallel usage of Medicinal Plants by Africans and their Caribbean descendants. Economic Botany 36:291-301.

Morrison, E.Y.S.A. and M.E. West. 1982. A preliminary study of the effects of some West Indian medicinal plants on blood sugar levels in the dog. West Indian Medical Journal 31(4):194-197.

Morton, J.F. 1968. A survey of medicinal plants of Curacao. Economic Botany 22:87102. 
Morton, J. F. 1975. Current Folk Remedies of Northern Venezuela. Quarterly Journal of Crude Drug Research 13:97-121.

Morton, J.F. 1977. Medicinal and other Plants used by People on North Caicos (Turks and Caicos Islands, W. I.). Quarterly Journal of Crude Drug Research 15:1-24.

Murray, J. A. 1989. The Plants and Drugs of Sindh. Indus Publication, Karachi, Pakistan.

Muthiah, S. 1987. A Social and Economic Atlas of India. Delhi: Oxford University Press.

Núñez Meléndez, E. 1978. Plantas medicinales de Costa Rica y su Folclore. Editorial Universidad de Costa Rica, San Jose, Costa Rica.

Núñez Meléndez, E. 1982. Plantas medicinales de Puerto Rico: folklore y fundamentos científicos. Editorial de la Unversidad de Puerto Rico, Río Piedras, Puerto Rico.

Oliver-Bever, B.E.P. 1986. Medicinal Plants in Tropical West Africa, Cambridge University Press, Cambridge, UK

Ottley, C. R. 1973. The story of Tobago, Robinson Crusoe's Island in the Caribbean. Longman Caribbean, Trinidad.

Panda, P.C. and P. Das. 2000. Medicinal Plant-lore of the Tribals of Baliguda subdivision, Phulbani District, Orissa. Pages 515-521 in J.K. Maheshwari, ed., Ethnobotany and medicinal plants of Indian subcontinent. Scientific Publishers, Jodhpur, India.

Paul, A. and P.A. Cox. 1995. An Ethnobotanical survey of the uses for Citrus aurantium (Rutaceae) in Haiti. Economic Botany 49:249-256.

Paul, S.R. 1977 Medicinal Plants of Netarhat, Bihar (India). Quarterly Journal of Crude Drug Research 15:79-97

Payne-Jackson, A., and M. C. Alleyne. 2004. Jamaican Folk Medicine: A Source of Healing. University of the West Indies Press, Kingston, Jamaica.

Pieroni, A. and I. Vandebroek (Eds.). 2007. Travelling Cultures and Plants: The Ethnobiology and Ethnopharmacy of Migrations, vol. 7: Studies in Environmental Anthropology and Ethnobiology, Berghahn Books, New York, NY

Quinlan, M.B. 2004. From the Bush: The Front Line of Health Care in a Caribbean Village. Wadsworth/Thomson Learning, Belmont, CA.

Rana, T.S., Singh, K.K. and R.R. Rao. 1999. Studies on indigenous herbal remedies for Diabetes Mellitus in India. Journal of Economic and Taxonomic Botany 23:115-120. 
Reyes-García, V., Broesch, J., Calvet-Mir, L., Fuentes-Peláez, N., McDade, T.W., Parsa, S., Tanner, S., Huanca, T., Leonard, W.R. and M.R. Martínez-Rodríguez. 2009. Cultural transmission of ethnobotanical knowledge and skills: an empirical analysis from an Amerindian society. Evolution and Human Behavior 30:274-285.

Rodríguez Martínez, N. 1999. Plantas medicinales: Guía fitoterapeútica. Santo Domingo: Ediciones Librería La Trinitaria

Roig, J.T. 1945. Plantas medicinales: aromáticas o venenosas de Cuba. Ministerio de Agricultura, servicio de Publicidad y Divulgación

Roopnarine, L. 2007. Indo-Caribbean indenture: Resistance and accommodation, 18381920. Kingston, Jamaica: University of the West Indies Press.

Roth, I. and H. Lindorf. 2002. South American medicinal plants: Botany, remedial properties, and general use. Berlin: Springer-Verlag.

Santiago-Valentin, E. and R.G.Olmstead. 2004. Historical biogeography of Caribbean plants: Introduction to current knowledge and possibilities from a phylogenetic perspective. Taxon 53:299-319.

Saxena, H. O., Brahman, M. and P. K. Dutta. 1981. Ethnobotanical Studies in Orissa. Pages 232-244 in S.K. Jain, ed., Glimpses of Indian Ethnobotany. Oxford and IBH Publishing Co., New Delhi, India.

Schadewaldt, H. 1989. The history of diabetes mellitus. Pages 43-100 in D. von Engelhardt, ed., Diabetes, its medical and cultural history. Springer-Verlag, Berlin.

Seaforth C.E., Adams C.D., and Y. Sylvester. 1986. A guide to the medicinal plants of Trinidad \& Tobago. Caribbean Industrial Research Institute (CARIRI), Tunapuna, Trinidad and Tobago, W.I.

Seaforth C.E., Ballah S., Rollocks S., S. Craig-James. 1998. Medicinal Plants used in Tobago. Fitoterapia 69:523-527

Shah, N.C. 1982. Herbal Folk Medicines in Northern India. Journal of Ethnopharmacology 6:293-301

Simpson, G.E. 1962. Folk Medicine in Trinidad. Journal of American Folklore 78:326340

Sivarajan, V. V., and I. Balachandran. 1994. Ayurvedic Drugs and their Plant Sources. Oxford and IBH Publishing, New Delhi, India.

Stannard, J. 1982. Medicinal Plants and Folk Remedis in Pliny, "Historia Naturalis." History and Philosophy of the Life Sciences 4:3-23. 
Stevens, P.F. 2001 onward. Angiosperm Phylogeny Website, Version 12, July 2012. [more or less continuously updated]. http://www.mobot.org/MOBOT/research/APweb/ (September 2015).

The Plant List. 2013. The Plant List: A working list of all plant species, Version 1.1. http://www.theplantlist.org/(September 2015)

Touwaide, A. and E. Appetiti. 2013. Knowledge of Eastern materia medica (Indian and Chinese) in pre-modern Mediterranean medical traditions: A study in comparative historical ethnopharmacology. Journal of Ethnopharmacology 148(2):361-378.

Tropicos. 2016. Tropicos.org. Missouri Botanical Garden. http://www.tropicos.org (September 2015)

van Andel, T. R. 2000. Non-timber forest products of the North-West District of Guyana. Tropenbos-Guyana Series; 8a, 8b.

van Andel, T.R., van't Klooster, C.I.E.A., Quiroz, D., Towns, A.M., Ruysschaert, S., and M. van den Berg. 2014. Local plant names reveal that enslaved Africans recognized substantial parts of the New World flora. Proceedings of the National Academy of Sciences 111(50):E5346-5353.

Voeks, R.A. 1990. Sacred Leaves of Brazilian Candomble. Geographical Review 80(2):118-131

Voeks, R. A. 2004. Disturbance Pharmacopoeias: Medicine and Myth from the Humid Tropics. Annals of the Association of American Geographers 94:868-888.

Voigts, L.E. 1979. Anglo-Saxon Plant Remedies and the Anglo-Saxons. ISIS 70:250268.

von Engelhardt, D. (Ed.). 1989. Diabetes: Its medical and cultural history. SpringerVerlag, Berlin.

Voyages Database. 2016. Voyages: The Trans-Atlantic Slave Trade Database. http://www.slavevoyages.org (accessed August 1, 2014).

Weller, J.A. 1968. The East Indian Indenture in Trinidad. Institute of Caribbean Studies, University of Puerto Rico, Rio Piedras, P.R.

Wilder, R.M. 1989. Karl Petren: A Leader in Pre-Insulin Dietary Therapy of Diabetes. Pages 405-407 in D. von Engelhardt, ed., Diabetes, its medical and cultural history. Springer-Verlag, Berlin, Germany.

Williams, R.O. and R.O. Williams, Jr. 1951. Useful and Ornamental Plants of Trinidad and Tobago, 4th edition. Guardian Commercial Printery. Port-of-Spain, Trinidad. 
Wong, W. 1976. Some Folk Medicinal Plants from Trinidad. Journal of Economic Botany 30:103-142

World Health Organization (WHO). 2002. WHO Traditional Medicine Strategy 20022005 World Health Organization, Geneva, Switzerland.

World Health Organization (WHO). 2013. WHO Model list of Essential Medicines (18 ${ }^{\text {th }}$ list). World Health Organization, Geneva, Switzerland. http://www.who.int /medicines/publications/essentialmedicines/18th_EML_Final_web_8Jul13.pdf]

Xie, J.T., Mchendale, S., and C.S. Yuan. 2005. Ginseng and diabetes. The American Journal of Chinese Medicine 33:397-404. 


\title{
CHAPTER III
}

\section{THE FOLK DISEASE CONCEPTION OF DIABETES MELLITUS AND ITS REMEDIES IN TRINIDAD AND TOBAGO}

\begin{abstract}
With the increasing prevalence of diabetes mellitus (DM) in developing countries there appear to be more ethnobotanical studies on the use of botanical remedies to treat DM symptoms. The strategies used to identify those plant remedies may involve application of folk classificatory systems that have been passed on through various cultures for centuries. Greek humoral theory of the hot-cold balance is one example of a classificatory system that is still in use.

To determine the folk disease concepts of DM that were predominantly in use for Trinidad and Tobago, a developing country with $14 \%$ prevalence of DM, I used social network analysis tools. The measure of degree centrality indicated that of three prevailing disease concepts, the local DM remedies were most closely aligned to the hotcold disease concept. Yet the shared use of DM remedies to treat symptoms of urinary complaints and high blood pressure suggests that familiar remedies are being adopted based on similarity of disease symptoms. Literature reviews and field surveys indicated that the most commonly cited antidiabetic species were Paleotropical natives, including Momordica charantia and Catharanthus roseus. Furthermore, $80 \%$ of the DM remedies were previously published local remedies, though 50\% had not been recorded as antidiabetics before 2000. I discussed possible biomedical mechanisms by which the
\end{abstract}


cooling, cleansing and bitter remedies of T\&T may address DM.. Nevertheless, as the phytochemicals that lend cooling, cleansing and bitter properties to these plants may in some instances be cytotoxic, the general application of these disease concepts to selecting remedies among unfamiliar plants is not recommended.

\section{INTRODUCTION}

The prevalence of diabetes mellitus (DM) has increased markedly over the last two decades and it is expected to continue to rise. The highest per capita increases are projected to occur among low and middle-income countries. In many of these countries, access to modern healthcare is limited and 60 to $90 \%$ of the populace still relies on traditional medical systems of care (WHO 2002; IDF 2015).

Although diabetes has been recognized for centuries (having first been explicitly

described by the $2^{\text {nd }}$ century Greek physician Aretaeus), it was said to only occur infrequently. The Greek physician Galen (129-199 AD) is said to have treated only 2 cases of diabetes throughout his career (Major 1932; Zajac et al. 2010).

As the incidence of diabetes has steadily increased, greater proportions of healthcare budgets are applied to its treatment in developed countries (IDF 2015). But there appears to be an alternative strategy in developing countries with limited resources: the application of local botanical remedies to treat DM symptoms (Andrade-Cetto 2010).

There is evidence of this increased utilization in the ethnobotanical literature. Whereas only ten studies on diabetes pharmacopoeias were published from 1980 to 2000, over the last 15 years, the number of such ethnobotanical studies increased six-fold 
(Appendix Sheet 1). Many of the recent studies occurred in the same areas where DM incidence is projected to have the highest increases by 2030 (Whiting et al. 2011).

The questions of interest to my research are whether current diabetes remedies are based on previously known plant species, what system is used to select the plants used and whether this system has any parallels in contemporary biomedicine.

To address these queries, I chose to look at the developing country of Trinidad and Tobago $(\mathrm{T} \& \mathrm{~T})$. In the Caribbean region where $\mathrm{T} \& \mathrm{~T}$ is located, the percentage of deaths from diabetes increased from $6 \%$ in 1985 to $10 \%$ in 2000 (CAREC 2005). In T\&T, diabetes was the third leading cause of mortality in 2008 (GOTT 2008) and its prevalence in 2015 was estimated at $14.5 \%$ (IDF 2015). There is a history of plant use for treating DM symptoms in T\&T and, as shown in the previous chapter, almost 50 plant species were recorded as antidiabetics from ethnobotanical studies conducted prior to 2000. Given these factors of high DM prevalence and prior knowledge of botanical DM remedies, I posit that a comparative analysis of the current and previous remedies (pre and post-2000) can provide insight into the types of plants used and highlight any patterns in plant selection that point to the use of folk classification strategies in T\&T. Berlin (1992) has shown that folk botanical classifications are robust, such that their use within a cultural group is clearly defined. In some studies, folk botanical classification has been observed as cognitive constructs used to differentiate species (e.g., ethnolinguistic features), while in others, humoral concepts of balance (e.g., hot/cold) were used to differentiate ailments and from thence their associated plant species. A third approach to botanical classification, somewhat similar to humoral concepts, is based on sensory constructs (e.g., organoleptic features), where organoleptic characteristics are 
often viewed as being opposite to the disease state that needs to be balanced (Ankli et al. 1999; Berlin 1999; Heinrich 1998; Leonti et al. 2002; Pieroni et al. 2002; Pieroni and Torry 2007). This study will look at humoral concepts and sensory-based constructs present in the folk disease concepts of T\&T.

\section{Background: Folk Disease Concepts}

In many traditional cultures, concepts about disease origins can be divided into two-groups - personalistic (a.k.a. supernatural) and naturalistic. In some cases, illnesses are viewed on a continuum from the supernatural to the natural (Foster 1976; Murdock 1980). While supernatural powers (e.g., gods, spirits, ancestors, etc.) are viewed as causing personalistic illnesses, illnesses perceived to be of natural origin, are often thought to be caused by an imbalance between two or more opposing natural elements, such as the yin and yang of Chinese traditional medicine (Harris 1991) or the vata, pitta and kapha of Indian Ayurvedic medicine (Sivarajan and Balachandran 1994).

For ancient Greeks, maintaining health involved maintaining the balance of four bodily fluids or humors: blood, yellow bile, black bile and phlegm. Hippocrates and his contemporaries believed that each fluid was comprised of two of the four primary qualities of matter: dry, wet, cold and heat (Fig 1). Later, Galen cemented these ideas in medical thought through his extensive writings and, like other classicists, linked them to the four natural elements (i.e., air, fire, earth, and water) (Nutton 1995).

The humoral medicine theory of the Greeks was adopted by many of the European cultures that colonized the New World. Some researchers suggest that it is the foundation for the prevalent hot/cold disease concepts in the New World (Foster 1987). 
Yet, other researchers posit that similar ideas may have developed independently (Ortiz de Montellano 1986). Etkin (1988) indicates that the idea of health as the restoration of balance is a pervasive concept in many cultural models of disease.

Despite the seemingly primitive nature of such ideas, modern western medical systems also employ the idea of restoring balance or, more specifically, using opposite or "unlike" treatments to address disease symptoms--hence the term "allopathic" medicine. This is in contrast to the term homeopathic medicine that is based on the idea "let like cure like" or the law of similars first attributed to Hippocrates (Junod 2000).

Furthermore, the persistence and pervasiveness of the foundational idea of curing by restoring balance, suggests that it provides some form of systematization, perhaps as a memory tool (similar to the function of Doctrine of Signatures—See Bennett 2007) or as a folk taxonomic tool that allows its users to comprehend unfamiliar plants and diseases.

If migrants arrived in the New World with an extant disease classification system, one might predict that they would assign unfamiliar diseases into known categories, based on similar disease symptoms or in relation to the affected body system. One might also expect that the basis for selecting plant remedies to treat such unfamiliar diseases would be migrants' history of using those plants (or their congenerics) to treat any ailments considered to be similar in nature. In the case of diabetes, the recent increase in prevalence in the developing world and the concomitant rise in the number of ethnobotanical studies of antidiabetic remedies may therefore arise from the application of folk disease concepts or a "folk empirical practice" (Palmer 2004).

The nature of DM is such that a biomedical understanding of its etiology and treatment was largely a mystery even as recently as the late $19^{\text {th }}$ and early $20^{\text {th }}$ century. 
As the primary disease symptoms are excessive thirst and urination, it is not difficult to see how DM was considered to be a malfunction in the urinary system for over 1500 years (Eknoyan and Nagy 2005). Without the in-depth knowledge of the regulatory hormones involved in glucose metabolism, there was no basis for associating DM with processes of the digestive and endocrine systems.

Therefore, in those societies or cultural groups where biomedical disease concepts have not become fully entrenched, culturally-based or folk disease concepts (or some hybrid form of folk and biomedical concepts) tend to be applied, especially for a disease like DM. One example of cultural DM disease concepts is the idea among some Latin Americans that diabetes is brought on when an individual has an experience that results in strong emotions such as fear or grief or anxiety (Santos et al. 2009; Weller et al. 1999). Could it be that this is an extension of the idea of the loss of bladder control that occurs when a person is afraid? In another scenario, some African-Americans attribute diabetes to the excessive consumption of sweets in childhood or over an individual's lifetime (Schoenberg et al. 1998). Here, they may have conjured up a causal link using the similar biomedical concepts of hyperglycemia and hypercholesterolemia, with the notion that sugar, like bad cholesterol, had accumulated over time in the individual's blood.

For Trinidad and Tobago (T\&T), there are at least three disease concepts associated with DM. The first of these, "heat versus cold", is a humoral/balance concept and has been referenced in previous studies (Lans 2001; Wong 1976), where it is suggested to be the overarching disease concept applied to many other ailments in T\&T. A second balance concept of "clean blood" vs "dirty blood" is also commonly applied to other illnesses. The third concept of "sweet blood" versus "bitter blood" appears to be 
more narrowly related to DM, though the idea has been linked to other scenarios, such as explaining the reason why one person may be a target of mosquitos (sweet blood) and another is not. This third concept melds elements of balance concepts and sensory-based constructs.

In T\&T, the hot versus cold balance may be traced back to European medical thought as well as traditional Chinese and Ayurvedic medicine which also reference the idea of plant remedies possessing heating or cooling properties (Harris 1991; Sivarajan and Balachandran 1994). A similar hot versus cold system is said to have been found among the Aztecs and as such, it may have possibly existed in some form among the indigenous groups that populated Trinidad and Tobago before European arrival (Ortiz de Montellano 1986 ).

The clean versus dirty blood concept may possibly be connected to the historic practice in many cultural traditions (including Western herbal medicine) of using purgatives and emetics for their immediate cathartic effect (Porter 1995). Among many traditional practices in Africa, the idea of "washing away the sickness" (Harley 1970) is common and is achieved with the use of baths, fomentations, and enemas. Such ideas are also apparent in the African diaspora. Some African Americans consider the periodic use of laxatives as a practice needed to cleanse the blood (Laguerre 1987). Within the AfroCaribbean context, such as in Haiti or Jamaica, "bad blood" or "dirty blood" has a specific connotation referring to the presence of venereal disease (Freeman 1998; PayneJackson \& Alleyne 2004). Nevertheless, in Cuba, venereal disease is viewed as only one of many types of impurities in the blood that can be cleansed using plant remedies, though not typically laxatives (Volpato and Godinez 2004). 
The basis for the sweet versus bitter blood concept appears to be the hybridization of old and new ideas. That the bitter-tasting properties of medicine were expected to be the norm is readily seen in the idiomatic expression "a taste of one's own medicine" and the adage that "a spoonful of sugar makes the medicine go down." Many studies among indigenous groups mention the apparent value associated between a medicine's bitterness or astringency and its potency or efficacy (Etkin et al. 1996; Harley 1970; Shepard, 2004). One specific example related to diabetes is the traditional use of the heartwood of Pterocarpus marsupium Roxb. in India, on account of its bitter, astringent properties (Bhargava 1946). In Guyana, persons who contracted malaria often or who had diabetes were said to have "sweet blood" (van Andel 2000). Since the biomedical understanding of diabetes includes the presence of excess sugar in the blood, the idea of applying traditional bitter medicines to counteract the blood's sweetness seems to be a simple, logical step (Andrade-Cetto 2010).

By elucidating folk models of a disease, alternative perspectives on the pathology of that disease, or its particular epidemiological features within that specific cultural group may be deduced. Furthermore, the organoleptic plant properties that guide selection may highlight biochemical properties of importance to comprehend the way that a plant remedy functions. Lastly, for health providers, the awareness of folk disease models (and associated treatments) may open the door to more effective patient care where potential risks and benefits of traditional remedies can be addressed. 
The objectives for this study were:

1. To identify the plant species historically and recently indicated as antidiabetic remedies in Trinidad and Tobago (T\&T) and determine the most popular (commonly cited) species

2. To ascertain whether a folk classification system or folk disease concept influenced the selection of the antidiabetic remedies of T\&T

3. To determine whether parallels exist between T\&T folk disease concepts and established biomedical mechanisms of diabetes pathology

\section{METHODS}

\section{Literature Survey}

To identify those antidiabetic remedies that were historically used in Trinidad and Tobago, I surveyed the literature for ethnobotanical studies conducted prior to 2000 . Further details of this process were outlined in the previous chapter.

\section{Field Surveys}

I visited rural, urban, and suburban areas across Trinidad and Tobago in 2009, 2011 and 2012 to interview individuals about local botanical remedies in general and to find out particularly about remedies used to treat symptoms of diabetes. Individuals were targeted using snowball sampling techniques. This method involved contacting a readily accessible group of individuals and then building a network of participants from initial contacts (Bernard 2002). Some of these initial contacts were previously known, while 
others were made through schools and community-based organizations. I asked all of these contacts to identify individuals within their families or communities who were familiar with T\&T plant remedies. I then interviewed these persons using a semistructured survey instrument. For convenience, these individuals will be referred to as community participants.

In 2011 and 2012, in-person interviews were also conducted with individuals in Trinidad and Tobago who supply herbs or herbal supplements to the public. Most were identified through listings in the telephone directory; others were found through snowball sampling techniques. These interviews were also semi-structured and were audio recorded where permitted by the participants. For convenience, this second group of individuals will be subsequently referred to as herbalists.

In line with Institutional Review Board (IRB) procedures (IRB \#080109-00) of Florida International University, students and their parents first provided written consent, while all other adults provided verbal consent prior to the interview. Permission for research in schools was provided by the Ministry of Education of Trinidad and Tobago, while permission for the research among the herbalists was granted by the Ethics Committee of the Ministry of Health of the Government of Trinidad and Tobago. Four undergraduate students from the University of the Southern Caribbean, who had humansubject research training, assisted with the herbalist interviews.

I deposited voucher specimens of the plant material collected from community and herbalist participants in Trinidad (TRIN) and in the US (FTG). However, fewer vouchers were available from herbalists, since most of the products they supplied were pre-packaged, processed or prepared formulations. Whenever a plant of interest was not 
available on site, and the plant was not commonly known, participants were asked either to provide a specimen on a subsequent occasion or to indicate where one could be obtained. In the absence of plant material, the supplied common name was used to determine binomials.

\section{Antidiabetic Remedies}

From each group of field interviews (community and herbalists), a list of all of the plants cited as antidiabetics was prepared. Lists were also compiled of the published antidiabetic remedies of Trinidad and Tobago separated as pre or post 2000 studies. All lists included scientific names, family names, and place of origin or distribution, as well as the number of times each plant had been cited/mentioned. For unvouchered plants, the Kew Medicinal Plant Names Service (2015) website was used to search for binomials based on common names. Family names follow Stevens (2001) and The Plant List (2013). Information on plants' native range or distribution was derived from USDAGRIN Taxonomy for Plants (2016) and Tropicos (2016).

Comparisons were made between lists of historical and current remedies to determine similarities or differences in the families, genera, and species listed, the representation of Neotropical and Paleotropical plants, the proportions of food vs nonfood plants, and the most popular (i.e.,frequently cited remedies). These comparisons were done to elucidate any evidence of a common folk biological classification system and to determine the extent to which historically used plants continued to be used. 
Folk Disease Concepts in Field and Literature Analysis

Since the hot/cold disease concept has been broadly applied in T\&T folk remedies (Aho and Minnott 1977; Lans 2001; Wong 1976), I anticipated that the current putative antidiabetic remedies might have been selected from previously known remedies in line with that folk model. As such, literature sources and participants' field responses were scoured to find any instances where the recorded antidiabetic remedies were otherwise cited for conditions or characteristics associated with the hot/cold folk model. I simultaneously searched for antidiabetic species that literature reports or participants' surveys identified with the bitter/sweet blood and dirty/clean blood disease concept terms. Lastly, as a means of corroborating the idea that a distinct classification process was being used, I also searched for evidence that antidiabetic remedies were less likely to be associated with contrasting disease models. The search terms and folk disease categories are further detailed below.

Antidiabetic plants that were cited to treat fever, heat or heat rash or any plants described as being used for cooling were assigned to the cold category of the hot versus cold folk paradigm. Plants described as blood cleansers, cleansing agents or purgatives were placed in the dirty/clean blood group. The bitter/sweet blood category was comprised of plants described as bitter-tasting or said to be used to make the blood bitter. For the contrasting disease concepts, there were fewer search terms, as neither dirty blood nor sweet blood are generally considered to be desirable in a healthy person. Therefore, only the search terms that applied to the contrasting side of the hot versus cold concept were included. Quinlan (2004) was particularly useful for corroborating the hot/cold disease concept terms and associated conditions. Thus, any plants that were described as 
having a heating or warming effect were considered opposite to the prevailing DM concept of healing through cooling the system. Also, as per Quinlan (2004), plants were assigned in the opposite group if they were indicated for use in treating cold illnesses, such as coughs, colds or other respiratory conditions, such as asthma or bronchitis.

\section{Social Network Analysis}

I tallied the number of times each antidiabetic plant was cited for each of the conditions/characteristics described, as well as the number of different plants that were cited in relation to each disease concept and formulated these results into valued matrices. The data was divided into two groups: data drawn from the pre-2000 studies was tallied as one group, while data drawn from post-2000 studies and the current field survey results were tallied as another group. Matrices were converted to a binary format and degree centrality values were calculated using the UCINET ${ }^{\circledR}$ social network analysis software. Graphs of these matrices were prepared using the NetDraw ${ }^{\circledR}$ feature of the UCINET® software to show the extent of connectivity between the plants and the different disease concepts (Borgatti et al. 2002).

Social network analysis (SNA) has been used to show how information flows among individuals within a network (Borgatti 2005). In a previous chapter, I used SNA to look for patterns of knowledge transmission among islands/countries in the Caribbean Basin, by looking at commonly shared genera as a proxy for historically shared knowledge.

For the current analysis, I focused on the pervasiveness of a disease concept among the individuals in a society. In this case, the particular categories of ailments for 
which a plant species was cited are being used as a proxy for the individuals' beliefs or ideas about the nature of the plant/disease. The measure of centrality used here-the degree centrality—is indicative of the number of ties connected to each node (Borgatti 2005), with the primary nodes of interest being the disease concepts. As such, it is expected that those disease concepts having the greatest number of plant remedies assigned to them will have the highest measures of centrality. In this way, the predominant disease concept associated with diabetes in T\&T can be inferred.

The social network analysis was also used to indicate those plants that are aligned to all three disease concepts, both historically and currently, which may provide insight into the plants that are most popular and, perhaps, most efficacious in addressing DM symptoms.

\section{RESULTS}

\section{Field Surveys}

The community participants in the field interviews comprised 80 individuals; while the herbalist interviews included 32 participants. While the proportion of females was greater among the community participants, the reverse was true for the herbalists. There was a greater proportion of younger participants with tertiary level education among the herbalists. (Detailed demographic information on all participants is included in Appendix Sheet 2.) 
Antidiabetic Remedies

Forty-eight plant species were cited as antidiabetic remedies in the historical studies (pre-2000) (see Appendix Sheet 3A), while 30 species were cited in the recent (post-2000) literature (Appendix Sheet 3B). Community participants cited a total of 46 antidiabetic species (Appendix Sheet 3C), while the 32 herbalists cited 51 plants (Appendix Sheet 3D). A compilation of these lists resulted in a total of 114 putative antidiabetic remedies, and included native, naturalized, and several imported species. Thus, a majority $(58 \%)$ of the local antidiabetic remedies are new citations since 2000.

Of the 48 plants cited as antidiabetics in the pre-2000 literature, 22 species were cited by the community participants and 14 were cited by herbalists. Thus although a slightly greater proportion (52\%) of remedies cited by community participants were new, almost three-quarters (73\%) of herbalists remedies were new citations. Furthermore, $62 \%$ of the new remedies cited by the mainly-urban herbalists were non-native, imported remedies, not known to be cultivated on the islands, including food and medicinal plants. Only two suburban community participants cited plant species (Cnidoscolus aconitifolius (Mill.) I. M. Johnst. and Vernonia amygdalina Delile) that they had imported and planted. One of these species (V. amygdalina) was also cited among the rural populace sampled in the recent literature, as an antidiabetic remedy (Clement et al. 2015).

By excluding the imported, non-food plant products that had been cited as DM remedies, the total number of antidiabetic species was reduced to 99 (Table 1), which is approximately equal to one-third of the $300^{+}$published medicinal plants of Trinidad and Tobago. This total includes 49 Neotropical species, 30 Paleotropical species, as well as 3 Pantropical species. The other species were extratropical. The families with the most 
species cited were Fabaceae (9) and Asteraceae (8), followed by Rubiaceae, Cucurbitaceae, and Poaceae with four each. There were $40 \mathrm{food} / \mathrm{spice}$ plant species.

From the post-2000 literature and field surveys, the most popular (commonly cited) antidiabetic species were identified (Table 2). A total of 26 plants were cited by at least three participants. Of these, the three most popular were Momordica charantia L., Catharanthus roseus (L.) G. Don and Azadirachta indica A. Juss, which are all Paleotropical natives that were listed as antidiabetics in the pre-2000 literature. Almost half (12 of 26) of the popular remedies had not been cited as antidiabetics before 2000.

Folk Disease Concepts in Field and Literature Analysis

The five ethnobotanical studies that were used for the pre-2000 literature review described broad medicinal plant uses in Trinidad and Tobago and were conducted between 1966 and 1995 (Wong 1976, Seaforth et al. 1983, Mahabir 1991, Seaforth et al. 1998, Lans 2001). The tallies from this literature review resulted in a total of 29 antidiabetic plants that were mentioned by two or more sources as being affiliated with at least one of the three disease concept categories (Figure 2). Only two plants, Azadirachta indica and Momordica charantia were affiliated with all three disease concepts

When the results of the post 2000 literature and field surveys were scoured for disease concept affinities, 20 antidiabetic remedies were indicated (by $3^{+}$citations) to be affiliated with at least one of the three disease concepts (Figure 3). Three plants, two Paleotropicals, Aloe vera and Momordica charantia, and one Neotropical, Neurolaena lobata, were affiliated with all three disease concepts. 
A comparison of the list of the popular antidiabetics (Table 2) with the plants aligned to the three-disease concepts, showed fairly similar numbers of popular antidiabetics in the pre-and post-2000 groups (Figures 2 and 3). What differed was the measure of alignment among the disease concepts.

Eight popular plants co-occur in the pre-2000 three-disease concept group. Two (Momordica charantia and Azadirachta indica) are aligned to all three disease concepts, three (Aristolochia rugosa, Neurolaena lobata, and Stachytarpheta jamaicensis) are aligned to two disease concepts and three (Bontia daphnoides, Mimosa pudica, and Spermacoce verticillata) are aligned to one disease concept

Five of the commonly cited plants are aligned to at least one disease concept in the post-2000 three-disease concept group. Two species (Momordica charantia and Neurolaena lobata) were aligned to all three disease concepts, two (Bontia daphnoides and Stachytarpheta jamaicensis) were aligned to two disease concepts, and one (Bryophyllum pinnatum) was aligned to one disease concept.

\section{Emerging Disease Concepts}

In the process of searching the literature and participants' field survey responses for connections among the antidiabetic remedies and the disease concepts, there emerged two other ailment categories/conditions that seemed to be associated with the antidiabetic remedies: hypertension/high blood pressure and urinary problems. From the post-2000 literature and field data, participants mentioned 16 of the plants known as antidiabetics to be used to treat "pressure" or when "pressure [is] high." Others mentioned nine antidiabetic plants for urinary complaints described in terms such as "stones", "stoppage 
of water", and "pain to go to the bathroom." Similar associations were found in the pre2000 literature, to the extent that 25 antidiabetic plants were also cited for hypertension/high blood pressure while for urinary complaints, 23 were cited.

Many of the antidiabetic plants that were cited for high blood pressure and urinary complaints were also among those that had been cited for the three prevailing diabetes disease concepts (hot/cold; clean/dirty; bitter/sweet). Within the pre-2000 literature, a total of 49 plants were indicated to be aligned with at least one of these five disease concepts/ ailment categories, with one plant, Azadirachta indica being aligned with all five categories (Figure 4). As for the post 2000 findings, a total of 38 plants were cited in relation to at least one of the five categories/ concepts. No plants were aligned with all five categories, but Bontia daphnoides and Momordica charantia were aligned to four categories (Figure 5). The graphical representation (Figures $4 \& 5$ ) of the levels of connectedness among the plants and the five disease categories/concepts indicates that whereas 15 plants were linked to at least three of the five concepts in the pre-2000 data, only 6 plants in the post-2000 data showed similar connectedness.

Seventeen of the popular antidiabetic plants (Table 2) were aligned to at least one disease concept in the pre-2000 five-disease category group. Fourteen of these pre-2000 plants were aligned to two or more disease concepts. Meanwhile, fifteen of the popular plants were aligned to at least one disease concept in the post-2000 five-disease category group. Of these, six were aligned to at least two disease concepts. In all, 14 popular plants occurred in both the pre- and post-2000 groups. 


\section{Opposite Disease Concept}

The antidiabetic plants most commonly referenced in the pre-2000 literature for coughs and colds were: Hibiscus rosa-sinensis; Abrus precatorius, Eryngium foetidum, Chromolaena odorata, and Cordia curassavica. The most commonly cited antidiabetic plant remedies for coughs and colds in the post-2000 literature and field surveys were Leonotis nepetifolia (126), Neurolaena lobata (64), Cecropia peltata (32), C. odorata (28), and C. curassavica (24). The frequent number of participant citations in the post2000 data for the top five plants used for coughs and colds attests to the continued importance of traditional remedies for treating common infectious diseases.

From the pre-2000 data compilation, there were 11 antidiabetic remedies aligned to the two contrasting aspects of the hot-cold disease paradigm (Figure 6). In this group, 10 plants had been cited historically as DM remedies: three Paleotropical species and seven Neotropicals. Bontia daphnoides, Neurolaena lobata, and Stachytarpheta jamaicensis are the only three species that also occur in the list of T\&T popular antidiabetics (Table 2). Seven of these 11 species have notably pungent odors/taste; two are commonly cultivated for food flavoring, but four are considered as weeds.

From the post-2000 literature and field surveys, a similar picture emerges (Figure 7). Nine antidiabetic plants are cited $3^{+}$times for use in treating both contrasting categories of hot-cold ailments. Seven plants were among the historically cited DM remedies, and of those, one is Paleo-temperate, while there are three each of Paleotropical and Neotropical origin. Only Momordica charantia and Neurolaena lobata also occur within the list of popular T\&T antidiabetics (Table 2). They along with Aloe vera and 
Leonotis nepetifolia indicate an increase in the proportion of bitter plants used for colds and fevers. Meanwhile, three odoriferous spice/flavorings are also included in this group.

Social Network Analysis

The network analysis diagrams (Figures 2 and 4) for the data from the pre-2000 literature shows a greater level of connectivity from the plants to the hot-cold disease concept. For the 3-disease concept analysis, calculations of the degree centrality showed the highest value for the hot/cold disease concept (1.000), which indicates that all 29 plants were aligned with it. The centrality values for the clean/dirty disease concept (0.241) and the bitter/sweet disease concept (0.276) were not markedly different from each other. For the 5-disease concept analysis, degree centrality was again highest for the hot/cold concept (0.837) but high blood pressure (0.510) and urinary ailments (0.469) were notably higher than the clean/dirty (0.143) and bitter/sweet (0.163) disease concepts. The plant, Azadirachta indica had a degree centrality of (1.000) for both 3- and 5-disease concept analyses of pre-2000 data, while Momordica charantia had a degree centrality of 1.000 and 0.800 for the 3-disease and 5-disease concept graphs, respectively. From the SNA analysis of the post-2000 literature and field data (Figures 3 and 5) the hot-cold disease concept is still the most entrenched. In the 3-disease concept analyses, although the degree centrality for the clean/dirty concept was distinctly higher (0.550) than that for the bitter/sweet concept (0.200), the measure for the hot/cold concept was still higher than both (0.850). However, for the 5-disease concept analysis, the measure for the hot/cold (0.474) and high blood pressure (0.421) categories were quite similar, as were the measures for the clean/dirty (0.263) and urinary $(0.237)$ 
categories. The degree centrality value for the bitter-sweet disease concept was lowest (0.105). In this post-2000 data set, Aloe vera, Momordica charantia, and Neurolaena lobata had degree centrality values of 1.000 for the 3-disease concept analysis, while Bontia daphnoides and M.charantia had degree centrality values of 0.800 for the 5disease concept analysis.

Lastly, the SNA graphs of the opposite disease concept data show a greater measure of connectedness between fevers and colds in both the pre- and post-2000 results (Figures 6 and 7). Colds had the highest degree centrality values (1.000) in both data sets, while fevers had a degree centrality value of 0.727 for the pre-2000 data and 0.778 for the post-2000 data.

For the opposite disease concepts, no plants had a centrality score of 1.000 , which indicates that none of these plants were cited for all four categories (cold, fever, cough and heat/cooling). In the pre-2000 data, three plants, Abrus precatorius, Chromolaena odorata, and Stachytarpheta jamaicensis had degree centrality scores of 0.750 indicating their connection to three of the four categories. In general, the linkage was between coughs, colds and fevers. S. jamaicensis was the only plant linking heat/cooling to colds and fevers. In the post-2000 data, five of the nine plants were connected to three of the four categories: Cordia curassavica, Leonotis nepetifolia, Momordica charantia, Neurolaena lobata, and Zingiber officinale. In this group, M. charantia was the only plant that was cited for cooling as well as colds and fevers. 


\section{DISCUSSION}

Trinidad and Tobago's Antidiabetic Remedies

The antidiabetic remedies of Trinidad and Tobago are a mixture of Old World and New World species, the majority of which are native or naturalized species that have been recorded for various ailments in T\&T's historical ethnobotanical studies. Yet, of the 99 species, 51 were not recorded as antidiabetics prior to 2000 .

The top plant families represented (Fabaceae, Asteraceae, Rubiaceae, Cucurbitaceae, and Poaceae) are similar to those found in other regional antidiabetic review studies where large plant families like Asteraceae and Fabaceae predominate (Andrade-Cetto and Heinrich, 2005; Giovannini et al. 2016). One broadly-based review of antidiabetic remedies indicated that the plant families most often cited for antidiabetics were (in order) Fabaceae, Asteraceae, Lamiaceae, Liliaceae, Poaceae, and Euphorbiaceae (Marles and Farnsworth 1995). Like T\&T's antidiabetic families, these are some of the most speciose plant families and represent distinct taxonomic clades so that there does not appear to be a narrow chemotaxonomic basis for plant selection.

Although the higher ratio of Neotropical to Paleotropical natives (5:3) is to be expected, it is noteworthy that species of Old World origin (Paleo-Temperate and Paleotropical) still accounted for over $40 \%$ of the remedies cited. This seems to reflect the continued influence of historical and cultural factors in plant selection. One area of influence may be seen among the of food and spice plants in T\&T's antidiabetics. Of the 40 food/spice plants, almost two-thirds were Old-world species. European and Mediterranean food influences were quite evident with the inclusion of Allium sativum, 
Apium graveolens, Petroselinum crispum, and Rosmarinus officinalis. Also, as was observed in the previous chapter, the congruence between T\&T's and India's antidiabetic remedies continued with the inclusion of food/spice plants, such as Curcuma longa, Syzygium cumini, and Zingiber.officinale. Even among the imported non-food species that were cited by herbalists, there were two plants that are well-recognized Ayurvedic diabetes remedies: Gymnema sylvestre and Pterocarpus marsupium (Kapoor 1990).

In comparing the lists of historic and current antidiabetics, (Appendix Sheets 3AD), certain commonalities persisted, such as significant numbers of plants from Asteraceae and Fabaceae, common use of food and spice plants, as well as a higher ratio of Neotropical to Paleotropical species. However, the influence of urbanization or modernization appears to have resulted in many more Temperate climate plants being adopted among the current antidiabetics. To be clear, most of the Temperate-zone species were cited by the urban-based herbalists interviewed in the current field surveys. Therefore it is possible that previous studies that tended to focus on rural communities may not have recorded this body of knowledge. Alternatively, the historical antidiabetic records of other countries around the Caribbean Basin (Payne-Jackson and Alleyne 2004; Rodriguez Martinez 1999; Roth and Lindorf 2002) included some of T\&T's new temperate-zone native remedies, (e.g., Arctostaphylos uva-ursi (L.) Spreng and Taraxacum campylodes G.E.Haglund [synonym: Taraxacum officinale aggr. F.H.Wigg., Prim.]). Thus the process of regional knowledge transfer may also be a factor.

Lastly, in looking at the most cited current remedies (Table 2), the greatest number of citations per plant, even among urban herbalists continued to be for Paleotropical natives that have historically been used as antidiabetics in T\&T. But there 
is evidence that participants are adapting long-used species to address the growing diabetes threat, as almost $50 \%$ of these popular remedies are new citations.

\section{Folk Disease Concepts}

\section{Prevailing Disease Concepts}

In both historical and current ethnobotanical studies, the predominant disease concept associated with antidiabetic remedies in Trinidad and Tobago (T\&T) is the hot versus cold disease concept. The bitter/sweet concept seemed to be less entrenched than the clean/dirty concept, probably because it may have recently arisen as an extension of the folk balancing motif to address the biomedical concept of excess sugar in the blood.

The role of bitter plants in treating hot, infectious conditions, such as malaria is, nonetheless, pervasive across many cultures. Additionally, bitter plant properties also are associated with cleansing as indicated by their popular use as blood purifiers (Etkin et al. 1996; Shepard 2004; van Andel et al. 2012). Quinlan (2004) indicates that among Dominicans, there exist conceptual links between the treatments used to achieve cooling and the treatments for cleansing or washout. Clement et al. (2015) bear out the existence of this idea in T\&T by their record of participants' description of several plants' function as cooling/cleansers. Thus, there is overlap among these disease concepts such that antidiabetic plant selection preferences tend toward plants which are considered to manifest all three modalities of healing.

Of related interest is the folk concept of inflammation, cited by Dominicans, that produces symptoms such as skin eruptions similar to T\&T's heats or heat rash, but is considered as a separate condition from both heat and fever. Quinlan (2004) suggests 
that Dominicans consider diabetes to be a hot condition, though it was not on the list of ailments for which botanical remedies were being used at the time. It is noteworthy, therefore, that the plant remedy most popularly used for inflammation was Momordica charantia, one of T\&T's most cited and bitter-tasting antidiabetic plants

Among the popular antidiabetic remedies, there were more plants from the post2000 data that were aligned to only one disease concept, suggesting a waning in the application of the folk disease models among study participants.

\section{Emerging Disease Concepts}

Several antidiabetic remedies are also used to treat high blood pressure and urinary complaints in Trinidad and Tobago. A comparison of the pre-2000 and post 2000 data indicates an increase in the number of antidiabetic remedies that are applied to the symptoms of urinary complaints and high blood pressure.

The overlap between antidiabetic remedies and treatments for the urinary system may reflect an attempt to address polyuria (excessive urination), one of the predominant disease symptoms of DM, as had been done for many centuries when diabetes was considered a disease of the kidney/urinary system (Eknoyan and Nagy 2005). Yet, both historically and in the recent field studies, the urinary condition for which plants were/are most often used was strangury (Touwaide et al. 1997), or oliguria (Wong 1976), or stoppage of water - as T\&T participants called it - a condition with the opposite problem to polyuria. Potentially, it may be that the plants used to address urinary conditions are seen as fixing the system or restoring whatever imbalance exists rather than necessarily acting in opposition to the observed symptom. 
The association of diabetes remedies with high blood pressure is more likely the result of comorbidity where many patients begin experiencing cardiovascular problems including hypertension as a result of chronic hyperglycemia. Additionally, certain biomedical treatments for one condition may benefit the other-e.g., a reduction in blood glucose concentration could cause the lowering of blood pressure.

Since plant remedies for these two disease categories, high blood pressure and urinary complaints appear to be increasingly aligned to diabetes, it may reflect a move away from an overarching disease concept to the association and treatment of disease by similarity of symptoms. One recent review of antidiabetic remedies used in Central America identified the fact that local remedies were being used to treat diabetes as well as the various body systems affected by diabetes complications including the skin, kidney, and urinary systems (Giovannini et al. 2016).

\section{$\underline{\text { Opposite disease concepts }}$}

Although plants used to treat diabetes seem to be primarily considered to be cooling, cleansing or bitter, these attributes are neither static nor universal. Some of the cooling plants were also prescribed for cold conditions such as coughs and asthma as well as so-called colds in the womb and head. This shift may reflect the distinction participants made between colds perceived to be caused by exposure to the cold environment and those that result from infection. In the latter case, exposure to biomedical concepts such as "germ theory" may factor into the apparent dual concepts. The same can be said for ideas of fever causation and may explain why colds and fevers are often treated with the same plant remedies as the SNA graphs (Figures 6 and 7) showed. One recent study on the hot-cold therapeutics of an indigenous group in Mexico 
highlighted that a similar idea prevails in relation to coughs, such that they may sometimes viewed as being hot (Garcia-Hernandez et al. 2015).

Organoleptic plant properties did seem to be a factor in the plants utilized for the opposing disease factors. Weeds (e.g., Cordia curassavica) and cultivated plants (e.g., Cymbogon citratus) with pungent odors were cited for both colds and fevers. This may reflect the histo-cultural practice of using plants with pungent odors to ward off evil agents that were believed to bring about disease. Of course, it is now known that the odor-producing chemicals of many herbs and spices function as antimicrobials (Billing and Sherman 1998). Whether plant odors served as an initial guide for selection of Neotropical weeds is uncertain, but they are no doubt useful as mnemonic tools.

Parallels in Folk Disease Concepts and Biomedical Mechanisms of DM As mentioned earlier, Quinlan's (2004) work on the Caribbean island of Dominica found that the hot-cold and clean-dirty concepts were associated with "inflammation". The symptoms of this folk inflammation disease are not related to the biomedical condition by the same name. It is considered to be a hot condition, which, like diabetes, is treated with "cooling" remedies. Recent research indicates that diabetes complications may result from an inflammatory response of the body to oxidative stress caused by chronic hyperglycemia (Ceriello and Testa, 2009, Donath and Shoelson 2011). Among the many phytochemicals that have been used against diabetes, polyphenolic compounds have been shown to be useful anti-inflammatory agents that aid in reducing oxidative stress (Leiherer et al. 2013). Peter (2013) reported the presence of polyphenolic compounds among several plants cited as cooling remedies in Barbados. 
Two of these plants (Annona muricata and Leonotis nepetifolia) were also among those cited as cooling plants in T\&T, while in Dominica, A. muricata was cited for inflammation and Citrus aurantifolia was cited for fever (Quinlan 2004). A muricata fruit extract was found to act as an anti-inflammatory agent in rodents where it inhibited the activity of the cyclooxygenase $-2(\mathrm{COX}-2)$ proteins in an edema model (Ishola et al. 2014). Presumably, plants that have been touted as febrifuges or cooling agents may be functioning as anti-inflammatory agents through their antioxidant activity.

Plant agents for blood cleansing include purgatives and laxatives that may be effective in reducing hyperglycemia in the short term because of the evacuation of predigested food products. Even so, the inherent risk of hypoglycemia or possible dehydration does not support regular use of such cathartics for treating a chronic ailment like diabetes.

As regards the sweet-bitter disease concept and possible biomedical applicability, recent research has documented the nature and presence of bitter taste receptors in the mouth, as well as throughout the digestive system (Wu et al. 2002). These bitter taste receptors may produce signal transduction pathways that release glucagon-like peptide 1 (GLP-1), an incretin that stimulates insulin production (Dotson et al. 2008). One study using a bitter plant extract from the root of Gentiana scabra showed a dose-dependent increase in GLP-1 production in experimental mice (Suh et al. 2015). The idea of socalled bitters serving as digestive aids is not new and in some places, aperitifs containing small amounts of bitter plant extracts are still consumed before a meal (Snow and Spelman 2011). As bitter taste receptors have been found in vagus nerve cells, it is 
possible that the physiological effects of bitter plants on digestion and glucose metabolism may extend beyond the GLP-1 transduction pathway (Bone and Mills 2013). Among the most well-known bitter phytochemicals are the sesquiterpene lactones, which are most commonly produced by many members of the Asteraceae family (Chadwick et al. 2013). It is noteworthy, that eight of the antidiabetic plant species of Trinidad and Tobago are members of that family and that one of these plants is the recently adopted Vernonia amygdalina, which is called Nigerian bitterleaf. The bitter native, zebapique (Neurolaena lobata), which also belongs to Asteraceae, had the greatest number of citations (8) for bitterness in the field surveys. Nevertheless, as many bitter phytochemicals can be poisonous (Doughari 2012), the regular use of these bitter remedies for a chronic condition such as diabetes, may pose some risk, unless used in small quantities as part of the regular diet, as is done with $V$. amygdalina among the Hausa of Nigeria (Etkin 2006)

\section{Conclusions}

Trinidad and Tobago's antidiabetic remedies are comprised of almost equal numbers of old and new citations, pre and post 2000. Given the shorter length of the post-2000 period - it seems reasonable to conclude that new botanical remedies are rapidly being adopted, most likely as a result of the growing prevalence of DM.

Among the popular antidiabetics there is a trend toward decreasing alignment with the prevailing folk disease models as evidenced by fewer plants and lower levels of alignment within the post-2000 data. 
To some extent, antidiabetic plant selection seems to reflect the popularity of familiar medicinals, which is based either on their ready accessibility, (e.g., weeds, such as Bidens pilosa and other Asteraceae), multiple uses (e.g., the food and medicinal plant Momordica charantia ) or notable organoleptic properties (e.g., pungent odor/taste of Allium sativum). Among the ninety-nine remedies, thirty-two plants are weeds of disturbed habitats, forty are food/spice plants and altogether about 42 are known for their distinct or pungent odors or bitter tastes. Thus, organoleptic properties appear to be an important determining factor.

Nevertheless, as the notion of a plant's efficacy tends to be more directly associated with its detectable organoleptic properties, folk disease concepts may have been devised as a posteriori mnemonic cues (similar to Doctrine of signatures see Bennett 2007) to capture that knowledge (Etkin 2006). As such, folk disease concepts allow users to successfully identify plants that may have previously shown efficacy and this facilitates the knowledge transmission process. 
Figure 1 - Model of relationship between four bodily humors and the primary qualities of matter as represented in the Hippocratic writing - "On the nature of Man" (adapted from Conrad et al. 1995:25)

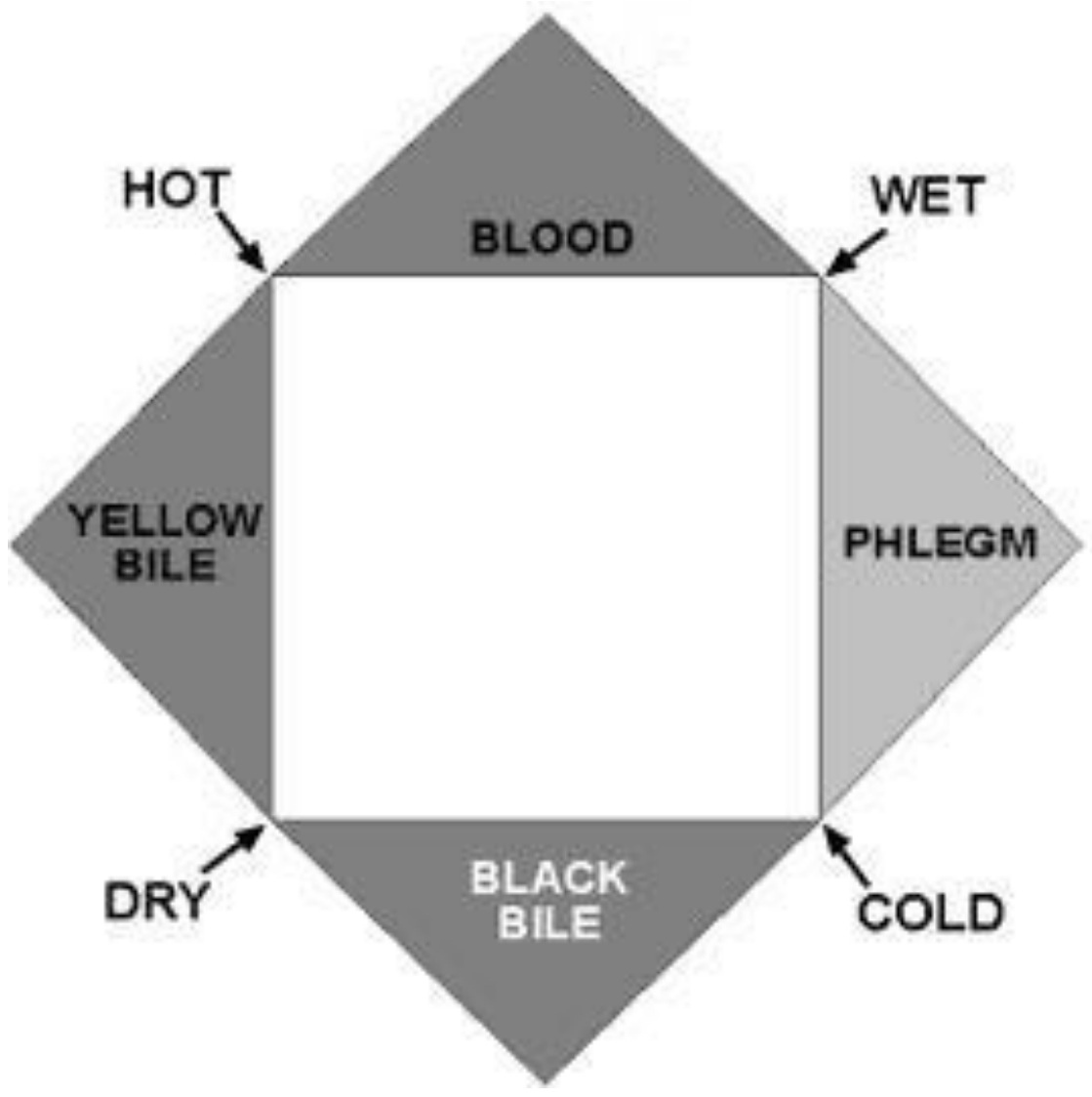


Table 1 - List of 99 plants indicated as diabetes remedies in Trinidad and Tobago from literature and field surveys . (N.B. List excludes any imported non-food species)

\begin{tabular}{|lllll|}
\hline Scientific Name & Family Name & Local Name & Plant Part & Native Range \\
\hline Abrus precatorius L. & Fabaceae & $\begin{array}{l}\text { crab eye/ licorice/ } \\
\text { jumbie bead }\end{array}$ & aerial parts & Paleotropical \\
Ageratum conyzoides (L.) L. & Asteraceae & zeb-a-fam & root & Neotropical \\
Allium cepa L. & Amaryllidaceae & onion & not specified & Uncertain \\
Allium sativum L. & Amaryllidaceae & garlic & not specified & Paleo-Temperate \\
Aloe vera (L.) Burm. f. & Xanthorrhoeaceae & aloes & not specified & Paleo-Temperate \\
Alysicarpus vaginalis (L.) DC & Fabaceae & speed vine & aerial parts & Paleotropical \\
Ananas comosus (L.) Merr. & Bromeliaceae & pineapple & (half ripe) fruit & Neotropical \\
Annona muricata L. & Annonaceae & soursop & leaves & Neotropical \\
Annona squamosa L. & Annonaceae & sugar apple & seeds ( powdered) & Neotropical \\
Antigonon leptopus Hook. \& & Polygonaceae & coralita & vine & Neotropical \\
Arn. & & & & \\
\end{tabular}


Table 1 - (continued)

\begin{tabular}{|c|c|c|c|c|}
\hline Scientific Name & Family Name & Local Name & Plant Part & Native Range \\
\hline Apium graveolens $\mathrm{L}$. & Apiaceae & celery & not specified & Paleo-Temperate \\
\hline Aristolochia rugosa Lam. & Aristolochiaceae & $\begin{array}{l}\text { matroot / bitter } \\
\text { root / annico root }\end{array}$ & roots & Neotropical \\
\hline Aristolochia trilobata $\mathrm{L}$. & Aristolochiaceae & twef / tref & leaf decoctions & Neotropical \\
\hline $\begin{array}{l}\text { Artocarpus altilis (Parkinson ex } \\
\text { F.A.Zorn) Fosberg }\end{array}$ & Moraceae & breadfruit & leaves (yellow) & Paleotropical \\
\hline Avena sativa $\mathrm{L}$. & Poaceae & oats & not specified & Uncertain \\
\hline Averrhoa carambola $\mathrm{L}$. & Oxalidaceae & five fingers & fruit & Paleotropical \\
\hline Azadirachta indica A. Juss & Meliaceae & neem & leaves & Paleotropical \\
\hline Bambusa vulgaris Schrad. & Poaceae & bamboo grass, & not specified & Paleotropical \\
\hline Bauhinia guianensis Aubl. & Fabaceae & $\begin{array}{l}\text { monkey step/ } \\
\text { granny backbone }\end{array}$ & woody vine & Neotropical \\
\hline Bidens pilosa $\mathrm{L}$. & Asteraceae & railway daisy & not specified & Neotropical \\
\hline
\end{tabular}


Table 1 - (continued)

\begin{tabular}{|c|c|c|c|c|}
\hline Scientific Name & Family Name & Local Name & Plant Part & Native Range \\
\hline Bixa orellana $\mathrm{L}$. & Bixaceae & roucou & roots & Neotropical \\
\hline Bontia daphnoides L. & Scrophulariaceae & olive bush & $\begin{array}{l}\text { leaves with young } \\
\text { floral bud }\end{array}$ & Neotropical \\
\hline Brassica oleracea L. var italica & Brassicaceae & broccoli & not specified & Paleo-Temperate \\
\hline $\begin{array}{l}\text { Brassica rapa L. } \\
\quad \text { subsp. chinensis (L.) Hanelt }\end{array}$ & Brassicaceae & pak choy & not specified & Paleo-Temperate \\
\hline $\begin{array}{l}\text { Bryophyllum pinnatum (Lam.) } \\
\text { Oken }\end{array}$ & Crassulaceae & $\begin{array}{l}\text { wonder of the } \\
\text { world }\end{array}$ & leaves (raw) & Paleotropical \\
\hline Cajanus cajan (L.) Millsp. & Fabaceae & pigeon peas & leaves \& stems & Paleotropical \\
\hline Cannabis sativa $\mathrm{L}$. & Cannabaceae & marijuana & leaves & Paleo- Temperate \\
\hline Capraria biflora $\mathrm{L}$. & Scrophulariaceae & ditay payee & not specified & Neotropical \\
\hline Carica papaya L. & Caricaceae & pawpaw & $\begin{array}{l}\text { fruit (green) \& } \\
\text { leaves }\end{array}$ & Neotropical \\
\hline Catharanthus roseus (L.) G. Don & Apocynaceae & $\begin{array}{l}\text { periwinkle / old } \\
\text { maid }\end{array}$ & $\begin{array}{l}\text { flowers (white } \\
\text { variety preferred) }\end{array}$ & Paleotropical \\
\hline
\end{tabular}


Table 1 - (continued)

\begin{tabular}{|c|c|c|c|c|}
\hline Scientific Name & Family Name & Local Name & Plant Part & Native Range \\
\hline Cecropia peltata $\mathrm{L}$. & Urticaceae & bois cano & leaves & Neotropical \\
\hline $\begin{array}{c}\text { Cheilocostus speciosus (J. } \\
\text { Koenig C.D.Specht) }\end{array}$ & Zingiberaceae & cane riviere & stem & Paleotropical \\
\hline $\begin{array}{l}\text { Chromolaena odorata (L.) R.M. } \\
\text { King \& H. Rob. }\end{array}$ & Asteraceae & Christmas bush & flowers & Neotropical \\
\hline Cinnamomum sp. & Lauraceae & cinnamon & $\begin{array}{l}\text { bark (powder) \& } \\
\text { leaf }\end{array}$ & Paleotropical \\
\hline Cissampelos pareira $\mathrm{L}$. & Menispermaceae & pataçon & root & Neotropical \\
\hline Citrus paradisi Macfad. & Rutaceae & grapefruit & fruit (immature) & Neotropical Hybrid \\
\hline Citrus $\mathrm{x}$ aurantium $\mathrm{L}$. & Rutaceae & sour orange & fruit peel & $\begin{array}{l}\text { Paleo-Temperate } \\
\text { Hybrid }\end{array}$ \\
\hline $\begin{array}{l}\text { Cnidoscolus aconitifolius (Mill.) } \\
\text { I. M. Johnst. }\end{array}$ & Euphorbiaceae & chaya & leaves & Neotropical \\
\hline Coccinia grandis (L.) Voigt. & Cucurbitaceae & $\begin{array}{l}\text { parwar/ ivy gourd/ } \\
\text { wild cucumber }\end{array}$ & leaf juice & Paleotropical \\
\hline
\end{tabular}


Table 1 - (continued)

\begin{tabular}{|c|c|c|c|c|}
\hline Scientific Name & Family Name & Local Name & Plant Part & Native Range \\
\hline Cocos nucifera L. & Arecaceae & coconut & $\begin{array}{l}\text { fruit (immature - } \\
\text { skin), dried nut }\end{array}$ & Paleotropical \\
\hline $\begin{array}{l}\text { Cola nitida (Vent.) Schott \& } \\
\text { Endl. }\end{array}$ & Malvaceae & obie seed & seed & Paleotropical \\
\hline $\begin{array}{l}\text { Colubrina arborescens (Mill.) } \\
\text { Sarg. }\end{array}$ & Rhamnaceae & mauby & bark & Neotropical \\
\hline $\begin{array}{l}\text { Cordia curassavica (Jacq.) } \\
\text { Roem. \& Schult. }\end{array}$ & Boraginaceae & black sage & not specified & Neotropical \\
\hline Crescentia cujete L. & Bignoniaceae & calabash & leaves & Neotropical \\
\hline Cucumis sativus L. & Cucurbitaceae & cucumber & fruit & Paleotropical \\
\hline Cucurbita pepo L. & Cucurbitaceae & pumpkin seed & seeds & Neo-Temperate \\
\hline Curcuma longa L. & Zingiberaceae & turmeric & rhizome & Paleotropical \\
\hline Cymbopogon citratus (DC) Stapf & Poaceae & fever grass & leaves & Paleotropical \\
\hline $\begin{array}{l}\text { Dolichandra unguis-cati (L.) } \\
\text { L.G. Lohmann }\end{array}$ & Bignoniaceae & cat's claw & stem and leaves & Neotropical \\
\hline
\end{tabular}


Table 1 - (continued)

\begin{tabular}{|c|c|c|c|c|}
\hline Scientific Name & Family Name & Local Name & Plant Part & Native Range \\
\hline Eclipta prostrata (L.) L. & Asteraceae & congolalla & stem and leaves & Neotropical \\
\hline Eryngium foetidum $\mathrm{L}$. & Apiaceae & $\begin{array}{l}\text { shado beni/ fit } \\
\text { weed }\end{array}$ & leaves & Neotropical \\
\hline Genipa americana L. & Rubiaceae & monkey apple & fruit & Neotropical \\
\hline Gomphrena globosa L. & Amaranthaceae & bachelor button & flowers and leaves & Neotropical \\
\hline Hamelia patens Jacq. & Rubiaceae & wild clover & leaves & Neotropical \\
\hline Hibiscus rosa-sinensis L. & Malvaceae & $\begin{array}{l}\text { double hibiscus/ } \\
\text { arahoo }\end{array}$ & flowers & Paleotropical \\
\hline Ipomoea aquatica Forssk. & Convolvulaceae & kharmi bhaji & $\begin{array}{l}\text { leaves \& tender } \\
\text { stems }\end{array}$ & Paleotropical \\
\hline Jatropha curcas L. & Euphorbiaceae & white physic nut & leaves & Neotropical \\
\hline Justicia secunda Vahl. & Acanthaceae & $\begin{array}{l}\text { St. John bush/ } \\
\text { blood bush }\end{array}$ & not specified & Neotropical \\
\hline Laportea aestuans (L.) Chew & Urticaceae & stinging nettle & $\begin{array}{l}\text { roots (soaked in } \\
\text { vermouth) }\end{array}$ & pantropical \\
\hline
\end{tabular}


Table 1 - (continued)

\begin{tabular}{|c|c|c|c|c|}
\hline Scientific Name & Family Name & Local Name & Plant Part & Native Range \\
\hline Leonotis nepetifolia (L.) R.Br. & Lamiaceae & shandilay & leaves & Paleotropical \\
\hline Lippia alba (Mill.) N.E.Br. & Verbenaceae & santa maria & leaves & Neotropical \\
\hline Mimosa pudica L. & Fabaceae & ti marie & whole plant, roots & Neotropical \\
\hline Momordica charantia $\mathrm{L}$. & Cucurbitaceae & $\begin{array}{l}\text { caraaili/ corailee/ } \\
\text { bitter melon }\end{array}$ & leaves, fruit & Paleotropical \\
\hline Morinda citrifolia $\mathrm{L}$. & Rubiaceae & pain bush/ noni & ripe fruit, leaves & Paleotropical \\
\hline Moringa oleifera Lam. & Moringaceae & saijan & leaves & Paleotropical \\
\hline Morus alba L. & Moraceae & pawi bush & not specified & Paleo-Temperate \\
\hline Musa $\times$ paradisiaca $\mathrm{L}$. & Musaceae & silk fig & leaves & Paleotropical \\
\hline $\begin{array}{l}\text { Neurolaena lobata (L.) R.Br. ex } \\
\text { Cass. }\end{array}$ & Asteraceae & $\begin{array}{l}\text { zeb-a-pik/ } \\
\text { zebapique }\end{array}$ & leaves & Neotropical \\
\hline $\begin{array}{l}\text { Nopalea cochinellifera }(\mathrm{L} .) \\
\quad \text { Salm-Dyck }\end{array}$ & Cactaceae & ratchet & $\begin{array}{l}\text { fresh leaf pads } \\
\text { (blended) }\end{array}$ & Neotropical \\
\hline Olea europaea L. & Oleaceae & olive oil & fruit oil & Paleo-Temperate \\
\hline Parthenium hysterophorus L. & Asteraceae & white top & leaves & Neotropical \\
\hline
\end{tabular}


Table 1 - (continued)

\begin{tabular}{|c|c|c|c|c|}
\hline Scientific Name & Family Name & Local Name & Plant Part & Native Range \\
\hline Paspalum vaginatum $\mathrm{Sw}$. & Poaceae & chien dent & leaves & Paleotropical \\
\hline Passiflora quadrangularis L. & Passifloraceae & $\begin{array}{l}\text { barbadine/ } \\
\text { granadilla }\end{array}$ & leaves & Neotropical \\
\hline Peperomia pellucida (L.) Kunth. & Piperaceae & shining bush & whole plant & Neotropical \\
\hline Persea americana Mill. & Lauraceae & zaboca/ avocado & seed & Neotropical \\
\hline $\begin{array}{l}\text { Petroselinum crispum (Mill..) } \\
\quad \text { Fuss }\end{array}$ & Apiaceae & parsley & not specified & Paleo-Temperate \\
\hline Phaseolus vulgaris L. & Fabaceae & string bean & pods (fresh) & Neotropical \\
\hline $\begin{array}{l}\text { Phyllanthus amarus Schumach } \\
\quad \& \text { Thonn }\end{array}$ & Phyllanthaceae & $\begin{array}{l}\text { seed-under-leaf/ } \\
\text { guen amber faye }\end{array}$ & $\begin{array}{l}\text { whole plant (stem, } \\
\text { leaves and roots) }\end{array}$ & Neotropical \\
\hline Phyllanthus urinaria $\mathrm{L}$. & Phyllanthaceae & seed-under-leaf & not specified & Paleotropical \\
\hline Piper tuberculatum Jacq. & Piperaceae & candle bush & leaves & Neotropical \\
\hline
\end{tabular}


Table 1 - (continued)

\begin{tabular}{|c|c|c|c|c|}
\hline Scientific Name & Family Name & Local Name & Plant Part & Native Range \\
\hline $\begin{array}{l}\text { Pityrogramma calomelanos }(\mathrm{L} .) \\
\quad \text { Link }\end{array}$ & Pteridaceae & $\begin{array}{l}\text { white-back fern/ } \\
\text { stamp fern }\end{array}$ & whole plant & Neotropical \\
\hline Prunus dulcis (Mill.) D.A.Webb & Rosaceae & almonds & nuts & Paleo-Temperate \\
\hline Rhipsalis baccifera & Cactaceae & old man beard & stem and leaves & pantropical \\
\hline Rosmarinus officinalis L. & Lamiaceae & rosemary & not specified & Paleo-Temperate \\
\hline Ruellia tuberosa L. & Acanthaceae & minny root & root, leaves & Neotropical \\
\hline Scoparia dulcis $\mathrm{L}$. & Plantaginaceae & sweet broom & whole herb & Neotropical \\
\hline $\begin{array}{l}{ }^{1} \text { Senna fruticosa (Mill.) H.S. } \\
\text { Irwin \& Barneby }\end{array}$ & Fabaceae & christmas bush & flowers & Neotropical \\
\hline${ }^{1}$ Senna italica Mill. & Fabaceae & senna & not specified & $\begin{array}{l}\text { Paleotropical \& } \\
\text { Paleo-Temperate }\end{array}$ \\
\hline Spermacoce verticillata $\mathrm{L}$. & Rubiaceae & white head broom & whole herb & Neotropical \\
\hline Spiranthes acaulis (Sm.) Cogn. & Orchidaceae & lapsogen & not specified & Neotropical \\
\hline Spondias mombin L. & Anacardiaceae & hog plum & leaves & Neotropical \\
\hline
\end{tabular}


Table $1-$ (continued)

\begin{tabular}{|c|c|c|c|c|}
\hline Scientific Name & Family Name & Local Name & Plant Part & Native Range \\
\hline $\begin{array}{l}\text { Stachytarpheta jamaicensis (L.) } \\
\text { Vahl }\end{array}$ & Verbenaceae & vervine/ vervain & not specified & Neotropical \\
\hline Syzygium cumini (L.) Skeels & Myrtaceae & jamoon & leaves & Paleotropical \\
\hline Tamarindus indica $\mathrm{L}$. & Fabaceae & tambran & leaves, seed & Paleotropical \\
\hline $\begin{array}{l}{ }^{2} \text { Taraxacum campylodes } \\
\text { G.E.Haglund. }\end{array}$ & Asteraceae & dandelion & leaves, root & pan-Temperate \\
\hline Tournefortia hirsutissima $\mathrm{L}$. & Boraginaceae & jigger bush & stem and leaves & Neotropical \\
\hline Urena lobata L. & Malvaceae & koozay mahoe & not specified & pantropical \\
\hline Vernonia amygdalina Delile & Asteraceae & $\begin{array}{l}\text { Nigerian bitterleaf/ } \\
\text { africana }\end{array}$ & leaves & Paleotropical \\
\hline Zingiber officinale Roscoe & Zingiberaceae & ginger & root & Paleotropical \\
\hline
\end{tabular}

1. Originally listed as Cassia spp, these species have been assigned to the genus Senna based on shared floral morphology as described in Irwin and Barneby 1982.

2. Taraxacum campylodes G.E.Haglund is the accepted name for Taraxacum officinale aggr. F.H.Wigg., Prim. 
Table 2 - Most commonly cited antidiabetic plants of Trinidad and Tobago from post-2000 literature and field surveys

\begin{tabular}{|c|c|c|c|c|}
\hline Scientific Name & Family & Native Range & \# Citations & Pre 2000 Citation? \\
\hline Momordica charantia L. & Cucurbitaceae & Paleotropical & 23 & YES \\
\hline Azadirachta indica A. Juss & Meliaceae & Paleotropical & 15 & YES \\
\hline Catharanthus roseus (L.) G. Don & Apocynaceae & Paleotropical & 15 & YES \\
\hline${ }^{1}$ Phyllanthus sp. & Phyllanthaceae & $\begin{array}{l}\text { Paleotropical and } \\
\text { Neotropical }\end{array}$ & 15 & YES \\
\hline Bryophyllum pinnatum(Lam.) Oken & Crassulaceae & Paleotropical & 7 & NO \\
\hline Cinnamomum sp. & Lauraceae & Paleotropical & 7 & NO \\
\hline Gymnema sylvestre (Retz.) R.Br. ex Sm. & Apocynaceae & Paleotropical & 7 & NO \\
\hline Neurolaena lobata (L.) R.Br. ex Cass. & Asteraceae & Neotropical & 7 & YES \\
\hline${ }^{2}$ Taraxacum campylodes G.E.Haglund & Asteraceae & pan-Temperate & 6 & NO \\
\hline Bixa orellana L. & Bixaceae & Neotropical & 5 & YES \\
\hline Aristolochia rugosa Lam. & Aristolochiaceae & Neotropical & 4 & YES \\
\hline Mimosa pudica $\mathrm{L}$. & Fabaceae & Neotropical & 4 & NO \\
\hline Morinda citrifolia $\mathrm{L}$. & Rubiaceae & Paleotropical & 4 & NO \\
\hline Phaseolus vulgaris L. var. vulgaris & Fabaceae & Neotropical & 4 & NO \\
\hline
\end{tabular}


Table 2 - (continued)

\begin{tabular}{|c|c|c|c|c|}
\hline Scientific Name & Family & Native Range & \# Citations & Pre 2000 Citation? \\
\hline Allium sativum $\mathrm{L}$. & Amaryllidaceae & Paleo-Temperate & 3 & $\mathrm{NO}$ \\
\hline Artocarpus altilis (Parkinson ex F.A.Zorn) Fosb & Moraceae & Paleotropical & 3 & YES \\
\hline Bidens pilosa $\mathrm{L}$. & Asteraceae & Neotropical & 3 & YES \\
\hline Bontia daphnoides L. & Scrophulariaceae & Neotropical & 3 & YES \\
\hline Carica papaya $\mathrm{L}$. & Caricaceae & Neotropical & 3 & YES \\
\hline Cecropia peltata $\mathrm{L}$. & Urticaceae & Neotropical & 3 & $\mathrm{NO}$ \\
\hline Colubrina arborescens (Mill.) Sarg. & Rhamnaceae & Neotropical & 3 & YES \\
\hline Petroselinum crispum (Mill..) Fuss & Apiaceae & Paleo-Temperate & 3 & $\mathrm{NO}$ \\
\hline Rhipsalisbaccifera (J.S. Muell) Stearn & Cactaceae & pantropical & 3 & $\mathrm{NO}$ \\
\hline Spermacoce verticillata $\mathrm{L}$. & Rubiaceae & Neotropical & 3 & YES \\
\hline Stachytarpheta jamaicensis L. & Verbenaceae & Neotropical & 3 & YES \\
\hline Tamarindus indica $\mathrm{L}$. & Fabaceae & Paleotropical & 3 & NO \\
\hline
\end{tabular}

1. Phyllanthus amarus and Phyllanthus urinaria are both commonly called seed-under-leaf in T\&T. In the absence of voucher specimens for each citation, all citations for seed-under-leaf were combined.

2. Taraxacum campylodes G.E.Haglund is the accepted name for Taraxacum officinale aggr. F.H.Wigg., Prim. 
Figure 2 - Social Network Analysis (SNA) graph showing connectivity between three disease concepts and antidiabetic plants (Pre-2000 Literature)

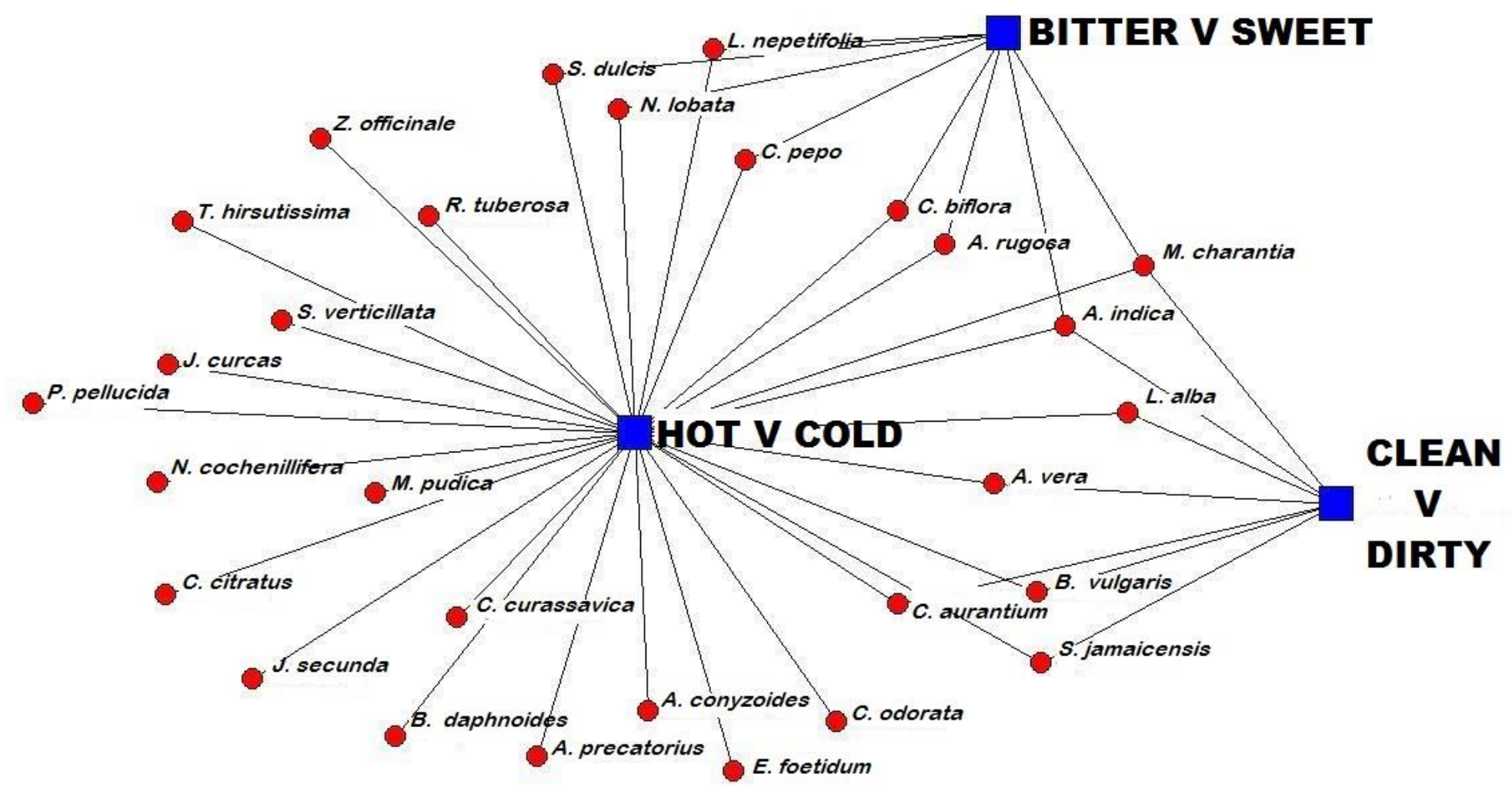


Figure 3 - Social Network Analysis (SNA) graph showing connectivity between three disease concepts and plants (Post -2000 Literature \& Field Data)

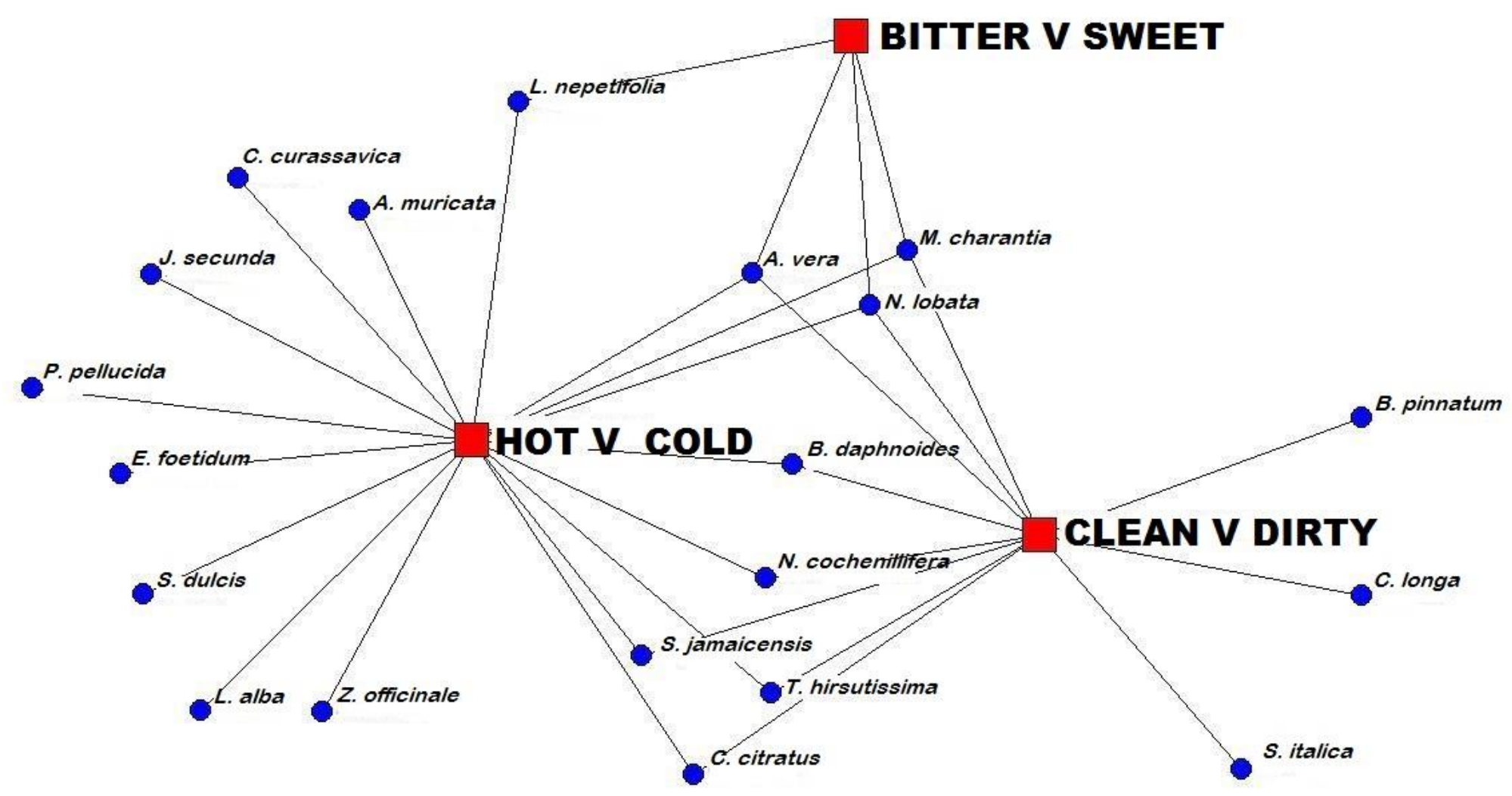


Figure 4 - Social Network Analysis (SNA) graph showing connectivity between five disease concepts and antidiabetic plants (Pre-2000 Literature)

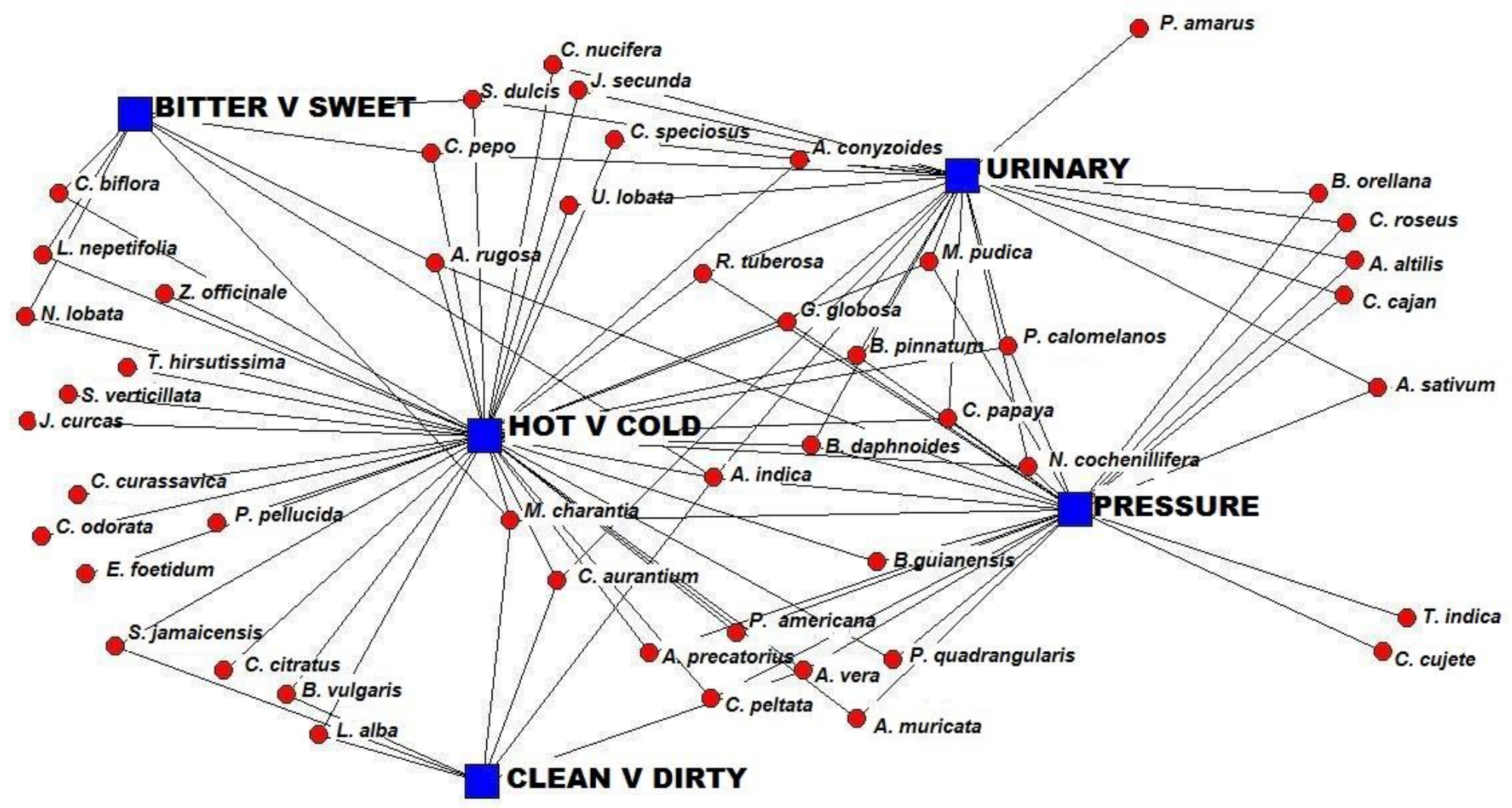


Figure 5 - Social Network Analysis (SNA) graph showing connectivity between five disease concepts and antidiabetic plants (Post-2000 Literature \& Field Data)

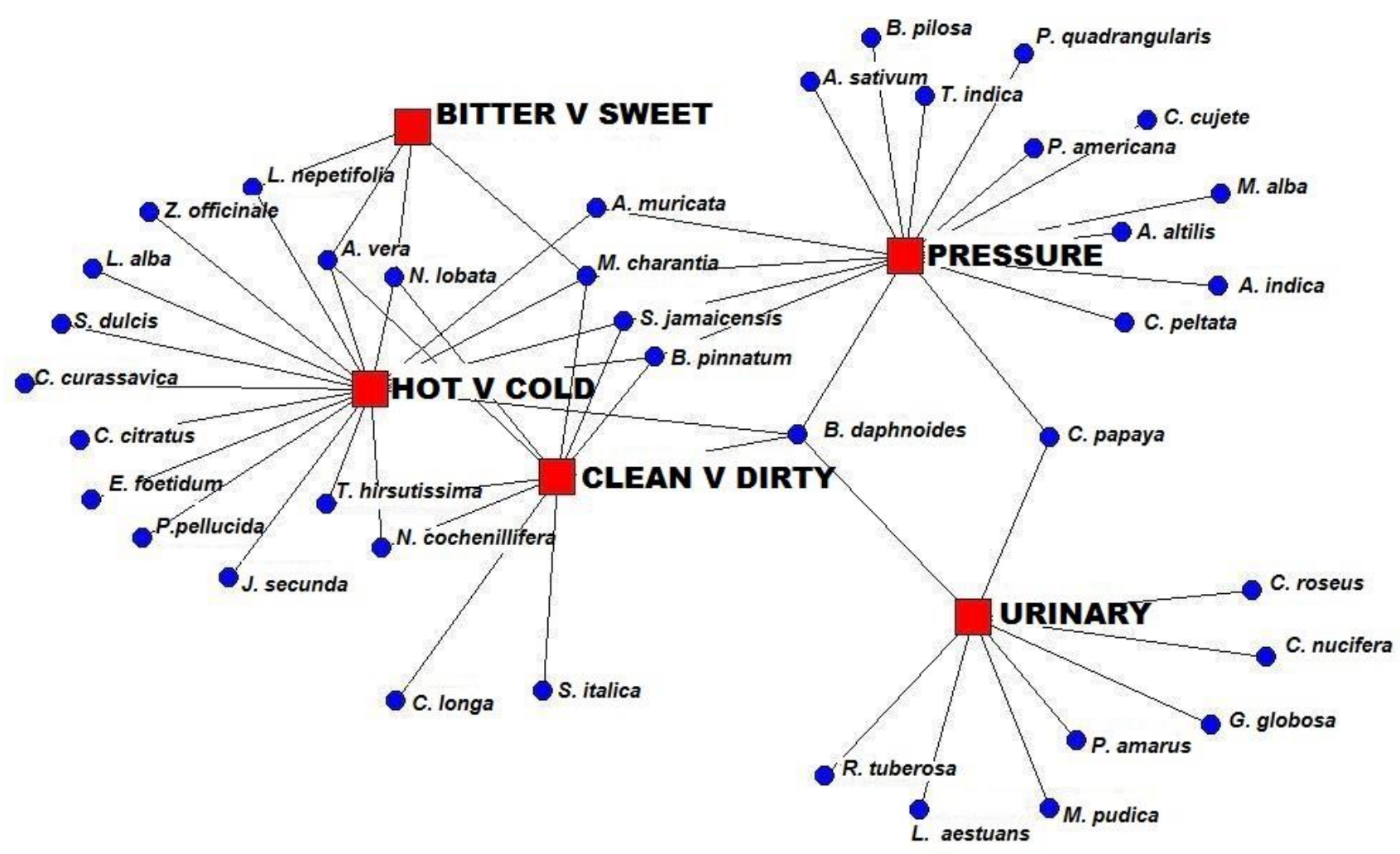


Figure 6 - Social Network Analysis (SNA) graph showing connectivity between contrasting hot vs cold concepts and antidiabetic plants (Pre2000 Literature)

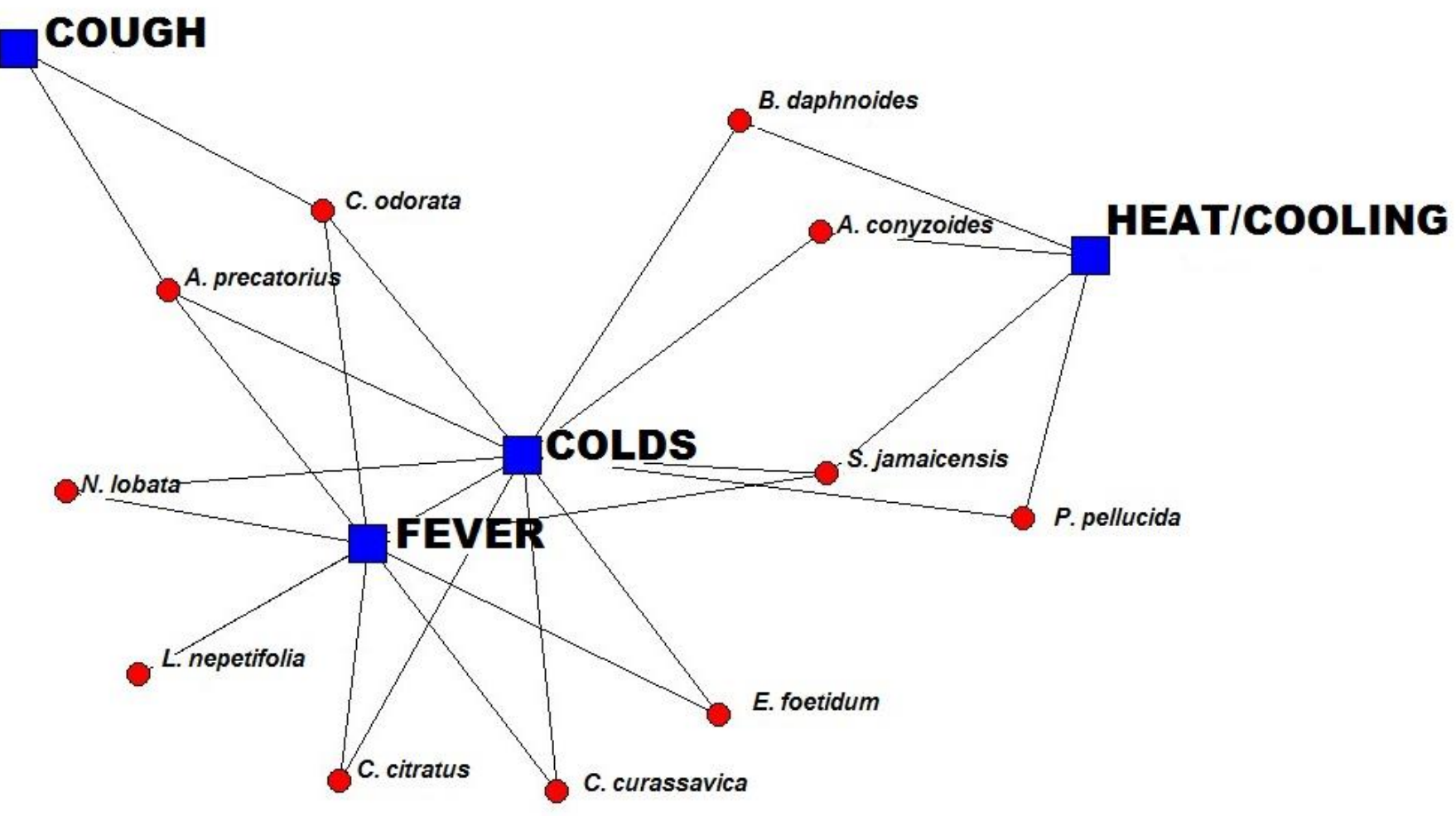


Figure 7 - Social Network Analysis (SNA) graph showing connectivity between contrasting hot vs cold concepts and antidiabetic plants (Post2000 Literature \& Field Surveys)

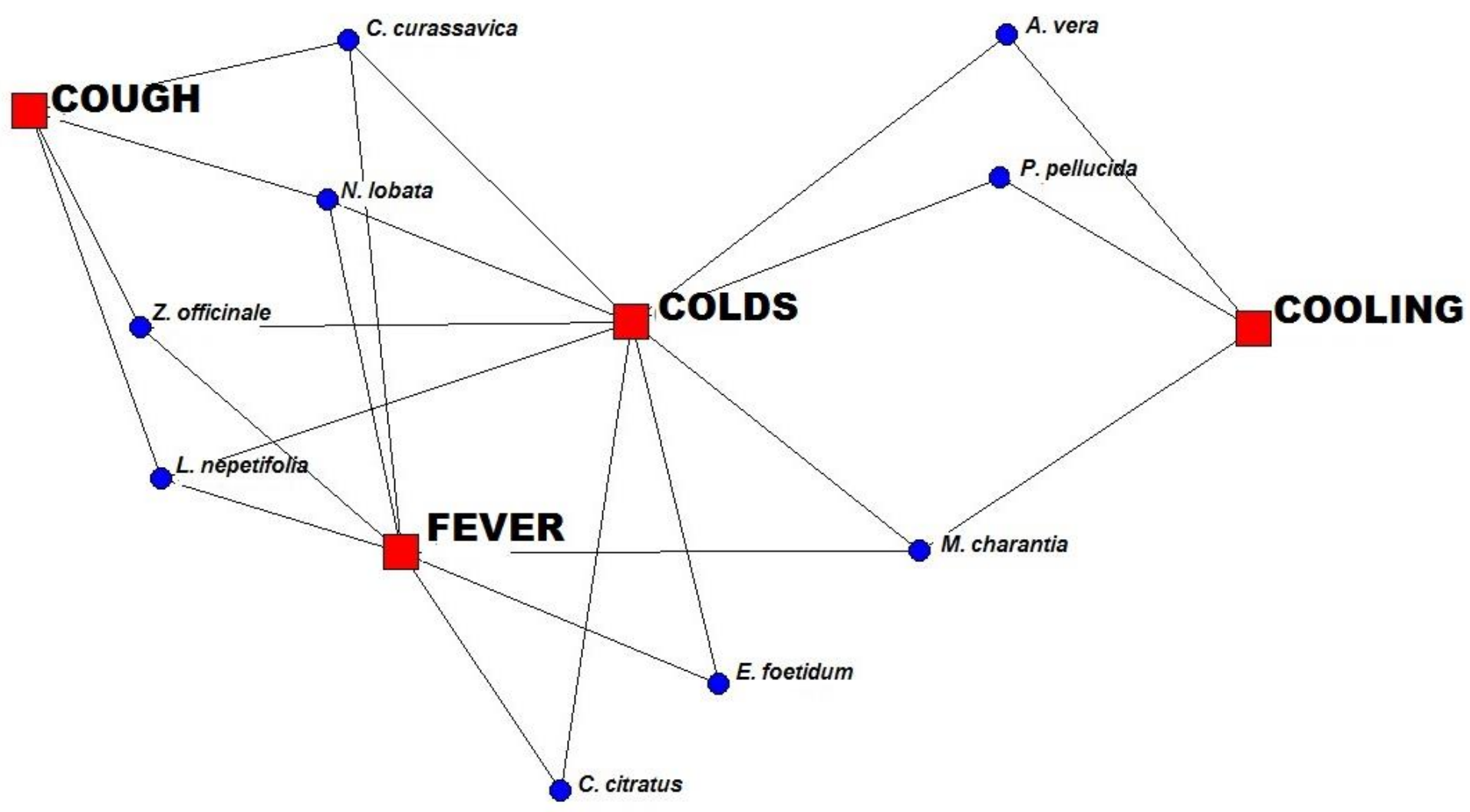




\section{LITERATURE CITED}

Aho, W.R. and K. Minnott. 1977. Creole and Doctor Medicine: Folk Beliefs, Practices and Orientations to modern medicine in a rural and industrial suburban setting in Trinidad and Tobago, W.I. Social Science and Medicine 11:349-355

Andrade-Cetto, A. 2010. Mexican plants traditionally used for the treatment of type 2 diabetes. Pages 191-200 in M. Hiriart-Urdanivia, and J. Mas-Oliva, eds., Advances in Obesity-Diabetes Research at UNAM, Manual Moderno, Mexico.

Andrade-Cetto, A. and M. Heinrich. 2005. Mexican plants with hypoglycaemic effect used in the treatment of diabetes. Journal of Ethnopharmacology 99:325-348.

Ankli, A., Sticher, O., and Heinrich, M. 1999. Yucatec Maya medicinal plants versus nonmedicinal plants: indigenous characterization and selection. Human Ecology 27(4):557-580.

Bailey, C.J., Day, C., and B.A. Leatherdale. 1986. Traditional treatments for diabetes from Asia and the West Indies. Practical Diabetes 3:190-192.

Bennett, B.C., 2007. Doctrine of Signatures: An Explanation of Medicinal Plant Discovery or Dissemination of Knowledge? Economic Botany 61:246-255.

Bernard, H. R. 2002. Research Methods in Anthropology: qualitative and quantitative methods. Walnut Creek, CA: AltaMira Press.

Berlin, B. 1992. Ethnobiological Classification: Principles of Categorization of Plants and Animals in Traditional Societies. Princeton Legacy Library. Princeton University Press, Princeton, NJ.

Berlin, B. 1999. How a Folkbotanical system can be both Natural and Comprehensive: one Maya Indian's view of the Plant World. Pages 71-90 in D.L. Medin, and S. Atran, eds., Folkbiology. MIT Press: Cambridge, MA.

Bhargava, P.N. 1946. Chemical Examination of the fixed oil derived from the wood of Pterocarpus Marsupium Roxb.-Part I. In Proceedings of the Indian Academy of Sciences, Springer India -Section A, (24) 6:496-500.

Bone, K. and S. Mills. 2013 Principles and Practice of Phytotherapy: Modern Herbal Medicine. $2^{\text {nd }}$ ed. Elsevier Health Sciences, New York, NY.

Borgatti, S.P., 2005. Centrality and Network Flow. Social Networks 27:55-71.

Borgatti, S.P., Everett, M.G. and L.C. Freeman. 2002. UCINET for Windows: Software for social network analysis. Version 6.178. Harvard, MA: Analytic Technologies. 
Bryan, C. P. 1930. The Papyrus Ebers: translated from the German version. Garden City Press, Letchworth, Herts.

Caribbean Epidemiology Center (CAREC). 2005. Leading Causes of Death And Mortality Rates (Counts and Rates )in Caribbean Epidemiology Centre Member Countries. CAREC, Trinidad

Ceriello, A., and R.Testa. 2009. Antioxidant anti-inflammatory treatment in type 2 diabetes. Diabetes Care 32( Supp12):S232-S236.

Chadwick, M., Trewin, H., Gawthrop, F., and C. Wagstaff. 2013. Sesquiterpenoids lactones: Benefits to plants and people. International Journal of Molecular Sciences $14: 12780-12805$.

Clement, Y.N., Baksh-Comeau, Y.S. and C.E. Seaforth. 2015. An ethnobotanical survey of medicinal plants in Trinidad. Journal of Ethnobiology and Ethnomedicine 11(1):1.

Conrad, L.I., Neve, M., Nutton, V., Porter, R. and A. Wear. (Eds.) 1995. The Western Medical Tradition: 800BC to AD 1800 Volume 1. Cambridge University Press, Cambridge, UK.

Doughari, J.H. 2012. Phytochemicals: extraction methods, basic structures and mode of action as potential Chemotherapeutic Agents. Pages 1-33 in V. Rao, ed., Phytochemicals: A Global Perspective of their Role in Nutrition and Health. InTechOpen, Rijeka, Croatia.

Donath, M.Y., and Shoelson, S.E., 2011. Type 2 Diabetes is an Inflammatory Disease. Nature Reviews. Immunology 11: 98-107.

Dotson, C.D., Zhang, L., Xu, H., Shin, Y.-K., Vigues, S., Ott, S.H., Elson, A.E.T., Choi, H.J., Shaw, H., Egan, J.M., Mitchell, B.D., Li, X., Steinle, N.I., and S.D. Munger. 2008. Bitter taste receptors influence glucose homeostasis. PLoS One 3:e3974.

Eknoyan, G., and J. Nagy. 2005. A history of diabetes mellitus or how a disease of the kidneys evolved into a kidney disease. Advances in Chronic Kidney Disease 12:223-229.

Etkin, N.L. 1988. Ethnopharmocology: Biobehavioral Approaches in the Anthropological Study of Indigenous Medicines. Annual Review of Anthropology 17: 23-42.

Etkin, N.L., Gollin, L.X., Binnendyk, D. and H. Soselisa. 1996. Ethnomedicine in Maluku, Eastern Indonesia. Cakalele 7:33-50.

Etkin, N.L. 2006. Edible Medicines: An Ethnopharmacology of food. University of Arizona Press, Tucson, AZ.

Foster, G.M. 1976. Disease Etiologies in Non-Western Medical Systems. American Anthropologist 78:773-782. 
Foster, G.M. 1987. On the Origin of Humoral Medicine in Latin America. Medical Anthropology Quarterly 1:355-393.

Freeman, B.C. 1998. Third-World Folk Beliefs and Practices: Haitian Medical Anthropology. La Presse Evangelique, Port-au-Prince, Haiti.

Giovannini, P., Howes, M-J. R., and S.E. Edwards. 2016. Medicinal plants used in the traditional management of diabetes and is sequelae in Central America: A review. Journal of Ethnopharmacology 184:58-71.

Government of Trinidad and Tobago (GOTT) 2008. Population and Vital Statistics Report, Central Statistical Office. Ministry of Planning and Development, GOTT, Port of Spain, Trinidad and Tobago.

GRIN Taxonomy for Plants. 2016. USDA, ARS, National Genetic Resources Program. Germplasm Resources Information Network. National Germplasm Resources Laboratory, Beltsville, Maryland. http://www.ars-grin.gov/ sbmljw/cgibin/paper.pl?language $=$ en $($ September 2015).

Harley, G.W. 1970. Native African Medicine- with special reference to its practice in the Mano tribe of Liberia. Frank Cass \& Co. Ltd., London, UK.

Harris, R. 1991. Local herbs used the Chinese way:(tonics), Book 1. Traditional Chinese Medical Centre, Woodbrook, Trinidad and Tobago.

Heinrich, M. 1998. Indigenous Concepts of Medicinal Plants in Oaxaca, Mexico: Lowland Mixe Plant Classification Based on Organoleptic Characteristics. Journal of Applied Botany-Angewandte Botanik 72:75-81.

International Diabetes Federation (IDF). 2013. IDF Diabetes Atlas, 6th ed. International Diabetes Federation, Brussels, Belgium.

Irwin, H. S. and R. C. Barneby. 1982. The American Cassiinae. Memoirs of the New York Botanical Garden 35:1-918

Junod, S.W. 2000. Alternative Drugs: Homeopathy, Royal Copeland, and Federal Drug Regulation. Pharmacy in History 42:13-35.

Laguerre, M.S. 1987. Afro-Caribbean folk medicine. Bergin-Garvey, South Hadley, MA. Lans, C. 2001. Creole remedies: case studies of ethnoveterinary medicine in Trinidad and Tobago. Wageningen Universiteit, Ph.D. Thesis Publication

Leiherer, A., Mündlein, A., and H. Drexel. 2013. Phytochemicals and their impact on adipose tissue inflammation and diabetes. Vascular Pharmacology 58:3-20. 
Leonti, M., Sticher, O., and M. Heinrich. 2002. Medicinal plants of the Popoluca, Mexico: Organoleptic properties as indigenous selection criteria. Journal of Ethnopharmacology 81:307-315.

Mahabir, N.K. 1991. Medicinal and edible plants used by East Indians of Trinidad and Tobago. Chakra Publishing House, Trinidad,W.I.

Major, R.H. II. 1932 ( $1^{\text {st }}$ ed,. $5^{\text {th }}$ printing $)$. Classic descriptions of disease with biographical sketches of the authors. Charles C. Thomas Publishers Springfield, IL

Medicinal Plant Names Services (MPNS) Portal, Royal Botanic Gardens, Kew, accessed on 28/08/2015. http://mpns.kew.org/mpns-portal/

Murdock, G.P., 1980. Theories of illness: A world survey. University of Pittsburgh Press, Pittsburgh, PA.

Nutton, V. 1995. Medicine in Late Antiquity and the Early Middle Ages. Pages 71-87 in L.I. Conrad, M. Neve, V. Nutton, R. Porter, and A. Wear, eds., The Western Medical Tradition: 800BC to AD 1800 Volume 1. Cambridge University Press, Cambridge, UK.

Ortiz de Montellano, B. 1986. Aztec Sources of Some Mexican Folk Medicine Pages 122 in R.P. Steiner, ed., Folk Medicine: the Art and Science. American Chemical Society, Washington, DC.

Palmer, C., 2004. Plantago spp. and Bidens spp. : A Case Study of Change in Hawaiian Herbal medicine. Journal of Ethnobiology 24:13-31.

Pan American Health Organization (PAHO) \& World Health Organization ( WHO). 2007. Health in the Americas, 2007 edition. Pan American Health Organization, Washington, D.C.

Payne-Jackson, A., and M. C. Alleyne. 2004. Jamaican Folk Medicine: A Source of Healing. University of the West Indies Press, Kingston, Jamaica.

Peter, S. 2013. Medicinal and cooling teas of Barbados. Pages 285-308 in R.Voeks and J. Rashford, eds., African Ethnobotany in the Americas. Springer, New York, NY.

Pieroni, A., Nebel, S., Quave, C., Munz, H., and M. Heinrich. 2002. Ethnopharmacology of liakra: traditional weedy vegetables of the Arbereshe of the Vulture area in southern Italy. Journal of Ethnopharmacology 81:165-185.

Pieroni, A. and B. Torry. 2007. Does the taste matter? Taste and medicinal perceptions associated with five selected herbal drugs among three ethnic groups in West Yorkshire, Northern England. Journal of Ethnobiology and Ethnomedicine 3(1):1. 
Porter, R. 1995. The Eighteenth Century. Pages 371-475 in L.I. Conrad, M. Neve, V. Nutton, R. Porter, and A. Wear, eds., The Western Medical Tradition: 800BC to AD 1800 Volume 1. Cambridge University Press, Cambridge, UK.

Quinlan, M.B. 2004. From the bush: The front line of health care in a Caribbean village. Wadsworth Publishing Company. Belmont, CA.

Santos, S.J., Hurtado-Ortiz, M.T., and C.D. Sneed. 2009. Illness Beliefs Regarding the Causes of Diabetes Among Latino College Students: An Exploratory Factor Analysis. Hispanic Journal of Behavioral Sciences 31:395-412.

Schadewaldt, H. 1989. The history of diabetes mellitus. Pages 43-100 in D. von Engelhardt, ed., Diabetes, its medical and cultural history. Springer-Verlag, Berlin.

Schoenberg, N.E., Amey, C.H., and R.T. Coward. 1998. Stories of meaning: Lay perspectives on the origin and management of noninsulin dependent diabetes mellitus among older women in the United States. Social Science and Medicine 47:2113-2125.

Seaforth, C.E, Adams, C.D., and Y. Sylvester. 1983. A guide to the medicinal plants of Trinidad \& Tobago. Caribbean Industrial Research Institute (CARIRI), Tunapuna, Trinidad and Tobago, W.I.

Seaforth, C.E., Ballah, S., Rollocks, S., and S. Craig-James. 1998. Medicinal Plants used in Tobago. Fitoterapia 69:523-527

Shepard, G.H. 2004. A Sensory Ecology of Medicinal Plant Therapy in two Amazonian Societies. American Anthropologist 106:252-266.

Simpson, G.E. 1962. Folk Medicine in Trinidad. The Journal of American Folklore 75:326-340.

Sivarajan, V.V., and I. Balachandran. 1994. Ayurvedic drugs and their plant sources. Oxford and IBH Publishing, New Delhi, India.

Snow, J. and Spelman, K. 2011. The influence of bitter, aromatic and pungent medicinal plants on gut function. Pages 237-250 in M. Mullin, G.E. Matarese, and L.E. Palmer, eds., Gastrointestinal and Liver Disease Nutrition Desk Reference. CRC Press, Boca Raton, FL.

Stevens, P.F. 2001 onward. Angiosperm Phylogeny Website, Version 12, July 2012. [more or less continuously updated]. http://www.mobot.org/MOBOT/research/APweb/ (September 2015).

Suh, H.-W., Lee, K.-B., Kim, K.-S., Yang, H.J., Choi, E.-K., Shin, M.H., Park, Y.S., Na, Y.-C., Ahn, K.S., Jang, Y.P., Um, J.Y., and H.-J. Jang. 2015. A bitter herbal medicine Gentiana scabra root extract stimulates glucagon-like peptide-1 secretion and regulates blood glucose in db/db mouse. Journal of Ethnopharmacology 172:219-226. 
The Plant List. 2013. The Plant List: A working list of all plant species, Version 1.1. http://www.theplantlist.org/ (September 2015)

Touwaide, A., Pollio, A., Aliotta, G., Piomelli, D. and N.G. De Santo. 1997. Medicinal Plants for the Treatment of Urogenital Tract Pathologies according to Dioscorides' Materia Medica. American Journal of Nephrology 17:241-247.

Tropicos. 2016. Tropicos.org. Missouri Botanical Garden. http://www.tropicos.org (September 2015).

van Andel, T. R. 2000. Non-timber forest products of the North-West District of Guyana. Tropenbos-Guyana Series; 8a, 8b.

van Andel, T., Mitchell, S.,Volpato, G., Vandebroek, I., Swier, J., Ruysschaert, S., Jimenez, C.A.R., and N. Raes. 2012. In search of the perfect aphrodisiac: Parallel use of bitter tonics in West Africa and the Caribbean. Journal of Ethnopharmacology 143:840850.

Volpato, G., and D. Godínez. 2004. Ethnobotany of Pru, A Traditional Cuban Refreshment. Economic Botany 58:381-395.

von Engelhardt, D., Ed. 1989. Diabetes: Its medical and cultural history. Springer-Verlag, Berlin.

Weller, S.C., Baer, R.D., Pachter, L.M., Trotter, R.T., Glazer, M., Garcia De Alba, J.E., and R.E. Klein. 1999. Latino beliefs about diabetes. Diabetes Care 22:722-728.

Whiting, D.R., Guariguata, L., Weil, C., and J. Shaw. 2011. IDF Diabetes Atlas: Global estimates of the prevalence of diabetes for 2011 and 2030. Diabetes Research and Clinical Practice, 94: 311-321.

Wong, W. 1976. Some Folk Medicinal Plants from Trinidad. Journal of Economic Botany 30:103-142

World Health Organization (WHO) 2002. WHO Traditional Medicine Strategy 20022005 World Health Organization, Geneva, Switzerland.

Wu, S.V., Rozengurt, N., Yang, M., Young, S.H., Sinnett-Smith, J., and E. Rozengurt. 2002. Expression of bitter taste receptors of the T2R family in the gastrointestinal tract and enteroendocrine STC-1 cells. Proceedings of the National Academy of Sciences 99:2392-2397.

Zajac, J., Shrestha, A. Patel, P. and L. Poretsky. 2010. The Main Events in the History of Diabetes Mellitus. Pages 3-16 in L. Poretsky, ed., Principles of Diabetes Mellitus. Springer, New York, NY 


\title{
CHAPTER IV
}

\section{A PHYTOCHEMICAL BASIS FOR ANTIDIABETIC PLANT SELECTION IN TRINIDAD AND TOBAGO}

\begin{abstract}
Plants are among the most prolific sources of natural products that humans use to meet their basic needs, including healthcare. When facing new disease threats, humans may seek out natural products from known or new plants. In developing countries where plants are used for basic healthcare needs, the prevalence of Type II diabetes mellitus (T2DM) is increasing. Also increasing is the number of recent ethnobotanical studies that focus on T2DM. Often, the plant species used to treat T2DM are edible plants. Many edible plants have been identified as rich sources of phenolic compounds that, though naturally abundant in higher plants, are likely to be highly selected for in cultivated foods, as they enhance color, scent, and flavor. To ascertain whether selection for phenolic compounds could be guiding the selection of antidiabetic remedies of a developing country, I tested the phenolic content and one antidiabetic property of a subset of the local pharmacopoeia. Of the 16 putative antidiabetics from Trinidad and Tobago that were analyzed, 11 had total phenolic content above 5\% (=50 mg GAE/g DW) and seven showed alpha-glucosidase inhibition at or above 50\%. Cultivated food plants had the highest correlation between their phenolic content and enzyme inhibition activity. As food plants are already selected for safety in consumption, their use as medicinals poses a
\end{abstract}


lower risk to potential users. Also, the cultural acceptance of medicinal food plants increases the likelihood of their sustained use against chronic diseases such as T2DM.

\section{INTRODUCTION}

Plants are prolific sources of a variety of chemicals of which over 200,000 structures have been identified to date (Hartmann 2007). One of the earliest recorded chemicals isolated from a plant was morphine, in 1806 (Hartmann 2007). Subsequently, as more chemicals were identified, many were shown to be critical to plant metabolism, as well as the basic processes of growth and reproduction. However, the particular role of numerous chemical constituents was found to be less critical for basic plant functionality. For this reason, these chemicals were historically referred to as secondary compounds (Firn 2010; Hartmann, 2007; Quirke and Bennett 2007).

Within the last half century, several roles of plant secondary compounds in mediating plant interactions with the biotic and abiotic environment have been elucidated (Hartmann 2007). Therefore, new terms such as allelochemicals or phytoalexins, have

come into use to describe these compounds (Firn 2010; Harborne 1993). Some authors (Dewick 2002; Quirke and Bennett 2007) prefer the term "natural products," as it reflects the significant utility of these chemicals to human survival, including their use as medicinal remedies.

In general, four classes of plant natural products have been recognized, in line with the key secondary metabolic pathways discovered in the majority of higher plants (though it must be noted that some pathways give rise to members from more than one 
group). These four classes are: alkaloids and other nitrogenous compounds; isoprenoids including terpenoids; polyacetylenes or polyketides and lastly, the aromatic-ringed phenolics (Dewick 2002; Harborne 1993; Quirke and Bennett 2007).

Plant Phenolic Compounds

Though terpenoids have the distinction of being the most diverse group of natural products, with over 30,000 recognized structures (Hartmann 2007), phenolics are arguably the group most widely distributed, as Harborne (1994) suggests that any given plant will produce at least 20 major and over 30 minor phenolic compounds.

Plant phenolics are defined as chemicals in which the primary functional group consists of a six-carbon arene ring to which at least one hydroxyl group is attached. Polyphenolics have more than one phenolic moiety, do not include nitrogen within the arene ring, and are produced via the shikimate or phenylpropanoid biosynthetic pathway (Quideau et al. 2011).

Several subgroups of plant phenolics are recognized, including lignans, tannins, phenolic acids, flavonoids, flavonols and flavones. Many of these have been shown to function in herbivory defense, UV protection, structural support, leaf, flower and fruit coloration and various plant scents (Firn 2010; Quideau et al 2011).

Phenolic compounds that are selectively bred in food plants for their role in color, scent and flavor have been acclaimed in the last two decades for their antioxidant properties (Ali Asgar 2013; Quideau et al. 2011;). Antioxidants are suggested to be useful in counteracting the oxidative stress caused by free radicals and are believed to be able to 
ameliorate the molecular and cellular damage that is associated with many chronic ailments, including Type II diabetes (Brownlee 2001; Ceriello 2000).

In nature, one of the most ubiquitous groups of phenolics is the tannins, named for their role in tanning leather (Quideau et al. 2011). Tannins produce the astringent, mouthpuckering sensation associated with red wine or black tea as a result of the complexes they form with proteins (Dewick 2002; Quideau et al. 2011). The interaction of plantleaf tannins with proteins has been considered a general defense strategy against insect herbivory through the tannins' interference with digestive enzymes (Salminen and Karonen 2011). The presumed activity of enzyme-inhibiting compounds in carbohydrate metabolism also has potential application in diabetes treatments (Ali Asgar 2013).

Some recent studies have assessed the phenolic content of various medicinal and food plants and their related antioxidant properties (e.g., Basar et al. 2013; Choudhary and Swarnkar 2011; Daduang et al. 2011; Haminiuk et al. 2012, Maisuthisakul et al. 2007). Though most studies showed a significant relationship between phenolic content and antioxidant properties in vitro, the actual bioavailability of phenolic compounds after digestion is uncertain (Manach et al. 2004). Furthermore, in treating diabetes, antioxidants' activity becomes more critical to the late-stage complications of chronic hyperglycemia where antioxidants are needed to counter the inflammatory response that causes tissue damage (Nicolle et al. 2011).

Meanwhile, several other studies across the globe have suggested some correlation between the phenolic content of edible plants and their digestive enzyme inhibition activity (e.g., Gulati et al. 2012; Koh et al. 2010; Oboh et al. 2015; Podsędek et al. 2014; Ranilla et al. 2010; Sulaiman and Ooi 2014; Wongsa et al. 2012). In these 
studies, the action of the phenolic compounds is said to be preventative, as their effects occur within the gastrointestinal tract, prior to glucose absorption. Hence, this study focuses on the digestive enzyme-inhibition properties of phenolic compounds in selected botanical antidiabetics.

\section{Digestive Enzyme Inhibition as Antidiabetic Action}

The digestive enzymes of interest to my study are the alpha-glucosidase enzymes. In the human body, alpha-glucosidases are produced by cells in the brush-border of the small intestines. The substrates on which these enzymes act are carbohydrates, namely oligo- and di-saccharides, to produce the monosaccharide, glucose - the starting substrate for cellular respiration (Bischoff 1995; Preuss 2009).

Normal glucose metabolism maintains a balanced concentration of glucose in the bloodstream. For individuals with diabetes, glucose metabolism has malfunctioned and results in chronic hyperglycemia, which necessitates treatment strategies such as reducing the quantity of glucose entering the blood. One way to do this is to inhibit carbohydratedigesting enzymes and a few diabetes drugs currently on the market, e.g., acarbose, voglibose and miglitol are designed to do just that (Bischoff 1995; Preuss 2009).

Carbohydrates are comprised of long and short sequences of carbon-ring structures with hydroxyl $(\mathrm{OH})$ groups attached. As this structure is similar to a simple phenolic structure (Figure 1), it would seem theoretically possible that the inhibitory action of phenolic compounds is based on their ability to fit into the active site of carbohydrate-digesting enzymes. 
In reality, there are many different elements involved in this enzyme-inhibitor interaction and these can determine whether competitive or non-competitive inhibition is occurring. Some of the possible factors to be considered in a competitive inhibition scenario are the class of phenolic compound (and hence the presence or absence of glycosides), the presence of ring substitution, and the resulting kinds of intermolecular reactions that facilitate interlocking at the active site. For non-competitive inhibitory activity, the positioning and number of the hydroxyl groups and the hydrophobic or hydrophilic micro-environment created by interaction between hydroxyl groups and the amino-acid residues nearby (which can cause malformation at the enzyme active site) are the key determining factors (Li et al. 2009; Nicolle et al. 2011; Lo Piparo, et al. 2008; Rohn et al. 2002).

One study (Bharatham et al. 2008) which utilized molecular docking software to model enzyme-ligand interactions suggests five pharmacophore features that are likely responsible for the binding between the alpha-glucosidase enzyme from Saccharomyces cerevisiae and inhibitory agents. These were identified as the presence of 3 hydrogenbond-acceptors (HBA), 1 hydrogen-bond donor (HBD), and 1 ring aromatic (RA). The basic structure of phenolic compounds can be expected to match at least four of these features, namely the 3 HBAs via hydroxyl groups and the RA by the arene ring, but this pharmacophore may vary with different enzyme sources.

What is clear is that phenolic compounds of various sizes have been shown to inhibit the activity of digestive enzymes in vitro (Everette et al, 2013; Gao et al. 2004; Li et al. 2009; Lo Piparo et al. 2008), and they may reduce the rate of carbohydrate digestion 
in vivo. This inhibition would mitigate the spike in blood glucose that typically occurs for diabetics after consuming a meal (Ali Asgar 2013).

Non-Target Antidiabetic Effects of Medicinal Food Plants

A number of ethnobotanical studies that focus on diabetes remedies have recently been completed in developing countries around the world, where the prevalence of diabetes is increasing (Chapter 3). Since local pharmacopoeias often mirror the pressing epidemiological issues of a society, it can be inferred that these recent ethnobotanical studies may reflect a process of rediscovery or adaptation of traditional medicines and local food plants to address prevalent ailments, such as diabetes (Trotter 1981).

In Trinidad and Tobago (T\&T), a developing country with almost 15\% prevalence of diabetes (IDF 2015), about 30\% of the published medicinal flora has been cited as putative antidiabetic remedies. An ethnobotanical study published in 1976 cited 15 plants as antidiabetics from a total of 186 recorded species (Wong 1976). Almost 40 years later, another study cited some 30 plants out of the 96 medicinal species recorded (Clement et al. 2015). What is noteworthy about T\&T's putative antidiabetic pharmacopoeia is that it includes many plants that are also used as food, beverages, seasonings and spices.

Bennett and Prance (2000), have discussed the idea that in many societies, the plants in use as medicinals were originally used as food sources. Furthermore, for many of these societies, the dichotomy between food and medicine, which is typical of current Western medical philosophy, does not exist (Etkin 1996; Johns 1990; Pieroni and Price 2006). For these societies, the Hippocratic philosophy espoused in the quote "Let food 
be thy medicine and medicine be thy food" may be more reflective of their approach to healing, often characterized by the prophylactic use of foods considered to have healthendowing properties (Heinrich et al. 2006; Leonti 2012; Vandebroek and Balick 2014).

The current nutraceutical industry has co-opted that idea in the marketing of many so-called "functional foods" and "superfoods", including familiar fruits such as strawberries (Fragaria spp.) alongside exotic fruits like acerola cherry (Malpighia glabra); both these are rich in phenolic compounds (Haminiuk et al. 2012; Lee et al. 2015). Yet, it is worth noting that most fruits and vegetables contain some phenolic compounds and their regular use as part of a normal diet has been shown to be beneficial in preventing Type II DM in at-risk individuals (Tuomilehto et al. 2001, Shashirekha et al. 2015)

This ubiquity of phenolics in food plants, coupled with their potential to inhibit carbohydrate digestion, invites the query as to whether the recognition of non-target effects of ingested local medicinal/food plants may have been a means of discovering new antidiabetic remedies in Trinidad and Tobago. In line with this query, my study aims were to:

1. Measure the total phenolic content of a selection of putative antidiabetic remedies of Trinidad and Tobago

2. Determine an antidiabetic property of the selected plants as measured through in vitro carbohydrate digestive inhibition activity.

3. Identify the relationship between phenolic content and carbohydrate inhibition activity in plant remedies of different sources and uses. 


\section{METHODS}

Selected Plants and Plant Preparation

Sixteen plants that have been indicated as antidiabetics in Trinidad and Tobago

were selected for laboratory analysis (Table 1). Of these plants, 13 are among the list of the current most popular antidiabetic remedies (Chapter 3). The other three plants (Bauhinia guianensis, Eryngium foetidum and Cordia curassavica) were wild-harvested Neotropical natives selected to represent the categories of interest for this analysis, namely, cultivated food plants, wild (weedy) food plants, cultivated medicinals, wild (weedy) medicinals and forest medicinals (further details in results).

Plant materials were collected in Trinidad and Tobago from participants who were interviewed during surveys (See Chapter 3), where quantities for bulk samples received from one participant were insufficient, plant material was sought from another. Voucher specimens were deposited at the local herbarium (TRIN). Bulk samples were processed to remove soil and insects and then placed in cotton bags to be dried. When dried, they were transferred to paper bags, and then shipped to Florida International University in Miami FL, USA.

Plant material was ground using an electric grinder prior to extraction. Where bulk samples from different sources were collected, these were combined during grinding. Aqueous extracts were prepared either as decoctions or infusions using 1 gram of plant matter per $10 \mathrm{~mL}$ of filtered distilled water. Decoctions were made of root, bark and other woody materials by boiling at $100^{\circ} \mathrm{C}$ for $15 \mathrm{~min}$; infusions were made of leaves, flowers and other non-woody parts by steeping for 15 min between 75 and $80^{\circ} \mathrm{C}$. 
Extracts were lyophilized to remove the water and the remaining solids were stored at $4^{\circ} \mathrm{C}$ until use.

\section{Total Phenolic Content}

The lyophilized plant extracts were reconstituted in phosphate-buffered saline (PBS) for a stock concentration of $10 \mathrm{mg} / \mathrm{mL}$. Stock solution was stored at $-4^{\circ} \mathrm{C}$ between each round of trials. Serial dilutions of stock solutions were made in 97mM PBS (pH 6.9) to obtain three working concentrations ranging from $1.0 \mathrm{mg} / \mathrm{mL}$ to $5.0 \mathrm{mg} / \mathrm{mL}$. Plant samples for each set of trials were prepared from the same stock solution and refrigerated between trials.

The procedure for total phenolic analysis was modified from Medina (2011), which uses the Fast Blue BB reagent instead of the Folin Ciocalteu reagent. The diazonium salts of the Fast Blue BB reagent react with phenolic compounds to form azo complexes that can be detected spectrophotometrically (Medina 2011). The original methods were adapted to allow use of a microplate reader. To obtain the initial range of suitable concentrations, the gallic acid standards were tested in test tubes. Gallic acid (GA) (Acros Organics AC220761000) standards were prepared in eight concentrations ranging from $0 \mathrm{ppm}$ to $1000 \mathrm{ppm}$. Then, $1 \mathrm{~mL}$ of each GA standard was mixed in a glass tube with $0.1 \mathrm{~mL}$ of $0.1 \%$ Fast Blue BB reagent (4`-Amino-2`5`-diethoxybenzanilide) (Acros Organics AC191570250) (prepared in 25\% EtOH) and shaken for 1 min. Next, $0.1 \mathrm{~mL}$ of $5 \% \mathrm{NaOH}$ (Acros Organics AC AC424330250) was added to each tube and incubated at room temperature for $90 \mathrm{~min}$. After incubation, three $0.4 \mathrm{~mL}$ aliquots of 
each GA standard were added to a 24-well microplate and the optical density was read using a Powerwave XS Microplate Reader at 420nm.

To test each plant sample, the reaction was set up in 96-well microplates using $50 \mu \mathrm{L}$ of plant sample. Five microliters $(5 \mu \mathrm{L})$ each of the $0.1 \%$ Fast Blue BB Reagent and the $0.5 \% \mathrm{NaOH}$ were added in that order with 1 min of shaking in between. Gallic acid standards at four different concentrations $(50,100,250$ and $500 \mathrm{ppm})$ were also tested with each plate of plant samples. The incubation time, temperature and reading wavelength were the same as previously indicated. All samples and standards were tested in triplicate (three per microplate) with at least three independent trials. For the blanks, PBS buffer was substituted for plant extract. Sample controls were also prepared for each plant extract and contained plant extract and PBS buffer instead of the FBBB and $\mathrm{NaOH}$ reagents.

\section{Alpha-Glucosidase Inhibition Assay}

The lyophilized plant extracts were reconstituted in phosphate-buffered saline (PBS) for a stock concentration of $20 \mathrm{mg} / \mathrm{mL}$. Stock solution was stored at $-4^{\circ} \mathrm{C}$ between each round of trials. Serial dilutions of stock were prepared in 97mM PBS (pH 6.9) to obtain four working concentrations $(0.625 \mathrm{mg} / \mathrm{mL}-5 \mathrm{mg} / \mathrm{mL})$. Plant samples for each round of trials were prepared from the same stock solution and refrigerated between trials.

Analysis of alpha-glucosidase inhibition activity was carried out using methods adapted from Matsui et al. (1996), Li et al. (2009) and Kumar et al. (2012). Specifically, using a 96-well plate, $25 \mu \mathrm{L}$ of plant extract at each of the four concentrations was pre- 
incubated for $10 \mathrm{~min}$ at $37^{\circ} \mathrm{C}$ with $25 \mu \mathrm{L}$ of yeast (Saccharomyces cerevisiae) alphaglucosidase enzyme (MPBiomedical 153487) (0.5Units/mL) dissolved in PBS.

The reaction was started with the addition of $25 \mu \mathrm{L}$ of the chromogenic substrate, $p$-nitrophenyl $\alpha$-D-glucopyranoside ( $p$ NP-G) (Acros Organics AC337150050), to each well. When the enzyme reacts with $p \mathrm{NP}-\mathrm{G}, p$-nitrophenol is released from the attached glycoside, resulting in a color change from yellow to orange, and increase in absorbance.

The microplate was then incubated for $30 \mathrm{~min}$ at $37^{\circ} \mathrm{C}$. To stop the reaction, 100 $\mu \mathrm{L}$ of Tris Base (0.5M) (Fisher Scientific T-395-1) was added to each well. The absorbance was read using a Powerwave XS Microplate Reader at 405nm. Blank wells contained only PBS buffer and $p$ NP-G; control wells contained buffer instead of plant extract, along with enzyme and substrate. Acarbose (LKT Laboratories A0802) was used as a positive control and was tested at the same four concentrations as the plant extracts. Plant extracts and Acarbose were tested in triplicate with at least three independent experimental trials and the average absorbance readings were used.

\section{Data Analysis}

For the total phenolic assay, GA standard concentrations were plotted against the optical density values to obtain a regression line using MS Excel. Linear regression was used to calculate the phenolic content as GA equivalents of each plant sample, using the optical density readings. Adjustments were made to account for the different concentration units used for the GA standards $(\mathrm{ppm}=\mu \mathrm{g} / \mathrm{mL}$ ). Phenolic content was expressed as milligrams (mg) gallic acid equivalents (GAE) per gram (g) dried weight of plant material. 
To identify possible correlations between the antidiabetic properties of the selected plants and their phenolic content, the mean phenolic content was regressed against each plant's enzyme-inhibiting activity using MS Excel. Regression analysis was also done according to plant sub-groupings (eg, food plants, wild plants etc.) to identify any relationships between total phenolic content and enzyme inhibition.

For the alpha-glucosidase inhibition analysis, all absorbance readings were normalized with the sample controls and the mean absorbance values for all replicates and for each trial (for samples and control) were calculated. Percentage Inhibition was calculated using the equation:

$$
[(\mathrm{AbsC}-\mathrm{AbsS}) / \mathrm{AbsC}] \times 100
$$

where $\mathrm{AbsC}=\mathrm{Absorbance}$ of the control and $\mathrm{AbsS}=$ Absorbance of the sample (plant extract or Acarbose). SPSS software was used to compare means of the trials. Mean percentage inhibition value was then determined for each plant and concentration tested.

\section{RESULTS}

Plant Categories, Characteristics and Yields

The sixteen plants selected for analysis represented a cross-section of the types of plants used as antidiabetics in Trinidad and Tobago (Table 1). For edible species, the plant part that was used as food was not necessarily the plant part used as medicine.

The cultivated food/spice plants included the trees Artocarpus altilis, Bixa orellana and Tamarindus indica, while the wild food plants, included the fast-growing pioneer tree Cecropia peltata, the herb Eryngium foetidum and the very common vine 
Momordica charantia. The cultivated medicinal plants included the trees Azdirachta indica, Morinda citrifolia and Bontia daphnoides, while the weedy plants used as medicinals included the shrubs Cordia curassavica, Phyllanthus amarus, Mimosa pudica and Spermacoce verticillata. The other three medicinal species grew in the wild but, unlike the weedy species, did not voluntarily occur outside of forested areas. They were the vine, Aristolochia rugosa, the liana, Bauhinia guianensis and the shrub, Neurolaena lobata.

Thirteen plant families were represented, including Fabaceae (three species) and Rubiaceae (two species). Five species were of Paleotropical origin. When the different species were taken together, all plant parts were used; leaves were the most common part used. For three species, aged (brown or yellowing) leaves were collected for analysis, in accordance with the local folk practice.

Extraction yields ranged from 4 to $24 \%$ by dry weight. Cecropia peltata, one of the three plants for which brown (aged) leaves were used, produced the lowest yield at 4.93\% (Table 1). The roots (Aristolochia rugosa and Bixa orellana) and the liana (Bauhinia guianensis) also had relatively low yields (10-11\%), which is likely because of their insoluble wood content. The highest product yield was from Morinda citrifolia.

Total Phenolic Content and Percentage Enzyme Inhibition

Phenolic compounds were not present in all of the tested antidiabetic plants of Trinidad and Tobago, though the majority (11 of 16) had levels at or above $50 \mathrm{mg}$ gallic acid equivalents (GAE) per g dry weight (DW) $(=5 \%)$ of plant extract. The two plant 
extracts with the highest phenolic contents were Phyllanthus amarus $(114.73 \pm 17.15 \mathrm{mg}$ GAE per g DW) and Tamarindus indica (113.061 $\pm 4.52 \mathrm{mg}$ GAE per g DW).

The alpha-glucosidase inhibition analysis showed that nine of the 16 plants inhibited the enzyme. Seven species showed mean inhibitory activity greater than $50 \%$ at a concentration of $5 \mathrm{mg} / \mathrm{mL}$ (Figure 2). This compared favorably with the positive control, acarbose, which showed a mean inhibitory activity of $61.4 \%$ at the same concentration.

Seven plant extracts that showed total phenolic content $>5 \%$ (Bauhinia guianensis, Bixa orellana, Cecropia peltata, Cordia curassavica, Mimosa pudica, Spermacoce verticillata and Tamarindus indica) also showed medium to high (> 50\%) alphaglucosidase inhibition. However, the overall correlation between phenolic content and alpha-glucosidase percentage inhibition for all 16 plants was low $\left(r^{2}=0.374\right)$ (Figure 3$)$.

The correlation between phenolic content and enzyme inhibition was greater for the group of food plants $\left(r^{2}=0.734\right)$ than for the non-food plants $\left(r^{2}=0.217\right)$ (Figures 45). When the plants were further subdivided according to their typical uses and sources, the correlations between their enzyme inhibition activity and their phenolic content became clearer (Table 2). The highest levels of correlation between alpha-glucosidase inhibition and phenolic content $\left(\mathrm{r}^{2} \geq 0.90\right)$ were for both cultivated and wild food plants, with weedy medicinals also showing high correlation of $\left(\mathrm{r}^{2}=0.828\right)$.

\section{DISCUSSION}

The majority (69\%) of the antidiabetic plants of Trinidad and Tobago tested in this study contained phenolic compounds. However, total phenolic content (TPC) did not 
correlate in every instance with the alpha-glucosidase inhibitory (AGI) activity of each extract. Less than half (44\%) of the tested plants showed appreciable AGI activity (Figures 2 and 3).

Previous studies comparing phenolic content in aqueous extracts of food and medicinal plants have found levels ranging from 2-103 mg GAE/g DW (Ranilla et al. 2010; Wongsa et al. 2012). Ethanolic extracts had levels up to and in excess of $200 \mathrm{mg}$ GAE/g DW (Eldeen et al. 2011; Maisuthisakul et al. 2007). The total phenolic content of my samples ranged from $0-114 \mathrm{mg} \mathrm{GAE/g} \mathrm{DW.}$

I anticipated that the phenolic content of cultivated plants would be the highest, presuming that selective breeding efforts to increase color, flavor and scent would increase the overall content of phenolic compounds. On the other hand, as plants are known to produce higher levels of phenolics in response to environmental stress, such as heat or cold and herbivory, weedy plants of disturbed habitats may potentially contain more phenolic compounds (Kim et al. 2007; Reyes and Zevallos 2003). In my study, the only group of plants with total phenolics at or above the $5 \%$ level (50 mg GAE/g DW) were the weedy medicinals, Cordia curassavica, Mimosa pudica, Phyllanthus amarus, and Spermacoce verticillata. Harborne (1993) describes one study that showed caterpillars that fed on oak (Quercus sp.) leaves during the spring stopped feeding when the tannin content of those leaves reached at or above $5 \%$ of dry weight. It may be that a similar pattern occurs in other plants, especially weedy species that are subject to higher herbivory pressure than cultivated species which are protected with pesticides.

Some of the plants that I tested had previously been analyzed for their phenolic content; however, the plant parts and extraction solvents used were different, so the 
findings are not directly comparable with this study. For example, one study by Choudhary and Swarnkar (2011) that tested the methanolic extract of the leaves of Azadirachta indica and Tamarindus indica indicated total phenolic contents of 42.12 and $4.72 \mathrm{mg} \mathrm{GAE} / \mathrm{g} \mathrm{DW}$, respectively. Another study (Maisuthisakul et al. 2008) tested the ethanolic extracts from the flowers of Azadirachta indica, the fruit of Momordica charantia and the seeds of Tamarindus indica and found their total phenolic content to be 40.3, 50.9 and 40.7 $\mathrm{mg} \mathrm{GAE} / \mathrm{g}$ DW respectively. In my current study, the total phenolic content obtained for the aqueous extracts of leaves or stems of A. indica, M. charantia and T. indica was 51.3, 25.9 and $113.1 \mathrm{mg} \mathrm{GAE} / \mathrm{g}$ DW respectively.

Tests for alpha-glucoside inhibition (AGI) had also previously been done for a few of my selecteted species, as they are also used as antidiabetics in other tropical locations. Among these, Momordica charantia and Azadirachta indica were the most frequently tested, but researchers used different extraction solvents, plant parts and enzyme sources. Most findings showed similarly low AGI activity for both species (Bhat et al. 2011a; Bhat, et al. 2011b; Kazeem et al. 2013; Mata et al. 2013; Matsuura et al. 2002).

To the best of my knowledge, this study is the first record of AGI testing of Bauhinia guianensis (syn. B. excisa and B. manca). B. guianensis is a forest liana native to the Neotropics with records of medicinal use in Brazil as an antidiarrheal, antiasthmatic and antidiabetic and also in treating infections and pain (Pinheiro et al. 2013a \& b). In Guyana \& Suriname, B. guianensis is used to treat diarrhea, fevers, intestinal worms, venereal diseases and as a fish poison (de Filipps et al. 2004). One review identified studies in which $B$. guianensis extracts were found to have analgesic, 
anti-inflammatory and antimalarial properties, though the active chemical compounds were not identified (Cechinel Filho 2009). My findings of high levels of AGI activity $(102 \%)$ coupled with $>5 \%$ phenolic content $(79.5 \mathrm{mg} \mathrm{GAE} / \mathrm{g}$ DW) warrant further study of this plant to identify the phenolic compounds that may be responsible. At the same time, since $B$. guianensis is a forest native whose habit (a liana) may serve a key role in maintaining forest structure; extracts from alternative Bauhinia species that are cultivated ornamentals should be assayed for their AGI activity and phenolic content, so as to reduce the future risk of overharvesting of the forest species.

Two other plants that showed high levels of AGI activity were the weedy shrubs known for their pungent odors, Cordia curassavica and Spermacoce verticillata (99.8 and $97.3 \%$ respectively). Neither of these species has been recorded as antidiabetics outside of the West Indies, though they have been used medicinally to treat diarrhea, fevers, intestinal worms and other infectious diseases (Conserva and Ferreira 2012; Hernandez 2007). Previous studies addressed their antimicrobial activity and their chemical composition and found that both plants produced essential oils comprised mainly of mono- and sesquiterpenes (Conserva and Ferreira 2012; Hernandez 2007). Though my study indicated a higher level of total phenolics in S. verticillata than in $C$. curassavica (71.2 mg GAE/g DW and $55.6 \mathrm{mg} \mathrm{GAE} / \mathrm{g} \mathrm{DW}$ ), no previous studies indentified phenolics in $S$. verticillata, though flavonoids were found in other members of the genus (Conserva and Ferreira 2012). As for C. curassavica, its roots contained cordiaquinones, however, I did not use the roots in my assay (Ioset et al. 2000).

The two plant species with the highest levels of total phenolics, Phyllanthus amarus (114.7 mg GAE/g DW) and Tamarindus indica (113.1 mg GAE/g DW), showed 
distinctly different AGI activity. One study (McDougall et al. 2005) indicates that certain phenolics, e.g., anthocyanins that are important for food color seem to preferentially inhibit alpha-glucosidases, while soluble tannins e.g., ellagitannins are better at inhibiting alpha-amylases. Thus, weedy medicinal plants in which leaf tannins may be more likely to be employed as a defense against generalist herbivory, are suggested to be more likely to act as alpha-amylase inhibitors, whereas fruits, vegetables and other cultivated food plants that are selectively bred to be more attractive (coloration) and palatable (lower tannins) may function more so as AGIs (McDougall et al. 2005). These findings seem to be a possible explanation for the different results for the AGI activity of the medicinal weed, Phyllanthus amarus (37\%) and the cultivated food plant, Tamarindus indica (108\%). P. amarus has been shown to inhibit the alpha-amylase enzyme (Ali et al. 2006).

Cecropia peltata and Bixa orellana had high levels of AGI activity (96.7 and $84.6 \%$ respectively) but different levels of phenolic content (98.5 and $63.8 \mathrm{mg} \mathrm{GAE} / \mathrm{g}$ DW respectively). Both of these species have been used for diabetes and other ailments in Latin America and elsewhere, though for C. peltata, its congeneric C. obtusifolia is more widely known and used (Andrade-Cetto 2010; Ferreira et al. 2012; Nicasio-Torres et al. 2009; Quanico et al. 2008). One study (Nicasio-Torres et al. 2009) of the antidiabetic activity of Cecropia species suggested that the phenolics chlorogenic acid and isoorientin that were isolated from their extracts were responsible for their activity. In the case of B. orellana, its tocopherol (terpenoid-phenolic) and carotenoid (terpenoid) content were suggested to be the basis for its antidiabetic effects (Ferreira et al. 2012; Ponnusamy et al. 2011). 
Three of the plants with the highest alpha-glucosidase inhibition activity (Bauhinia guianensis, Mimosa pudica and Tamarindus indica) are members of the Fabaceae (legume) family. Though only one of these is a food plant, legumes are an important food source in many cultures, and studies have shown that legumes are a significant source of digestive enzyme inhibitors, which function to defend seeds (peas and beans) against pests (Franco et al. 2002). Phaseolus vulgaris, one of the popular antidiabetic remedies of T\&T (Chapter 3) was found to be particularly useful in retarding the development of three species of weevils through its alpha-amylase inhibitors (Ishimoto and Kitamura 1989 in Franco et al. 2002). Another study showed that the proteinaceous inhibitors of $P$. vulgaris can also act against human pancreatic alpha amylase (Nahoum et al. 2000 in Franco et al. 2002). An in vitro analysis of a variety of $P$. vulgaris called cranberry bean showed significant correlation $\left(\mathrm{r}^{2}=0.980\right)$ between its total phenolic content and its alpha-glucosidase activity (Chiang et al. 2014). Other legumes are also known to produce phenolic compounds, such as isoflavones from soy beans (Glycine max) and vitexin from Adzuki beans (Vigna angularis), which are capable of inhibiting alpha-glucosidases (Getek et al. 2014).

In light of the low AGI activity or total phenolic content of several of the plants tested, it must be reiterated, that AGI activity is not the only measure of antidiabetic activity nor is antidiabetic activity restricted to phenolic compounds. Two literature reviews (Jung et al. 2006; Marles and Farnsworth 1995) completed 10-20 years ago indicated hundreds of plants that tested positive for hypoglycemic or antidiabetic activity. The compounds responsible for the reported bioactivity ranged from polysaccharides to peptides, alkaloids and terpenoids, among others (Jung et al. 2006; Marles and 
Farnsworth 1995). Additionally, the range of current diabetes therapeutics that are being marketed further attest to the idea that numerous modalities of action to address diabetes and its complications are possible.

That said, the formidable cost in time and money to find one compound with a single antidiabetic modality, such as AGI activity (Ghani 2015) makes the prospect of reducing the diabetes prevalence in the developing world through the use of drugs very abysmal. Thus the utility of assessing the bioactivity and phytochemistry of culturally familiar medicinal food plants cannot be overstated.

\section{Cultural Considerations}

As more information is coming to light about the mechanism by which phenolics can ameliorate tissue damage resulting from chronic hyperglycemia (Khangholi et al. 2016), there is significant merit to the use of medicinal food plants in the diabetic's diet. Pre-clinical studies of phenolics have shown their ability to mediate the inflammatory response associated with chronic hyperglycemia. In an in vitro model, curcumin, a polyphenol derived from Curcuma longa L., was found to be able to reduce cytokine production in monocytes. Also in diabetic models of neuropathy and nephropathy, sulforaphane, an isothiocyanate found in cruciferous vegetables, was found to be able to reduce the inflammatory damage caused by hyperglycemic conditions (Milagro et al. 2013). In the context of T\&T, Curcuma longa is a key ingredient in the curries that are regularly consumed. Also, two cruciferous vegetables, Brassica oleracea L. var. italica and Brassica rapa L. subsp. chinensis (L.) Hanelt. are among the recent adoptions in the antidiabetic remedies of $\mathrm{T} \& \mathrm{~T}$. 
Diabetes complications have been associated with chronic hyperglycemia that often results from a lengthy postprandial spike in glucose after the consumption of a meal (Madsbad 2016). The incorporation of nutritionally valuable and culturally familiar food plants as a regular part of the dietary regime will ensure a greater likelihood of maintaining normal blood glucose levels and averting the onset of diabetes complications. One study on the consumption of rice and beans found that diabetic patients experienced lower post-prandial glucose spikes when consuming meals of rice and beans as compared to rice alone (Thompson et al. 2012) In T\&T, a popular dish called "pelau" is made by cooking rice together with pigeon peas (Cajanus cajan), another of the recorded antidiabetic remedies (Chapter 3)

As developing countries become urbanized and modernized, the level and type of access to medicinal plants changes and requires adaptation. The four species Phyllanthus amarus, Tamarindus indica, Bixa orellana, and Cecropia peltata are among the 26 most cited antidiabetics of T\&T (Chapter 3) and represent two categories of plants that are suggested to still be accessible to an urbanizing population—cultivated food plants ( $T$. indica and B. orellana) that are often sold in open air markets, and weedy food/medicinals ( P. amarus and C. peltata), that can be found in man-made or disturbed habitats (de Medeiros, et al. 2012; Vandebroek and Balick 2014).

\section{Conclusion}

The outcomes of this analysis suggest that in using food plants, people in T\&T are discovering new ways to treat their diabetes symptoms. This should not be surprising as diabetes treatments involving dietary restrictions were being used prior to the discovery 
of insulin by practitioners such as Karl Petren and Frederick Allen in the early 1900s (Lasker et al. 2010; Wilder in von Engelhardt 1989).

By advocating the use of long-used food plants as antidiabetic remedies, the challenge of safety is almost completely negated, access to remedies is increased, medical costs reduced and the likelihood of sustained use by patients is assured.

Furthermore, opportunities are created for measuring efficacy of local remedies via epidemiological studies that compare diabetes prevalence within and between cultural, economic, and regional subgroups based on the medicinal foods that are consumed. 
Figure 1 Structural models of polyhydroxy compounds: a disaccharide (maltose) and a phenolic compound (quercetin), showing presence of ringed structure and $-\mathrm{OH}$ groups.

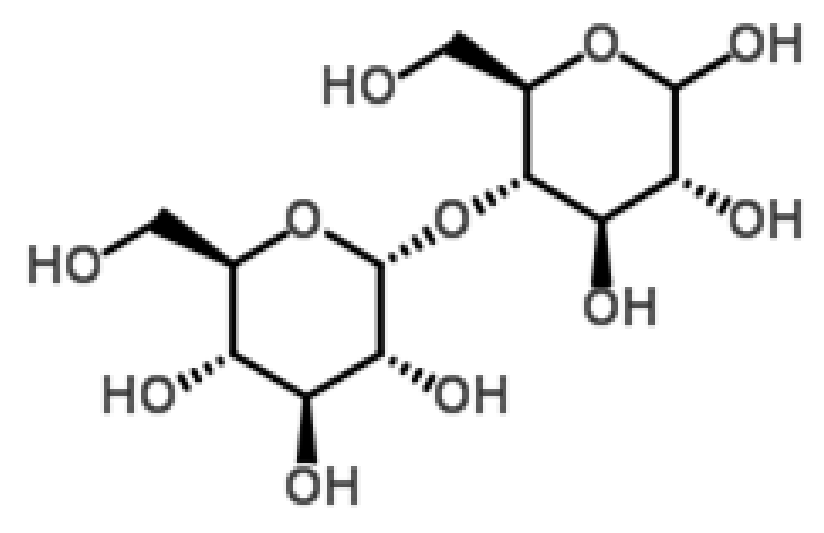

Maltose

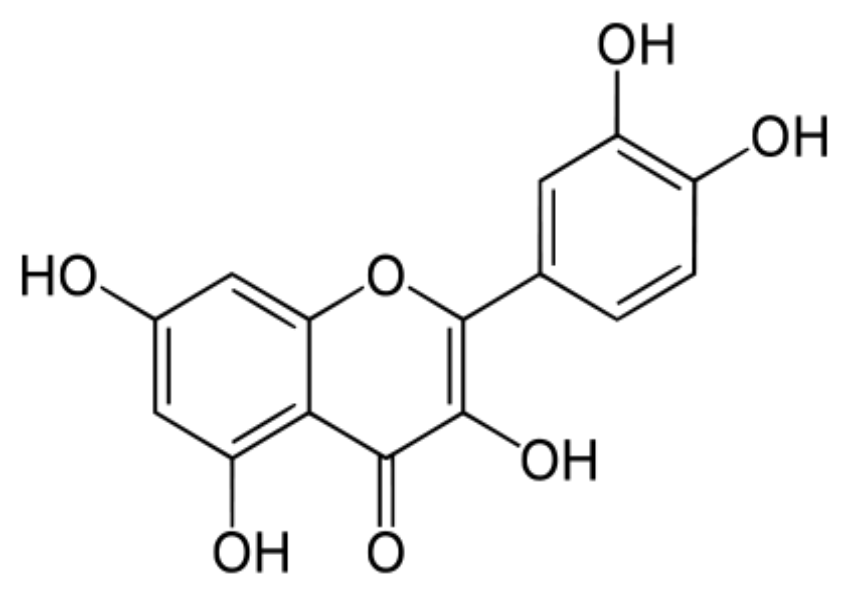

Quercetin 
Table 1 - Plant extraction method and percentage yield of 16 antidiabetic plants from Trinidad and Tobago.

\begin{tabular}{|c|c|c|c|c|c|c|}
\hline Scientific Name & Voucher \# & Family Name & $\begin{array}{l}\text { Common } \\
\text { Name }\end{array}$ & Plant Part & $\begin{array}{l}\text { Means of } \\
\text { Preparation }\end{array}$ & $\begin{array}{l}\text { Extract \% } \\
\text { Yield w/w }\end{array}$ \\
\hline $\begin{array}{l}\text { Aristolochia rugosa Lam. } \\
\text { Artocarpus altilis }\end{array}$ & TTALBR501 & Aristolochiaceae & matroot & roots & Decoction & $10 \%$ \\
\hline $\begin{array}{l}\text { (Parkinson ex F.A. } \\
\text { Zorn) Fosberg }\end{array}$ & TTALBR542 & Moraceae & breadfruit & leaves (aged) & Infusion & $17 \%$ \\
\hline $\begin{array}{l}\text { Azadirachta indica A. } \\
\text { Juss }\end{array}$ & TTALBR531 & Meliaceae & neem & leaves \& twigs & Infusion & $23 \%$ \\
\hline $\begin{array}{l}\text { Bauhinia guianensis } \\
\text { Aubl. }\end{array}$ & TTALBR418 & Fabaceae & $\begin{array}{l}\text { monkey step / } \\
\text { lyan taso }\end{array}$ & liana & Decoction & $10 \%$ \\
\hline Bixa orellana L. & TTALBR413 & Bixaceae & roucou & roots & Decoction & $11 \%$ \\
\hline Bontia daphnoides L. & TTALBR443 & Scrophulariaceae & olive bush & $\begin{array}{l}\text { leaves, stems, } \\
\text { (young) fruit }\end{array}$ & Infusion & $23 \%$ \\
\hline Cecropia peltata L. & TTALBR534 & Urticaceae & $\begin{array}{l}\text { bois cano } \\
\text { /trumpet tree }\end{array}$ & leaves (aged) & Infusion & $4 \%$ \\
\hline $\begin{array}{l}\text { Cordia curassavica } \\
\qquad \text { (Jacq.) Roem. \& } \\
\text { Schult. }\end{array}$ & TTALBR540 & Boraginaceae & black sage & $\begin{array}{l}\text { leaves (green } \\
\text { and aged), } \\
\text { flowers }\end{array}$ & Infusion & $13 \%$ \\
\hline
\end{tabular}


Table 1 - (continued)

\begin{tabular}{|c|c|c|c|c|c|c|}
\hline Scientific Name & Voucher \# & Family Name & $\begin{array}{l}\text { Common } \\
\text { Name }\end{array}$ & Plant Part & $\begin{array}{l}\text { Means of } \\
\text { Preparation }\end{array}$ & $\begin{array}{l}\text { Extract \% } \\
\text { Yield w/w }\end{array}$ \\
\hline Eryngium foetidum $\mathrm{L}$. & TTALBR539 & Apiaceae & $\begin{array}{l}\text { bandhanya / } \\
\text { chadon beni }\end{array}$ & whole plant & Infusion & $22 \%$ \\
\hline Mimosa pudica L. & TTALBR537 & Fabaceae & $\begin{array}{l}\text { ti marie / } \\
\text { sensitive plant }\end{array}$ & whole plant & Infusion & $11 \%$ \\
\hline Momordica charantia $\mathrm{L}$. & TTALBR489 & Cucurbitaceae & carailli & whole vine & Infusion & $12 \%$ \\
\hline Morinda citrifolia L. & TTALBR535 & Rubiaceae & noni & leaves & Infusion & $24 \%$ \\
\hline $\begin{array}{l}\text { Neurolaena lobata (L.) R. } \\
\text { Br. Ex Cass. }\end{array}$ & TTALBR506 & Asteraceae & $\begin{array}{l}\text { zebapique/ zeb- } \\
\text { la-pique }\end{array}$ & leaves & Infusion & $16 \%$ \\
\hline $\begin{array}{l}\text { Phyllanthus amarus } \\
\text { Schumach. \& Thonn. }\end{array}$ & TTALBR536 & Phyllanthaceae & $\begin{array}{l}\text { seed-under-leaf } \\
\text { (red) /gwen- } \\
\text { amba-fei }\end{array}$ & whole plant & Infusion & $12 \%$ \\
\hline Spermacoce verticillata $\mathrm{L}$. & TTALBR538 & Rubiaceae & $\begin{array}{l}\text { white-head } \\
\text { broom }\end{array}$ & $\begin{array}{l}\text { leaves, stems, } \\
\text { flowers }\end{array}$ & Infusion & $11 \%$ \\
\hline Tamarindus indica L. & TTALBR541 & Fabaceae & $\begin{array}{l}\text { tambran / } \\
\text { tamarind }\end{array}$ & leaves & Infusion & $21 \%$ \\
\hline
\end{tabular}

1. Percentage yield of lyophilized aqueous extracts $(\mathrm{n}=1)$ ([final product mass/ initial plant mass extracted] $\mathrm{x} 100)$. 
Figure 2- Total Phenolic Content and Alpha-glucosidase inhibition of 16 antidiabetic plant extracts from Trinidad and Tobago

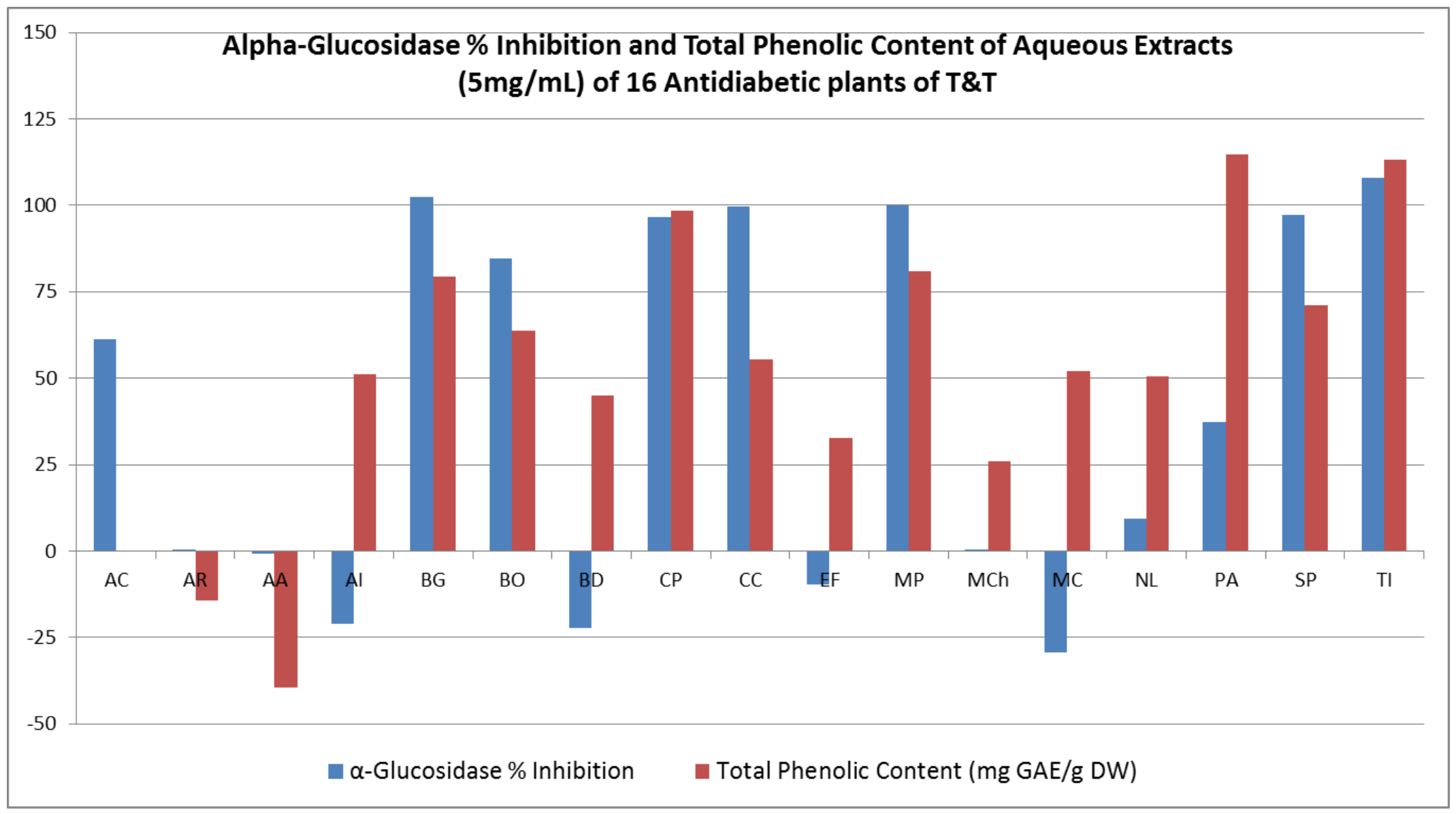

Abbreviations: Acarbose (AC), Aristolochia rugosa (AR), Artocarpus altilis (AA), Azadirachta indica (AI), Bauhinia guianensis (BG), Bixa orellana (BO), Bontia daphnoides (BD), Cecropia peltata (CP), Cordia curassavica (CC), Eryngium foetidum (EF), Mimosa pudica (MP), Momordica charantia (MCh), Morinda citrifolia (MC), Neurolaena lobata (NL), Phyllanthus amarus (PA), Spermacoce verticillata (SP), and Tamarindus indica (TI). 
Figure 3- Relationship between Total Phenolic Content (TPC) and Alpha-glucosidase inhibitory (AGI) activity of $\mathbf{1 6}$ selected plants from Trinidad and Tobago (T\&T)

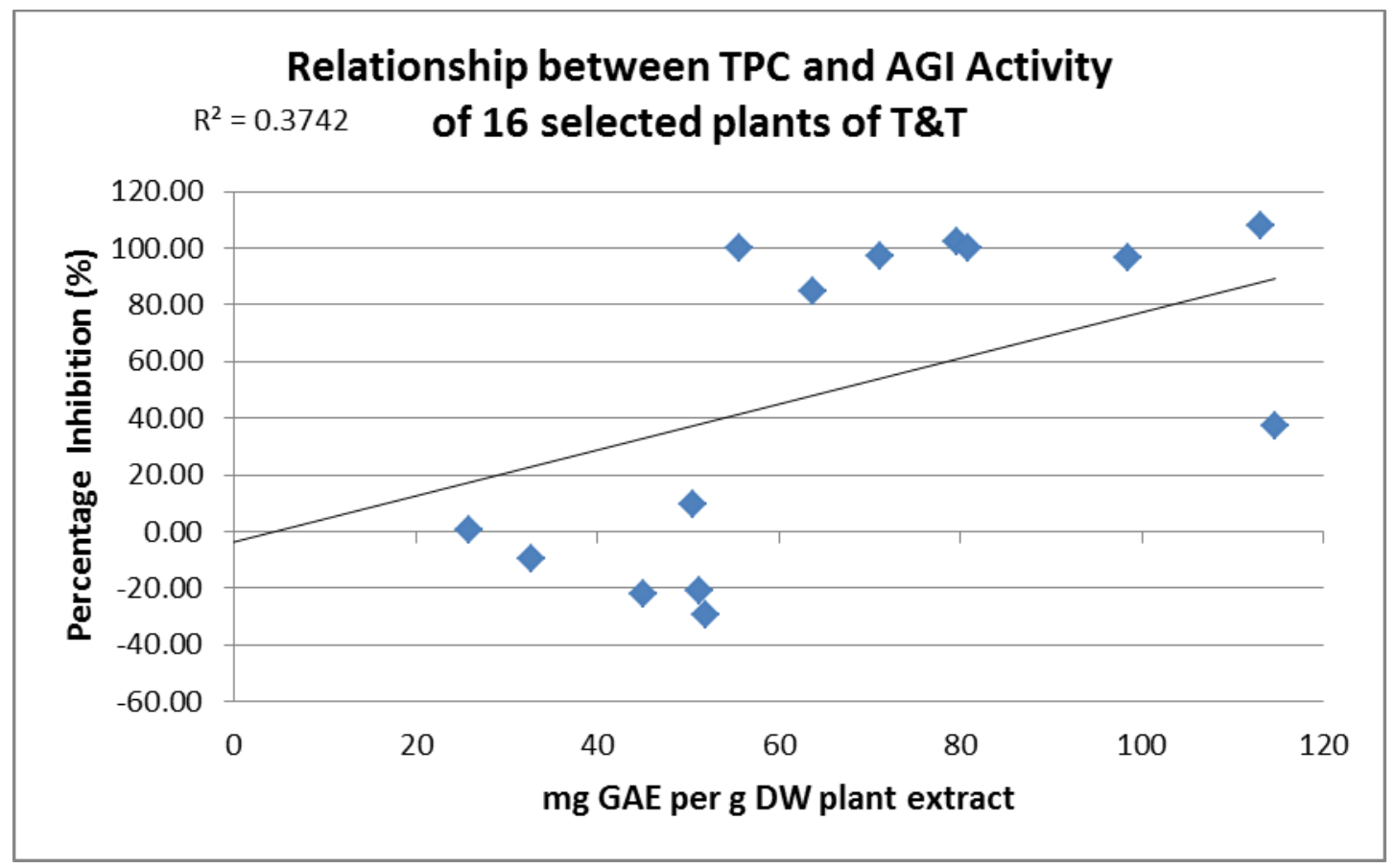

Figure 4- Relationship between Total Phenolic Content (TPC) and Alpha-glucosidase inhibitory (AGI) activity of selected food plants of Trinidad and Tobago (T\&T)

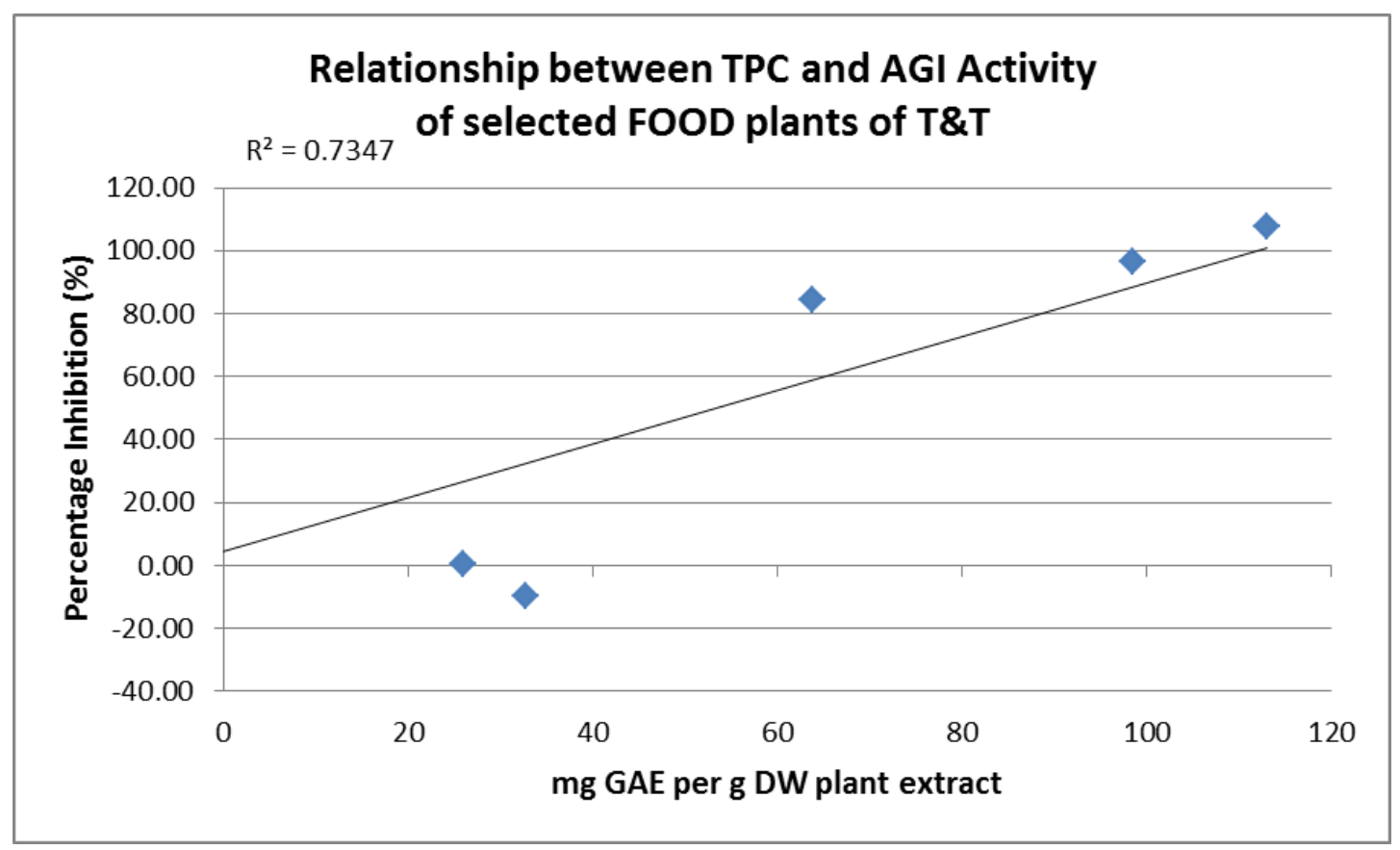


Figure 5- Relationship between Total Phenolic Content (TPC) and Alpha-glucosidase inhibitory (AGI) activity of selected non-food plants of Trinidad and Tobago (T\&T)

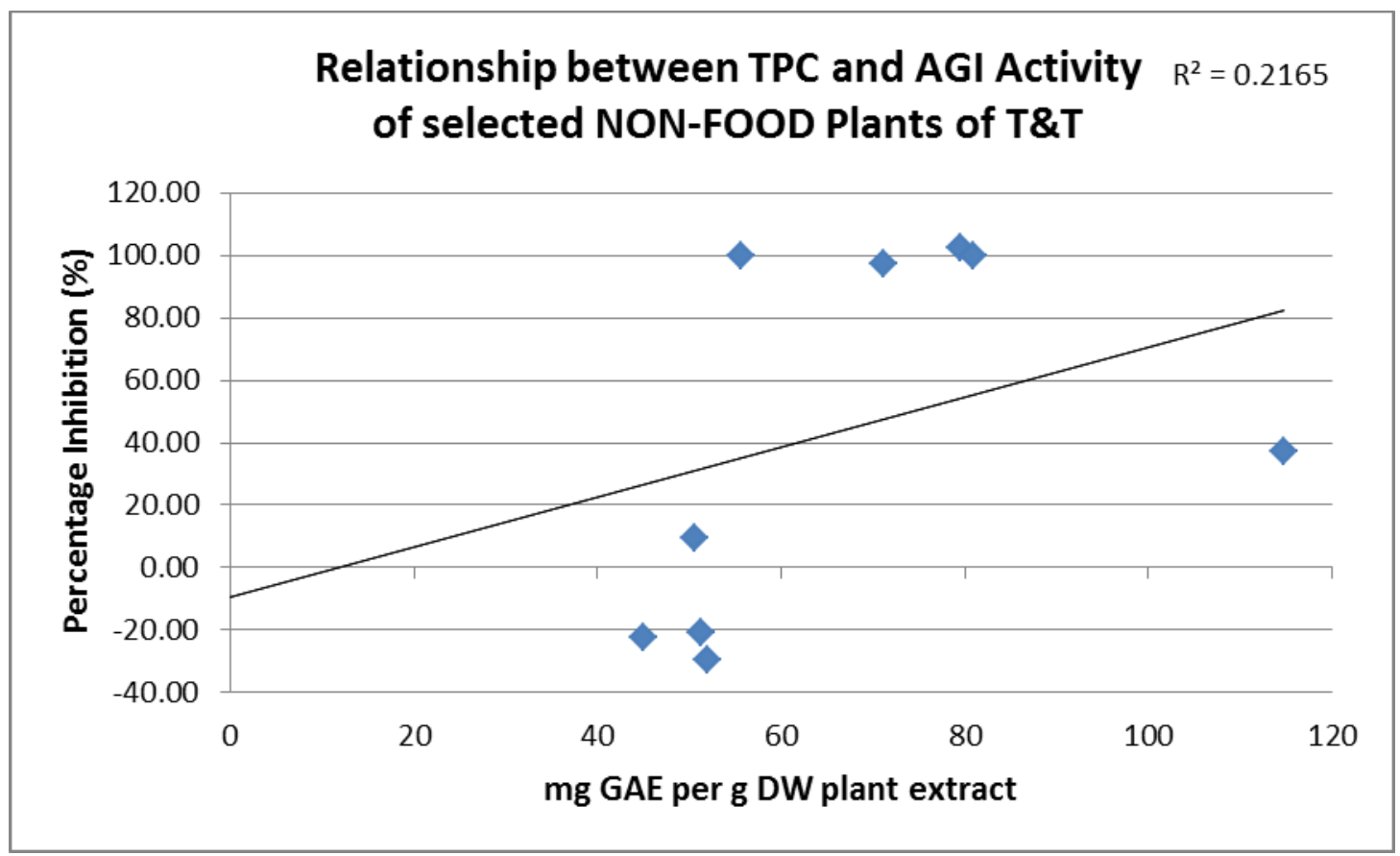

Table 2 - Correlation coefficients ( $\mathrm{r}^{2}$ values) of Alpha-glucosidase inhibition (AGI) and Total Phenolic content (TPC) for tested plant extracts by subgroup

\begin{tabular}{|ll|}
\hline Plant Subgroup & Correlation of AGI-TPC \\
\hline Cultivated Food Plants & 0.987 \\
Wild Food Plants & 0.970 \\
Cultivated Medicinals & 0.217 \\
Weedy Medicinals & 0.828 \\
Forest Medicinals & 0.624 \\
\hline
\end{tabular}




\section{LITERATURE CITED}

Ali Asgar, M. 2013. Anti-Diabetic Potential of Phenolic Compounds: A Review. International Journal of Food Properties 16:91-103.

Ali, H., Houghton, P.J., and A. Soumyanath. 2006. Alpha-Amylase inhibitory activity of some Malaysian plants used to treat diabetes; with particular reference to Phyllanthus amarus. Journal of Ethnopharmacology 107:449-455.

Andrade-Cetto, A. 2010. Mexican plants traditionally used for the treatment of type 2 diabetes. Pages 191-200 in M. Hiriart-Urdanivia, and J. Mas-Oliva, eds., Advances in Obesity-Diabetes Research at UNAM, Manual Moderno, Mexico.

Basar, M.H., Hossain, S.J., Sadhu, S.K., and M.H. Rahman. 2013. A comparative study of antioxidant potential of commonly used antidiabetic plants in Bangladesh. Oriental Pharmacy and Experimental Medicine 13:21-28.

Bennett, B.C., and G.T. Prance. 2000. Introduced Plants in the Indigenous Pharmacopoeia of Northern South America. Economic Botany 54:90-102.

Bharatham, K., Bharatham, N., Park, K.H., and K.W. Lee. 2008. Binding mode analyses and pharmacophore model development for sulfonamide chalcone derivatives, a new class of alpha-glucosidase inhibitors. Journal of Molecular Graphics and Modelling 26: 1202-1212.

Bhat, M., Kothiwale, S.K., Tirmale, A.R., Bhargava, S.Y., and B.N. Joshi. 2011 a. Antidiabetic properties of Azardiracta indica and Bougainvillea spectabilis: In vivo studies in murine diabetes model. Evidence-based Complementary and Alternative Medicine, eCAM 2011: 561625.

Bhat, M., Zinjarde, S.S., Bhargava, S.Y., Kumar, A.R., and B.N. Joshi. 2011b. Antidiabetic Indian plants: A good source of potent amylase inhibitors. Evidence-based Complementary and Alternative Medicine, eCAM 2011:810207.

Bischoff, H. 1995. The mechanism of alpha-glucosidase inhibition in the management of diabetes. Clinical and Investigative Medicine 18:303-311.

Brownlee, M. 2001. Biochemicstry and molecular cell biology of diabetic complications. Nature 414: 813-820.

Cechinel Filho, V. 2009. Chemical Composition and Biological Potential of Plants from the Genus Bauhinia. Phytotherapy Research 23:1347-1354.

Ceriello, A. 2000. Oxidative stress and glycemic regulation. Metabolism: Clinical and Experimental 49:27-29. 
Choudhary, R.K., and P.L. Swarnkar. 2011. Antioxidant activity of phenolic and flavonoid compounds in some medicinal plants of India. Natural Product Research 25: 1101-9.

Clement, Y.N., Baksh-Comeau, Y.S., and C.E. Seaforth. 2015. An ethnobotanical survey of medicinal plants in Trinidad. Journal of Ethnobiology and Ethnomedicine 11: 1.

Conserva, L.M., and J.C. Ferreira. 2012. Borreria and Spermacoce species ( Rubiaceae ): A review of their ethnomedicinal properties , chemical constituents , and biological activities. Pharmacognosy Review 6: 46-55.

Daduang, J., Vichitphan, S., Daduang, S., Hongsprabhas, P., and P. Boonsiri. 2011. High phenolics and antioxidants of some tropical vegetables related to antibacterial and anticancer activities. African Journal of Pharmacy and Pharmacology 5: 608-615.

de Filipps, R.A., Maina, S.L. and J. Crepin. 2004. Medicinal Plants of the Guianas (Guyana, Surinam, French Guiana). Washington, DC: Smithsonian Institution.

de Medeiros, P.M., Soldati, G.T., Alencar, N.L., Vandebroek, I., Pieroni, A., Hanazaki, N. and U.P. de Albuquerque. 2012. The use of medicinal plants by migrant people: adaptation, maintenance, and replacement. Evidence-based Complementary and Alternative Medicine, eCAM 2012:807452.

Dewick, P.M. 2002. Medicinal natural products: a biosynthetic approach. West Sussex, England: John Wiley \& Sons.

Eldeen, I.M.S., Seow, E.M., Abdullah, R. and S.F. Sulaiman. 2011. In vitro antibacterial, antioxidant, total phenolic contents and anti-HIV-1 reverse transcriptase activities of extracts of seven Phyllanthus sp. South African Journal of Botany 77:75-79.

Etkin, N.L. 1996. Medicinal cuisines: Diet and Ethnopharmacology. International Journal of Pharmacognosy 34: 313-326.

Everette, J.D., Walker, R.B., and M.S. Islam. 2013. Inhibitory activity of naturally occurring compounds towards rat intestinal alpha-glucosidase using p-nitrophenyl- $\alpha-\mathrm{d}-$ glucopyranoside (PNP-G) as a Substrate. American Journal of Food Technology 8:65-73.

Ferreira, J.M., Sousa, D.F., Dantas, M.B., Fonseca, S.G.C., Menezes, D.B., Martins, A.M.C., and M.G.R. De Queiroz. 2012. Effects of Bixa orellana L. seeds on hyperlipidemia. Phytotherapy Research 27: 144-147.

Firn, R. 2010. Nature's chemicals: the natural products that shaped our world. Oxford, UK: Oxford University Press.

Gao, H., Nishioka, T., Kawabata, J., and T. Kasai. 2004. Structure-activity relationships for alpha-glucosidase inhibition of baicalein, 5,6,7-trihydroxyflavone: the effect of A-ring substitution. Bioscience, Biotechnology, and Biochemistry 68: 369-375. 
Ghani, U. 2015. Re-exploring promising $\alpha$-glucosidase inhibitors for potential development into oral anti-diabetic drugs: Finding needle in the haystack. European Journal of Medicinal Chemistry 103:133-162.

Gulati, V., Harding, I.H., and E.A. Palombo. 2012. Enzyme inhibitory and antioxidant activities of traditional medicinal plants: potential application in the management of hyperglycemia. BMC Complementary and Alternative Medicine 12: 77.

Haminiuk, C.W.I., Maciel, G.M., Plata-Oviedo, M.S.V., and R.M. Peralta. 2012. Phenolic compounds in fruits - an overview. International Journal of Food Science \& Technology 47: 2023-2044.

Harborne, J. 1993. Introduction to ecological biochemistry, 4th ed. Academic Press, London, UK.

Harborne, J.B. 1994. Do Plant Polyphenols Play a Role in Ecology? Acta Horticulturae $381: 36-45$.

Hartmann, T. 2007. From waste products to ecochemicals: Fifty years research of plant secondary metabolism. Phytochemistry 68: 2831-2846.

Heinrich, M., Nebel, S., Leonti, M., Rivera, D., Obo, N.C. 2006. Local foodnutraceuticals: bridging the gap between local knowledge and global needs. Forum Nutrition 59: 1-17

Hernandez, T., Canales, M., Teran, B., Avila, O., Duran, A., Garcia, A.M., Hernandez, H., Angeles-Lopez, O., Fernandez-Araiza, M., Avila, G. 2007. Antimicrobial activity of the essential oil and extracts of Cordia curassavica (Boraginaceae). Journal of Ethnopharmacology 111: 137-141.

International Diabetes Federation. 2013. IDF Diabetes Atlas, 6th ed. Brussels, Belgium: International Diabetes Federation.

Ioset, J.R., Marston, A., Gupta, M.P. and K. Hostettmann. 2000. Antifungal and larvicidal cordiaquinones from the roots of Cordia curassavica. Phytochemistry 53:613617.

Johns, T. 1990. With bitter herbs they shall eat it: Chemical ecology and the origins of human diet and medicine. Tucson, AZ: University of Arizona Press.

Jung, M., Park, M., Lee, H.C., Kang, Y.-H., Kang, E.S., and S.K. Kim. 2006.

Antidiabetic agents from medicinal plants. Current Medicinal Chemistry 13: 1203-1218.

Kazeem, M.I., Dansu, T.V., and S.A. Adeola. 2013. Inhibitory Effect of Azadirachta indica A. Juss Leaf Extract on the Activities of alpha-Amylase and alpha-Glucosidase. Pakistan Journal of Biological Sciences 16: 1358-1362. 
Khangholi, S., Majid, F.A.A., Berwary, N.J.A., Ahmad, F., and R.B.A. Aziz. 2016. The Mechanisms of Inhibition of Advanced Glycation End Products Formation through Polyphenols in Hyperglycemic Condition. Planta Medica 82: 32-45.

Kim, H.-J., Fonseca, J.M., Choi, J.-H. and C. Kubota. 2007. Effect of methyl jasmonate on phenolic compounds and carotenoids of romaine lettuce (Lactuca sativa L.). Journal of Agricultural and Food Chemistry 55, 10366-10372.

Koh, L.W., Wong, L.L., Loo, Y.Y., Kasapis, S., and D. Huang. 2010. Evaluation of Different Teas against Starch Digestibility by Mammalian Glycosidases. Journal of Agricultural and Food Chemistry 58: 148-154.

Kumar, D., Kumar, H., Vedasiromoni, J.R., and B.C. Pal. 2012. Bio-assay guided isolation of a glucosidase inhibitory constituents from Hibiscus mutabilis leaves. Phytochemical Analysis 23: 421-425.

Lasker, S.P., McLachlan, C.S., Wang, L., Ali, S.M.K., and H.F. Jelinek. 2010. Discovery, treatment and management of diabetes. Journal of Diabetology 1: 1.

Lee, Y.H., Choo, C., Watawana, M.I., Jayawardena, N., V.Y. Waisundara. 2015. An appraisal of eighteen commonly consumed edible plants as functional food based on their antioxidant and starch hydrolase inhibitory activities. Journal of the Science of Food and Agriculture 95: 2956-2964.

Leonti, M. 2012. The co-evolutionary perspective of the food-medicine continuum and wild gathered and cultivated vegetables. Genetic Resources and Crop Evolution 59: $1295-1302$.

Li, H., Song, F., Xing, J., Tsao, R., Liu, Z., and S. Liu. 2009. Screening and Structural Characterization of Alpha-Glucosidase Inhibitors from Hawthorn Leaf Flavonoids Extract by Ultrafiltration LC-DAD-MSn and SORI-CID FTICR MS. Journal of the American Society for Mass Spectrometry 20: 1496-1503.

Li, Y.Q., Zhou, F.C., Gao, F., Bian, J.S., and F. Shan. 2009. Comparative evaluation of quercetin, isoquercetin and rutin as inhibitors of alpha-glucosidase. Journal of Agricultural and Food Chemistry 57: 11463-11468.

Lo Piparo, E., Scheib, H., Frei, N., Williamson, G., Grigorov, M., and C.J. Chou. 2008. Flavonoids for controlling starch digestion: Structural requirements for inhibiting human $\alpha$-amylase. Journal of Medicinal Chemistry 51: 3555-3561.

Madsbad, S. 2016. Impact of postprandial glucose control on diabetes-related complications: How is the evidence evolving? Journal of Diabetes and its Complications 30: $374-385$. 
Maisuthisakul, P., Suttajit, M., and R. Pongsawatmanit. 2007. Assessment of phenolic content and free radical-scavenging capacity of some Thai indigenous plants. Food Chemistry 100: 1409-1418.

Maisuthisakul, P., Pasuk, S., and P. Ritthiruangdej. 2008. Relationship between antioxidant properties and chemical composition of some Thai plants. Journal of Food Composition and Analysis 21: 229-240.

Manach, C., Scalbert, A., Morand, C., Rémésy, C., and L. Jiménez. 2004. Polyphenols: Food sources and bioavailability. American Journal of Clinical Nutrition 79: 727-747.

Mata, R., Cristians, S., Escandón-Rivera, S., Juárez-Reyes, K., and I. Rivero-Cruz. 2013. Mexican antidiabetic herbs: Valuable sources of inhibitors of $\alpha$-glucosidases. Journal of Natural Products 76: 468-483.

Matsui, T., Yoshimoto, C., Osajima, K., Oki, T., and Y. Osajima. 1996. In vitro survey of alpha-glucosidase inhibitory food components. Bioscience, Biotechnology, and Biochemistry 60: 2019-2022.

Matsuura, H., Asakawa, C., Kurimoto, M., and J. Mizutani. 2002. $\alpha$-Glucosidase Inhibitor from the Seeds of Balsam Pear ( Momordica charantia) and the Fruit Bodies of Grifola frondosa. Bioscience, Biotechnology and Biochemistry 66: 1576-1578.

McDougall, G.J., Shpiro, F., Dobson, P., Smith, P., Blake, A., and D. Stewart. 2005. Different polyphenolic components of soft fruits inhibit $\alpha$-amylase and $\alpha$-glycosidase. Journal of Agricultural and Food Chemistry 53: 2760-2766.

Medina, M.B. 2011. Simple and Rapid Method for the Analysis of Phenolic Compounds in Beverages and Grains. Journal of Agricultural and Food Chemistry 59: 1565-1571.

Milagro, F.I., Mansego, M.L., De Miguel, C., and J.A. Martínez. 2013. Dietary factors, epigenetic modifications and obesity outcomes: Progresses and perspectives. Molecular Aspects of Medicine 34: 782-812.

Nicasio-Torres, M.D.P., Erazo-Gomez, J.C., and F. Cruz-Sosa. 2009. In vitro propagation of two antidiabetic species known as guarumbo: Cecropia obtusifolia and Cecropia peltata. Acta Physiologiae Plantarum 31: 905-914.

Nicolle, E., Souard, F., Faure, P., and A. Boumendjel. 2011. Flavonoids as promising lead compounds in type 2 diabetes mellitus: molecules of interest and structure-activity relationship. Current Medicinal Chemistry 18: 2661-2672.

Oboh, G., Ademosun, A.O., Akinleye, M., Omojokun, O.S., Boligon, A.A., and M.L. Athayde. 2015. Starch composition, glycemic indices, phenolic constituents, and antioxidative and antidiabetic properties of some common tropical fruits. Journal of Ethnic Foods 2: 64-73. 
Pieroni, A. and L.L. Price. 2006. Eating and healing: Traditional food as medicine. Binghamton, NY: Food Products Press.

Pinheiro, E.A.A., Carvalho, J.M., Dos Santos, D.C.P., Feitosa, A.O., Marinho, P.S.B., Guilhon, G.M.S.P., Santos, L.S., De Souza, A.L.D., and A.M.D.R. Marinho. 2013a. Chemical constituents of Aspergillus sp EJC08 isolated as endophyte from Bauhinia guianensis and their antimicrobial activity. Anais da Academia Brasileira de Ciencias 85: 1247-1252.

Pinheiro, E.A.A., Carvalho, J.M., Santos, D.C.P., Feitosa, A.O., Marinho, P.S.B., Guilhon, G.M.S.P., Souza, A.D.L., Silva, F.M.A., and A.M.R. Marinho. 2013b.

Antibacterial activity of alkaloids produced by endophytic fungus Aspergillus sp. EJC08 isolated from medical plant Bauhinia guianensis. Natural Product Research 27(18):16331638.

Podsędek, A., Majewska, I., Redzynia, M., Sosnowska, D., and M. Koziołkiewicz. 2014. In vitro inhibitory effect on digestive enzymes and antioxidant potential of commonly consumed fruits. Journal of Agricultural and Food Chemistry 62: 4610-4617.

Ponnusamy, S., Ravindran, R., Zinjarde, S., Bhargava, S., and A. Ravi Kumar. 2011. Evaluation of traditional Indian antidiabetic medicinal plants for human pancreatic amylase inhibitory effect in vitro. Evidence-based Complementary and Alternative Medicine, eCAM2011:515647.

Preuss, H.G. 2009. Bean amylase inhibitor and other carbohydrate absorption blockers: effects on diabesity and general health. Journal of the American College of Nutrition 28: 266-276.

Quanico, J.P., Amor, E.C. and G.G. Perez. 2008. Analgesic and Hypoglycemic Activities of Bixa orellana , Kyllinga monocephala and Luffa acutangula. Phillipine Journal of Science 137: 69-76.

Quideau, S., Deffieux, D., Douat-Casassus, C. and L. Pouységu. 2011. Plant Polyphenols: Chemical Properties, Biological Activities, and Synthesis. Angewandte Chemie International Edition 50: 586-621.

Quirke, M.J.E. and B.C. Bennett. 2007. Chapter 4. Chemistry of Natural Products, in Environmental and Ecological Sciences, Engineering and Technology Resource, edited by B.C. Bennett, in Encyclopedia of Life Support Systems (EOLSS), Developed under the Auspices of the UNESCO, Eolss Publishers, Paris, France, [http://www.eolss.net].

Ranilla, L.G., Kwon, Y.I., Apostolidis, E. and K. Shetty. 2010. Phenolic compounds, antioxidant activity and in vitro inhibitory potential against key enzymes relevant for hyperglycemia and hypertension of commonly used medicinal plants, herbs and spices in Latin America. Bioresource Technology 101: 4676-4689. 
Rohn, S., Rawel, H.M., and J. Kroll. 2002. Inhibitory effects of plant phenols on the activity of selected enzymes. Journal of Agricultural and Food Chemistry 50: 3566-3571.

Salminen, J.-P., and M. Karonen. 2011. Chemical ecology of tannins and other phenolics: we need a change in approach. Functional Ecology 25: 325-338.

Shashirekha, M.N., Mallikarjuna, S.E., and S. Rajarathnam. 2015. Status of Bioactive Compounds in Foods, with Focus on Fruits and Vegetables. Critical Reviews in Food Science and Nutrition 55: 1324-1339.

Sulaiman, S.F., and K.L. Ooi. 2014. Antioxidant and $\alpha$-glucosidase inhibitory activities of 40 tropical juices from Malaysia and identification of phenolics from the bioactive fruit juices of Barringtonia racemosa and Phyllanthus acidus. Journal of Agricultural and Food Chemistry 62: 9576-85.

Thompson, S. V, Winham, D.M., and A.M. Hutchins. 2012. Bean and rice meals reduce postprandial glycemic response in adults with type 2 diabetes: a cross-over study. Nutrition Journal 11: 23.

Trotter, R.T. 1981. Folk remedies as indicators of common illnesses: Examples from the United States-Mexico border. Journal of Ethnopharmacology 4: 207-221.

Tuomilehto, J., Lindstrom, J., Eriksson, J.G., Valle, T.T., Hamalainen, H., IlanneParikka, P., Keinanen-Kiukaanniemi, S., Laasko, M., Louheranta, A., Rastas, M., Salminen, V. and M. Uusitupa. 2001. Prevention of Type 2 Diabetes Mellitus By Changes in Lifestyle Among Subjects With Impaired Glucose Tolerance. The New England Journal of Medicine 344: 1343-1350.

Vandebroek, I., and M. J. Balick. 2014. Lime for Chest Congestion, Bitter Orange for Diabetes: Foods as Medicines in the Dominican Community in New York City.

Economic Botany 68: 177-189.

Wilder, R.M. 1989. Karl Petren: A Leader in Pre-Insulin Dietary Therapy of Diabetes. Pages 405-407 in D. von Engelhardt, ed., Diabetes, its medical and cultural history. Springer-Verlag, Berlin, Germany.

Wong, W. 1976. Some Folk Medicinal Plants from Trinidad. Journal of Economic Botany 30: 103-142

Wongsa, P., Chaiwarit, J., and A. Zamaludien. 2012. In vitro screening of phenolic compounds, potential inhibition against alpha-amylase and alpha-glucosidase of culinary herbs in Thailand. Food Chemistry 131: 964-971. 


\section{CHAPTER V \\ DISSERTATION SUMMARY}

Summative Argument

Medicinal plant knowledge is a resource. Its historical value to the process of drug discovery has oft been presented (Dev 1983, Heinrich 2000, Fabricant and Farnsworth 2001, Oubre et al. 1997) and has underpinned many an argument for biodiversity conservation (Balick, et al. 1994, Bennett 1992, Plotkin 1988, Schultes 1994). Though both of these values are important applications of medicinal plant knowledge, they are not typically focused on benefitting the knowledge bearers.

Reyes-Garcia (2010) describes some of the varied benefits of researching

traditional [medicinal plant] knowledge systems, not the least of which is the recognition that these knowledge systems are holistic integrations of cultural knowledge, beliefs and practices that aid in understanding the functional value (efficacy) of a medicinal plant within its cultural context.

If the overarching query of this dissertation could be summarized, it would be: How do local medicinal plant selection strategies reflect culturally appropriate measures of safety or efficacy?

There are various reasons why a particular people group may use certain plants found in their environment and not others. Bennett and Husby (2007) suggest that these reasons may include: tradition, knowledge diffusion, availability, form-function relationship, taxonomic affiliation and efficacy. Most of these reasons for ongoing plant use may also be applied to the reasons for initial plant selection, and I have touched on a few of them in this dissertation. Though it would be naïve to ignore the use of trial and 
error in the medicinal plant selection process, I posit that processes of trial and error are most likely informed by prior historical knowledge/tradition, or guided by cultural/folk classification (e.g., form-function or organoleptic characteristics), or delimited by the chemical ecology of the available local plants (Andrade-Cetto 2010; Leonti et al. 2010).

The main pretext for this dissertation, therefore, has been the idea that the intrinsic value of a local pharmacopoeia is intricately tied to its plant selection strategies, which draw on ethnobotanical, ethnomedicinal and phytochemical elements (inter alia) to make an integrated whole. It is also my argument that the interdisciplinary approach is necessary to adequately identify plant-selection strategies and to achieve what Etkin (2001:6) specified as an important research objective of the field of Ethnopharmacology: "enriching the cultural interpretations of medical actions by exploring the physiologic potential of plants."

Chapter Summaries \& Risk-Benefit Analysis

The antidiabetic pharmacopoeia of Trinidad and Tobago is of recent derivation that is most likely the outcome of non-random trial and error. Three of the plantselection strategies that may have guided the trial and error process were elucidated in this dissertation and the order of importance appears to be: Historical/Cultural Knowledge, Folk Disease Concepts and Medicinal Use of Food Plants. The benefits and risks of each plant-selection strategy in addressing concerns of safety and efficacy are outlined below, along with potential challenges and opportunities. 


\section{Historical/Cultural Knowledge}

My findings in Chapters 2 and 3 indicated that the DM remedies most commonly cited in literature and field surveys were Paleotropical natives that are used in India or Africa and also across the Caribbean Basin. From the pre-2000 ethnobotanical studies, (Chapter 2) Momordica spp. were referenced in 3 Indian, 3 African and 17 Caribbean sources, Catharanthus roseus in 3 Indian, 2 African and 10 Caribbean sources and Azadirachta indica in 8 Indian and 2 Caribbean sources. In the T\&T field surveys and post-2000 literature (Chapter 3), these species had the most citations as well: Momordica charantia (23), Catharanthus roseus (15), and Azadirachta indica (15).

Benefits: One benefit associated with using plant species for which there is historical /cultural precedent is that, more often than not, these species have also been used as DM remedies in other areas of the world, where they have been subjected to preclinical and, in some cases, clinical trials that corroborated their antidiabetic/ hypoglycemic action (Ezuruike and Prieto 2014; Singh et al. 2012). Another benefit is that the means of safely preparing and administering these remedies are well established. In some cases, cultural use practices may also increase bioavailability, such as the effect of piperine from black pepper (Piper nigrum) on curcumin from turmeric (Curcuma longa) (Jurenka 2009), both of which are customarily consumed together in curries in Trinidad and Tobago. Knowledge of best practices for cultivation or preservation of these plant remedies would also likely be available to users.

Risks: In the absence of historical texts for verification, what is presumed to be the traditional use of a plant species may be a more recent adoption, as in the case of the use of garlic for cardiovascular concerns in Europe (Leonti et al. 2010). In such a 
scenario, the presumed safety of what is thought to be a centuries-old remedy is called into question. Relatedly, remedies that have a reputation of long-term use may be more likely to be used in a cavalier fashion, potentially resulting in adverse effects.

Historical/cultural uses of plants are often associated with rituals and superstitious beliefs. If current users do not share the belief system of their forebears, they may deliberately avoid using these remedies or may not use them according to the instructions given. In the latter case, there may be useful elements of preparation that are lost. For example, in Trinidad, the plant Leonotis nepetifolia is a popular cold/cough remedy (Clement et al. 2015), but unlike most remedies it is not prepared as a tea. Instead, users are told to pound (macerate) the freshly collected leaves, squeeze the liquid into a spoon, and swallow it with a pinch of salt, or follow it with a spoon of sweet oil (a.k.a. olive oil). Whether the outcome differs when the salt or oil is omitted is uncertain, but salt and sweet oil are associated with certain Shango (a syncretic Afro-Trinidadian cult/ religion) purifying/healing rituals (Simpson $1962 \mathrm{a} \& b$ ) and may be viewed with some suspicion.

Challenge: Except in the case of Ayurvedic remedies, most of the historical/ cultural knowledge of plant remedies in T\&T is orally transmitted. As the older generation passes off the scene, there is a risk of losing this knowledge, especially if the plant names and applications are in languages that are infrequently used. Additionally, as a society becomes more modernized or urbanized, there is less direct reliance on plants. Therefore less interest or value is placed on preserving the knowledge of the previous generation, even though current technologies would facilitate such record-keeping.

Opportunity: Recently, the review of different historical documents such as Rumphius' Ambonese herbal (Buenz et al. 2005), or Rolander's Diary from his time in 
Suriname (van Andel et al. 2012), have provided useful insights into the historical/ cultural plant use of a region that may corroborate existing patterns of use. In another instance, the review of an old Anglo-Saxon herbal uncovered a useful eye salve that is effective against methicillin-resistant Staphylococcus aureus (Harrison et al. 2015)

\section{$\underline{\text { Folk Disease Concepts }}$}

The ethno-medicinal analyses of T\&T's DM remedies (Chapter 3) showed the predominance of the hot/cold disease model among the antidiabetic remedies selected. Nevertheless, rather than being viewed as acting antagonistically, the other disease concepts/categories (clean/dirty, bitter/sweet, high blood pressure \& urinary concerns) seemed to be viewed as having additive effects. As such, Momordica charantia, which is considered to have cooling, cleansing and bitter properties continues to be the most cited DM remedy in T\&T and the Caribbean (Chapters 2 and 3). Also, the other four of the top five DM remedies of T\&T were all aligned to at least two of the five DM disease concepts/categories: Azadirachta indica (all five concepts), Catharanthus roseus (high blood pressure and urinary), Phyllanthus spp.(cooling, high blood pressure and urinary), and Bryophyllum pinnatum (cooling, cleansing, high blood pressure and urinary).

Benefits: Folk-disease concepts provide a systematized means of selecting remedies. Users may select from among available remedies by choosing the plant that is perceived to have the majority of the desirable properties to treat DM symptoms. Folk models also provide a mnemonic system that increases the accuracy of oral knowledge transmission and the likelihood of correct species selection (Bennett 2007). Lastly, folk disease models can provide clues to the physiological properties or phytochemical content of the plants that are responsible for their efficacy as a DM remedy. 
Risks: Currently in T\&T, the hot/cold folk disease concept may no longer be universally understood. Some participants who cited a plant as being used for cooling were not able to explain what a cooling was or why it was necessary. In cultures that employ it, the hot/cold disease concept is not based entirely on a physical sensation of temperature associated with the plant (Quinlan 2004; Garcia-Hernandez et al. 2015). A misunderstanding of this idea may result in the exclusive use of plants that act as fever reducers, few of which are among T\&Ts recorded cooling plants. A related risk is the associated reliance on organoleptic properties to infer potency or efficacy. Bitter-taste sensitivity may vary among individuals. If a strongly bitter taste is sought, it may be harmful, as some bitter plants contain alkaloids that are useful in small doses but harmful in larger doses (Harborne 1993). Finally, the clean/dirty blood disease model of DM involves the use of plants that act as purgatives or laxatives. As DM is a chronic ailment requiring daily treatment, frequent use of purgatives and laxatives may prove detrimental (Roerig et al. 2010).

Challenge: Folk models of disease are not static and are difficult to document precisely. As such, though some useful parallels exist between folk models and the biomedical mechanism of DM, they should not be equated.

Opportunity: Studies of folk disease models of DM have helped to highlight cultural taboos or uncover misapplied biomedical ideas that might undermine treatment guidelines. In Jamaica, the dietary guidelines given to diabetes patients are often flouted because extreme weight loss is socially stigmatized (Payne-Jackson 1999). In Ghana, produce that is grown using pesticides or fertilizers is avoided because it is seen as poor quality food that causes various chronic ailments, including diabetes (Aikins 2004). 


\section{Medicinal Use of Food Plants (Non-target Effects)}

The majority of the 99 recorded DM remedies of T\&T were medicinal/food plants that were already known or used as botanical remedies (Chapter 3). Of the 26 most cited DM remedies, 15 were already recorded pre-2000 as DM remedies in T\&T and 11 of them are plants used for food/flavoring. Considering these facts, it is understandable that $69 \%$ of the tested DM remedies (Chapter 4) contained phenolic compounds. This group of chemicals is valued for adding flavor, color and taste in foods. Phenolics are also associated with various health benefits, including antidiabetic activity. Using familiar food/ medicinal plants, increases the likelihood of discovering these non-target effects.

Benefits: By using known medicinal food plants, safety concerns are greatly reduced and cultural acceptance is improved. If incorporated as part of a dietary regime, rather than as herbal drugs, medicinal food plants may be beneficial for diabetics and also for individuals in at-risk groups for DM (Jenkins et al. 2003; Tuomilehto et al. 2001).

Risks: Using foods as medicine to treat DM presents the risk of hypoglycemia as a result of overconsumption. Users will need to be more vigilant about monitoring blood glucose levels, especially if conventional DM medications are also being used.

Challenge: Since a single meal is comprised of many food items, the process of discovering antidiabetic effects less systematic and may actually be difficult to confirm when foods have synergistic effects. Also, variation in food quality and preparation makes it unlikely that users will observe the same effect on different occasions.

Opportunity: The carbohydrate enzyme-inhibition property of food plants is fairly widespread and readily testable using simple bioassays such as those used in developing countries in the Screens-to-Nature (C) program (Andrae-Marobela et al 2010). 


\section{Study Limitations and Future Work}

My analysis of shared DM remedies in Chapter 2 was constrained by a lack of access to regional publications, especially from Africa. Additionally, though I used French and Spanish search terms that were similar to the terms used in English, those searches were not as exhaustive, as a result of limitations in my language skills. Future collaborations with persons having access to other historic sources from India, Africa or the Caribbean and who possess the requisite language skills to broaden my searches, will be a useful means of obtaining a more comprehensive picture of the origins and shared history of T\&T's antidiabetic pharmacopoeia.

In determining the predominant DM disease concept in T\&T (Chapter 3) a field survey that directly asked individuals about their knowledge of the folk disease concepts and the plants that are affiliated with them would be more definitive than mine. Such a survey should include a larger representative sample of the various demographic groups across T\&T to capture knowledge differences based on gender, ethnicity and locality.

My analysis of the enzyme inhibition activity and phenolic content of sixteen DM remedies of T\&T (Chapter 4) should be expanded to include as many of the ninety-nine DM remedies as possible. Where possible, fresh (not dried) plant material should be used, as this is typically the state in which participants described using DM remedies. The bacterial enzyme used for my assay should be replaced by plant or animal-based enzymes that are closer analogs to the digestive enzymes of the human gastrointestinal system. 


\section{LITERATURE CITED}

Aikins, A.D. 2004. Strengthening Quality and Continuity of Diabetes Care in Ghana : A Critical Social Psychological Approach. Journal of Health Psychology 9:295-309.

Andrade-Cetto, A. 2010. Mexican plants traditionally used for the treatment of type 2 diabetes. Pages 191-200 in M. Hiriart-Urdanivia, and J. Mas-Oliva, eds., Advances in Obesity-Diabetes Research at UNAM, Manual Moderno, Mexico.

Andrae-Marobela, K., Ntumy, A.N., Mokobela, M., Dube, M., Sosome, A., Muzila, M., Sethebe, B., Monyatsi, K.N., Ngwenya, B.N. 2012. " Now I Heal with Pride ”- The Application of Screens-to-Nature Technology to Indigenous Knowledge Systems Research in Botswana : Implications for Drug Discovery. Pages 239-264 in: K. Chibale, M. Davies-Coleman, and C. Masimirembwa, eds., Drug Discovery in Africa. SpringerVerlag Berlin, Heidelberg, Germany.

Balick, M.J., Arvigo, R., Romero, L. 1994. The Development of an Ethnobiomedical Forest Reserve in Belize : Its Role in the Preservation of Biological and Cultural Diversity. Conservation Biology 8:316-317.

Bennett, B.C. 1992. Plants and People of the Amazonian Rainforests: the role of Ethnobotany in Sustainable Development. BioScience 42:599-608.

Bennett, B.C., 2007. Doctrine of Signatures: An Explanation of Medicinal Plant Discovery or Dissemination of Knowledge? Economic Botany 61:246-255.

Bennett, B.C., Husby, C.E. 2008. Patterns of medicinal plant use: An examination of the Ecuadorian Shuar medicinal flora using contingency table and binomial analyses. Journal of Ethnopharmacology 116:422-430.

Buenz, E.J., Johnson, H.E., Beekman, E.M., Motley, T.J., Bauer, B.A. 2005.

Bioprospecting Rumphius's Ambonese Herbal: Journal of Ethnopharmacology 96: 5770 .

Clement, Y.N., Baksh-Comeau, Y.S., Seaforth, C.E. 2015. An ethnobotanical survey of medicinal plants in Trinidad. Journal of Ethnobiology and Ethnomedicine 11(1):1.

Dev, S. 1983. Natural products in medicine-present status and future prospects. Current Science 52:949-956.

Etkin, N.L. 2001. Perspectives in Ethnopharmacology: forging a closer link between bioscience and traditional empirical knowledge. Journal of Ethnopharmacology 76:177182. 
Ezuruike, U.F., Prieto, J.M. 2014. The use of plants in the traditional management of diabetes in Nigeria: Pharmacological and toxicological considerations. Journal of Ethnopharmacology 155:857-924.

Fabricant, D.S., and N. R. Farnsworth. 2001. The Value of Plants Used in Traditional Medicine for Drug Discovery. Environmental Health Perspectives 109:69-75.

García-Hernández, K.Y., Vibrans, H., Rivas-Guevara, M., and A. Aguilar-Contreras. 2015. This plant treats that illness? The hot-cold system and therapeutic procedures mediate medicinal plant use in San Miguel Tulancingo, Oaxaca, Mexico. Journal of Ethnopharmacology 163:12-30.

Harborne, J. 1993. Introduction to ecological biochemistry, 4th ed. Academic Press, London, UK.

Harrison, F., Roberts, A.E.L., Gabrilska, R., Rumbaugh, K.P., Lee, C., and S.P. Diggle. 2015. A 1000-year-old antimicrobial remedy with antistaphylococcal action. mBio 6:1-7.

Heinrich, M. 2000. Ethnobotany and its role in drug development. Phytotherapy Research 14:479-488.

Jenkins, D., Kendall, C., Marchie, A., Jenkins, A., Augustin, L., Ludwig, D., Barnard, N.D., and J. Anderson. 2003. Type 2 diabetes and the vegetarian diet. American Journal of Clinical Nutrition 78:610S-616S.

Jurenka, J.S. 2009. Anti-inflammatory properties of Curcumin, a major constituent of Curcuma longa: a review of preclinical and clinical research. Alternative Medicine Review 14:141-153.

Leonti, M., Cabras, S., Weckerle, C.S., Solinas, M.N., and L. Casu. 2010. The causal dependence of present plant knowledge on herbals-Contemporary medicinal plant use in Campania (Italy) compared to Matthioli (1568). Journal of Ethnopharmacology 130:379391.

Oubre, A.Y., Carlson, T.J., King, S.R., and G.M. Reaven. 1997. From plant to patient: an ethnomedicinal approach to the identification of new drugs for the treatment of NIMDD. Diabetologia 40:614-617.

Payne-Jackson, A. 1999. Biomedical and Folk Medical Concepts of Adult Onset Diabetes in Jamaica: Implications for Treatment. Health 3:5-46.

Plotkin, M.J. 1988. Conservation, Ethnobotany, and the Search for New Jungle Medicines: Pharmacognosy Comes of Age...Again. Pharmacotherapy: the Journal of Human Pharmacology and Drug Therapy 8:257-262.

Quinlan, M.B. 2004. From the bush: The front line of health care in a Caribbean village. Wadsworth Publishing Company. Belmont, CA. 
Reyes-García, V. 2010. The relevance of traditional knowledge systems for ethnopharmacological research: theoretical and methodological contributions. Journal of Ethnobiology and Ethnomedicine 6:32.

Roerig, J.L., Steffen, K.J., Mitchell, J.E., and C. Zunker. 2010. Laxative Abuse: Epidemiology, Diagnosis and Management. Therapy in Practice 70:1487-1503.

Schultes, R.E. 1994. The Importance of Ethnobotany in Environmental Conservation. American Journal of Economics and Sociology 53:202-206.

Simpson, G.E. 1962a. Folk Medicine in Trinidad. The Journal of American Folklore 75:326-340.

Simpson, G.E. 1962b. The Shango cult in Nigeria and in Trinidad. American Anthropologist 64:1204-1219.

Singh, U., Singh, S., and A. Kochhar. 2012. Therapeutic potential of antidiabetic nutraceuticals. Phytopharmacology 2:144-169.

Tuomilehto, J., Lindstrom, J., Eriksson, J.G., Valle, T.T., Hamalainen, H., IlanneParikka, P., Keinanen-Kiukaanniemi, S., Laasko, M., Louheranta, A., Rastas, M., Salminen, V., and M. Uusitupa, M. 2001. Prevention of Type 2 Diabetes Mellitus by Changes in Lifestyle Among Subjects With Impaired Glucose Tolerance. The New England Journal of Medicine 344:1343-1350.

van Andel, T., Maas, P., and J. Dobreff. 2012. Ethnobotanical notes from Daniel Rolander' s Diarium Surinamicum ( $1754-1756)$ : Are these plants still used in Suriname today? Taxon 61:852-863. 
APPENDICES 
APPENDIX I - A

List of Ethnobotanical Studies on Antidiabetics (1981 - 2000) (10 studies; 7 countries)

\begin{tabular}{|c|c|}
\hline $\begin{array}{l}\text { Country lor } \\
\text { Region }\end{array}$ & Reference \\
\hline Brazil & $\begin{array}{l}\text { Teixeira, C. C., Fuchs, F. D., Blotta, R. M., Da Costa, A. P., } \\
\text { Müssnich, D. G., and Ranquetat, G. G. (1992). Plants employed } \\
\text { in the treatment of diabetes mellitus: results of an ethno- } \\
\text { pharmacological survey in Porto Alegre, Brazil. Fitoterapia, } \\
\text { 63(4), 320-322. }\end{array}$ \\
\hline Guatemala & $\begin{array}{l}\text { Pöll, E. (1997). Medicinal plants of Guatemala with hypo- } \\
\text { glycemic effects. In II WOCMAP Congress Medicinal and } \\
\text { Aromatic Plants, Part 1: Biological Resources, Sustainable } \\
\text { Use, Conservation and Ethnobotany ISHS Acta Horticulturae }\end{array}$ \\
\hline Israel & $\begin{array}{l}\text { Yaniv, Z., Dafni, A., Friedman, J., and Palevitch, D. (1987). } \\
\text { Plants used for the treatment of diabetes in Israel. Journal of } \\
\text { Ethnopharmacology, 19(2), 145-151. }\end{array}$ \\
\hline Mexico & $\begin{array}{l}\text { Andrade-Cetto, A. (1995) Estudio Etnobotánico y Fitoquímico } \\
\text { de plantas útiles en la región de Xochipala Guerrero para el } \\
\text { tratamiento de la diabetes NID. Tesis de Maestría, Facultad de } \\
\text { Ciencias, UNAM, México. }\end{array}$ \\
\hline Mexico & $\begin{array}{l}\text { Alarcon-Aguilar, F.J., Roman-Ramos, R., Flores-Saenz, J.L. } \\
\text { (1993). Plantas medicinales usadas en el control de la diabetes } \\
\text { mellitus. Ciencia 44, 363-381. }\end{array}$ \\
\hline Mexico & $\begin{array}{l}\text { García H.M.C. (1981). Plantas medicinales utilizadas para la } \\
\text { diabetes en los mercados de Monterrey, N.L. México. Tesis de } \\
\text { Licenciatura, Facultad de Ciencias Biológicas, Universidad } \\
\text { Autónoma de Nuevo León, Monterrey, N.L. }\end{array}$ \\
\hline Morocco & $\begin{array}{l}\text { Ziyyat, A., Legssyer, A., Mekhfi, H., Dassouli, A., Serhrouchni, } \\
\text { M., Benjelloun, W. (1997) Phytotherapy of hypertension and } \\
\text { diabetes in oriental Morocco. Journal of Ethnopharmacology } \\
58(1): 45-54 .\end{array}$ \\
\hline Nigeria & $\begin{array}{l}\text { Famuyiwa, O. O. (1993). The efficacy of traditional medicine in } \\
\text { the management of diabetes mellitus in SW Nigeria. African } \\
\text { journal of medicine and medical sciences, 22(1), 31-37. }\end{array}$ \\
\hline $\begin{array}{l}\text { Trinidad and } \\
\text { Tobago }\end{array}$ & $\begin{array}{l}\text { Mahabir, D., and Gulliford, M. C. (1997). Use of medicinal } \\
\text { plants for diabetes in Trinidad and Tobago. Revista } \\
\text { Panamericana de Salud Pública, 1(3), 174-179. }\end{array}$ \\
\hline $\begin{array}{l}\text { United States } \\
\text { (Mexican } \\
\text { American) }\end{array}$ & $\begin{array}{l}\text { Hunt, L. M., Arar, N. H., and Akana, L. L. (2000). Herbs, } \\
\text { prayer, and insulin. Use of medical and alternative treatments } \\
\text { by a group of Mexican American diabetes patients. J Fam } \\
\text { Pract, } 49(3), 216-223 \text {. }\end{array}$ \\
\hline
\end{tabular}




\section{APPENDIX I - B}

List of Ethnobotanical Studies on Antidiabetics (2001 - 2015) (60 studies; 24 countries)

\begin{tabular}{|c|c|}
\hline $\begin{array}{l}\text { Country or } \\
\text { Region }\end{array}$ & Reference \\
\hline Algeria & $\begin{array}{l}\text { Rachid, A., Rabah, D., Farid, L., Zohra, S. F., Houcine, B., } \\
\text { and Nacéra, B. (2012). Ethnopharmacological survey of } \\
\text { medicinal plants used in the traditional treatment of diabetes } \\
\text { mellitus in NW and SW Algeria. Journal of Medicinal } \\
\text { Plants Research,6 (10), 2041-2050 }\end{array}$ \\
\hline Bangladesh & $\begin{array}{l}\text { Kadir, M. F., Sayeed, M. S. B., Shams, T., and Mia, M. M. } \\
\text { K. (2012). Ethnobotanical survey of medicinal plants used } \\
\text { by Bangladeshi traditional health practitioners in the } \\
\text { management of diabetes mellitus. Journal of } \\
\text { Ethnopharmacology, 144(3), 605-611. }\end{array}$ \\
\hline Bangladesh & $\begin{array}{l}\text { Ocvirk, S., Kistler, M., Khan, S., Talukder, S. H., and } \\
\text { Hauner, H. (2013). Traditional medicinal plants used for the } \\
\text { treatment of diabetes in rural and urban areas of Dhaka, } \\
\text { Bangladesh--an ethnobotanical survey. Journal of } \\
\text { Ethnobiology and Ethnomedicine, } 9,43 \text {. }\end{array}$ \\
\hline Bangladesh & $\begin{array}{l}\text { Rahman, M., Mishuk, A., Halder, S., and Rouf, A. S. S. } \\
\text { (2014). A Survey on Traditional Medicinal Plants used for } \\
\text { the Treatment of Diabetes in Urban Areas of Dhaka and } \\
\text { Khulna, Bangladesh. Global Journal of Medical } \\
\text { Research, 13(6). }\end{array}$ \\
\hline Bangladesh & $\begin{array}{l}\text { Rahmatullah, M., Azam, N. K., Khatun, Z., Seraj, S., Islam, } \\
\text { F., Rahman, M. A., Jahan, S., and Aziz, M.S. (2012). } \\
\text { Medicinal plants used for treatment of diabetes by the } \\
\text { Marakh sect of the Garo tribe living in Mymensingh district, } \\
\text { Bangladesh. African Journal of Traditional, } \\
\text { Complementary and Alternative Medicines, } 9(3), 380-385 .\end{array}$ \\
\hline Benin & $\begin{array}{l}\text { Fah L., Klotoé J.R., Dougnon V., Koudokpon H., Fanou } \\
\text { V.B.A., Dandjesso C., Loko F : (2013). Étude } \\
\text { ethnobotanique des plantes utilisées dans le traitement du } \\
\text { diabète chez les femmes enceintes à Cotonou et Abomey- } \\
\text { Calavi (Bénin). Journal of Animal and Plant Sciences. } 18 \\
\text { (1): } 2647-2658\end{array}$ \\
\hline Benin & $\begin{array}{l}\text { Laleye, F. O. A., Mensah, S., Assogbadjo, A. E., and } \\
\text { Ahissou, H. (2015). Diversity, Knowledge, and Use of } \\
\text { Plants in Traditional Treatment of Diabetes in the Republic } \\
\text { of Benin. Ethnobotany Research and Applications, 14, 231- } \\
257 .\end{array}$ \\
\hline
\end{tabular}


APPENDIX I - B - (continued)

\begin{tabular}{|c|c|}
\hline $\begin{array}{l}\text { Country or } \\
\text { Region }\end{array}$ & Reference \\
\hline Benin & $\begin{array}{l}\text { Lawin, I. F., Lalèyè, F. O. A., Agbani, O. P., and } \\
\text { Assogbadjo, A. E. (2015). Ethnobotanical assessment of the } \\
\text { plant species used in the treatment of diabetes in the } \\
\text { Sudano-Guinean zone of Benin. Journal of Animal \&Plant } \\
\text { Sciences, 26(3), 4108-4123. }\end{array}$ \\
\hline Cameroon & $\begin{array}{l}\text { Koyeu, T. E., Mendi, G., Tchamago, F. X., Tajeukem, V. } \\
\text { C., Franklin, V., and Linda, C. (2014). Ethnobotanic } \\
\text { Contribution of Cameroon: Anti-Diabetic Plants Inventory } \\
\text { in the Nkoung-Khi Division West Region Cameroon. } \\
\text { Applied Science Reports, } 8 \text { (3), 125-133 }\end{array}$ \\
\hline Canada (Cree & Leduc, C., Coonishish, J., Haddad, P., Cuerrier, A. (2006) \\
\hline Nation, Quebec) & $\begin{array}{l}\text { Plants used by the Cree Nations of Eeyou Istchee for the } \\
\text { treatment of diabetes: A novel approach in quantitative } \\
\text { ethnobotany. Journal of Ethnopharmacology, 105, 55-63. }\end{array}$ \\
\hline $\begin{array}{l}\text { Central African } \\
\text { Republic }\end{array}$ & $\begin{array}{l}\text { Apema R, Mozouloua D, Abeye J, Salamate F. M. L. } \\
\text { (2012). Les plantes médicinales utilisées dans le traitement } \\
\text { du diabète par les tradipraticiens à Bangui. Pharmacopée et } \\
\text { médecine traditionnelle africaines, } 16: 121-129\end{array}$ \\
\hline Cote d' Ivoire & $\begin{array}{l}\text { N'guessan, K., Kouassi, K. E., and Kouadio, K. (2009). } \\
\text { Ethnobotanical study of plants used to treat diabetes in } \\
\text { Traditional Medicine, by Abbey and Krobou People of } \\
\text { Agboville. American Journal of Scientific Research, 4, 45- } \\
58 .\end{array}$ \\
\hline Cuba & $\begin{array}{l}\text { García-Lazo, G., Lauzant-Diaz, E., Díaz Batista, A., and } \\
\text { Garcia-Mesa, M. (2015). Plantas consideradas útiles como } \\
\text { hipoglicemiantes, antihipertensivas o hipolipemiantes por } \\
\text { pacientes con enfermedades vasculares periféricas. Revista } \\
\text { Cubana de Plantas Medicinales, 20(1), 38-47. }\end{array}$ \\
\hline $\begin{array}{l}\text { Democratic } \\
\text { Republic of } \\
\text { Congo }\end{array}$ & $\begin{array}{l}\text { Kasali, M.F., Mahano, A.O., Bwironde, F.M., Amani, A.C., } \\
\text { Mangambu, J.D., Nyakabwa, D.S., Wimba, L., Tshibangu } \\
\text { D., Ngbolua, K., Kambale, J.K., and Mpiana, P.T. (2013). } \\
\text { Ethnopharmacological survey of plants used against } \\
\text { diabetes in Bukavu city (DR Congo). The Journal of } \\
\text { Ethnobiology and Traditional Medicine. 119, 538-546. }\end{array}$ \\
\hline $\begin{array}{l}\text { Democratic } \\
\text { Republic of } \\
\text { Congo }\end{array}$ & $\begin{array}{l}\text { Katemo, M., Mpiana, P.T., Mbala, B.M., Mihigo, S.O., } \\
\text { Ngbolua, K N., Tshibangu, D.S.T., and Koyange, P.R. } \\
\text { (2012). Ethnopharmacological survey of plants used against } \\
\text { diabetes in Kisangani city (DR Congo). Journal of } \\
\text { Ethnopharmacology, 144(1), 39-43. }\end{array}$ \\
\hline
\end{tabular}


APPENDIX I - B - (continued)

\begin{tabular}{|ll|}
\hline $\begin{array}{l}\text { Country or } \\
\text { Region }\end{array}$ & Reference \\
\hline Eritrea & $\begin{array}{l}\text { Demoz, M.S., Gachoki, K.P., Mungai, K J., and Negusse, } \\
\text { B.G. (2015). Ethnobotanical survey and preliminary } \\
\text { phytochemical studies of plants traditionally used for } \\
\text { diabetes in Eritrea. European Journal of Medicinal } \\
\text { Plants, 9(2). }\end{array}$ \\
\hline Baldé, N., Youlaa, A., Baldé, M.D., Kakéa, A., Dialloa, \\
M.M., Baldé, M.A., Maugendred, D. (2006). Herbal \\
medicine and treatment of diabetes in Africa: an example \\
from Guinea. Diabetes \& Metabolism 32, 171-175.
\end{tabular}


APPENDIX I - B - (continued)

\begin{tabular}{|c|c|}
\hline $\begin{array}{l}\text { Country or } \\
\text { Region }\end{array}$ & Reference \\
\hline India (Kerala) & $\begin{array}{l}\text { Jayakumar, G., Ajithabai, M.D., Sreedevi, S., Viswanathan, } \\
\text { P.K., and Remeshkumar, B. (2010). Ethnobotanical survey } \\
\text { of plants used to treat diabetes. Indian Journal of } \\
\text { Traditional Knowledge, } 9(1), 100-104 .\end{array}$ \\
\hline $\begin{array}{l}\text { India (Madhya } \\
\text { Pradesh) }\end{array}$ & $\begin{array}{l}\text { Yadav, M., Khan, K. K., and Beg, M. Z. (2012). Medicinal } \\
\text { Plants Used For The Treatment Of Diabetes By The Baiga } \\
\text { Tribe Living In Rewa District MP. Indian Journal of Life } \\
\text { Science, 2(1), 99-102. }\end{array}$ \\
\hline $\begin{array}{l}\text { India } \\
\text { (Tamilnadu) }\end{array}$ & $\begin{array}{l}\text { Elavarasi, S., and Saravanan, K. (2012). Ethnobotanical } \\
\text { study of plants used to treat diabetes by tribal people of } \\
\text { Kolli Hills, Namakkal District, Tamilnadu, India. } \\
\text { International Journal of PharmTech Research, (4), 404-411. }\end{array}$ \\
\hline $\begin{array}{l}\text { India } \\
\text { (Tamilnadu) }\end{array}$ & $\begin{array}{l}\text { Shanmugam, S., Manikandan, K., and Rajendran, K. (2009). } \\
\text { Ethnomedicinal survey of medicinal plants used for the } \\
\text { treatment of diabetes and jaundice among the villagers of } \\
\text { Sivagangai District, Tamilnadu. Ethnobotanical } \\
\text { Leaflets, (1), 22. }\end{array}$ \\
\hline $\begin{array}{l}\text { India } \\
\text { (Tamilnadu) }\end{array}$ & $\begin{array}{l}\text { Vijayalakshmi, N., Anbazhagan, M., and Arumugam, K. } \\
\text { (2014). Medicinal plants for Diabetes used by the people of } \\
\text { Thirumoorthy hills region of Western Ghats, Tamilnadu, } \\
\text { India. International Journal of Current Microbiology and } \\
\text { Applied Sciences, 3(7), 405-410. }\end{array}$ \\
\hline $\begin{array}{l}\text { India } \\
\text { (Uttarakhand) }\end{array}$ & $\begin{array}{l}\text { Paliwal, A. K., and Joshi, R. (2007). Medicinal plants used } \\
\text { for treatment of diabetes (madhu-meha) from Bageshwar } \\
\text { District of Uttarakhand. Plant Archives, 7(2), 855-857. }\end{array}$ \\
\hline $\begin{array}{l}\text { India (West } \\
\text { Bengal) }\end{array}$ & $\begin{array}{l}\text { Ghosh, A. (2006). Medicinal plants used for treatment of } \\
\text { diabetes by the tribals of Bankura, Purulia and Medinipur of } \\
\text { West Bengal. Journal of Economic and Taxononomic } \\
\text { Botany, 30, 233-238. }\end{array}$ \\
\hline Iran & $\begin{array}{l}\text { Bahmani, M., Zargaran, A., Rafieian-Kopaei, M., and Saki, } \\
\text { K. (2014). Ethnobotanical study of medicinal plants used in } \\
\text { the management of diabetes mellitus in the Urmia, NW } \\
\text { Iran. Asian Pacific journal of tropical medicine 7, S348- } \\
\text { S354. }\end{array}$ \\
\hline Iran & $\begin{array}{l}\text { Shokrzadeh, M., Ebadi, A. G., and Babaee, M. (2005, } \\
\text { August). Ethnobotanical and ethnopharmacology survey of } \\
\text { medicinal plants used in the treatment of diabetes in } \\
\text { Mazandaran province (Iran), Fourth Intl. In Congress of } \\
\text { Ethnobotany (pp. 21-26). }\end{array}$ \\
\hline
\end{tabular}


APPENDIX I - B - (continued)

\begin{tabular}{|c|c|}
\hline $\begin{array}{l}\text { Country or } \\
\text { Region }\end{array}$ & Reference \\
\hline Kenya & $\begin{array}{l}\text { Keter, L. K., and Mutiso, P. C. (2012). Ethnobotanical } \\
\text { studies of medicinal plants used by Traditional Health } \\
\text { Practitioners in the management of diabetes in Lower } \\
\text { Eastern Province, Kenya. Journal of Ethnopharmacology, } \\
\text { 139(1), 74-80. }\end{array}$ \\
\hline Mauritius & $\begin{array}{l}\text { Mootoosamy, A., and Mahomoodally, M. F. (2014). } \\
\text { Ethnomedicinal application of native remedies for diabetes } \\
\text { and related complications in Mauritius. Journal of } \\
\text { Ethnopharmacology, 151(1), 413-444. }\end{array}$ \\
\hline Mexico & $\begin{array}{l}\text { Alarcón-Aguilar, F. J., Hernández-Galicia, E., and Román- } \\
\text { Ramos, R. (2008). Diabetes mellitus y plantas medicinales } \\
\text { en México. Anuario de investigación en etnomedicina, } \\
\text { medicinas complementarias y utilización de plantas } \\
\text { medicinales. UNAM-Iztapalapa, 27-39. }\end{array}$ \\
\hline Mexico & $\begin{array}{l}\text { Nora, A. J. E. (2002). Plantas medicinales usadas por } \\
\text { ancianos con diabetes en la ciudad de Mexico, Distrito } \\
\text { Federal. Vivere e" curare" La vecchiaia nel mondo, } 3,155 .\end{array}$ \\
\hline Mexico & $\begin{array}{l}\text { Romero-Cerecero, O., Reyes-Morales, H., Aguilar-Santa } \\
\text { María, L., Huerta-Reyes, M., and Tortoriello-Garcia, J. } \\
\text { (2009). Use of medicinal plants among patients with } \\
\text { diabetes mellitus type } 2 \text { in Morelos, Mexico. Boletín Latino- } \\
\text { americano y del Caribe de Plantas Medicinales y } \\
\text { Aromáticas, } 8 \text { (5), 380-388. }\end{array}$ \\
\hline Morocco & $\begin{array}{l}\text { Eddouks, M., Ouahidi, M. L., Farid, O., Moufid, A., } \\
\text { Khalidi, A., and Lemhadri, A. (2007). The use of medicinal } \\
\text { plants in the treatment of diabetes in Morocco. } \\
\text { Phytotherapie, 5, 194-203. }\end{array}$ \\
\hline Morocco & $\begin{array}{l}\text { Jouad, H., Haloui, M., Rhiouani, H., El Hilaly, J., and } \\
\text { Eddouks, M. (2001). Ethnobotanical survey of medicinal } \\
\text { plants used to treat diabetes, cardiac and renal diseases in } \\
\text { the North centre region of Morocco (Fez-Boulemane) } \\
\text { Journal of Ethnopharmacology, } 77(2), 175-182 .\end{array}$ \\
\hline Morocco & $\begin{array}{l}\text { Tahraoui, A., El-Hilaly, J., Israili, Z. H. and Lyoussi, B. } \\
\text { (2007). Ethnopharmacological survey of plants used in the } \\
\text { traditional treatment of hypertension and diabetes in south- } \\
\text { eastern Morocco (Errachidia province). Journal of } \\
\text { Ethnopharmacology, 110, 105-117 }\end{array}$ \\
\hline Morocco & $\begin{array}{l}\text { Ghourri, M., and Douira, L. Z. A. (2013). Usage des plantes } \\
\text { médicinales dans le traitement du Diabète Au Sahara } \\
\text { marocain (Tan-Tan). Journal of Animal \& Plant } \\
\text { Sciences, 17(1), 2388-2411. }\end{array}$ \\
\hline
\end{tabular}


APPENDIX I - B - (continued)

\begin{tabular}{|c|c|}
\hline $\begin{array}{l}\text { Country or } \\
\text { Region }\end{array}$ & Reference \\
\hline Nepal & $\begin{array}{l}\text { Joshi, K. (2011). Ethnobotanical study of plants used for the } \\
\text { treatment of diabetes mellitus in the mountainous regions of } \\
\text { Nepal. Journal of Non-timber Forest Products, 18(1), 19- } \\
26 \text {. }\end{array}$ \\
\hline Nigeria & $\begin{array}{l}\text { Abo, K. A., Fred-Jaiyesimi, A. A., and Jaiyesimi, A.E.A. } \\
\text { (2008). Ethno-botanical studies of medicinal plants used in } \\
\text { the management of diabetes mellitus in SW Nigeria. Journal } \\
\text { of Ethnopharmacology, 115(1), 67-71. }\end{array}$ \\
\hline Nigeria & $\begin{array}{l}\text { Etuk, E. U., Bello, S. O., Isezuo, S. A., and Mohammed, B. } \\
\text { J. (2010). Ethnobotanical survey of medicinal plants used } \\
\text { for the treatment of Diabetes mellitus in the north western } \\
\text { region of Nigeria. Asian Journal of Experimental Biological } \\
\text { Sciences, } 1(1), 55-59 \text {. }\end{array}$ \\
\hline Nigeria & $\begin{array}{l}\text { Kadiri, M. (2015). Ethnobotanical survey of plants used in } \\
\text { the management of diabetes mellitus in Abeokuta, Nigeria. } \\
\text { Journal of Drug Delivery \& Therapeutics, 5(3), 13-23. }\end{array}$ \\
\hline Nigeria & $\begin{array}{l}\text { Makinde, S. C. O., Ojekale, A. B., Oshinaike, T. S., and } \\
\text { Awusinu, T. S. (2015). An Ethnomedical and } \\
\text { Ethnobotanical survey of Plants Herbal Therapy used for } \\
\text { Obesity, Asthma, Diabetes and Fertility by the Badagry } \\
\text { people of Lagos State, Nigeria. Journal of Medicinal } \\
\text { Plants, 3(5), 01-06. }\end{array}$ \\
\hline Nigeria & $\begin{array}{l}\text { Onakpa, M. M., and Owoleke, O. E. (2010). A Survey of } \\
\text { medicinal plants used in the management of Diabetes } \\
\text { Mellitus in Northcentral Nigeria. Biological and } \\
\text { Environmental Sciences Journal for the Tropics, 7(4), 124- } \\
127 .\end{array}$ \\
\hline Pakistan & $\begin{array}{l}\text { Ahmad, M., Qureshi, R., Arshad, M., Khan, M.A., and } \\
\text { Zafar, M. (2009). Traditional herbal remedies used to treat } \\
\text { diabetes from district Attock (Pakistan). Pakistan Journal of } \\
\text { Botany, 41(6), 2777-2782. }\end{array}$ \\
\hline Pakistan & $\begin{array}{l}\text { Yaseen, G., Ahmad, M., Zafar, M., Sultana, S., Kayani, S., } \\
\text { Cetto, A. A., and Shaheen, S. (2015). Traditional } \\
\text { management of diabetes in Pakistan: Ethnobotanical } \\
\text { investigation from Traditional Health Practitioners. Journal } \\
\text { of Ethnopharmacology, 174, 91-117. }\end{array}$ \\
\hline Senegal & $\begin{array}{l}\text { Dièye, A.M., Sarr, A., Diop, S.N., Ndiaye, M., Sy, G.Y., } \\
\text { Diarra, M., and Faye, B. (2008). Medicinal plants and the } \\
\text { treatment of diabetes in Senegal: survey with patients. } \\
\text { Fundamental \& Clinical Pharmacologv, 22(2). 211-216. }\end{array}$ \\
\hline
\end{tabular}


APPENDIX I - B - (continued)

\begin{tabular}{|c|c|}
\hline $\begin{array}{l}\text { Country or } \\
\text { Region }\end{array}$ & Reference \\
\hline South Africa & $\begin{array}{l}\text { Chauke, M. A., Shai, L. J., and Mogale, M. A. (2013). } \\
\text { Ethnobotanical study on medicinal plant material used to } \\
\text { treat and manage diabetes mellitus and other diseases in } \\
\text { Phalaborwa (South Africa). South African Journal of } \\
\text { Botany, (86), 145. }\end{array}$ \\
\hline South Africa & $\begin{array}{l}\text { Erasto, P., Adebola, P. O., Grierson, D. S., and Afolayan, A. } \\
\text { J. (2005). An ethnobotanical study of plants used to treat } \\
\text { diabetes in the Eastern Cape Province, South Africa. African } \\
\text { Journal of Biotechnology, } 4(12) \text {. }\end{array}$ \\
\hline South Africa & $\begin{array}{l}\text { Oyedemi, S.O., Bradley, G., and Afolayan, A.J. (2009) } \\
\text { Ethnobotanical survey of medicinal plants used for the } \\
\text { management of diabetes mellitus in the Nkonkobe } \\
\text { Municipality of South Africa. Journal of Medicinal Plants } \\
\text { Research, 3(12), 1040-1044. }\end{array}$ \\
\hline South Africa & $\begin{array}{l}\text { Semenya, S., Potgieter, M., and Erasmus, L. (2012). } \\
\text { Ethnobotanical survey of medicinal plants used by Bapedi } \\
\text { healers to treat diabetes mellitus in the Limpopo Province, } \\
\text { South Africa. Journal of Ethnopharmacology, } 141(1), 440- \\
5 .\end{array}$ \\
\hline Togo & $\begin{array}{l}\text { Holaly, G. E., Simplice, K. D., Charlemagne, G., Kodjovi, } \\
\text { A., Kokou, A., Tchadjobo, T., Amegnona, A., Komlan, B., } \\
\text { and Jacques, S. (2015). Étude ethnobotanique des plantes } \\
\text { utilisées dans le traitement du diabète dans la médecine } \\
\text { traditionnelle de la région Maritime du Togo. The Pan } \\
\text { African medical journal, 20, 437-437. }\end{array}$ \\
\hline Togo & $\begin{array}{l}\text { Karou, S. D., Tchacondo, T., Djikpo Tchibozo, M. A., } \\
\text { Abdoul-Rahaman, S., Anani, K., Koudouvo, K.,Batawila, } \\
\text { K., Agbonon, A., Simpore, J., and de Souza, C. (2011). } \\
\text { Ethnobotanical study of medicinal plants used in the } \\
\text { management of diabetes mellitus and hypertension in the } \\
\text { Central Region of Togo. Pharmaceutical Biology, 49(12), } \\
\text { 1286-1297. }\end{array}$ \\
\hline Turkey & $\begin{array}{l}\text { Durmusskahya, C., and Öztürk, M. (2013). Ethnobotanical } \\
\text { survey of medicinal plants used for the treatment of diabetes } \\
\text { in Manisa, Turkey. Sains Malaysiana, } 42(10), 1431-1438 .\end{array}$ \\
\hline
\end{tabular}




\section{APPENDIX II}

Demographic Characteristics of study participants (A) Community participants; (B) Herbalist participants

\begin{tabular}{|c|c|}
\hline \multicolumn{2}{|c|}{ COMMUNITY } \\
\hline Demographic & \# Persons \\
\hline Descriptor & (Percentage) \\
\hline \multicolumn{2}{|l|}{ Gender } \\
\hline Male & $28(35 \%)$ \\
\hline Female & $52(65 \%)$ \\
\hline \multicolumn{2}{|l|}{ Age Range } \\
\hline Over 65 & $31(39 \%)$ \\
\hline $41-65$ & $41(51 \%)$ \\
\hline $26-40$ & $8(10 \%)$ \\
\hline \multicolumn{2}{|l|}{ Ethnicity } \\
\hline African & $46(58 \%)$ \\
\hline Indian & $12(15 \%)$ \\
\hline Mixed & $22(27 \%)$ \\
\hline \multicolumn{2}{|c|}{$\begin{array}{l}\text { Education } \\
\text { (Highest Level) }\end{array}$} \\
\hline Primary & $45(56 \%)$ \\
\hline Secondary & $17(21 \%)$ \\
\hline Tertiary & $13(16 \%)$ \\
\hline Technical & $2(3 \%)$ \\
\hline None & $3(4 \%)$ \\
\hline \multicolumn{2}{|c|}{$\begin{array}{l}\text { Locality } \\
\text { (Current Residence) }\end{array}$} \\
\hline Rural & $34(43 \%)$ \\
\hline Suburban & $40(50 \%)$ \\
\hline Urban & $6(7 \%)$ \\
\hline
\end{tabular}

\begin{tabular}{|c|c|}
\hline \multicolumn{2}{|c|}{ HERBALISTS } \\
\hline Demographic & \# Persons \\
\hline Descriptor & (Percentage) \\
\hline \multicolumn{2}{|l|}{ Gender } \\
\hline Male & $21(66 \%)$ \\
\hline Female & $9(34 \%)$ \\
\hline \multicolumn{2}{|l|}{ Age Range } \\
\hline Over 65 & $4(13 \%)$ \\
\hline $41-65$ & $23(71 \%)$ \\
\hline $26-40$ & $4(13 \%)$ \\
\hline Not stated & $1(3 \%)$ \\
\hline \multicolumn{2}{|l|}{ Ethnicity } \\
\hline African & $16(50 \%)$ \\
\hline Indian & $5(16 \%)$ \\
\hline Mixed & $7(22 \%)$ \\
\hline White & $2(6 \%)$ \\
\hline Other & $2(6 \%)$ \\
\hline \multirow{2}{*}{\multicolumn{2}{|c|}{$\begin{array}{l}\text { Education } \\
\text { (Highest Level) }\end{array}$}} \\
\hline & \\
\hline Primary & $3(9 \%)$ \\
\hline Secondary & $11(35 \%)$ \\
\hline Tertiary & $14(44 \%)$ \\
\hline Technical & $3(9 \%)$ \\
\hline Not stated & $1(3 \%)$ \\
\hline \multirow{2}{*}{\multicolumn{2}{|c|}{$\begin{array}{l}\text { Locality } \\
\text { (Current Residence) }\end{array}$}} \\
\hline & \\
\hline Rural & $12(37 \%)$ \\
\hline Suburban & $13(41 \%)$ \\
\hline Urban & $3(9 \%)$ \\
\hline Not Stated & $4(13 \%)$ \\
\hline
\end{tabular}


APPENDIX III -A - List of 48 plants cited in pre-2000 literature as antidiabetic remedies in T\&T

\begin{tabular}{|c|c|c|c|c|c|}
\hline Scientific Name & Family Name $^{1}$ & Local Name(s) & Plant Part & Native Range $^{2}$ & Sources Cited \\
\hline Abrus precatorius $\mathrm{L}$. & Fabaceae & $\begin{array}{l}\text { crab eye/ licorice/ } \\
\text { jumbie bead }\end{array}$ & aerial parts & Paleotropical & $\mathrm{e}$ \\
\hline Ageratum conyzoides $(\mathrm{L}.) \mathrm{L}$. & Asteraceae & zeb-a-fam & root & Neotropical & $\mathrm{g}$ \\
\hline Aloe vera (L.) Burm. f. & Xanthorrhoeaceae & aloes & not specified & Paleo-Temperate & $\mathrm{c}$ \\
\hline Annona muricata $\mathrm{L}$. & Annonaceae & soursop & not specified & Neotropical & $\mathrm{c}$ \\
\hline Antigonon leptopus Hook. \& Arn. & Polygonaceae & coralita & vine & Neotropical & $\mathrm{a}$ \\
\hline Aristolochia rugosa Lam. & Aristolochiaceae & matroot & whole plant & Neotropical & $\mathrm{d}$ \\
\hline Aristolochia trilobata $\mathrm{L}$. & Aristolochiaceae & twef or tref & leaf decoctions & Neotropical & $\mathrm{g}$ \\
\hline $\begin{array}{l}\text { Artocarpus altilis (Parkinson ex } \\
\text { F.A.Zorn) Fosberg }\end{array}$ & Moraceae & breadfruit & yellowing leaf & Paleotropical & $\mathrm{d}, \mathrm{f}, \mathrm{g}$ \\
\hline Azadirachta indica A. Juss & Meliaceae & neem/nim or neeb & leaves & Paleotropical & $\mathrm{b}$ \\
\hline Bidens pilosa $\mathrm{L}$. & Asteraceae & $\begin{array}{l}\text { needle grass/ } \\
\text { railway daisy }\end{array}$ & leaves & Neotropical & $\mathrm{a}, \mathrm{d}$ \\
\hline Bixa orellana $\mathrm{L}$. & Bixaceae & roucou/ruku & leaves, root & Neotropical & $\mathrm{a}, \mathrm{d}, \mathrm{g}$ \\
\hline Bontia daphnoides $\mathrm{L}$. & Scrophulariaceae & olive bush & leaves & Neotropical & $\mathrm{a}, \mathrm{c}, \mathrm{d}$ \\
\hline
\end{tabular}


APPENDIX III-A (continued)

\begin{tabular}{|c|c|c|c|c|c|}
\hline Scientific Name & Family Name $^{1}$ & Local Name(s) & Plant Part & Native Range $^{2}$ & Sources Cited \\
\hline Cajanus cajan (L.) Millsp. & Fabaceae & pigeon peas & $\begin{array}{l}\text { leaves and } \\
\text { stems }\end{array}$ & Paleotropical & $\mathrm{e}$ \\
\hline Cannabis sativa $\mathrm{L}$. & Cannabaceae & ganja/marijuana & $\begin{array}{l}\text { leaves, shoots, } \\
\text { seeds }\end{array}$ & Paleo-Temperate & $\mathrm{b}$ \\
\hline Carica papaya $\mathrm{L}$. & Caricaceae & paw-paw & green fruit & Neotropical & $\mathrm{a}$ \\
\hline Catharanthus roseus (L.) G. Don & Apocynaceae & periwinkle & $\begin{array}{l}\text { whole herb } \\
\text { (leaves, flowers } \\
\text { \& roots) }\end{array}$ & Paleotropical & $\mathrm{a}, \mathrm{d}, \mathrm{g}$ \\
\hline $\begin{array}{l}\text { Chromolaena odorata (L.) R.M. } \\
\text { King \& H. Rob. }\end{array}$ & Asteraceae & christmas bush & flowers & Neotropical & $\mathrm{g}$ \\
\hline Cissampelos pareira L. & Menispermaceae & pataçon & root & Neotropical & $\mathrm{g}$ \\
\hline Citrus $\mathrm{x}$ aurantium $\mathrm{L}$. & Rutaceae & sour orange & fruit peel & Paleo-Temperate & $\mathrm{c}$ \\
\hline Coccinia grandis (L.) Voigt. & Cucurbitaceae & $\begin{array}{l}\text { parwar/ wild } \\
\text { cucumber/ ivy } \\
\text { gourd }\end{array}$ & leaf juice & Paleotropical & $\mathrm{b}$ \\
\hline Cocos nucifera $\mathrm{L}$. & Arecaceae & coconut & shell, flower & Paleotropical & $\mathrm{a}$ \\
\hline $\begin{array}{l}\text { Cola nitida (Vent.) Schott \& } \\
\text { Endl. }\end{array}$ & Malvaceae & obie seed & seed & Paleotropical & $\mathrm{f}$ \\
\hline
\end{tabular}


APPENDIX III-A (continued)

\begin{tabular}{|c|c|c|c|c|c|}
\hline Scientific Name & Family Name $^{1}$ & Local Name(s) & Plant Part & Native Range $^{2}$ & Sources Cited \\
\hline $\begin{array}{l}\text { Colubrina arborescens (Mill.) } \\
\text { Sarg. }\end{array}$ & Rhamnaceae & mauby & bark & Neotropical & $\mathrm{d}$ \\
\hline $\begin{array}{l}\text { Cordia curassavica (Jacq.) Roem. } \\
\quad \text { \& Schult. }\end{array}$ & Boraginaceae & black sage & not specified & Neotropical & $\mathrm{c}$ \\
\hline Cymbopogon citratus (DC.) Stapf & Poaceae & fever grass & not specified & Paleotropical & $\mathrm{c}$ \\
\hline Eryngium foetidum $\mathrm{L}$. & Apiaceae & $\begin{array}{l}\text { bandhaniya/ fit } \\
\text { weed/shado beni }\end{array}$ & leaves, roots & Neotropical & $\mathrm{b}, \mathrm{g}$ \\
\hline Gomphrena globosa L. & Amaranthaceae & bachelor button & leaves & Neotropical & $\mathrm{a}, \mathrm{g}$ \\
\hline Ipomoea aquatica Forssk. & Convolvulaceae & kharmi bhaji & $\begin{array}{l}\text { leaves \& tender } \\
\text { stems }\end{array}$ & Paleotropical & $\mathrm{b}$ \\
\hline Laportea aestuans (L.) Chew & Urticaceae & stinging nettle & leaves & Pantropical & $\mathrm{a}$ \\
\hline Leonotis nepetifolia (L.) R. Br. & Lamiaceae & shandilay & not specified & Paleotropical & $\mathrm{c}$ \\
\hline Momordica charantia L. & Cucurbitaceae & coraillee/ caraaili & leaves, fruit & Paleotropical & $a, b, c, e, f, g$ \\
\hline Moringa oleifera Lam. & Moringaceae & saijan & leaves & Paleotropical & $\mathrm{b}$ \\
\hline Morus alba L. & Moraceae & pawi bush & not specified & Paleo-Temperate & $\mathrm{a}$ \\
\hline Musa $\mathrm{x}$ paradisiaca $\mathrm{L}$. & Musaceae & silk fig & leaves & Paleotropical & $\mathrm{d}$ \\
\hline
\end{tabular}


APPENDIX III-A (continued)

\begin{tabular}{|c|c|c|c|c|c|}
\hline Scientific Name & Family Name $^{1}$ & Local Name(s) & Plant Part & Native Range $^{2}$ & Sources Cited \\
\hline $\begin{array}{l}\text { Neurolaena lobata (L.) R.Br. ex } \\
\text { Cass. }\end{array}$ & Asteraceae & $\begin{array}{l}\text { zeb-a-pik/ } \\
\text { zebapique }\end{array}$ & leaves & Neotropical & $\mathrm{c}, \mathrm{g}$ \\
\hline Passiflora quadrangularis L. & Passifloraceae & $\begin{array}{l}\text { barbadine/ } \\
\text { granadilla }\end{array}$ & leaves & Neotropical & $\mathrm{g}$ \\
\hline Persea americana Mill. & Lauraceae & zaboca/avocado & seed & Neotropical & $\mathrm{f}$ \\
\hline $\begin{array}{l}\text { Phyllanthus amarus Schumach. \& } \\
\text { Thonn. }\end{array}$ & Phyllanthaceae & seed-under-leaf & not specified & Neotropical & $\mathrm{c}$ \\
\hline Phyllanthus urinaria $\mathrm{L}$. & Phyllanthaceae & seed-under-leaf & not specified & Paleotropical & a \\
\hline $\begin{array}{l}\text { Pityrogramma calomelanos (L.) } \\
\text { Link }\end{array}$ & Pteridaceae & stamp fern & whole plant & Neotropical & e \\
\hline Ruellia tuberosa L. & Acanthaceae & minny root & root, leaves & Neotropical & $\mathrm{d}, \mathrm{e}$ \\
\hline Scoparia dulcis L. & Plantaginaceae & sweet broom & whole herb & Neotropical & $\mathrm{g}$ \\
\hline $\begin{array}{l}{ }^{3} \text { Senna fruticosa (Mill.) H.S. } \\
\text { Irwin \& Barneby }\end{array}$ & Fabaceae & christmas bush & flowers & Neotropical & $\mathrm{g}$ \\
\hline${ }^{3}$ Senna italica Mill. & Fabaceae & senna & not specified & $\begin{array}{l}\text { Paleotropical \& } \\
\text { Paleo-Temperate }\end{array}$ & $\mathrm{c}$ \\
\hline Spermacoce verticillata $\mathrm{L}$. & Rubiaceae & white head broom & whole herb & Neotropical & $\mathrm{g}$ \\
\hline
\end{tabular}


APPENDIX III-A (continued)

\begin{tabular}{|c|c|c|c|c|c|}
\hline Scientific Name & Family Name $^{1}$ & Local Name(s) & Plant Part & Native Range $^{2}$ & Sources Cited \\
\hline Spiranthes acaulis (Sm.) Cogn. & Orchidaceae & lapsogen & not specified & Neotropical & $\mathrm{a}$ \\
\hline Spondias mombin L. & Anacardiaceae & hog plum & leaves & Neotropical & $\mathrm{e}$ \\
\hline $\begin{array}{l}\text { Stachytarpheta jamaicensis (L.) } \\
\text { Vahl }\end{array}$ & Verbenaceae & vervine/ vervain & not specified & Neotropical & $\mathrm{c}$ \\
\hline
\end{tabular}

List of Historical sources by letter: (a) Lans 2001; (b) Mahabir 1991; (c) Mahabir \& Gulliford 1997; (d) Seaforth et al. 1983; (e) Seaforth et al. 1998; (f) Simpson 1962; (g) Wong 1976

1. Listing of Family names reflects information from the Angiosperm Phylogeny Group (Stevens 2011) and The Plant List (2016) websites.

2. Native ranges sourced from USDA GRIN Taxonomy for Plants (GRIN 2016) and Tropicos (2016) online databases

3. Originally listed as Cassia spp, these species have been assigned to the genus Senna based on shared floral morphology as described in Irwin and Barneby 1982. 
APPENDIX III-B - List of 30 plants cited as antidiabetic remedies in post-2000 literature in T\&T

\begin{tabular}{|c|c|c|c|c|c|}
\hline Scientific Name & Family Name $^{1}$ & Local Name & Plant Part & Native Range $^{2}$ & \# Citations \\
\hline $\begin{array}{l}\text { Antigonon leptopus Hooker \& } \\
\text { Arn. }\end{array}$ & Polygonaceae & coralita & $\begin{array}{l}\text { vine (stem and } \\
\text { leaves) }\end{array}$ & Neotropical & 1 \\
\hline Azadirachta indica A. Juss & Meliaceae & neem & leaves & Paleotropical & 7 \\
\hline Bidens pilosa $\mathrm{L}$. & Asteraceae & $\begin{array}{l}\text { railway daisy, } \\
\text { rabbit grass, } \\
\text { needle grass }\end{array}$ & leaves & Neotropical & 2 \\
\hline Bixa orellana $\mathrm{L}$. & Bixaceae & roucou & $\begin{array}{l}\text { leaves, fruits } \\
\text { and roots }\end{array}$ & Neotropical & 4 \\
\hline Bontia daphnoides $\mathrm{L}$. & Scrophulariaceae & olive bush & leaves & Neotropical & 2 \\
\hline $\begin{array}{l}\text { Bryophyllum pinnatum (Lam.) } \\
\text { Oken }\end{array}$ & Crassulaceae & $\begin{array}{l}\text { wonder of the } \\
\text { world }\end{array}$ & leaves & Paleotropical & 5 \\
\hline Carica papaya L. & Caricaceae & pawpaw & leaves & Neotropical & 2 \\
\hline Catharanthus roseus (L.) G. Don & Apocynaceae & $\begin{array}{l}\text { periwinkle / old } \\
\text { maid }\end{array}$ & $\begin{array}{l}\text { leaves and } \\
\text { flowers }\end{array}$ & Paleotropical & 7 \\
\hline Cecropia peltata $\mathrm{L}$. & Urticaceae & bois cano & leaves (dried) & Neotropical & 1 \\
\hline $\begin{array}{l}\text { Cheilocostus speciosus (I. Koenig } \\
\text { C.D.Specht) }\end{array}$ & Zingiberaceae & cane riviere & stem & Paleotropical & 1 \\
\hline
\end{tabular}


APPENDIX III-B - (continued)

\begin{tabular}{|c|c|c|c|c|c|}
\hline Scientific Name & Family Name $^{1}$ & Local Name & Plant Part & Native Range $^{2}$ & \# Citations \\
\hline Crescentia cujete L. & Bignoniaceae & calabash & leaves & Neotropical & 1 \\
\hline $\begin{array}{l}\text { Dolichandra unguis-cati (L.) L.G. } \\
\text { Lohmann }\end{array}$ & Bignoniaceae & cat's claw & stem and leaves & Neotropical & 1 \\
\hline Eclipta prostrata (L.) L. & Asteraceae & congolalla & stem and leaves & Neotropical & 2 \\
\hline Genipa americana $\mathrm{L}$. & Rubiaceae & monkey apple & fruit & Neotropical & 1 \\
\hline Gomphrena globosa L. & Amaranthaceae & $\begin{array}{l}\text { white bachelor } \\
\text { button }\end{array}$ & flowers & Neotropical & 1 \\
\hline Hibiscus rosa-sinensis $\mathrm{L}$. & Malvaceae & $\begin{array}{l}\text { double hibiscus, } \\
\text { arahoo }\end{array}$ & flowers & Paleotropical & 1 \\
\hline Leonotis nepetifolia (L.) R.Br. & Lamiaceae & shandilay & leaves & Paleotropical & 1 \\
\hline Lippia alba (Mill.) N.E.Br. & Verbenaceae & santa maria & leaves & Neotropical & 1 \\
\hline Mimosa pudica $\mathrm{L}$. & Fabaceae & $\begin{array}{l}\text { ti marie, shame } \\
\text { bush, sensitive } \\
\text { plant }\end{array}$ & whole plant & Neotropical & 1 \\
\hline Momordica charantia L. & Cucurbitaceae & caraille & $\begin{array}{l}\text { vine (stem and } \\
\text { leaves }\end{array}$ & Paleotropical & 7 \\
\hline Morinda citrifolia $\mathrm{L}$. & Rubiaceae & noni, pain bush & ripe fruit & Paleotropical & 1 \\
\hline
\end{tabular}


APPENDIX III-B - (continued)

\begin{tabular}{|c|c|c|c|c|c|}
\hline Scientific Name & Family Name $^{1}$ & Local Name & Plant Part & Native Range $^{2}$ & \# Citations \\
\hline $\begin{array}{l}\text { Neurolaena lobata (L.) R.Br. ex } \\
\text { Cass. }\end{array}$ & Asteraceae & zebapique & leaves & Neotropical & 2 \\
\hline Parthenium hysterophorus L. & Asteraceae & white top & leaves & Neotropical & 1 \\
\hline $\begin{array}{l}\text { Phyllanthus amarus Schumach \& } \\
\text { Thonn }\end{array}$ & Phyllanthaceae & $\begin{array}{l}\text { seed-under-leaf/ } \\
\text { guen amber faye }\end{array}$ & $\begin{array}{l}\text { whole plant } \\
\text { (stem, leaves } \\
\text { and roots) }\end{array}$ & Neotropical & 6 \\
\hline Piper tuberculatum Jacq. & Piperaceae & candle bush & leaves & Neotropical & 1 \\
\hline Rhipsalis baccifera & Cactaceae & old man beard & stem and leaves & Pantropical & 3 \\
\hline Spermacoce verticillata $\mathrm{L}$. & Rubiaceae & $\begin{array}{l}\text { white top, fowl } \\
\text { foot grass }\end{array}$ & leaves & Neotropical & 1 \\
\hline Tamarindus indica $\mathrm{L}$. & Fabaceae & tambran & bark & Paleotropical & 1 \\
\hline Tournefortia hirsutissima L. & Boraginaceae & jigger bush & stem and leaves & Neotropical & 1 \\
\hline Vernonia amygdalina Delile & Asteraceae & africana & leaves & Paleotropical & 1 \\
\hline
\end{tabular}

1. Listing of Family names reflects information from the Angiosperm Phylogeny Group (Stevens 2011) and The Plant List (2016) websites.

2. Native ranges sourced from USDA GRIN Taxonomy for Plants (GRIN 2016) and Tropicos (2016) online databases 
APPENDIX III-C - List of 46 antidiabetic remedies cited by community participants in field surveys in T\&T

\begin{tabular}{|c|c|c|c|c|c|}
\hline Scientific Name & Family Name $^{1}$ & Local Name & Plant Part & Native Range $^{2}$ & \# Citations \\
\hline Annona squamosa $\mathrm{L}$. & Annonaceae & sugar apple & $\begin{array}{l}\text { seeds ( } \\
\text { powdered) }\end{array}$ & Neotropical & 1 \\
\hline Aristolochia rugosa Lam. & Aristolochiaceae & $\begin{array}{l}\text { matroot / bitter } \\
\text { root / annico root }\end{array}$ & roots & Neotropical & 3 \\
\hline $\begin{array}{l}\text { Artocarpus altilis (Parkinson ex } \\
\text { F.A.Zorn) Fosberg }\end{array}$ & Moraceae & breadfruit & leaves (yellow) & Paleotropical & 2 \\
\hline Averrhoa carambola $\mathrm{L}$. & Oxalidaceae & five fingers & fruit & Paleotropical & 1 \\
\hline Azadirachta indica A. Juss & Meliaceae & neem & leaves & Paleotropical & 4 \\
\hline Bidens pilosa $\mathrm{L}$. & Asteraceae & railway daisy & not specified & Neotropical & 1 \\
\hline Bixa orellana $\mathrm{L}$. & Bixaceae & roucou & roots & Neotropical & 1 \\
\hline Bontia daphnoides $\mathrm{L}$. & Scrophulariaceae & olive bush & $\begin{array}{l}\text { leaves with } \\
\text { young floral } \\
\text { bud }\end{array}$ & Neotropical & 1 \\
\hline $\begin{array}{l}\text { Bryophyllum pinnatum (Lam.) } \\
\text { Oken }\end{array}$ & Crassulaceae & $\begin{array}{l}\text { wonder of the } \\
\text { world }\end{array}$ & leaves (raw) & Paleotropical & 2 \\
\hline Cannabis sativa L. & Cannabaceae & marijuana & leaves & Paleo-Temperate & 1 \\
\hline
\end{tabular}


APPENDIX III-C - (continued)

\begin{tabular}{|c|c|c|c|c|c|}
\hline Scientific Name & Family Name $^{1}$ & Local Name & Plant Part & Native Range $^{2}$ & \# Citations \\
\hline Capraria biflora $\mathrm{L}$. & Scrophulariaceae & ditay payee & not specified & Neotropical & 1 \\
\hline Catharanthus roseus (L.) G. Don & Apocynaceae & $\begin{array}{l}\text { periwinkle / old } \\
\text { maid }\end{array}$ & $\begin{array}{l}\text { flowers (white } \\
\text { variety } \\
\text { preferred) }\end{array}$ & Paleotropical & 6 \\
\hline Cecropia peltata $\mathrm{L}$. & Urticaceae & bois cano & leaves & Neotropical & 1 \\
\hline Cinnamomum sp. & Lauraceae & cinnamon & bark and leaf & Paleotropical & 3 \\
\hline Citrus paradisi Macfad. & Rutaceae & grapefruit & $\begin{array}{l}\text { fruit } \\
\text { (immature) }\end{array}$ & Neotropical Hybrid & 1 \\
\hline $\begin{array}{l}{ }^{5} \text { Cnidoscolus aconitifolius (Mill.) } \\
\text { I. M. Johnst. }\end{array}$ & Euphorbiaceae & chaya & leaves & Neotropical & 1 \\
\hline Cocos nucifera $\mathrm{L}$. & Arecaceae & coconut & $\begin{array}{l}\text { fruit (immature } \\
\text { - skin) }\end{array}$ & Paleotropical & 1 \\
\hline $\begin{array}{l}\text { Colubrina arborescens (Mill.) } \\
\quad \text { Sarg. }\end{array}$ & Rhamnaceae & mauby & bark & Neotropical & 2 \\
\hline $\begin{array}{l}\text { Cordia curassavica (Jacq.) Roem. } \\
\quad \& \text { Schult. }\end{array}$ & Boraginaceae & black sage & not specified & Neotropical & 1 \\
\hline
\end{tabular}


APPENDIX III-C - (continued)

\begin{tabular}{|c|c|c|c|c|c|}
\hline Scientific Name & Family Name $^{1}$ & Local Name & Plant Part & Native Range $^{2}$ & \# Citations \\
\hline Cucumis sativus L. & Cucurbitaceae & cucumber & fruit & Paleotropical & 1 \\
\hline Cymbopogon citratus (DC) Stapf & Poaceae & fever grass & leaves & Paleotropical & 1 \\
\hline Eryngium foetidum $\mathrm{L}$. & Apiaceae & shado beni & not specified & Neotropical & 1 \\
\hline Gomphrena globosa L. & Amaranthaceae & bachelor button & not specified & Neotropical & 1 \\
\hline Jatropha curcas L. & Euphorbiaceae & white physic nut & leaves & Neotropical & 1 \\
\hline Justicia secunda Vahl. & Acanthaceae & blood bush & not specified & Neotropical & 1 \\
\hline Laportea aestuans (L.) Chew & Urticaceae & stinging nettle & $\begin{array}{l}\text { roots (soaked } \\
\text { in vermouth) }\end{array}$ & Pantropical & 1 \\
\hline Mimosa pudica L. & Fabaceae & ti marie & $\begin{array}{l}\text { whole plant, } \\
\text { roots }\end{array}$ & Neotropical & 3 \\
\hline Momordica charantia $\mathrm{L}$. & Cucurbitaceae & caraaili/ corailee & leaves, fruit & Paleotropical & 9 \\
\hline Morinda citrifolia $\mathrm{L}$. & Rubiaceae & noni & $\begin{array}{l}\text { ripe fruit, } \\
\text { leaves }\end{array}$ & Paleotropical & 3 \\
\hline $\begin{array}{l}\text { Neurolaena lobata (L.) R.Br. ex } \\
\text { Cass. }\end{array}$ & Asteraceae & $\begin{array}{l}\text { zebapique/ } \\
\text { zebapip }\end{array}$ & leaves & Neotropical & 4 \\
\hline $\begin{array}{l}\text { Nopalea cochinellifera (L.) Salm- } \\
\text { Dyck }\end{array}$ & Cactaceae & ratchet & $\begin{array}{l}\text { fresh leaf pads } \\
\text { (blended) }\end{array}$ & Neotropical & 1 \\
\hline
\end{tabular}


APPENDIX III-C - (continued)

\begin{tabular}{|c|c|c|c|c|c|}
\hline Scientific Name & Family Name $^{1}$ & Local Name & Plant Part & Native Range $^{2}$ & \# Citations \\
\hline Paspalum vaginatum $\mathrm{Sw}$. & Poaceae & chien dent & leaves & Paleotropical & 2 \\
\hline Passiflora quadrangularis L. & Passifloraceae & barbadine & leaves (yellow) & Neotropical & 1 \\
\hline Peperomia pellucida (L.) Kunth. & Piperaceae & shining bush & whole plant & Neotropical & 1 \\
\hline Petroselinum crispum (Mill.) Fuss & Apiaceae & parsley & not specified & $\begin{array}{l}\text { Probably } \\
\text { Mediterranean }\end{array}$ & 1 \\
\hline $\begin{array}{c}{ }^{3} \text { Phaseolus vulgaris L. var. } \\
\text { vulgaris }\end{array}$ & Fabaceae & string bean & pods (fresh) & Neotropical & 2 \\
\hline Phyllanthus spp. & Phyllanthaceae & $\begin{array}{l}\text { seed-under-leaf/ } \\
\text { seeds-on-back/ } \\
\text { gwen amba fei }\end{array}$ & whole plant & $\begin{array}{l}\text { Neotropical and } \\
\text { Paleotropical } \\
\text { species }\end{array}$ & 7 \\
\hline $\begin{array}{l}\text { Pitryrogramma calomelanos (L.) } \\
\quad \text { Link }\end{array}$ & Pteridaceae & stamping fern & not specified & Neotropical & 1 \\
\hline Scoparia dulcis L. & Scrophulariaceae & sweet broom & not specified & Neotropical & 1 \\
\hline Spermacoce verticillata $\mathrm{L}$. & Rubiaceae & white head broom & whole plant & Neotropical & 1 \\
\hline Stachytarpheta jamaicensis L. & Verbenaceae & vervine & not specified & Neotropical & 1 \\
\hline Syzigium cumini (L.) Skeels & Myrtaceae & jamoon & leaves & Paleotropical & 1 \\
\hline
\end{tabular}


APPENDIX III-C - (continued)

\begin{tabular}{|c|c|c|c|c|c|}
\hline Scientific Name & Family Name $^{1}$ & Local Name & Plant Part & Native Range $^{2}$ & \# Citations \\
\hline Tamarindus indica $\mathrm{L}$. & Fabaceae & tambran & leaves, seed & Paleotropical & 2 \\
\hline $\begin{array}{l}{ }^{4} \text { Taraxacum officinale } \\
\quad \text { aggr. F.H.Wigg., Prim. }\end{array}$ & Asteraceae & dandelion & not specified & Pan-Temperate & 1 \\
\hline Urena lobata $\mathrm{L}$. & Malvaceae & koozay mahoe & not specified & Pantropical & 1 \\
\hline${ }^{5}$ Vernonia amygdalina Delile & Asteraceae & nigerian bitterleaf & leaves & Paleotropical & 1 \\
\hline
\end{tabular}

1. Listing of Family names reflects information from the Angiosperm Phylogeny Group (Stevens 2011) and The Plant List (2016) websites.

2. Native ranges sourced from USDA GRIN Taxonomy for Plants (GRIN 2016) and Tropicos (2016) online databases

3. The Plant List indicates that Phaseolus vulgaris L. var. vulgaris (as named by GRIN) is a synonym of the plant name Phaseolus vulgaris $\mathrm{L}$

4. Taraxacum officinale aggr. F.H.Wigg., Prim as listed in the MPNS resource is indicated as Taraxacum officinale (L.) Weber ex F.H.Wigg in the Plant List and is designated as a synonym of Taraxacum campylodes G.E.Haglund

5. Cultivated specimens imported by participant 
APPENDIX III-D - List of 51 antidiabetic remedies cited by herbalists in field surveys in T\&T

\begin{tabular}{|c|c|c|c|c|c|}
\hline Scientific Name & Family Name $^{1}$ & Local Name & Plant Part & Native Range $^{2}$ & \# Citations \\
\hline Allium cepa $\mathrm{L}$. & Amaryllidaceae & onion & not specified & Uncertain & 2 \\
\hline Allium sativum $\mathrm{L}$. & Amaryllidaceae & garlic & not specified & Paleo-Temperate & 3 \\
\hline Aloe vera (L.) Burm. f. & Xanthorrhoeaceae & aloe & not specified & Paleo-Temperate & 2 \\
\hline Alysicarpus vaginalis (L.) DC & Fabaceae & speed vine & whole plant & Paleotropical & 1 \\
\hline Ananas comosus (L.) Merr. & Bromeliaceae & $\begin{array}{l}\text { pineapple (half- } \\
\text { ripe fruit) }\end{array}$ & fruit (half-ripe) & Neotropical & 1 \\
\hline Apium graveolens $\mathrm{L}$. & Apiaceae & celery & not specified & Paleo-Temperate & 1 \\
\hline $\begin{array}{l}\text { Arctostaphylos uva-ursi (L.) } \\
\text { Spreng. }\end{array}$ & Ericaceae & uva ursi & not specified & Pan-Temperate & 2 \\
\hline Aristolochia rugosa Lam. & Aristolochiaceae & matroot & root & Neotropical & 1 \\
\hline $\begin{array}{l}\text { Artocarpus altilis (Parkinson) } \\
\text { Fosberg }\end{array}$ & Moraceae & breadfruit & not specified & Paleotropical & 1 \\
\hline Avena sativa $\mathrm{L}$. & Poaceae & oats & not specified & Uncertain & 1 \\
\hline Azadirachta indica $\mathrm{L}$. & Meliaceae & neem & leaf tea, oil & Paleotropical & 4 \\
\hline Bambusa vulgaris Schrad. & Poaceae & bamboo grass, & not specified & Paleotropical & 1 \\
\hline
\end{tabular}


APPENDIX III-D - (continued)

\begin{tabular}{|c|c|c|c|c|c|}
\hline Scientific Name & Family Name $^{1}$ & Local Name & Plant Part & Native Range $^{2}$ & \# Citations \\
\hline Bauhinia guianensis Aubl. & Fabaceae & $\begin{array}{l}\text { monkey step (aka } \\
\text { granny backbone) }\end{array}$ & woody vine & Neotropical & 1 \\
\hline Brassica oleracea L. var italica & Brassicaceae & broccoli & not specified & Paleo-Temperate & 1 \\
\hline $\begin{array}{l}\text { Brassica rapa } \mathrm{L} . \\
\quad \text { subsp. chinensis (L.) Hanelt }\end{array}$ & Brassicaceae & pak choy & not specified & Paleo-Temperate & 1 \\
\hline Carica papaya L. & Caricaceae & $\begin{array}{l}\text { paw paw (green } \\
\text { fruit) }\end{array}$ & fruit (green) & Neotropical & 1 \\
\hline Catharanthus roseus (L.) G.Don & Apocynaceae & periwinkle & flowers & Paleotropical & 2 \\
\hline Cecropia peltata $\mathrm{L}$. & Urticaceae & bois canot & not specified & Neotropical & 1 \\
\hline $\begin{array}{c}\text { Chromolaena odorata (L.) } \\
\text { R.M.King \& H.Rob }\end{array}$ & Asteraceae & christmas bush & not specified & Neotropical & 1 \\
\hline Cinnamomum sp. & Lauraceae & cinnamon & bark (powder) & Paleotropical & 4 \\
\hline Cocos nucifera $\mathrm{L}$. & Arecaceae & coconut (dry) & nut (dried) & Paleotropical & 1 \\
\hline $\begin{array}{l}\text { Colubrina arborescens (Mill.) } \\
\text { Sarg. }\end{array}$ & Rhamnaceae & mauby & bark & Neotropical & 1 \\
\hline Cucurbita pepo L. & Cucurbitaceae & $\begin{array}{l}\text { pumpkin seed } \\
\text { extract }\end{array}$ & seeds & Neo-Temperate & 1 \\
\hline
\end{tabular}


APPENDIX III-D - (continued)

\begin{tabular}{|c|c|c|c|c|c|}
\hline Scientific Name & Family Name $^{1}$ & Local Name & Plant Part & Native Range $^{2}$ & \# Citations \\
\hline Curcuma longa $\mathrm{L}$. & Zingiberaceae & turmeric & rhizome & Paleotropical & 1 \\
\hline Foeniculum vulgare Mill., Gard. & Apiaceae & fennel & not specified & Paleo-Temperate & 1 \\
\hline Galega officinalis L. & Fabaceae & goats' rue & not specified & Paleo-Temperate & 1 \\
\hline Gentiana sp. & Gentianaceae & gentian (rt.) & not specified & Uncertain & 1 \\
\hline Glycyrrhiza glabra $\mathrm{L}$. & Fabaceae & licorice & not specified & Paleo-Temperate & 1 \\
\hline $\begin{array}{l}\text { Gymnema sylvestre (Retz.) R.Br. } \\
\quad \text { ex Sm. }\end{array}$ & Apocynaceae & gymnema & not specified & Paleotropical & 7 \\
\hline Hamelia patens Jacq. & Rubiaceae & wild clover & leaves & Neotropical & 1 \\
\hline Hydrastis canadensis $\mathrm{L}$. & Ranunculaceae & golden seal & not specified & Neo-Temperate & 2 \\
\hline Juniperus communis L. & Cupressaceae & juniper berries & fruit & Pan- Temperate & 1 \\
\hline $\begin{array}{l}\text { Larrea tridentata (Sessé \& Moc. } \\
\quad \text { ex DC.) Coville }\end{array}$ & Zygophyllaceae & chaparral & not specified & Neo-Temperate & 1 \\
\hline Momordica charantia L. & Cucurbitaceae & $\begin{array}{l}\text { carailli or bitter } \\
\text { melon }\end{array}$ & leaves, fruit & Paleotropical & 7 \\
\hline Neurolaena lobata (L.) Cass. & Asteraceae & zebapique & leaves & Neotropical & 1 \\
\hline Olea europaea L. & Oleaceae & olive oil & oil & Paleotemperate & 1 \\
\hline
\end{tabular}


APPENDIX III-D - (continued)

\begin{tabular}{|c|c|c|c|c|c|}
\hline Scientific Name & Family Name $^{1}$ & Local Name & Plant Part & Native Range $^{2}$ & \# Citations \\
\hline Petroselinum crispum (Mill.) Fuss & Apiaceae & parsley & leaves & $\begin{array}{l}\text { Probably } \\
\text { Mediterranean }\end{array}$ & 2 \\
\hline $\begin{array}{l}{ }^{3} \text { Phaseolus vulgaris L. var. } \\
\text { vulgaris }\end{array}$ & Fabaceae & string beans & pod (fresh) & Neotropical & 2 \\
\hline Phyllanthus spp. & Phyllanthaceae & seed-under-leaf & not specified & $\begin{array}{l}\text { Neotropical \& } \\
\text { Paleotropical }\end{array}$ & 2 \\
\hline Prunus dulcis (Mill.) D.A.Webb & Rosaceae & almonds & nuts & Paleo-Temperate & 1 \\
\hline Pterocarpus marsupium Roxb. & Fabaceae & $\begin{array}{l}\text { indian } \mathrm{k}[\mathrm{i}] \mathrm{no} / \mathrm{red} \\
\text { dragon blood }\end{array}$ & not specified & Paleotropical & 1 \\
\hline Rosmarinus officinalis $\mathrm{L}$. & Lamiaceae & rosemary & not specified & $\begin{array}{l}\text { Probably } \\
\text { Mediterranean }\end{array}$ & 2 \\
\hline Salvia officinalis $\mathrm{L}$. & Lamiaceae & sage & not specified & $\begin{array}{l}\text { Probably } \\
\text { Mediterranean }\end{array}$ & 1 \\
\hline Spermacoce verticillata $\mathrm{L}$. & Rubiaceae & white head broom & not specified & Neotropical & 1 \\
\hline $\begin{array}{l}\text { Stachytarpheta jamaicensis (L.) } \\
\text { Vahl }\end{array}$ & Verbenaceae & vervine & not specified & Neotropical & 2 \\
\hline $\begin{array}{l}\text { Stevia rebaudiana (Bertoni) } \\
\text { Bertoni }\end{array}$ & Asteraceae & stevia & not specified & Neotropical & 1 \\
\hline
\end{tabular}


APPENDIX III-D - (continued)

\begin{tabular}{|c|c|c|c|c|c|}
\hline Scientific Name & Family Name $^{1}$ & Local Name & Plant Part & Native Range $^{2}$ & \# Citations \\
\hline $\begin{array}{l}{ }^{4} \text { Taraxacum officinale } \\
\text { aggr. F.H.Wigg., Prim. }\end{array}$ & Asteraceae & dandelion & leaves, root & Pan-Temperate & 5 \\
\hline Trifolium pratense $\mathrm{L}$. & Fabaceae & red clover & not specified & Paleo-Temperate & 1 \\
\hline Trigonella foenum-graecum $\mathrm{L}$. & Fabaceae & fenugreek & not specified & Paleo-Temperate & 1 \\
\hline Verbascum sp. & Fabaceae & mullein & not specified & Paleo-Temperate ) & 1 \\
\hline Zingiber officinale Roscoe & Zingiberaceae & ginger & root & Paleotropical & 2 \\
\hline
\end{tabular}

1. Listing of Family names reflects information from the Angiosperm Phylogeny Group (Stevens 2011) and The Plant List (2016) websites.

2. Native ranges sourced from USDA GRIN Taxonomy for Plants (GRIN 2016) and Tropicos (2016) online databases

3. The Plant List indicates that Phaseolus vulgaris L. var. vulgaris (as named by GRIN) is a synonym of the plant name Phaseolus vulgaris L.

4. Taraxacum officinale aggr. F.H.Wigg., Prim as listed in the MPNS resource is indicated as Taraxacum officinale (L.) Weber ex F.H.Wigg in the Plant List and is designated as a synonym of Taraxacum campylodes G.E.Haglund 
VITA

\section{ANGELLE L. BULLARD-ROBERTS}

Born, Point Fortin, Republic of Trinidad and Tobago

1996

1997-1999

$1999-2000$

B.S. Biology

Andrews University Extension Campus

Caribbean Union College

(now University of the Southern Caribbean)

Maracas Valley, St. Joseph, Trinidad and Tobago

Administrative Assistant, Office of Academic Administration

Caribbean Union College

Maracas Valley, St. Joseph, Trinidad and Tobago

Instructor, Environmental Science (part-time)

Caribbean Union College

Maracas Valley, St. Joseph, Trinidad and Tobago

2000

M.S. Science and Management of Tropical Environments

University of the West Indies

St. Augustine Campus, Trinidad and Tobago

2000-2004

Instructor, Biology

Caribbean Union College

Maracas Valley, St. Joseph, Trinidad and Tobago

2004

2007-2011

Excellence in Teaching Award - Faculty of Natural Sciences

North American Alumni Association

Caribbean Union College

Graduate Teaching Assistant, Biology

Florida International University

Miami, Florida

2009

Field Research Grant

Explorer's Club of South Florida

2009

Tropical Botany Scholarship (Field Research)

Kelly Foundation

2009

Pre-dissertation Field Researcher

Medicinal Plants of Trinidad and Tobago

2011

Anne Chatham Fellowship in Medicinal Botany

Garden Club of America 
Doctoral Evidence Acquisition (DEA) Fellowship

University Graduate School

Florida International University

2011-2012

Dissertation Field Researcher

Medicinal Plants of Trinidad and Tobago

2011-2016

Ph.D. Candidate, Biology

Florida International University

Miami, Florida

2013-2015

Graduate Teaching Assistant, Biology

Florida International University

Miami, Florida

2014

Tropical Botany Scholarship (Lab Research)

Kelly Foundation

$2014-2016$

Dissertation Lab Researcher

Phenolic Content and Alpha-Glucosidase Inhibitory Activity of Medicinal Plants of Trinidad and Tobago

2015

$2^{\text {nd }}$ place Poster - Biology and Biochemistry Section, Graduate Student Scholarly Forum

\section{PRESENTATIONS}

Bullard-Roberts, A. L. and B.C. Bennett (July 2011). Treating Sugar: The Antidiabetic Remedies of Trinidad and Tobago (Oral Presentation). Joint Conference of Botanical Society of America and Society for Economic Botany, St. Louis, Missouri.

Bullard-Roberts, A. L. and B.C. Bennett (May 2014). From Bush Tea to Herbal Tea: Current Trends in the Medicinal Plant Trade in Trinidad and Tobago (Oral Presentation). $55^{\text {th }}$ Annual Meeting of the Society for Economic Botany, Cherokee, North Carolina.

Bullard-Roberts, A.L. and B.C. Bennett (April 2015). The Antidiabetic Properties of Medicinal Plants from Trinidad and Tobago (Poster Presentation). Graduate Student Scholarly Forum, Florida International University, Miami, Florida.

Bullard-Roberts, A.L. and B.C. Bennett (August 2016). Historical Ethnobotany of the Antidiabetic Remedies of Trinidad and Tobago: Knowledge Conservation or Innovation? (Oral Presentation). Botanical Society of America Conference, Savannah, Georgia. 